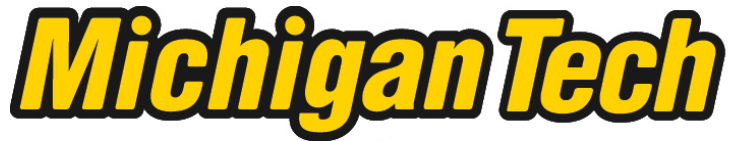 \\ Michigan Technological University Create the Future Digital Commons @ Michigan Tech
}

More favorable combination of circumstances could hardly have been desired : a bottom to top examination of the Pittsburgh and Boston Mining Company's Cliff Mine

Sean M. Gohman

Michigan Technological University

Follow this and additional works at: https://digitalcommons.mtu.edu/etds

Part of the Archaeological Anthropology Commons

Copyright 2010 Sean M. Gohman

Recommended Citation

Gohman, Sean M., "More favorable combination of circumstances could hardly have been desired : a bottom to top examination of the Pittsburgh and Boston Mining Company's Cliff Mine", Master's Thesis, Michigan Technological University, 2010.

https://doi.org/10.37099/mtu.dc.etds/296

Follow this and additional works at: https://digitalcommons.mtu.edu/etds

Part of the Archaeological Anthropology Commons 


\section{A MORE FAVORABLE COMBINATION OF CIRCUMSTANCES COULD HARDLY HAVE BEEN DESIRED: A BOTTOM TO TOP EXAMINATION OF THE PITTSBURGH AND BOSTON MINING COMPANY'S CLIFF MINE}

By

Sean M. Gohman

\section{A THESIS}

Submitted in partial fulfillment of the requirements for the degree of MASTER OF SCIENCE IN INDUSTRIAL ARCHAEOLOGY

MICHIGAN TECHNOLOGICAL UNIVERSITY

2010

(C) 2010 Sean M. Gohman 
This thesis, "A More Favorable Combination of Circumstances Could Hardly Have Been Desired: A Bottom to Top Examination of the Pittsburgh and Boston Mining Company's Cliff Mine" is hereby approved in partial fulfillment of the requirements for the Degree of MASTER OF SCIENCE IN INDUSTRIAL ARCHAEOLOGY.

DEPARTMENT:

Social Sciences

Signatures:

Department Chair/Thesis Advisor:

Dr. Patrick E. Martin

Committee Member:

Dr. Timothy J. Scarlett

Committee Member:

Dr. Michael Falkowski

Date: 


\begin{abstract}
The Cliff Mine, an archaeological site situated on the Keweenaw Peninsula of Michigan, is the location of the first successful attempt to mine native copper in North America. Under the management of the Pittsburgh \& Boston Mining Company from 1845-1879, two-third of the Cliff's mineral output was in the form of mass copper, some pieces of which weighed over 5 tons when removed from the ground. The unique nature of mass copper and the Cliff Mine's handling of it make it one of the best examples of early mining processes in the Keweenaw District. Mass copper only constituted $2 \%$ of the entire product of the Lake Superior copper districts, and the story of early mining on the Peninsula is generally overshadowed by later, longer running mines such as the Calumet \& Helca and Quincy Mining Companies. Operating into the mid-twentieth century, the size and duration of these later mines would come to define the region, though they would not have been possible without the Cliff's early success.

Research on the Cliff Mine has previously focused on social and popular history, neglecting the structural remains. However, these remains are physical clues to the technical processes that defined early mining on the Keweenaw. Through archaeological investigations, these processes and their associated networks were documented as part of the 2010 Michigan Technological Archaeology Field School's curriculum. The project will create a visual representation of these processes utilizing Geographic Information Systems software. This map will be a useful aid in future research, community engagement and possible future interpretive planning.
\end{abstract}




\section{Acknowledgements}

This thesis would not have been possible without the assistance of a number of individuals and organizations. I would first like to thank my advisor, Dr. Patrick E. Martin, and committee members, Dr. Timothy J. Scarlett and Dr. Michael J. Falkowski for their advice, direction, and guidance during this project. I am grateful to the Keweenaw County Road Commission, owners of the Cliff Mine site, for giving me permission to work at the site and signing off on a grant proposal for the project's funding. I am also indebted to the grantor of that funding, the Keweenaw National Historic Park's Advisory Commission, and am thankful for the KNHP's support of my interest in the Cliff Mine. Also, thanks must be given to Joseph R. Dancy and LSGI Technology Venture Fund L.P. for their generous gifts to the project.

My research would have gone nowhere without the assistance of the Michigan Tech Archives and Copper Country Historical Collection. Erik Nordberg, Julia Blair, Christine Holland, and the rest of the staff were always extremely helpful in opening up new avenues of inquiry. Thanks also to the faculty of the Michigan Technological University's Department of Social Sciences and Industrial Archaeology program, especially Sam Sweitz, Larry Lankton, and Susan Martin. Thanks also to the 2010 field crew: Steve Moray, Jessica Posega, Lisa Gillis, Jim Dau, William Deephouse, John Baeten, Mark Dice, Sawyer Newman, and Kim Barton, as well as my fellow students in the Industrial Archaeology program (past and present): Jessica Montcalm, Chris Nelson, Tim Goddard, Elizabeth Norris, Bode Morin, and Cameron Hartnell. I would like to point out three individuals in particular for their assistance: Paul White for showing me how to look at mining landscapes, Seth DePasqual for introducing me to the Cliff, and Craig Wilson for acting as a sound board (and voice of reason) during all my forays into rampant speculation regarding the mine.

Last but not least I would like to thank the people of the Keweenaw and Copper Country for their continued support of this project. Knowing that there is a growing interest in the Cliff Mine (and Keweenaw mining in general) gives me the drive to keep moving forward in this research. I appreciate what the Keweenaw has given me and I hope I can give something back to it. 


\section{Table of Contents}

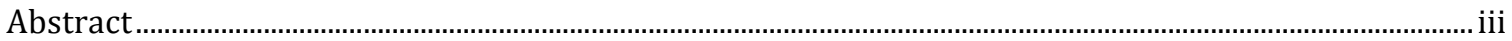

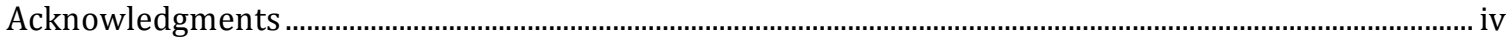

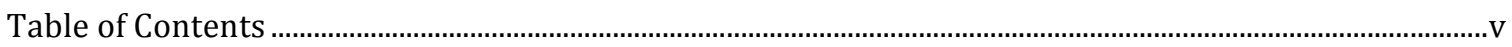

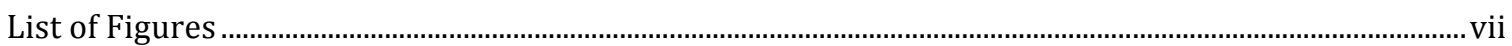

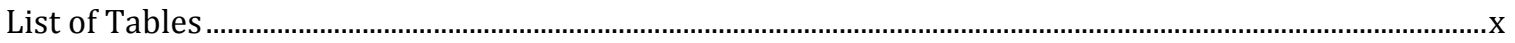

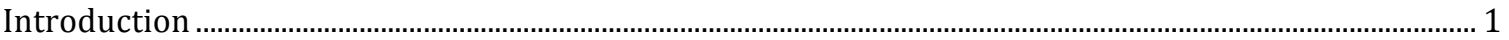

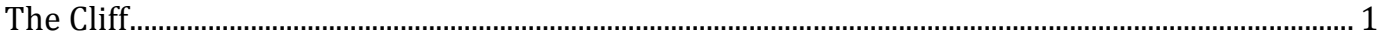

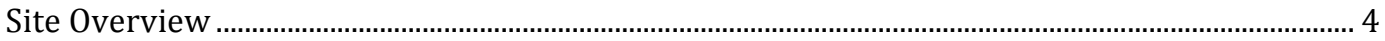

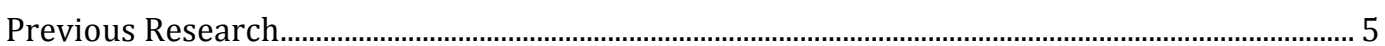

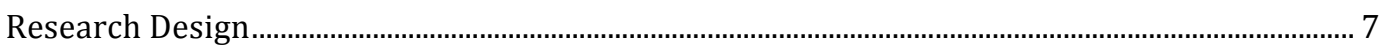

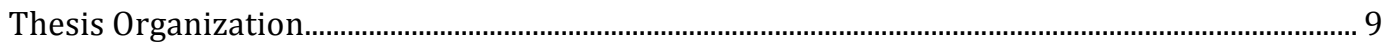

Chapter 1: Historical Context for Native Copper Mining in Lake Superior ..................................................11

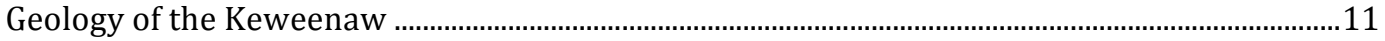

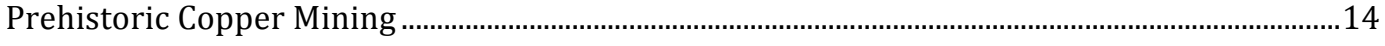

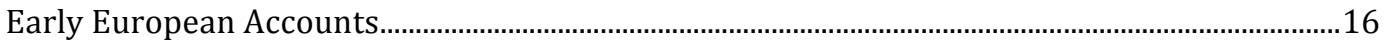

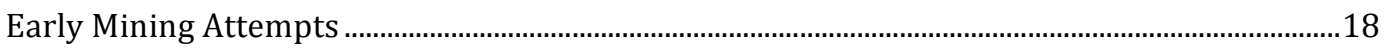

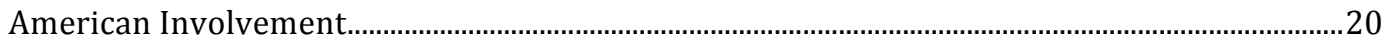

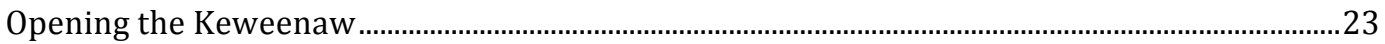

The Pittsburgh and Boston Copper Harbor Mining Company .............................................................28

Lease 4: The Workings at Copper Harbor ........................................................................................32

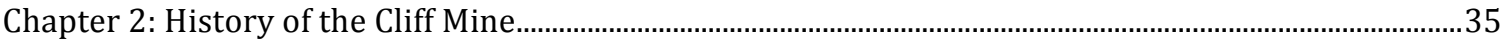

Lease 5: The Discovery of the Cliff Vein ….....................................................................................35

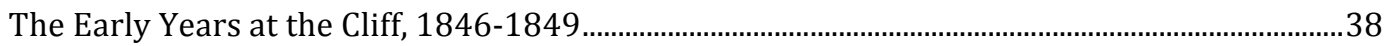

Early Mining Practice in the Keweenaw: Working Underground ......................................................42

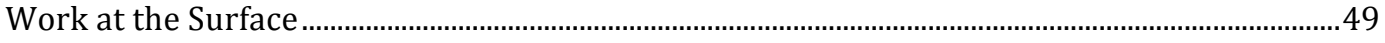

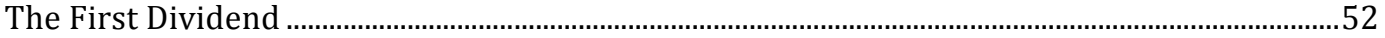

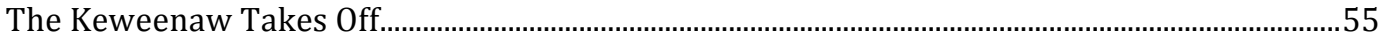

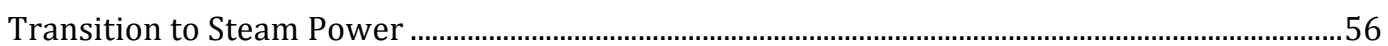

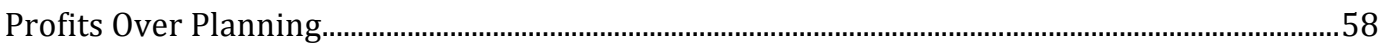

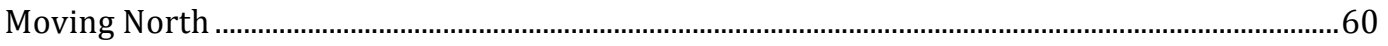

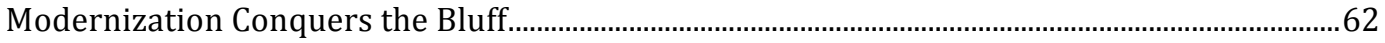

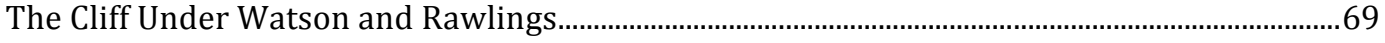

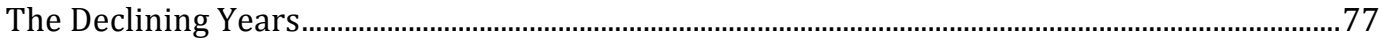




\section{Table of Contents, Cont.}

The Cliff Copper Company and Calumet \& Hecla Periods ........................................................................

Chapter 3: Fieldwork and Documentation .......................................................................................................

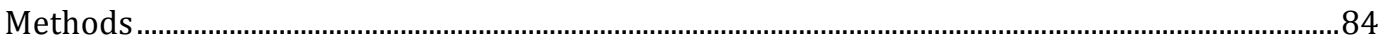

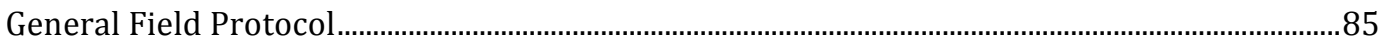

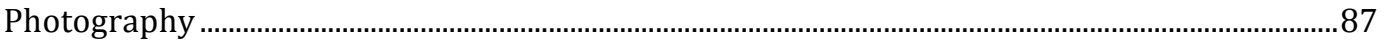

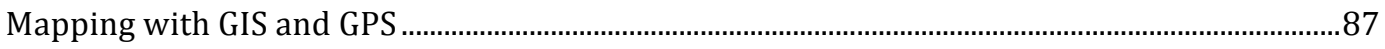

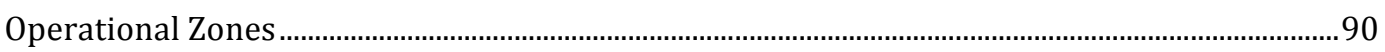

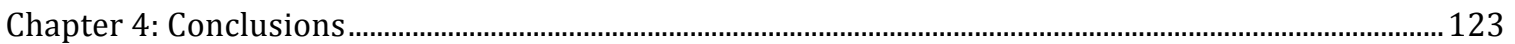

Distinct Periods in the Mine's Development ....................................................................................... 124

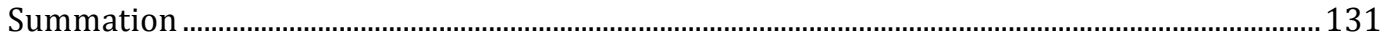

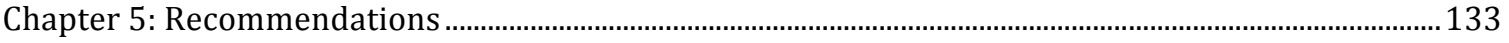

Directions for Further Research: Historical Sources ........................................................................133

Directions for Further Research: Archaeology ……………………………………………………... 135

Preservation and Public Interpretation .........................................................................................136

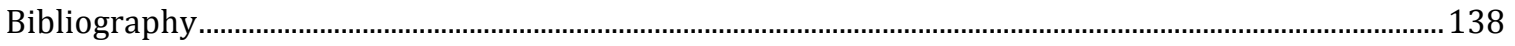

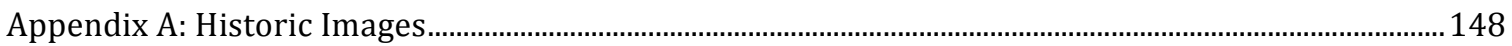

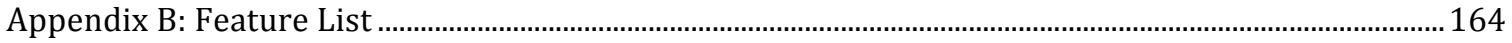




\section{List of Figures}

I-1. Robert F. Duncanson's “Cliff Mine, Lake Superior” 1848 ........................................

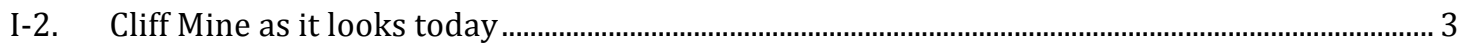

1-1. View of Cliff Mine and Clifton, summer 2009 …..........................................................................11

1-2. Charles Whittlesey’s “Outline Map Showing the Position of Ancient Mine Pits of Point

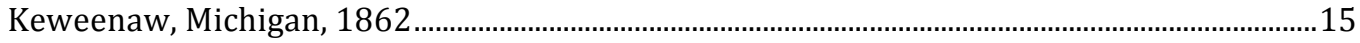

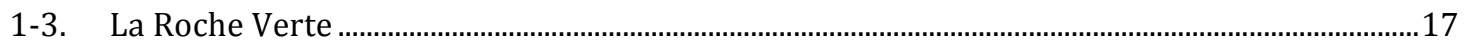

1-4. Engraving of Cass Expedition to the Ontonagon Boulder ...........................................................22

1-5. Map showing the 1842 Boundaries drawn by the Treaty of La Pointe......................................22

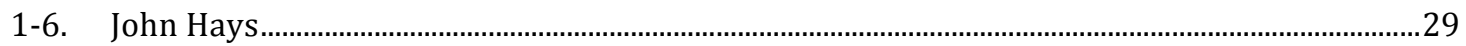

1-7. Map of Mineral Leases on the Keweenaw Peninsula .....................................................................

1-8. Detail of Location No. 4 from the Geological Survey of the Mineral Lands on the Southern Shore of Lake Superior Belonging to the Pittsburgh and Boston Copper Harbor Mining

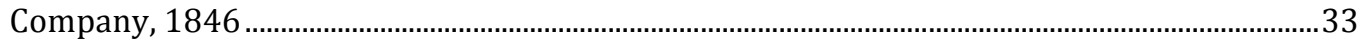

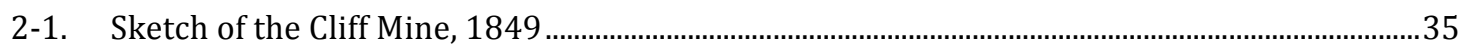

2-2. Sam W. Hill's, Topographical and Underground Plan of the Cliff Mine Situated on Keweenaw Point, for Charles T. Jackson, U.S. Geologist, 1847 ....................................................40

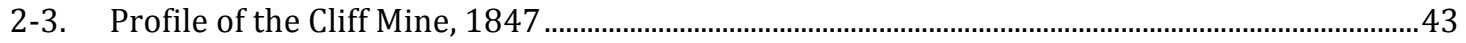

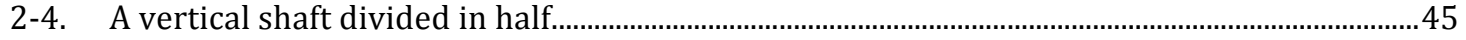

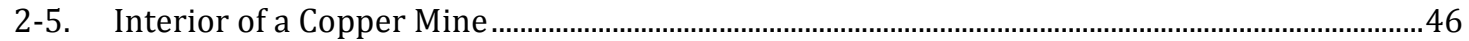

2-6. Cliff Mine underground drawing from Foster and Whitney's, Report on the Geology and Topography of a Portion of the Lake Superior Land District .......................................................4 48

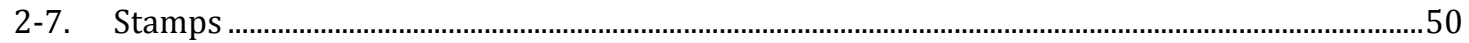

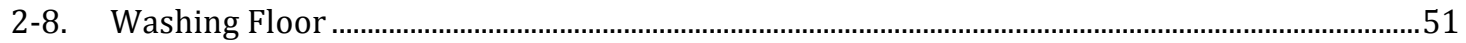

2-9. Samuel Hodge's ore crushing machine

2-10. American High Pressure Engine

2-11. Lands Belonging to the Pittsburgh and Boston Mining Company (Cliff Mine), April, 1862 ..68

2-12. George Asmus' Machine for Separating or Cleaning Ores.............................................................74

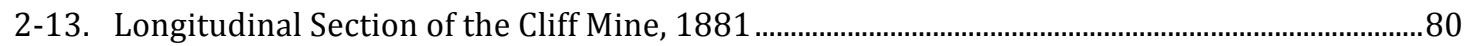

3-1. Panoramic View of Cliff Mine and Townsite of Clifton, 1906 ......................................................84

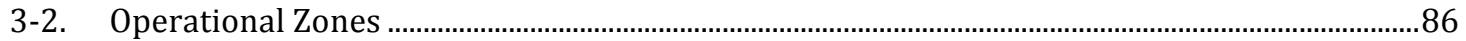

3-3. Overview of Cliff Mine Industrial Core (GIS) .............................................................................90

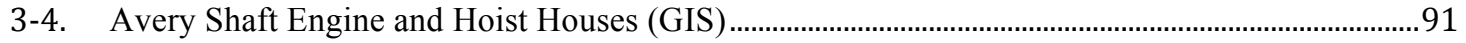

3-5. Avery Shaft Engine and Hoist House profile drawing.........................................................................92

3-6. Fea.AV.304: Avery Shaft Engine House Boiler Room, from north.................................................94

3-7. Fea.AV.305: Avery Shaft Engine House Smoke Stack .....................................................................94

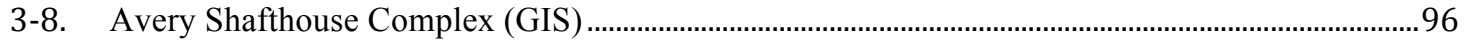


3-9. Fea.AV.313: Avery Shafthouse Possible Entrance ………………………………………………......97

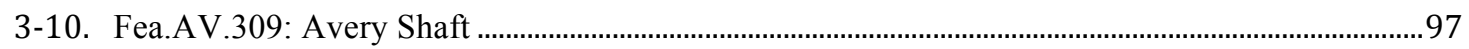

3-11. Machine Shop and Wagon Road (GIS) ………….......................................................................

3-12. Mineral House (GIS) ....................................................................................................................... 100

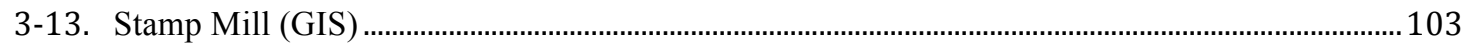

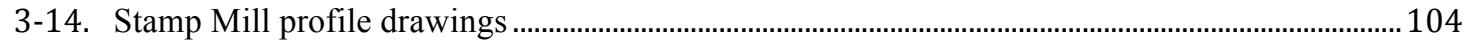

3-15. Fea.SM.102: Stamp Mill's Boiler Room, from east ………………………….................................. 105

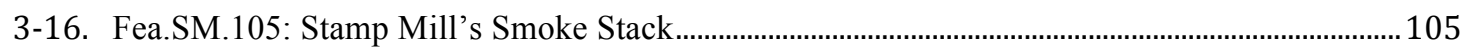

3-17. Fea.SM.104: Stamp Mill's Raised Platform, from south .....................................................................108

3-18. Fea.SM.104: Stone and Brick Pedestal ……………............................................................................ 108

3-19. Fea.N3.400: No. 3 Shaft Engine and Hoist House (GIS) ................................................................... 109

3-20. Fea.N3.400: No. 3 Shaft Engine and Hoist House Boiler and Engine Rooms .............................. 112

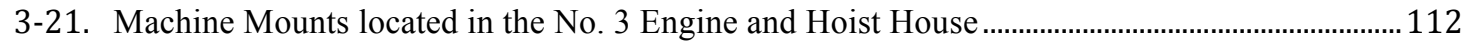

3-22. Fea.N3.402: No. 3 Shaft...............................................................................................................113

3-23. Howe Shaft Engine and Hoist House (GIS) ............................................................................... 114

3-24. Fea.N4.500: Howe Shaft Engine and Hoist House, from southwest..................................................116

3-25. Fea.N4.501: Howe Shaft Smoke Stack ………………………………………………………………....116

3-26. Detail of possible date stamp on Howe Shaft Smoke Stack................................................................116

3-27. Fea.N4.500: Howe Shaft Engine and Hoist House Boiler Room, from south ..............................117

3-28. Fea.N4.500: Howe Shaft Engine and Hoist House, from north ...................................................... 117

3-29. Fea.N4.503: Howe Shaft Kiln/Rock House ...................................................................................... 120

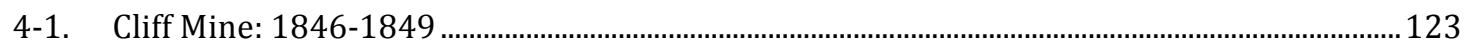

4-2. Cliff Mine: 1850-1855 ...................................................................................................... 125

4-3. Cliff Mine: 1856-1860 …………………………..................................................................

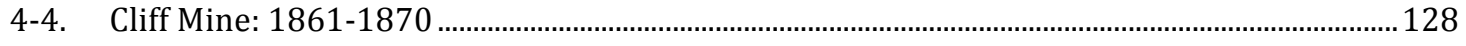

5-1. View south from the Cliff Bluff, 2009 .......................................................................................... 133 


\section{List of Figures, Cont.}

A-1. Avery Shaft surface plant from south, circa 1857 ……............................................................119

A-2. Avery Shaft surface plant from west, circa 1896 .........................................................................120

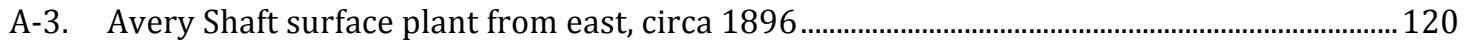

A-4. Avery Shaft surface plant from the south, circa 1900 …….......................................................121

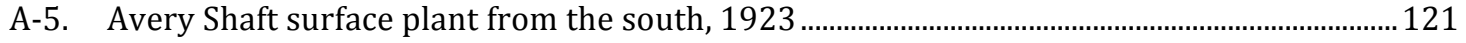

A-6. Collapsed Avery Shaft, circa 1905

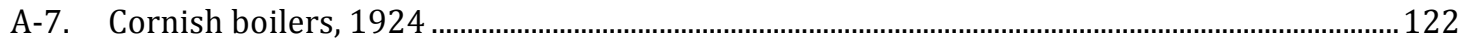

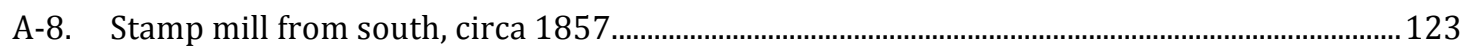

A-9. Stamp mill and Avery Shaft surface plant with rock chute visible, 1862 ................................123

A-10. Stamp mill from south, detail of wash house, circa 1880's-1890's ...........................................124

A-11. Stamp mill from NW (reuse period), showing South Cliff No. 1, circa 1906.............................124

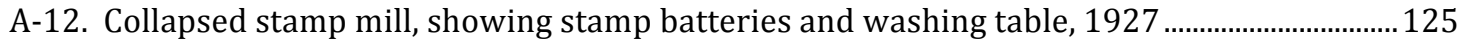

A-13. Stamp mill interior showing stamp batteries (reuse period), taken 1926 .................................125

A-14. Howe Shaft engine/hoist house, from SW, circa 1860's -1890's ..............................................126

A-15. Howe Shaft engine/hoist house, kiln house, and shaft house, from east, circa 1870's-1890's

A-16. Howe Shaft engine/hoist house and kiln house remains, with vertical rotative engine

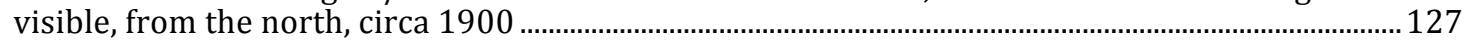

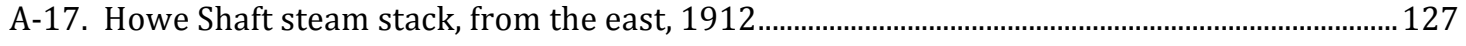

A-18. Cliff mine and Clifton panoramic view from the NW, circa 1930's .............................................128

A-19. School and Mine Office buildings from the west, 1925 ...............................................................128

A-20. Clifton from west (Superintendent's House), focused on road, 1906 .......................................129

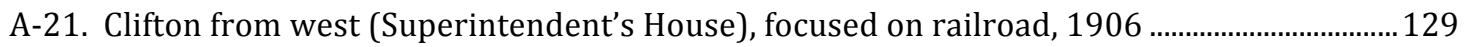

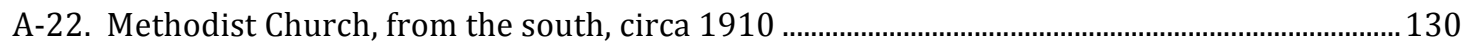

A-23. Log Cabin Row with Methodist Church in background, from south, 1901...............................130

A-24. Avery Shaft surface plant during Calumet \& Hecla period, from south, circa 1930's............131

A-25. Avery Shaft surface plant during Calumet \& Hecla period, from north, showing Clifton, circa 1930 's..

A-26. Rock piles located at the Howe Shaft with shaft house remains visible, from the east, circa

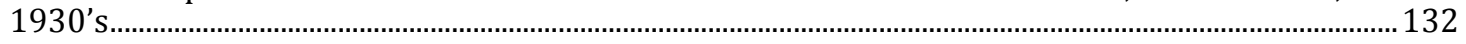

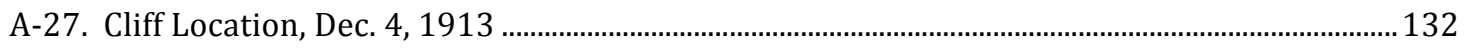

A-28. Detail of a blueprint map of the Cliff Mine and Clifton, circa 1870's-1880's ...........................133

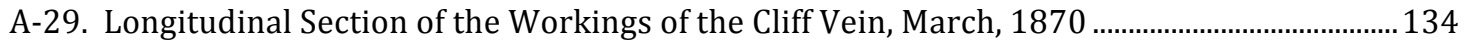




\section{List of Tables}

1. Dividends Paid by the Pittsburgh and Boston Mining Company, 1849-1879 .............................. 54

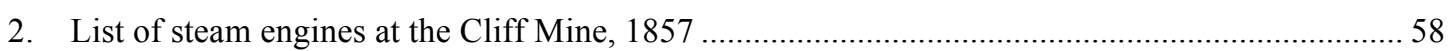

3. Copper Mines and Mining from DeBow's Review, 1853 ………………………………........... 59

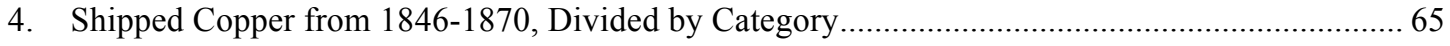

5. Figures Relating to Stamping and Washing at the Cliff Mine, 1857-1870 ..................................... 76 


\section{Introduction}

\section{The Cliff}

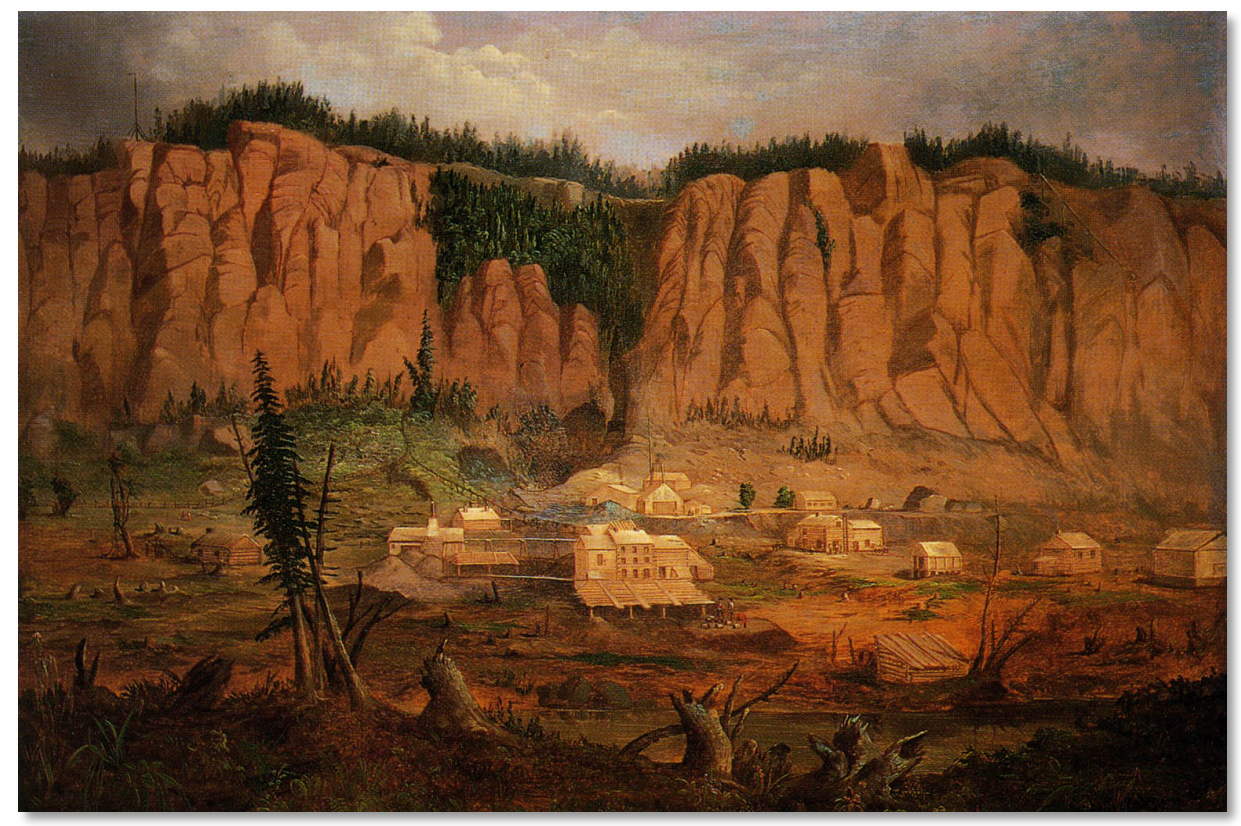

Fig. I-1. Robert S. Duncanson's "Cliff Mine, Lake Superior." 1848. (F. Ward Paine, owner)

"From the lake, going nearly south to the Cliff, we ascend gradually till we reach the top of the hill, five or six hundred feet above the level of the Lake, two and a half miles inland. A road has been constructed at much expense-still very rough and uncomfortable. The wet places are bridged with round logs, technically termed corduroy. The land is heavily timbered with birch, maple, hemlock, etc., and well watered with numerous springs. Passing through a defile, we gradually descend, by means of a road which winds around the side of the bluff, to the south. As you descend, to your left is a deep chasm, which forms the valley of Eagle River. Here you [go] down on the tops of tall trees and far beyond that land rises to view in mountainous ranges. Here a cold spring gurgles from the Cliff...a delightful little stream tumbles down the precipice, and makes music on the ear. To your right the Cliff now rises above you in majesty and grandeur. ... The top of the Cliff is two hundred and twenty feet above the west branch of Eagle River. Here one would suppose that nature in one of her freaks, had attempted to shake down the mountain; for in every direction lay broken masses and heaps on heaps of the trap rock thrown down from the top. As you look... at the summit, you would naturally imagine that some were just ready to leap from their fastnesses. And should they do so, woe betide whatever was beneath them.",

\footnotetext{
${ }^{1}$ Rev. John H. Pitezel, Lights and Shades of Missionary Life: Containing Travels, Sketches, Incidents, and Missionary Efforts During Nine Years Spent in the Region of Lake Superior (Cincinnati: Western Book Concern, 1857), pps. 166-67.
} 
This is a description given by the Reverend John H. Pitezel as he approached "The Cliff" in the summer of 1848. The Cliff Mine was still in its infancy, having only been opened two years before. The description Pitezel gives speaks to the unknown nature of the western United States in the early to mid-nineteenth centuries. The Upper Peninsula of Michigan at this time was a vast wilderness, where wealth could be picked up off the ground if one only felt adventurous enough to go and find it.

This mentality can also be seen in 1848's "Cliff Mine, Lake Superior," painted by Robert S. Duncanson (Fig. I-1). The awesome cliff face towers over the mine workings, dominating the scene. The miners depicted are indistinguishable from the surrounding trees and stumps. It is impossible to separate the mine from the precipice it lies beneath. The message is clear; these men are living and working in an unknown and dangerous land.

And indeed they were. At the time of Pitezel's and Duncanson's visits, the presence of native copper was well known, but a clear understanding of its tendencies was not. This new country would challenge long held beliefs and practices about copper mining. The earliest mining enterprises arriving in the Keweenaw came with Old World knowledge brought from the metallic mines of Cornwall and Germany. In Europe, the mineral's location and tendencies were understood in those contexts. Distances from the mine to market were short, and mining could be done profitably with little worry. In the Upper Peninsula, things couldn't be more different. Native copper was unpredictable. No one yet understood where, at what depth, and in what quantities it could be found. More than that, the remoteness of the Upper Peninsula meant that the processing and marketing of finished product would need to occur hundreds of miles, and many days journey, away. Old World knowledge was not terribly useful. Consistent capital, patience, and adaptability would also be required if copper mining in the Upper Peninsula was to ever be profitable. A little luck wouldn't hurt either.

A lack of one or more of these necessities doomed many of the early mining attempts in the area as the shafts, coffers, or personal fortitude pinched out too quickly for most. For one failure however, the luck ran deep enough to make a go of it long after others would have cashed in. The Pittsburgh and Boston Mining Company's Lease 4 


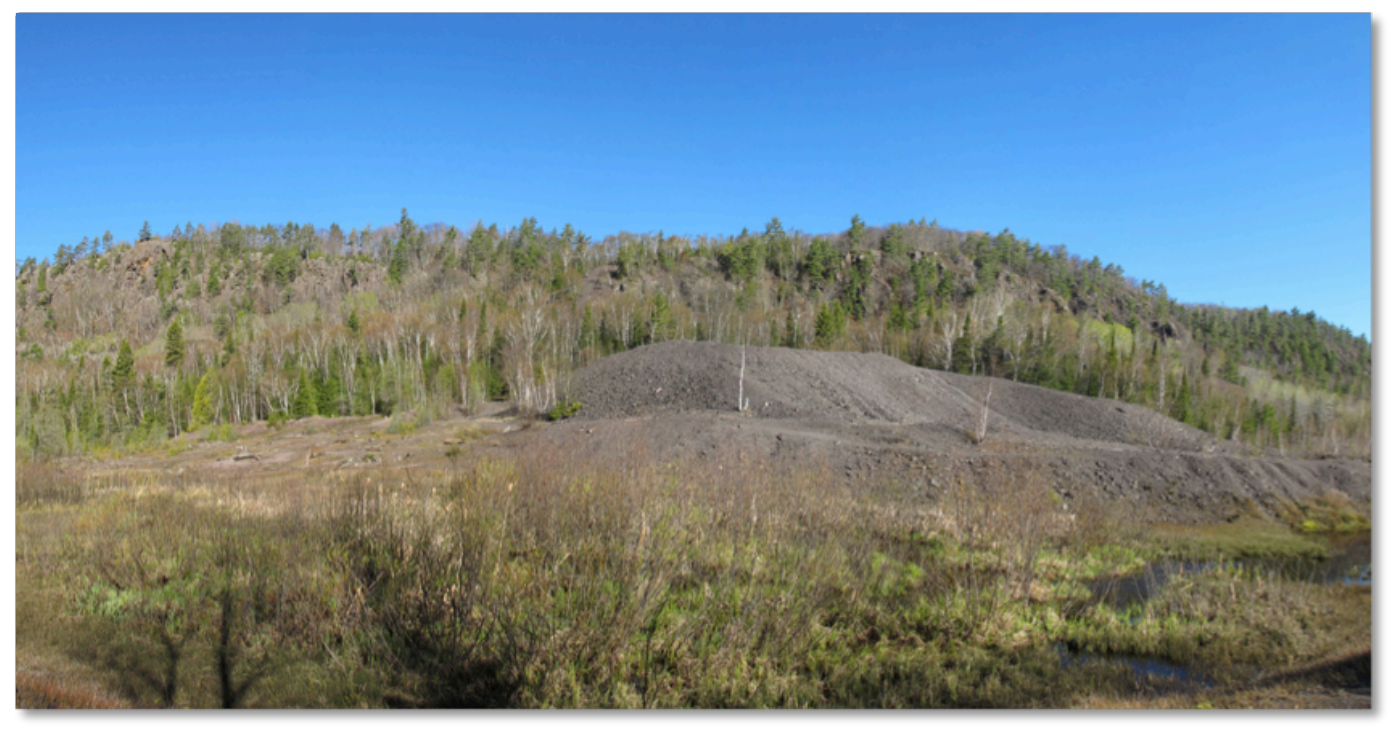

Fig. I-2. The Cliff Mine as it looks today. Waste rock piles and stamp sand obscure the once thriving operation. (Image by author)

property at Copper Harbor consumed nearly $\$ 25,000$ in operational costs while yielding roughly $\$ 3,000$ in marketable copper from $1844-45$. $^{2}$ A return on investment like this would have crippled most, but not the P\&BMC. The company held two other leases, 5 and 6 , the latter of which would be home to the six mile long cliff range, the sharp, abrupt 200 foot drop where the Cliff Mine would be established. By accepting failure at Lease 4 and investing more capital at Lease 5, the P\&BMC would be rewarded with a discovery at the base of that cliff that astounded the world and challenged what the Old World knew to be true.

The discovery made at the base of Pitezel's majestic and grandiose cliff meant that it was possible to mine native copper profitably in the Lake Superior region. It also directed the Pittsburgh and Boston Mining Company to follow a path to quick profits and future headaches. As is often the case when you are the first, your model doesn't fit because it hasn't been made yet.

Look again at Duncanson's painting. In it we can see the artist's unknowingly foreshadow the problems the Cliff Mine would face in the future. The mineral wealth the

\footnotetext{
${ }^{2}$ Donald Chaput, The Cliff: America's First Great Copper Mine (Kalamazoo: Sequoia Press, 1971), p.22.
} 
company sunk shafts and expended enormous energy to procure lay not at the base of the cliff but instead far underneath the top of it. The "Cliff" in the painting is now more than just representative of a foreign, unknown land. It literally holds the mine captive, shaping the decisions of the company for years to come. It is the inescapable symbol of the mine's success and eventual demise.

When you drive by the Cliff Mine site today (Fig. I-2), all that is easily discernable of the mine are the waste rock piles that obscure the workings portrayed in the painting. Even the cliff itself has been altered by this rock, a large apron of which now drapes the bluff as though Pitezel's assertion was correct; that nature did indeed try to shake down the mountain that which it once held tightly. Yet behind those rock piles lie the physical evidence of the Cliff Mine's rise and fall. Mine shafts, stone foundations, smoke stacks, tramway paths, and wagon roads are still visible beneath 150 years of time. The remains of these structures and the networks associated with them tell the story of how the mine began, how it flourished, and how it tried to adapt as their luck slowly ran out.

\section{Site Overview}

The site of the Cliff Mine is located in Allouez Township, Keweenaw County, Michigan. Keweenaw County is the northernmost county in the Upper Peninsula of Michigan, and occupies the northern half of the Keweenaw Peninsula, a finger of land jutting north and east into Lake Superior. The County has a yearlong population of around 2,500, and is a destination for thousands of seasonal vacationers attracted to heavy winter snows and mild summers. The Cliff Mine's location in a seemingly natural and sparsely populated area fits comfortably within this tourist/vacation economy.

Much of the site, and the areas comprising the focus of this research, is owned by the Keweenaw County Road Commission, who purchased it from the Calumet \& Hecla Mining Company, interested in the waste rock piles that could be used for road construction. Located on a seasonal road (Cliff Drive), the site is closed to all but snowshoe, ski, and snowmobile traffic for half of the year. The summer months see frequent visits by hikers, rock pickers, amateur historians, off-road vehicle enthusiasts, 
and the occasional bear. Cliff Drive divides the site into two parts: the mine itself to the north, the former town site of Clifton to the south.

At its height, Clifton was home to nearly 1,500 residents. Located on a triangular parcel of land bracketed by two modern roads, it is now covered mostly in swamp, apple trees, and pine. The remains of three churches, numerous homes, a cemetery, and a large farm are still evident on ground, stone and earthen foundations providing an ephemeral map of the town. Mining also occurred here, and is evidenced by rail spur remains and a long capped mineshaft.

Across Cliff Drive, the mine proper hides behind large waste rock piles built up over decades. The west branch of the Eagle River trickles through marshes clogged with stamp sand deposited at the same time as the rock piles. Beaver dams have relegated the river to almost seasonal status. Beyond the rock piles, cedar, tamarack, maple, and oak dot the lower reaches of the cliff, giving way to craggy trap rock overhangs half way up. Stone foundations, tramways, large steam stacks, and another cemetery are also visible amid the trees. Red flagging tape left by the local historical society marks the "safe" path for hikers and curiosity seekers wondering where all this rock could have come from.

At the top of the cliff there are still more remains. Foundations and rock piles are reachable via logging road and hiking trail. Sitting at the crest of the greenstone bluff, one can see roughly 20 miles in all directions, making Lake Superior visible to the north and south. The site is thus widely spread out, covering nearly 300 acres and over 250 feet in elevation.

\section{Previous Research}

Donald Chaput undertook the first serious look at the Cliff Mine in his 1971 book, The Cliff: America's First Great Copper Mine. Focusing on historical narrative, Chaput pieced together newspaper accounts and annual stockholder reports to tell the story of the mine's success. Though a scholarly work, The Cliff was not concerned with the technical aspects in relation to the physical remains at the site but instead focused on popular history. However it is the definitive account of the Cliff Mine as a company and any 
future research can only build on its foundation. The source material gathered for the book is a good collection of direct, primary source material regarding Cliff. ${ }^{3}$

Other locally published books have also been written about the mine. Clarence Monette's, Clifton and the Cliff Mine, and Don H. Clarke's, Copper Mines of the Keweenaw, The Cliff Mine, both written for the amateur historian, provide historical narrative and technical fact and figures outside an academic context. The popularity of Monette's work is one of the prime movers of interest in the mine locally; visitors can often be seen with a copy in hand as they walk the site. Monette's collection of resources, donated to the Michigan Technological University Archives, is also a treasure trove of information and correspondence between him and the institutions that held many of the primary sources dealing with the Cliff Mine. ${ }^{4}$

A third book, Copper Country Journal: The Diary of Schoolmaster Henry Hobart, 1863-1864, takes a look at the mine from a non-mining perspective. Edited by Philip Mason, Professor of History at Wayne State, University, Hobart's year and a half long account details the daily lives of the people who worked and lived in and around the mine, what they ate, how they passed the time, how they were educated, and what constituted their day-to-day thoughts and feelings are described. As a teacher, Hobart had little knowledge of mining but he still provides a detailed description of the work going on under and above ground. Of particular interest in this book is the constant presence of death and sickness. There are pages of entries devoted to mine accidents and children who've succumbed to sickness and disease. ${ }^{5}$

Archaeological research has also taken place at the Cliff. In the summer of 1973, investigations under the direction of Dr. Eleanor De Ling Andrews, an assistant professor at Michigan Technological University, were undertaken as part of a field school course in archaeological methods. Due to illness and a variety of other factors, a written report of the fieldwork's findings was not completed until 2004. The thirty-year gap between

\footnotetext{
${ }^{3}$ Donald Chaput, The Cliff: America's First Great Copper Mine (Kalamazoo: Sequoia Press, 1971).

${ }^{4}$ Clarence Monette, Clifton and the Cliff Mine (Calumet: Greenlee Printing Co., 1999). and, Don H. Clarke, Copper Mines of the Keweenaw, The Cliff Mine (1976).

${ }^{5}$ Philip P. Mason, ed., Copper Country Journal: The Diary of Schoolmaster Henry Hobar, 1863-1864. (Detroit: Wayne State Press, 1991).
} 
fieldwork and report meant that loss of data, artifacts, and memory diminished the report's effectiveness in giving a clear picture of the Cliff site.

The field investigations focused primarily on a portion of the site to the northeast of the mine proper. This area consisted of a powder house (for storage of explosives), a community building, a possible blacksmith shop, and the Protestant cemetery. Documentation and artifact collection was methodologically flawed, and the loss of accurate contextualized mapping in the report renders many of the findings speculative at best. In terms of the present project, De Ling's area of focus lies primarily outside the technical networks of interest. The locations of archaeological excavation appear to be made out of convenience rather than for their research potential. The value of this report lies not in what it set out to do, but rather as an example of how responsible academic investigations require timely reporting of findings. ${ }^{6}$

\section{Research Design}

This thesis will combine archival research with six weeks of fieldwork in conjunction with a field school in Industrial Archaeology put on by the Social Sciences department at Michigan Technological University in the spring of 2010. Previous research in the Cliff Mine has focused primarily on the company history or the daily lives of the residents of Clifton. Past research has largely avoided the physical remains of the mine and town, mainly due to its relative inaccessibility and private ownership. Therefore the primary goal of this field school was to document structures, both extant and ephemeral; in order to recreate the technical networks operating at the mine.

\section{Archival/historical research}

The Michigan Technological University Archives and Copper Country Historical Collections provided the bulk of documentary source material. Primary sources such as the Pittsburgh and Boston Mining Company's annual stockholder reports listed earnings, expenditures, and detailed descriptions of the status of the mine's operations. These descriptions include structural improvements, changes in machinery/technology, and the

\footnotetext{
${ }^{6}$ Eleanor De Ling Andrews, "The Cliff Mine Site A Historical and Archeological Study: Fieldwork through Michigan Technological University in 1973," 2005. Page numbers ommitted as the digital format in which this report was acquired lacked them.
} 
distances drifted/excavated underground. Altogether, the annual reports for every year (save four) from 1848 to 1870 are present at the archives in original or photocopy form.

Local newspapers on microfilm are littered with personal accounts and editorials of the mine as well. Since the annual reports are written for stockholders, many of whom have little technical knowledge of mining, these newspaper accounts written for an audience living in a mining region are often written with greater concern given to technical detail. References to the machinery and those contracted to build and install it were for the most part found only in these local newspapers. Advertising testimonials were especially useful in uncovering the technical processes of mineral extraction. They also contain personal accounts of visitors to the mine that shed light on the location of structures in relation to one another. Mines are constantly under change as capital enterprises spend more to keep up with the shafts' ever increasing depths. Often new structures are built on top of one another, and early visitor accounts are all that is left to piece together the earliest footprint of a mining operation.

In this thesis, I use these sources to establish a chronology of the Cliff's technological systems. From horse-whims to the adoption of steam power, to the implementation of the Man-engine, the mine underwent specific periods of technological advancement. Defining these periods with the aid of historical documents will provide a structure to the ensuing fieldwork, assisting in identifying structures and their associated technical networks.

\section{Documentation}

Field school participants documented structures in order to recreate the technical networks operating at the mine. The aim was to create a map and GIS, using traditional field documentation methods as well as more recent technologies. Specifically, this was done with measured drawings, photography, and surveying, combined with Global Positioning Systems (GPS), aerial photography, and Light Detection and Ranging (LiDAR).

Starting with the industrial core of the site (termed Avery Shaft Complex and Stamp Mill), documentation branched outwards, mimicking the movement of the mined copper from shaft to mineral yard. As the mine sunk further under the bluff, surface 
operations had to be moved in order to adapt to this change. Fieldwork will therefore also move, noting these changes as the No. 4 Shaft (located at the top of the bluff) replaced the Avery Shaft as the primary extraction point. Finally, support buildings, roads, and tram ways will need to be linked from the shaft complexes to the mill, the final stop for much of the copper before leaving for the furnace.

\section{Community Outreach}

Along with the documentation of the site, the field school engaged in community outreach. This took the form of public "open houses" and tours of the site, guest lectures from both Michigan Tech and local historians, and the inclusion of volunteers from the local community. Additionally, a weblog devoted to the project was created and maintained by the author to aid in disseminating information regarding research into the Cliff Mine site. ${ }^{7}$ It is the aim of this research to provide an informed document regarding the site that is both academic and accessible to the public. It is felt that the Cliff Mine is a site of community pride with a potential for that pride to grow exponentially. What is needed to achieve this is a better understanding and interpretation of the site itself.

\section{Thesis Organization}

The intention of this thesis is to utilize the physical and ephemeral remains of the site in combination with historical documents and images to better understand the operations of the Cliff Mine as it faced the challenges of mining native copper. Chapter 1 provides an historical context for native copper mining in the Lake Superior region. It will cover geology, prehistoric mining, early accounts of native copper by European explorers and missionaries, as well as America's interest in the region leading up to the discovery of the Cliff Mine. Chapter 2 details the history of the Cliff Mine, focusing on the Pittsburgh and Boston Mining Company's period of direct management (1846-1870). The mine's history extends well into the mid-twentieth century, but for the purposes of this thesis, the P\&BMC's period of management is of primary concern. Chapter 3 contains all documentation data gathered during the 2010 field season as it pertains to the thesis' objectives, along with identification of features and their possible purposes.

\footnotetext{
${ }^{7}$ http://cliffmine.wordpress.com. Created 10 April, 2010 by Sean M. Gohman.
} 
Measured drawings, photographs, and maps associated with this chapter can be found in Appendices A \& B. Chapter 4 synthesizes the material in Chapters 2 and 3 to address the research goals while Chapter 5 provides recommendations for further research and interpretation of the site. 


\section{Chapter 1:}

\section{Historical Context for Native Copper Mining in Lake Superior}

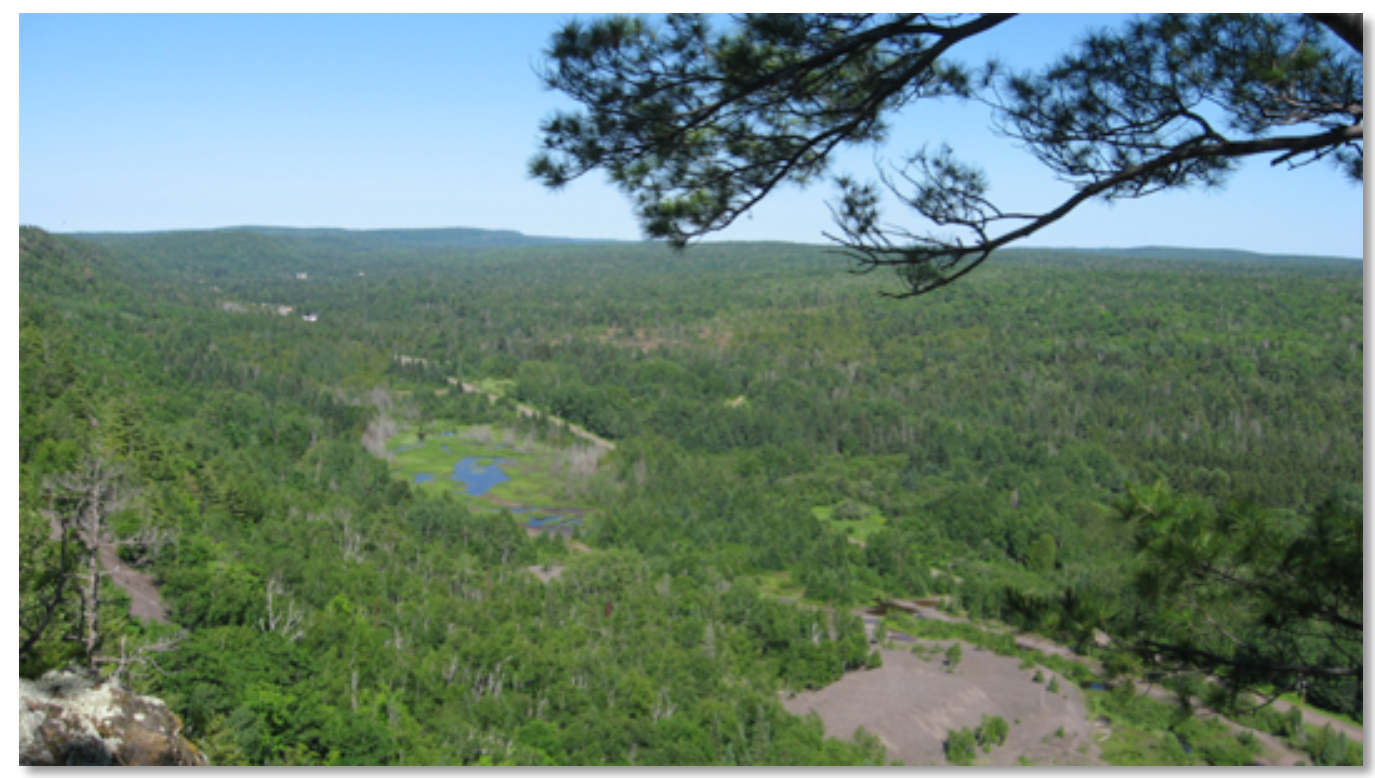

Fig. 1-1. View of the Cliff Mine and townsite of Clifton, summer of 2009. All that are easily discernable are the rock piles at bottom right. (Image by author)

"When it is considered that nearly the entire copper region is an unreclaimed wilderness, the miners' settlements appearing like mere dots on its surface, covered with a dense growth of trees, through which the explorer with difficulty forces a path; and that, except where the streams have worn their beds in the rock, or the hills terminate in bold and craggy ledges, the ground is covered with a thick carpet of mosses and lichens, effectually concealing every trace of veins, it is surprising that such an amount of mineral wealth has been revealed within so short a period."7

\section{Geology of the Keweenaw}

Some of the oldest rocks in the world can be found in the Keweenaw Peninsula, its formation having begun over one billion years ago. During the Earth's violent past, periodic eruptions of lava, now termed Portage Lake Lava Series, flowed over what later became the Lake Superior basin. This molten rock, once solidified, layered deposits of basalt or trap rock, which now form the western half of the Keweenaw. One of these

\footnotetext{
${ }^{7}$ J.W. and Whitney, J.D. Foster, Report on the Geology and Topography of a Portion of the Lake Superior Land District. (Washington: House of Representatives, Executive Doc. 69. 31 st Congress. 1st Session., 1850), p.152.
} 
layers, the Greenstone flow (a thousand feet thick in places), may in fact be the largest single lava flow the world has ever seen. ${ }^{6}$ Together, these lava flows comprise the trap range, which extends from the tip of the peninsula and, "runs west for twenty miles; then, curving to the southwest, crosses Portage lake near its head, and the Ontonagon river twelve miles from its mouth, and is thence prolonged into Wisconsin. Its length is more than one hundred and fifty miles; its width, from one to twelve." long strip of rock became home to the vast majority of native copper found in the Keweenaw.

After some of these volcanic events (there may have been as many as 200), the cooling basalt became pocked with minute gaps and spaces as gasses released into the air. Often a layer of gravel and boulders, washed down from streams and rivers, then covered the surface, creating a barrier of conglomerate rock between each layer of trap. Over time, this created a layer cake of trap, conglomerate, and amygdaloid belts ${ }^{9}$. The pressure of the Earth's ever shifting mantle (the Keweenaw fault runs the length of the peninsula) then squeezed these layers upward; creating the Lake Superior basin. At each end of this basin, the Keweenaw Peninsula (in the southeast) and Isle Royale (in the northwest) rose upwards, mirroring each other geologically. Under immense constriction and pressure, this layer cake fractured, and the resulting fissures over time filled with metallic copper deposited by rising water from below. ${ }^{10}$

In nature, copper is often found chemically bound to other elements, often sulfur or oxygen. Native copper is free of this chemical binding, and is usually found at or near the surface of combined copper sulfide and oxide lodes. For copper bearing regions such as Cornwall, copper exists in a sulfide form combined with iron, and needs to be

\footnotetext{
${ }^{6}$ David J. Krause, The Making of a Mining District: Keweenaw Native Copper 1500-1870 (Detroit : Wayne State University Press, 1992), p.44.

${ }^{8}$ J.W. and Whitney, J.D. Foster, Report on the Geology and Topography of a Portion of the Lake Superior Land District. (Washington: House of Representatives, Executive Doc. 69. 31st Congress. 1st Session., 1850), p.34.

${ }^{9}$ William Pettit, "Remarks Respecting the Copper District of Lake Superior, Made at the Monthly Meeting of the Franklin Institute, March 18th, 1847.," Journal of the Franklin Institute XLIII (1847): 340-41. The term amygdaloid (shaped like an almond) refers to the gaps left behind within the rock as gas and water are released.

${ }^{10}$ David J. Krause, The Making of a Mining District: Keweenaw Native Copper 1500-1870 (Detroit : Wayne State University Press, 1992), pp.45-47.
} 
carefully smelted in order to separate the metallic copper from the noxious sulfur. Native copper, being essentially pure metal, requires little sophistication in smelting. ${ }^{11}$

The precise reasons why native copper is so prevalent in the Lake Superior region is only partly understood, but the overall idea is rather simple. Great temperatures and pressures under the various layers of trap and conglomerate rock probably forced water up through the amygdaloid and conglomerate layers, leaving elemental copper to fill in the gaps. As the water rose to the surface, where temperatures and pressures are less extreme, the solution left behind larger masses of copper in the fissures. Since the trap rock layers of the area are free of sulfur, this remaining copper would primarily exist in its pure, or native, state.

Over time, other layers of rock have also contributed to the formation of the Keweenaw. Covering the low-lying eastern portion of the peninsula is the reddish Jacobsville sandstone. To the west, Copper Harbor conglomerate competes with sand dunes to give a craggy, ancient appearance to the shoreline. Native copper's presence however is confined to the Keweenaw's middle, the Portage Lake Volcanic series, in three types of lodes: conglomerate, amygdaloid, and fissure. The conglomerate and amygdaloid lodes are similar in that they run parallel to, and at the same dip/angle as the rest of the trap layers on the peninsula. The copper found within these pocketed layers is in small particles, disseminated throughout long lodes of mineral bearing rock. The fissure lodes are different. Generally running perpendicular to the trap and vertically downward, the fissures can at times be filled with veins of copper many feet thick. ${ }^{12}$

During the Ice Age, glaciers covered and retreated many times over the Lake Superior region, reshaping the land to its present configuration. Moving glaciers carved softer, more recent rock away, exposing the underlying erosion-resistant trap and copper bearing belts to the surface. The retreating glaciers often ripped newly exposed outcrops of copper from the fissure lodes, carrying them elsewhere. Decades of floating within the ice smoothed these large masses, until finally being deposited sometimes far from their original source. Native peoples, moving into the Great Lakes region after the glaciers

\footnotetext{
${ }^{11}$ Ibid, pp.49-50.

${ }^{12}$ Ibid, pp.45-48.
} 
retreated, found these pieces of float copper, and utilized them for practical and spiritual purposes. $^{13}$

\section{Prehistoric Copper Mining}

The mild summer climate, excellent fishing, and easily accessible outcrops of copper brought peoples to the Keweenaw Peninsula for millennia; the native populations were able to utilize and trade copper throughout North America. ${ }^{14}$ Native mining technique consisted of heating the berock located in these outcrops. Once heated, cold water would be poured over them, quenching and disintegrating the rocks through contraction. With the use of a stone hammer, copper could be freed from the surrounding rock, the smaller pieces being suitable for trade or continued working into tools and ornaments.

Native people would also dig down along these outcrops, creating shafts as deep as 50 feet (and possibly more) with timbered scaffolding in some cases. The large numbers of open pits and ancient mining remains made it easy for future mining agents to identify productive sources of copper. Nearly all of the $19^{\text {th }}$ century mines started in the Keweenaw began near ancient mining remains, the locations often found to be littered with "Indian hammers...chisels...[and] ancient diggings" (Fig. 1-2). ${ }^{15}$ Aboriginal mining was prevalent but harsh Lake Superior winters probably prevented permanent settlement on the peninsula. Charles Whittlesey remarked in 1852 for The Annals of Science that although there are many ancient mining remains in the vicinity of Portage Lake, "There is nothing to show that the country was permanently inhabited...as their works were open cuts and not galleries...[making them] impracticable to work them in the winters of that latitude." 16

\footnotetext{
${ }^{13}$ Susan R. Martin, Wonderful Power: The Story of Ancient Copper Working in the Lake Superior Basin (Detroit: Wayne State University Press, 1999), pp.28-29, 33-35.

${ }^{14}$ Ibid, pp.131-136.

${ }^{15}$ John R. Halsey, "Ancient Diggings: A Review of Nineteenth-Century Observations in the Prehistoric Coper Mining Pits of the Lake Superior Basin," 45th Annual Meeting of the Midwest Archaeological Conference (Milwaukee: Courtesy of S. Martin, 2008), pp.35-39.

${ }^{16}$ Roy W. Drier, "Pre-Historic Mining in the Copper Country," Prehistoric Copper Miing in the Lake Superior Region: A Collection of Reference Articles, ed. R.W. Drier and O.J. Du Temple (Calumet: Roy W. Drier, 2005), p.27; Charles Whittlesey’s 1854 work, Ancient Mining on the Shores of Lake Superior
} 


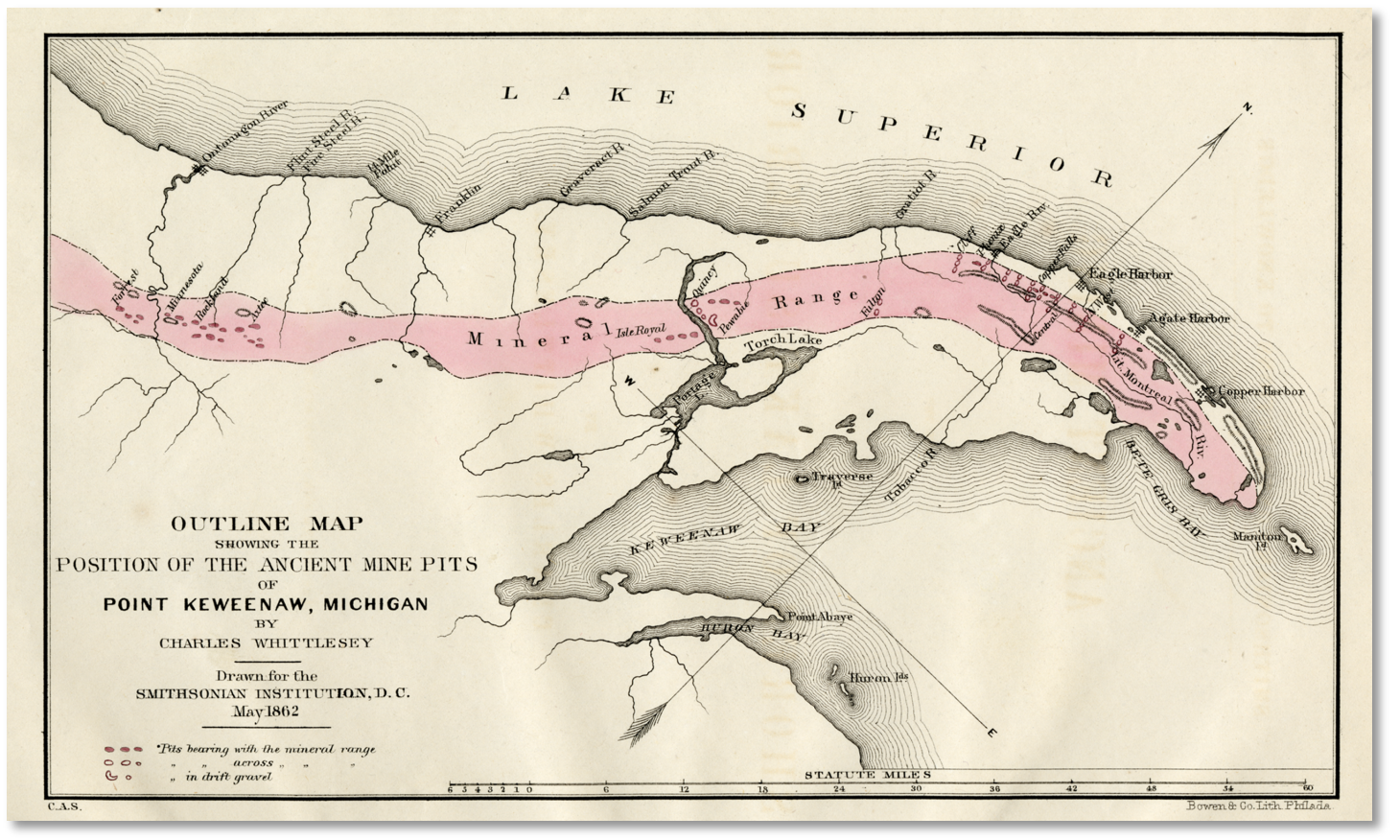

Fig. 1-2. Charles Whittlesey's, "Outline Map Showing the Position of the Ancient Mine Pits of Point Keweenaw, Michigan. (F572C8W45-01-01, Book Collection. Michigan Tech Archives and Conner Country Historical Collections)

Copper was a natural and cultural resource linking the Great Lakes region to the Atlantic Coast. Trade in copper, whether worked or not, occurred continuously from as long ago as $8000 \mathrm{BP}$ through points of European contact. From the Paleo-Indian period to the Late Woodland, native peoples found a practical, and in many cases spiritual, use for copper. Spiritual entities called manitous were thought to own the copper, imbuing it with supernatural power. To possess ornaments or weapons of this metal therefore meant one could harness and utilize the power of the gods themselves. ${ }^{17}$ By the time the French first entered the St. Lawrence Seaway however, knowledge of copper's origin in the area became clouded, as drastic changes brought on by European contact affected the populations of the Great Lakes. Disease, population migration, and an unwillingness to share the manitous' power meant that for Europeans, obtaining copper would require a tremendous amount of time and effort.

(Washington: Smithsonian Institute, 1863) was one of the first extensive, albeit contradictory at times, accounts of prehistoric copper workings.

${ }^{17}$ Susan R. Martin, Wonderful Power: The Story of Ancient Copper Working in the Lake Superior Basin (Detroit: Wayne State University Press, 1999), pp.199-204. 


\section{Early European Accounts}

Though not the first Europeans to explore the North Atlantic coast of the Americas, the French were the first to encounter stories of copper existing in the Great Lakes region. Jacques Cartier makes the earliest mention of Great Lakes copper in the fall of 1535, and brought back to France a knife made from the red cagnetdaze of the "Province of Sagueney."18 70 years later, in 1604, Samuel de Champlain describes finding copper mines in what are now the Maritime Provinces of Canada. He claims to have been presented a piece of copper a foot in length, and that the native peoples, "gathered it in lumps...melted it, spread it in sheets, smoothing it with stones."19

The next century would see the rise of what became known as the French Regime in Canada. Focused on developing trade networks with the native population, the Regime sent out explorers and Jesuit missionaries across the Great Lakes region in order to attain wealth for the Crown and souls for God. Etienne Brule was one of the first such explorers tasked to live among the natives, that he may, "ascertain the nature of their country, see the great lake, observe the rivers and tribes there, and also explore the mines and objects of special interest in the localities occupied by these tribes. ${ }^{, 20}$ Brule spent the better part of the next 15 years among the Huron, Algonquin, and Ojibwe, and may have been the first European to see Lake Superior. Brule claimed to have visited a copper mine on his travels and even presented Champlain an ingot of copper he said came from the north shore of Lake Huron after one of his returns to Quebec in 1626.

French Jesuits also told, often in fanciful terms, of copper's existence in relations detailing their missions to the Great Lakes. Fathers Radisson and Groselliers, two of the

\footnotetext{
${ }^{18}$ James Phinney Baxter, A Memoir of Jacques Cartier: Sieur de Limoilou, His Voyages to the St. Lawrence, a Bibliography and a Facsimile of the Manuscript of 1534, with Annotations, etc. (New York: Dodd, Mead \& Company, 1906), pp.135-206. Cagnetdaze being the french translation for the Iriquois word for copper.

${ }^{19}$ Consul Willshire Butterfield, History of Brule's Discoveries and Explorations 1610-1626: Being a Narrative of the Discovery, by Stephen Brule, of Lakes Huron, Ontario and Superior; and of His Explorations (the First Made by Civilized Man) of Pennsylvania and Western New York, also of the Province of Ontario, Canada: with a Biographical Notice of the Discoverer and Explorer, who was Killed and Eaten by Savages. (Cleveland: The Hellman-Taylor Company, 1898), pp. 101-103. And, Samuel de Champlain, Voyages of Samuel de Champlain: 1604-1618, ed. W.L. Grant (New York: Charles Scribner's Sons, 1907), pp.36-37.

${ }^{20}$ Samuel de Champlain, Voyages of Samuel de Champlain: 1604-1618, ed. W.L. Grant (New York: Charles Scribner's Sons, 1907), p.185. And Butterfield (1898), pp.100-105.
} 


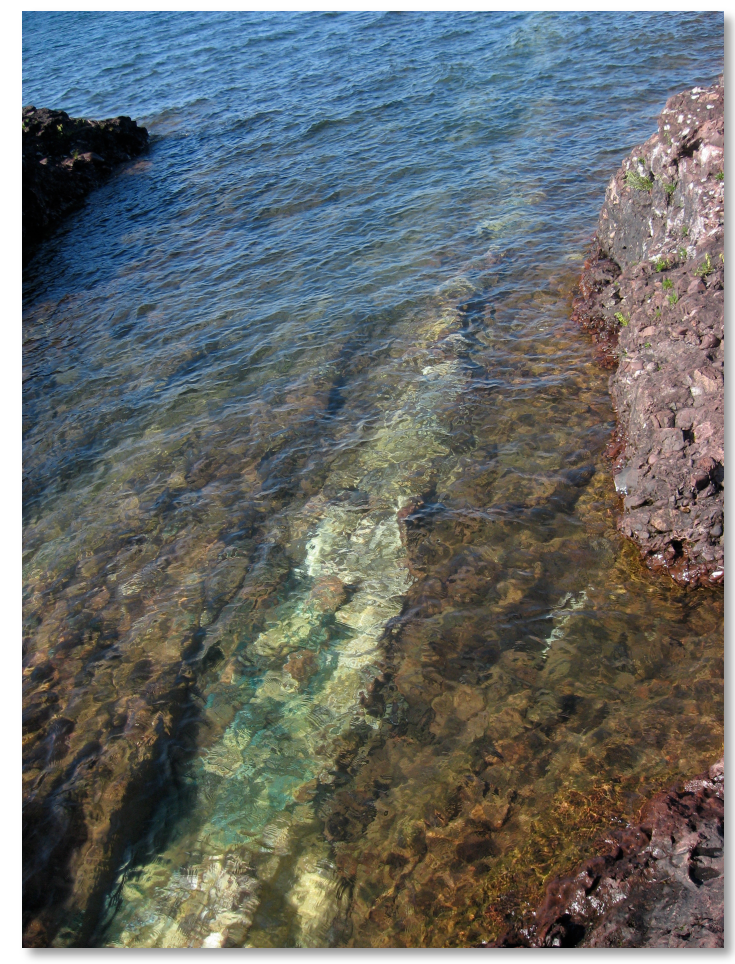

Fig. 1-3. La Roche Verte (the Green Rock) on Hay's Point, Copper Harbor, MI. The green and white vein of copper silicate seen by fur trading voyageurs was one of the most visible clues to the mineral wealth of the Keweenaw Peninsula. (Image by author)

earliest missionaries to reach Lake Superior, told of being shown entire mountains and islands in the lake, "all of copper." Fantastic claims aside, more realistic accounts to the existence of native copper also made it back to Quebec and France. Father Lalemant spoke of pieces of copper as large as one's fist, and Claude Dablon, in his relation of 1671-72, told of visiting a great copper boulder "seven or eight hundred livres in weight" on Isle Royale. ${ }^{21}$ On Keweenaw Point, the northernmost finger of land on the southern shore of the lake, French voyageurs made note of a curious green streak of copper silicate, La Roche Verte, running along the bottom of the lake from the shore and still visible a great distance under water (Fig. 1-3). Through these Jesuit relations, The French slowly became more and more aware of the likely presence of profitable quantities of copper in the region. Finding where to mine it, and tackling the issue of getting it out of the Great Lakes, was another story.

\footnotetext{
${ }^{21}$ Pierre Esprit Radisson, Voyages of Peter Esprit Radisson: Being an Account of His Travels and Experiences Among the North American Indians, from 1652-1684., ed. G.D. Scull (Boston: Prince Society, 1885), pp.191-192; Rueben Gold Thwaites, The Jesuit Relations and Allied Documents: Travels and Explorations of the Jesuit Missionaries in North America (1610-1791), With an Introduction by Reuben Gold Thwaites, ed. E. Kenton (New York: Albert \& Charles Boni, 1925), pp.305-327. A livre being a french term of currency, not weight.
} 
Jean Talon, appointed Intendent of New France in 1665, would be the first to take on the challenge presented by Great Lakes copper. A man of foresight, Talon felt the colony of New France required industry and the raw materials to feed that industry in order to survive. Successful mining could lead to the establishment of smelters and mills in New France, supplying copper for the production of muzzles the French army needed for their cannon. Talon sent out three unsuccessful expeditions in the late 1660's to narrow down specific sources of copper. ${ }^{22}$ Unfortunately for Talon, copper's position in the cosmology of the native population of the Great Lakes meant that divulging the source of copper brought no benefit. Father Allouez, a missionary in the region at this time, stated that he believed the natives hid the truth about the sources of copper, and required "cuteness to draw such information from them." The natives told missionaries and explorers stories of powerful manitous who guarded the copper. One of these was Missibizi, who lived on the "floating" island of Michipicoten in the north of Lake Superior, who cursed any who attempted to take, "the cradles and toys of [Missibizi's] children." Through the clouds of myth and half-truths, Allouez eventually came to some certainty about the locations of the mines. He narrowed the focus to the south shore of Lake Superior, and even mentioned the arrow shaped Keweenaw Peninsula as a probable location. ${ }^{23}$ Allouez's correct assertions came too late however; Talon's tenure as Intendent ended nearly as soon as it began, and it would be another 60 years before any serious attention could be given to the region's copper again.

\section{Early Mining Attempts}

That attention would come from another Frenchman, Louis Denis, Sieur de la Ronde. Commissioned with the command of the trading post at Chequamegon Bay (near La Pointe, on Madeline Island, WI) in 1727, de la Ronde was a man with grand plans. Within a year of his arrival to Lake Superior he had already sent samples of copper ore to France to be assayed. While awaiting the results he felt certain would be positive, de la

\footnotetext{
${ }^{22}$ Louise Phelps Kellogg, The French Regime in Wisconsin and the Northwest (Madison: State Historical Society of Wisconsin, 1925), pp.131, 348-349; Thomas Bertram Costain, The White and the Gold: The French Regime in Canada (Garden City: Doubleday \& Company, Inc., 1954), pp.269-277.

${ }^{23}$ Rev. C.P. Verwyst, Missionary Labors of Fathers Marquette, Menard and Allouez, in the Lake Superior Region (Chicago: Hoffmann Brothers, 1886), pp.89-94.
} 
Ronde appealed to the French Crown for funding in order to build ships for the transportation of future ore. He waited five years for a response.

After finally receiving permission to prospect and mine copper ores, de la Ronde built a 25-ton vessel at Sault Ste. Marie for the purpose of transporting men and material back and forth between there and La Pointe. De la Ronde's mineral explorations focused along a stretch of shore from the Iron to Ontonagon Rivers, and opened four promising veins in the next few years. Upon seeing one of these French mines, a visiting expert from Europe remarked, "One could never see a mine, apparently finer, and it is certain that if one wished to start in the business and invest money there, a great return of copper might be hoped for." De la Ronde, convinced glowing accounts like this would guarantee more backing, proceeded to create a small community to support his mining venture. La Pointe became a small agricultural community, with a fort, dock, and mill. At the mines on the Iron River, a fort and furnace were built, and de la Ronde began planning for a larger 80-ton vessel to travel Lake Huron from the Sault. De la Ronde's fortune was all but assured.

De la Ronde, perhaps blinded by future wealth, failed to take into account the volatile politics of the region, and the first mining attempt on Lake Superior by a European came to a sudden end. At this point in time in the western Great Lakes, a border war raged between the Ojibwe and Dakota peoples, and the community at La Pointe sat right in the middle of it. Forced to flee, de la Ronde and his men took with them all the ore they could manage. After hostilities cooled, de la Ronde spent the next few years planning a return to Lake Superior, but died before it could become a reality. With de la Ronde's death, France's interest in Great Lakes copper waned. After the Seven Year's War, which France lost to the British, it all but ended. ${ }^{24}$

The British now controlled the western Great Lakes, and it was they who would make the next foray into Lake Superior copper mining. They wasted no time attempting mining operations of their own following the acquisition of the Great Lakes region. Three years after the Seven Year's War, Englishman Henry Bostwick, with the aid of a French guide name Jean Baptiste Cadotte, believed they could pick up where de la Ronde left

\footnotetext{
${ }^{24}$ Louise Phelps Kellogg, The French Regime in Wisconsin and the Northwest (Madison: State Historical
} Society of Wisconsin, 1925), pp.351-358. 
off. They explored and found samples of native copper near the Ontonagon River, and returned to England in order to have them assayed. Buoyed by promising results, Bostwick, along with partners Alexander Baxter and Alex Henry, received a charter from King George III for all mineral rights on Lake Superior in 1769. Baxter left immediately for America, and upon reaching the Sault built a fort, an assaying furnace, and a 40-ton sloop to travel Lake Superior.

By 1771, the newly formed company set to work. Henry and a group of miners returned to the south shore of Lake Superior and began prospecting on the Ontonagon River. Their chosen location, near the great mass of copper known as the Ontonagon Boulder, looked like a sure thing. Henry claimed the giant boulder weighed, "no less than 5 ton. Such was its pure and malleable state, that with an axe I was able to cut off a portion, weighing a hundred pounds." They also found metal imbedded in the rock of the area with green tinged water issuing from it, indicating the presence of copper, or what the miners called a leader.

Henry left the miners for the winter, confident in their operations. Next spring he sent a boat to the mines with provisions, but it returned mid-June with the entire cohort of miners. They reported that they penetrated forty feet into a hill that winter, but misjudged the firmness of the material they were digging into. Being winter, the miners failed to realize the affect of spring thaw on the rock and soil around them, and never bothered to support the diggings with timbers. The drift eventually caved and the miners believed it too difficult to successfully mine in the area without an increase in men, time, and expense. The next year saw the company move to the north shore, but failure greeted them there too, and in 1774 , the company dissolved, ending copper mining in the region for another 60 years. $^{25}$

\section{American Involvement}

American interest in the Great Lakes and its copper took a while to take hold. Although some believe Benjamin Franklin negotiated the Treaty of Paris (after the

\footnotetext{
${ }^{25}$ Louise Phelps Kellogg, The British Regime in Wisconsin and the Northwest (Madison: State Historical Society of Wisconsin, 1935); Alexander Henry, Travels \& Adventures in Canada and the Indian Territories between the years 1760 and 1776, by Alexander Henry, fur trader (Toronto: George N. Morang, 1901), pp.186-228.
} 
American War of Independence) with an understanding of the region's mineral wealth, the new nation had half a continent to give attention to. ${ }^{26}$ The "Northwest" was just another competing area for exploration and settlement. In 1800, Congress passed a resolution, "respecting the Copper mines on the South side of Lake Superior." The resolution authorized the President to appoint an agent to collect all possible information regarding the copper of the region and whether those lands should be acquired from the native population. Nothing more came of the resolution however, as the English, still stinging from the loss of territory after the American War of Independence, incited hostility among the natives towards the Americans. ${ }^{27}$ It would be another two decades before that interest was renewed again.

On January $14^{\text {th }}, 1820$, Secretary of War John C. Calhoun authorized the governor of the newly formed Michigan Territory, Lewis Cass, to lead a scientific expedition into the western Great lakes. Charged with surveying and documenting the geography and geology of the area in order to gain a better understanding of the Northwest, the 124-day expedition also searched for the source of the Mississippi River in order to formalize the border with Canada. Cass, joined by 41 other soldiers, scientists, and native Americans, included the respected geologist Henry Schoolcraft, who afterwards became the first American to tout the mineral wealth of Lake Superior.

Schoolcraft, coming off a successful prediction of the existence of lead deposits in Missouri, struck Cass as a man of industry and ambition. In early spring, the expedition party made the journey up the Ontonagon River to the site of the British mining attempt made 50 years earlier. After hearing incredible tales of the Ontonagon Boulder's size, Schoolcraft was interested in examining it (Fig. 1-4). He found it to be much smaller than he anticipated, and believed it must have fallen down from a bluff to its present location

\footnotetext{
${ }^{26}$ Lawrence T. Fadner, Fort Wilkins, 1844, and the U.S. Mineral Land Agency, 1843 (New York: Vantage Press, 1966), p.ix.

${ }^{27}$ Jacob Houghton, Reports of William A. Burt and Bela Hubbard, esqs., on the Geography, Topography and Geology of the U.S. Surveys of the Mineral Region of the South Shore of Lake Superior, for 1845, ed. J. \& Bristol, T.W. Houghton (Detroit: C. Wilcox, 1846), p.18.
} 


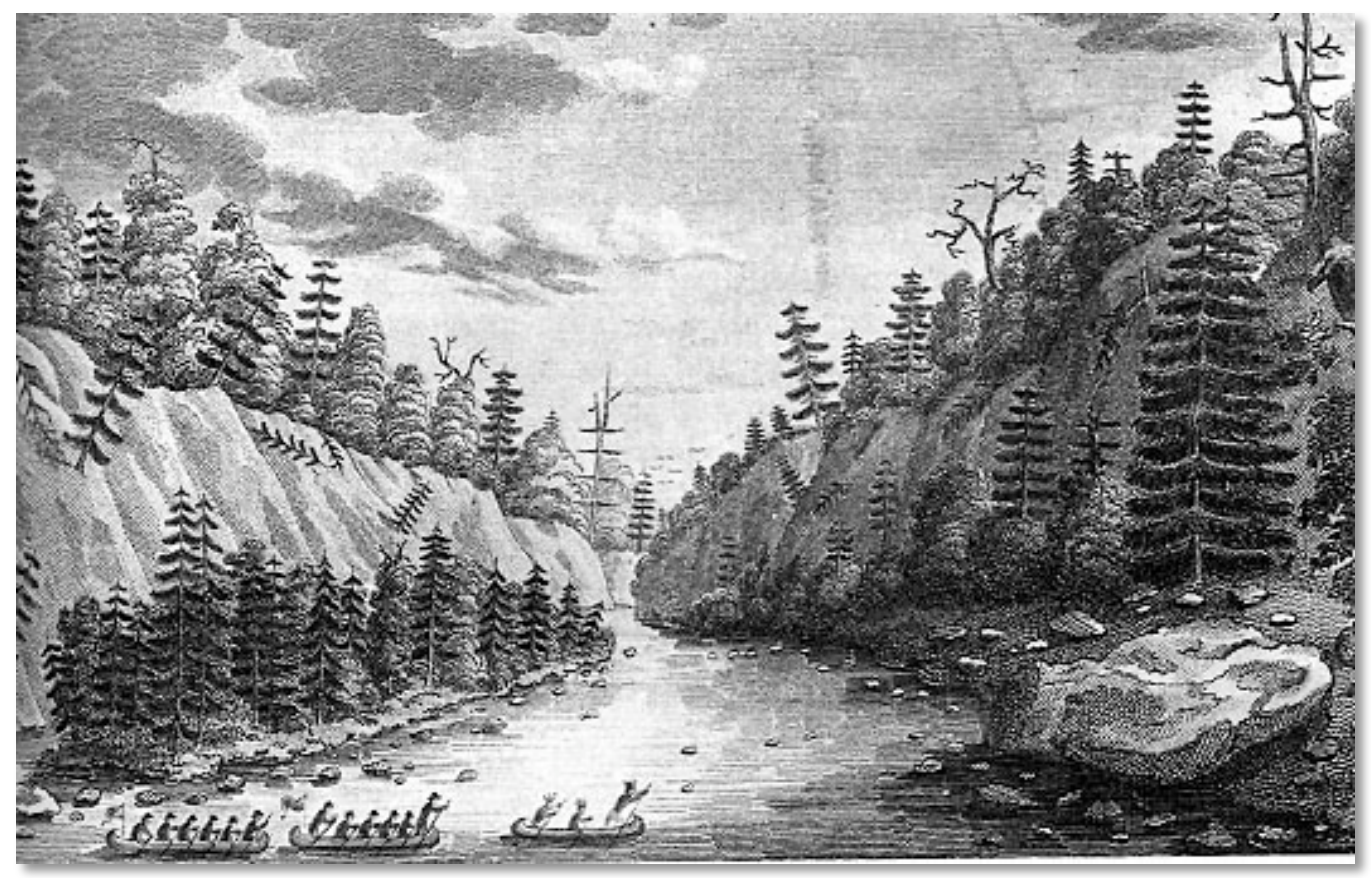

Fig. 1-4. Engraving of Cass expedition'to the Ontonagon Boulder. (Image from Schoolcraft, 1997)

on the riverbank. Schoolcraft noted other indications of copper along the south shore, and in a letter to Secretary Calhoun written the following year, outlined the various ores suitable for assay and possible mining. ${ }^{28}$

Schoolcraft's account of native copper put the wheels in motion for the copper fever that spread to the Keweenaw over the next two decades. One of the responsibilities of the Cass expedition was to procure lands from the native population in order to establish forts to protect future settlement. The area may have been considered American territory, but for all intents and purposes, they had little control over the Lake Superior region. In order for America to gain access to the copper, it needed to obtain the land from the current holders, the Ojibwe.

The first step in gaining the rights to the minerals of Lake Superior came in 1826, with the signing of the Treaty of Fond Du Lac, between the United States and the

\footnotetext{
${ }^{28}$ Henry R. Schoolcraft, Narrative Journal of Travels through the Northwestern Regions of the United States: Extending from Detroit through the Great Chain of American Lakes to the Sources of the Mississippi River, Performed as a Member of the Expedition Under Governor Cass in the Year 1820 (Albany: E. \& E. Hosford, 1821), p. 171; Henry R. Schoolcraft, Account of the native copper on the southern shore of Lake Superior (Oshkosh: R.L. Fox, 1997), pp.202-216.
} 
Chippewa Nation (Ojibwe). Article III of the treaty states, "The Chippewa tribe grant to the government of the United States the right to search for, and carry away, any metals or minerals from any part of their country. But this grant is not to affect the title of the land, nor the existing jurisdiction over it." Americans now had access to the copper, but the land lying on top of the copper bearing deposits still belonged to the Ojibwe. ${ }^{29}$ Concerted mining efforts in the area would have to wait, as interest in mining lands that weren't protected by the authority of the U.S. government presented too great a risk. The newly confirmed lead mining districts of Missouri, Wisconsin, and Illinois made the better option for western mining operations, and attention swung away from the Keweenaw for the next few years.

Before copper mining could begin in earnest, a few necessities had to be sorted out. For one, the land needed to belong to the United States. If ownership of the land couldn't be established, any mining venture would be hard pressed to make a profit. Further, the Keweenaw, and the entire Lake Superior region for that matter, was little known beyond the shoreline. A thorough survey of the geology of the area needed to be completed in order to help determine where, in what form, and what quantities copper existed. Without meeting these requirements, copper mining in Lake Superior could never be considered a sound investment.

\section{Opening of the Keweenaw}

One of the first official accounts of the area's geology came after Henry Schoolcraft's second trip to Lake Superior in 1831-32. Taking with him a much smaller expedition than that led by Governor Cass 11 years previous, Schoolcraft hoped to move quickly through the territory with just 11 men. One of these men, a recent graduate of the Rensselaer School in New York by the name of Douglass Houghton, came to be defined by the region. A naturalist and physician by training, Houghton's first trip to Lake Superior began a 15 year association with copper, one that branded him "Michigan's

\footnotetext{
${ }^{29}$ Thomas L. McKenney, Sketches of a tour to the lakes, of the character and customs of the Chippeway Indians, and of incidents connected with the Treaty of Fond Du Lac (Baltimore: F. Lucas Jr., 1827), pp.479-486.
} 
Columbus" on account of his influence on the early development of the mineral districts there. ${ }^{30}$

Although the primary objectives of the expedition dealt with Indian affairs in the region, Schoolcraft and Houghton made several stops along the shore of the Keweenaw in order to examine its geology. Their findings, unnoticed at the time, correctly identified the origin of native copper. Camping at Hays Point on Copper Harbor, the location of $L a$ Roche Verte, Houghton noted the presence of black oxide of copper within the vein as it moved inland. Travelling southwest from Copper Harbor, Houghton also noticed outcrops of native copper in the trap rock formations along the shore. Visiting the Ontonagon Boulder, Houghton considered its odd location along the riverbank, and assumed it had been removed from its original home. ${ }^{31}$

Piecing together the clues found along the way, Houghton reasoned that the boulder must have originated within the trap rock, just like the outcrops seen further up the shore. Therefore the trap formation had to run the entire length of the Keweenaw down as far as the Ontonagon River. At some point, the boulder must have been wrenched free of the trap to end up in its present location. Houghton thus made the first real geological discovery of the area, that native copper existed within the trap rock, and if mining was to occur in the Keweenaw with any hope of success, it must be in the trap rock that future attention would have to be paid. ${ }^{32}$ Whether or not its existence would be primarily in oxide or native form would be left for others to find out.

Future attention to the area took a back seat as Michigan tackled the issue of statehood. Many in Michigan saw a small strip of land to the south, centered on the port of Toledo, as integral to the future state's success. Due to Schoolcraft and Houghton's findings over the previous 15 years, others in Michigan felt that the Upper Peninsula would be a more promising addition to the new state's boundaries. Ohio also wanted the "Toledo Strip," and after much debate (almost to the point of armed conflict), Michigan's

\footnotetext{
${ }^{30}$ Lawrence T. Fadner, Fort Wilkins, 1844, and the U.S. Mineral Land Agency, 1843 (New York: Vantage Press, 1966), p.x.

${ }^{31}$ Henry R. Schoolcraft, Narrative Journal of Travels through the Northwestern Regions of the United States: Extending from Detroit through the Great Chain of American Lakes to the Sources of the Mississippi River, Performed as a Member of the Expedition Under Governor Cass in the Year 1820 (Albany: E. \& E. Hosford, 1821), pp.287-292.

${ }^{32}$ Ibid. pp.287-292.
} 
admittance to the Union finally came in 1837 without Toledo but instead with the potentially mineral-rich Upper Peninsula. ${ }^{33}$

Anticipating a rush of new settlement, the newly formed government of Michigan immediately called for a comprehensive geological survey of the state. Douglass Houghton, a natural pick to lead the survey, was named state geologist barely a month after Michigan's admittance to the Union. Due to the size of the new state and where people were settling, Houghton's first 3 years as state geologists focused on the Lower Peninsula and the immediate vicinity of the Sault. The need to make it further westward into the Upper Peninsula, into copper country, was well recognized, but settlement patterns and the state's wishes for a steady supply of salt dictated the area's neglect until 1840.

The 1840 field season brought Houghton back to the Keweenaw for the third time. Accompanied by brothers Bela and Fred Hubbard, Douglass' cousin Columbus C. Douglass, and Charles W. Penny, the group arrived mid-summer, and went about surveying the geology that first drew Houghton's interest nine years earlier. Camping at Copper Harbor, Houghton mapped Hays Point, noting native copper outcrops and $L a$ Roche Verte, and blasted samples free from it to take back for further analysis. As summer continued, another visit to the Ontonagon Boulder and several other native copper veins near the Eagle River provided Houghton with enough samples to make the 1840 season the most productive yet in the understanding of the copper country. ${ }^{34}$

Houghton's report the following year would become the guiding light for the copper rush about to descend on the Keweenaw. Houghton's findings outlined in specific terms where mineral explorations could take place, commenting that native copper appeared to be more prevalent in compact rock, not that of a soft or cellular nature. Houghton also discussed similarities between the district and Cornwall, but when it came to describing the ores of the district, he remarked that

\footnotetext{
${ }^{33}$ Charles R. Tuttle, General History of the State of Michigan: with Biographical Sketches, Portrait Engravings, and Numerous Illustrations (Detorit: R.D.S. Tyler, 1873), pp.448-479.

${ }^{34}$ Bela Hubbard, Memorials of a Half-Century in Michigan and the Lake Region (New York: Putnams' Sons, 1888), pp.21, 52-58.
} 
although oxides of copper are present, no "ores of which sulphur is a constituent have been noticed." 35

Houghton felt there was little doubt the district would, "eventually prove of great value to our citizens and to the nation," ${ }^{36}$ but feared, "that it may prove the ruin of hundreds of adventurers, who will visit it with expectations never to be realized. ${ }^{37}$ There was simply not enough hard data available about the district and a lack of infrastructure to ensure success. It didn't matter. Houghton's attempts at caution fell mostly on deaf ears. The "Copper Report" of 1841 heralded a copper rush to the Keweenaw, hard data and infrastructure be damned.

By 1843, the copper rush to the Keweenaw began in earnest. In February of that year, Congress ratified the Treaty of La Pointe, which finally ceded all Native lands from the Chocolay River (near Marquette, MI) west to the head of Lake Superior (near Duluth, $\mathrm{MN}$ ) in exchange for promised annuities in equipment and improvements (Fig. 1-5). The treaty's ratification meant that the Keweenaw and its minerals were the property of the United States, and by April of that year, General Walter Cunningham was appointed agent for the copper lands. ${ }^{38}$

Previously in charge of the lead mine district agency in Galena, IL, Cunningham was given authorization to grant leases and permits for mining and smelting on the peninsula. Cunningham set up a land agency office on Porter's Island, just a few hundred yards from Hays Point, and began issuing one-year mining permits covering 3 square miles. For convenience (and without foresight), the War Department decided to also grant permits in Washington D.C., and opportunities for confusion and corruption in the lease/permit system abounded. Permits for the same property were often either granted to different people or the same person twice. Also, the boundaries themselves were rarely accurate, as a proper survey did not take place prior to the establishment of the land

\footnotetext{
${ }^{35}$ Douglass Houghton, Geological Reports of Douglass Houghton, First State Geologist of Michigan, 18371845 , ed. George, N. Fuller (Lansing: The Michigan Historical Commission, 1928), pp. 280.-281, 541-568.

${ }^{36}$ Houghton to Porter, Dec. $26^{\text {th }}, 1840$. In Alvah Bradish, Memoir of Douglass Houghton, First State Geologist of Michigan (Detroit: Raynor and Taylor, 1889), pp.113-116.

${ }^{37}$ Douglass Houghton, Geological Reports of Douglass Houghton, First State Geologist of Michigan, 18371845 , ed. George, N. Fuller (Lansing: The Michigan Historical Commission, 1928), pp.528-599.

${ }^{38}$ Lawrence T. Fadner, Fort Wilkins, 1844, and the U.S. Mineral Land Agency, 1843 (New York: Vantage Press, 1966), p.155.
} 


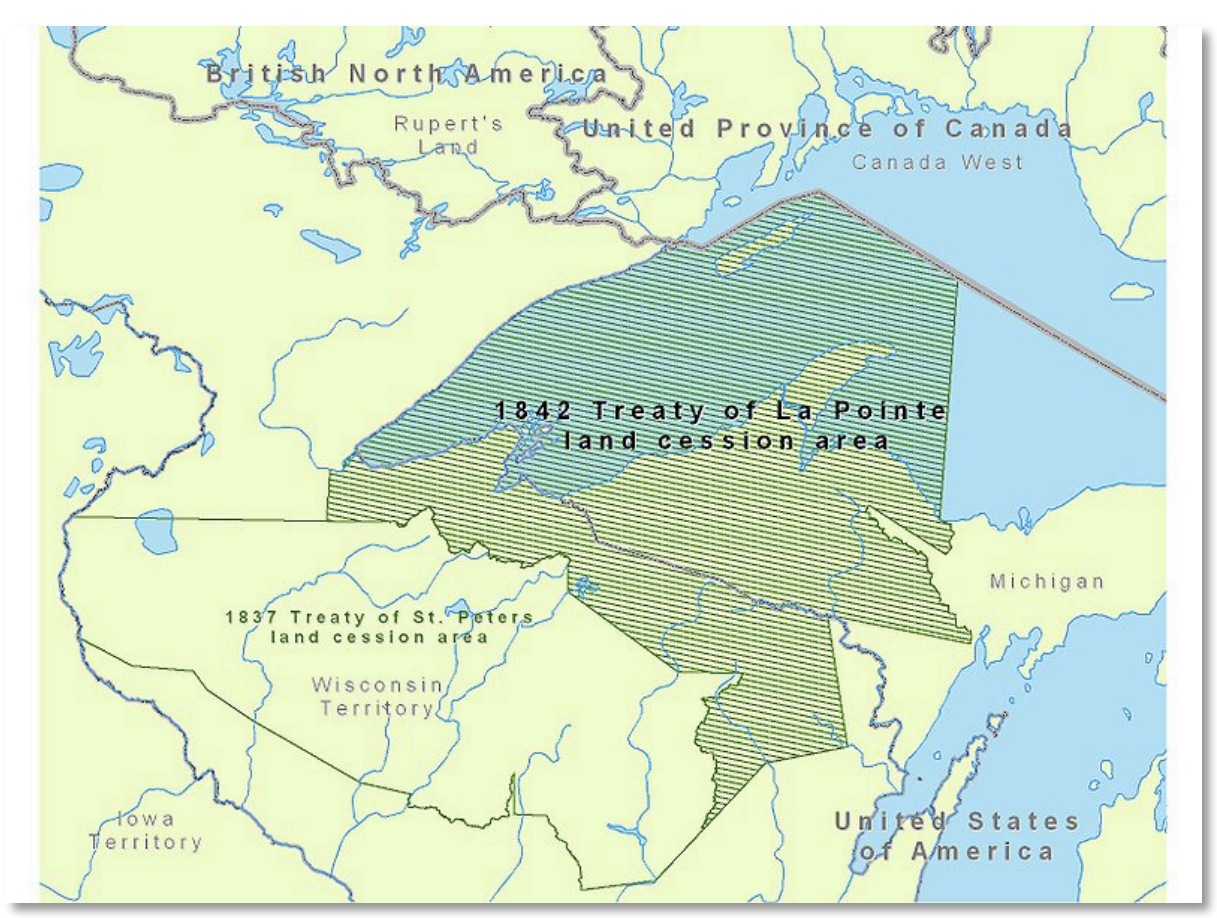

Fig. 1-5. Map showing the 1842 boundaries drawn by the Treaty of LaPointe. (Image from http://en.wikipedia.org/wiki/File:1842TreatyOfLaPointe.jpg)

agency. Inevitably, men arriving in Copper Harbor from Washington with permit in hand often found someone else already working the same ground. In the hopes of curbing corruption, General John Stockton replaced Cunningham in August of 1844. ${ }^{39}$

Corruption may have been tackled with the appointment of Stockton, but confusion still reigned. The original system called for the granting of 1-year, 3 square mile permits, after which one could apply for a 3-year lease on the same land, secured with a $\$ 20,000$ bond. These leases could then be renewed twice more, meaning any one permit holder could conceivably mine a specific property for 10 years. As payment, $6 \%$ of the profits from raised copper would then be remitted back to the land agency. The number of prospectors far outnumbered the available land and by 1845 , the size of permits needed to be reduced to 1 square mile. For all the confusion and corruption, at least 700 permits were still issued in the first 3 years of the program, yet no rental fees ${ }^{39}$ Robert James Hybels, "A Narrative of the Lake Superior Copper Fever, 1841-47," Michigan History June
1950, pp.44-60. 
were collected. This, combined with the ease in which anyone could obtain a permit, forced the government to halt all permitting/leasing by $1846 .^{40}$

In theory, the lease system assured the U.S. government a cut of the profits made in the district. In reality, leasing prevented the kind of investment necessary to explore a property sufficiently and secure a profit. In fact, by 1846 only two operations raised enough ore to demand the $6 \%$ payment to the land agency. Clearly, Houghton's caution was warranted, but for the district to succeed, risk and capital would be required. Therefore, on March $1^{\text {st }}, 1847$, Congress declared the establishment of a new land district for the purposes of selling mineral lands under the rules of pre-emption. Now leaseholders could own their land and minerals in totality. One of these holders was the Pittsburgh and Boston Mining Company, eventual operators of the Cliff Mine. ${ }^{41}$

\section{The Pittsburgh and Boston Copper Harbor Mining Company}

The possibility of making a fortune in the copper country of Michigan lured men of all backgrounds to Copper Harbor in the mid 1840's. Rich and poor alike traveled by land and boat in the hopes of staking a claim in this mostly unexplored wilderness. "Copper Harbor was, at that time, the central point of attraction for all concerned in the mines. All about the harbor, was lined with tents, and every thing was on the move as if the people were driving to a speedy fortune. ${ }^{, 42} \mathrm{~A}$ "copper fever" raged, "The country swarmed with persons...exploring it, and laying permits or making claims.

Quickly...claims were made, companies set up, [and] stock divided into shares. ${ }^{, 43}$ Others profited from the rampant speculation of permits and information that could be overheard in the village's bars crowded with prospectors just returned after weeks of roving in the bush. For a druggist from Pittsburgh, a chance encounter with one of these thirsty prospectors would be the start of a long and profitable enterprise.

\footnotetext{
${ }^{40}$ Ibid, pp.44, 74-94.

${ }^{41}$ Ibid, p. 103 .

${ }^{42}$ Rev. John H. Pitezel, Lights and Shades of Missionary Life: Containing Travels, Sketches, Incidents, and Missionary Efforts During Nine Years Spent in the Region of Lake Superior (Cincinnati: Western Book Concern, 1857), p.156.

${ }^{43}$ Ibid.
} 


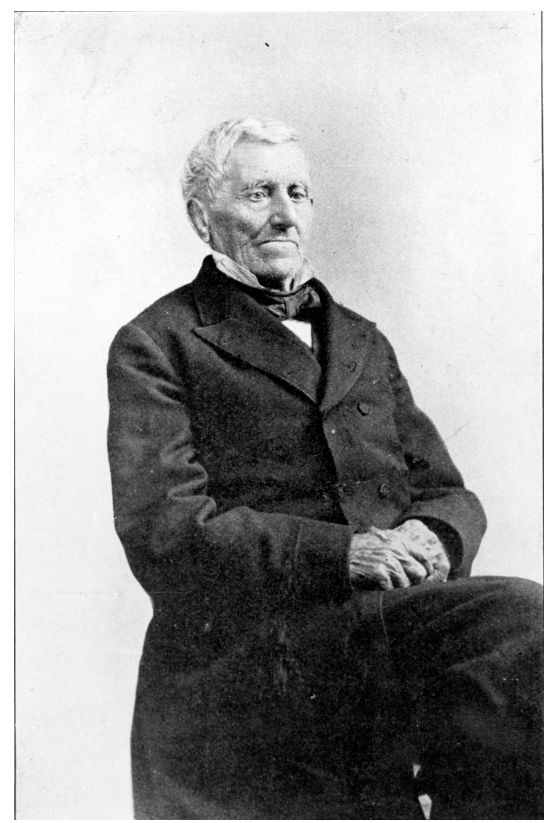

Fig. 1-6. John Hays.

(LD3328H3-4-2, Book

Collection. Michigan Tech

Archives and Copper

Country Historical

Collections)

John Hayes (Fig. 1-6), a one-time pharmacist who longed to leave the city behind and take a chance on adventure, spent his time in Copper Harbor listening and waiting for an opportunity to present itself. Jim Raymond, a Bostonian and one of the first men to file a permit in the district presented Hays with an all too common dilemma in boom-towns; he had, "three of the best god-damned claims on the Keweenaw," but he couldn't, "raise a cent to take the stuff out." 44 Hays, not wanting this chance to slip away, quickly wrote up an agreeent giving he and his Pittsburgh physician and backer, Dr. Charles Hussey, an option to buy a one-sixth interest in the three locations for $\$ 1,000$. Raymond, speaking on behalf of his fellow Boston backers, agreed. ${ }^{45}$

Hays left for Pittsburgh, enthused by the prospect of three bonanzas, and informed Hussey of their new opportunity. Easily won over, an excited Hussey grubstaked Hays one-fourth of all profits made from mining and smelting. They soon realized one-sixth interest wasn't going to be enough if these claims were as promising as advertised, and they quickly sought more backing. Three more Pittsburgh investors, Thomas Howe and Dr. Charles Avery and Dr. William Pettit, each put up another $\$ 1,000$, giving the

\footnotetext{
${ }^{44}$ Angus Murdoch, Boom Copper: The Story of the First Mining Boom (Hancock: The Quincy Mine Hoist Association, 2001), p.50.

${ }^{45}$ Lawrence T. Fadner, Fort Wilkins, 1844, and the U.S. Mineral Land Agency, 1843 (New York: Vantage Press, 1966), p.175.
} 
Pittsburgh contingent a two-thirds control over the locations. The Boston partners either sold outright, as Raymond did, or later traded in their stake in the permits for shares in the company. Formalizing the new arrangement in 1845, the partners created the Pittsburgh and Boston Copper Harbor Mining Company, later dropping "Copper Harbor" from the name once it they realized the fortunes of the company weren't to be found on the harbor, but 20 miles to the west, at Cliff. ${ }^{46}$

The company would come to be defined by these two geographically separated factions. The majority shareholders, Hussey, Avery, Howe and Pettit, all hailing from Pittsburgh, were from the beginning the source of capital and direct financial involvement. The Boston faction, represented by Thomas Jones, Charles Scudder, and George C. Bates (the later of the Isle Royale Mining Co., a successful enterprise in its own right), stayed passively involved, and took a more conservative approach to risktaking. $^{47}$

The property of the newly formed company comprised three leases, each nine square miles in size, numbered 4, 5, and 6 (Fig. 1-7). The company dispatched Professor Forrest Shepherd of New Haven, Connecticut, to examine each and report on their condition. Shepherd reported Lease 4 to be, "the most valuable and interesting of all the locations on Lake Superior." It encompassed the whole of Copper Harbor, including the village, the land agency, as well and the newly constructed Fort Wilkins, which housed military personnel believed necessary to defend miners from the native population. The lease property consisted of uneven land, some good opportunities for waterpower, "a good supply of pine and other timber" and nearly 40 mineral veins of dense, "calcareous spar.",48

Lease 6, located about 26 miles west of Copper Harbor, "commands the whole shore for about four miles; is watered by five small streams or rivulets; and [is] covered

\footnotetext{
${ }^{46}$ Angus Murdoch, Boom Copper: The Story of the First Mining Boom (Hancock: The Quincy Mine Hoist Association, 2001), p.51. And, Donald Chaput, The Cliff: America's First Great Copper Mine (Kalamazoo: Sequoia Press, 1971), p.18.

${ }^{47}$ Pittsburgh and Boston Mining Company. Report of the Committee of the Stockholders of the Pittsburgh and Boston Copper Harbor Mining Company. Boston: S.N. Dickinson and Co., 1847. pp.20, 28-29. ${ }^{48}$ Shepherd, Forrest. Geological Survey of the Mineral Lands of the Southern Shore of Lake Superior, Belonging to the Pittsburgh and Boston Copper Harbor Mining Company. Pittsburgh: George Parkin, 1846. pp.12-14. Calcareous: occuring in limestone.
} 


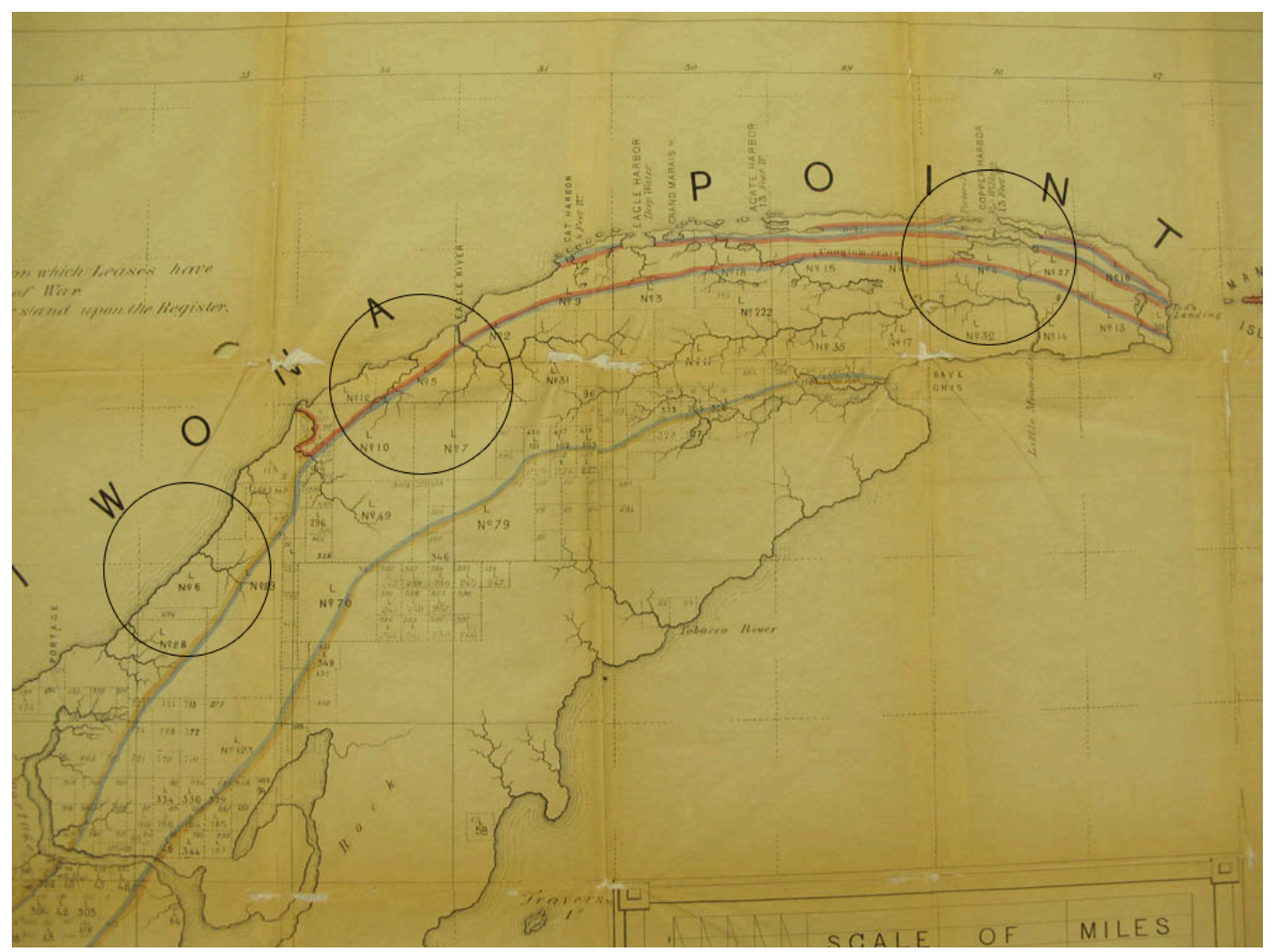

Fig. 1-7. Map of mineral leases on the Keweenaw Peninsula. Leases 4, 5, and 6 of the Pittsburgh and Boston Mining Company are circled from right to left. (Michigan Tech Archives and Copper Country Historical Collections)

with heavy forest of pines, firs, hemlocks, oaks, maples, and cedars." Shepherd's description lacked detail as to the location's mineral prospects, and mainly noted the presence of cultivable land in the south and good building stone along the shore. ${ }^{49}$ Seen as the least promising of the three, the company chose not to renew No. 6 in 1847, as by that time, the their success at Lease 5 made it unnecessary to divide attention between three locations.

"As... not more than one-hundredth part of the tract has been properly explored," Shepherd was unable to heap the same praise on Lease 5 as No. 4, but felt that copper

\footnotetext{
${ }^{49}$ Ibid, pp.11-12.
} 
could be worked, "economically and profitably." ${ }^{50}$ Lying along the shore of Lake Superior at the mouth of the Eagle River, the lease extended southward where,

"The land rises from the lake gradually for about two miles inland, where it obtains an elevation of five hundred feet or upwards, and then suddenly falls about two hundred and fifty feet to form the valley of Eagle River. A heavy forest of oak, maple, birch, hemlock, fir, cedar, white and yellow pine clothes this tract. About two thousand acres of this tract will be arable, and the whole fit either for tillage or pasturage." 51

Using the mines of Cornwall as reference, Shepherd felt the gradual rise and sudden drop provided excellent drainage north and south for any future mining endeavors located there. Describing the geology, Shepherd noted the presence of alternating conglomerate and amygdaloidal trap, traversed by "numerous... broad veins of calcareous spar, yielding more or less of copper." Three veins huddled in the center of the tract had so far been uncovered, the westernmost (named for Hays) and middle veins possessing native copper. ${ }^{52}$ The middle vein would soon garner the most attention, but not until the veins of Lease 4 had been thoroughly explored.

\section{Lease 4: The Workings at Copper Harbor}

Hays, returning to Copper Harbor in the spring of 1844 with eight Pennsylvania coal miners and a German geologist named Alfred Rudolph, began exploring Lease 4 (Fig. 1-8), focusing their earliest efforts on Hays Point, home to La Roche Verte. ${ }^{53}$ Two shafts were sunk on the point, reaching 40 and 60 feet in depth, and contained the black oxide of copper Douglass Houghton noticed fourteen years earlier. The shafts were difficult to keep dry however, and promising news of a discovery at Fort Wilkins drew their attention elsewhere. ${ }^{54}$

\footnotetext{
${ }^{50}$ Ibid, pp.21, 31.

${ }^{51}$ Ibid, p. 19.

52 Ibid, p.20-22.

${ }^{53}$ Angus Murdoch, Boom Copper: The Story of the First Mining Boom (Hancock: The Quincy Mine Hoist Association, 2001), p.51.

${ }^{54}$ Shepherd, Forrest. Geological Survey of the Mineral Lands of the Southern Shore of Lake Superior, Belonging to the Pittsburgh and Boston Copper Harbor Mining Company. Pittsburgh: George Parkin, 1846. p.14.
} 


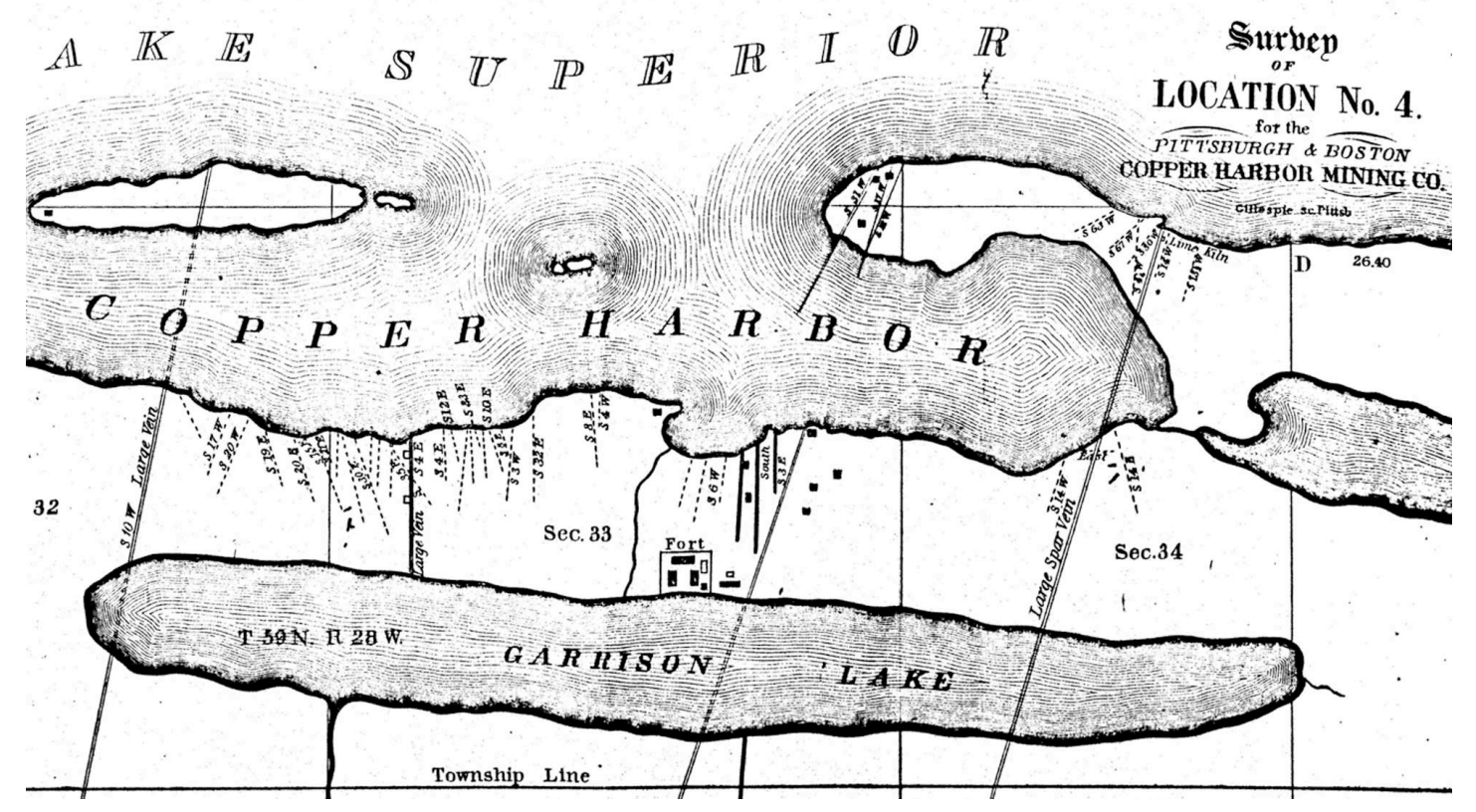

Fig. 1-8. Detail of Location No. 4 from the Geological Survey of the Mineral Lands on the Southern Shore of Lake Superior Belonging to the Pittsburgh and Boston Copper Harbor Mining Company, 1846. Veins and shafts can be seen on Hay's Point (upper center) and just north of Fort Wilkins. Porter's Island (far left) was home to the mineral land agency. (Detroit Public Library, Burton Historical Collection)

Soldiers were prohibited from digging for ores, but one still "managed" to stumble upon some decent sized specimens on the premises, and work soon spread to the grounds around the Fort. Here they hit upon another black oxide vein, and sunk two shafts (possibly a continuation of the Hays Point vein). The oxide ore proved to yield 60$70 \%$ copper, a promising find that led the company to request setting up a smelting furnace on the west side of Lake Garrison (now Lake Fanny Hooe) for their anticipated bonanza. ${ }^{55}$ With building materials already in hand, the mineral land agency offered the company support for the furnace. Fort Wilkins' commanding officer, the final authority in the matter, deemed its intended location, "1000 feet from any of the Buildings of the United States," as still too close to a military installation, and denied the request. ${ }^{56}$ The

\footnotetext{
55 Annual Report (1947). From, Appendix No. 2. February $20^{\text {th }}, 1847$. A letter from Thomas Jones to the stockholders of the Pittsburgh and Boston Mining Co., p.19.

${ }^{56}$ Lawrence T. Fadner, Fort Wilkins, 1844, and the U.S. Mineral Land Agency, 1843 (New York: Vantage Press, 1966), p.172.
} 
furnace materials, their intended use now void, were probably used to build a hearth for the company laborers, whose quarters were set up just a few yards from the Fort. ${ }^{57}$

The furnace refusal should have been seen as a sign. Things at Copper Harbor were not as promising as first believed. Compounds such as the black oxide may be the prevalent form of copper in the Old World, but in the Keweenaw they are a curiosity. In fact, the Copper Harbor area is the only place in the Keweenaw where oxides of copper are found. In most places, copper exists in its pure, metallic state. After 15 feet the black oxide ore ran out, but it took another 105 feet of digging through unproductive ground to convince the company that Lease 4 was a bust.

With little to show for the effort, tensions rose within the company, and on Lease 4. As expenses mounted, the company withheld wages from the miners while it waited for better prospects. Further, William Pettit, another Pittsburgh investor, replaced John Hays as mining agent for the company. According to Sam W. Hill, one of the best known men (and yarn spinners) on the Keweenaw throughout the first decades of copper mining, Hays and his miners threatened Pettit by gunpoint to pay their back wages before Hays would agree to give up his post. ${ }^{58}$ Pettit agreed and the miners received their pay, but the fact remained, the company's luck in Copper Harbor had run out. In all, 30-40 tons of black oxide and native copper were removed from Lease 4 , amounting to $\$ 2,968.70$ in profits. Compared to the nearly $\$ 25,000$ invested by the company, this was an abject failure, and the Copper Harbor workings were effectively abandoned in $1846 .{ }^{59}$

\footnotetext{
${ }^{57}$ Gary W. Van Lingen, The interpretation of archaeological remains at the Pittsburgh and Boston Copper Harbor Mining Company's second campsite: evaluating a structural component and its potential uses and contexts, Thesis, Michigan Technological University (Houghton: Michigan Technological University , 2003).

${ }^{58}$ Western Historical Co., History of the upper peninsula of Michigan: containing a full account of its early settlement, its growth, development, and resources, an extended description of its iron and copper mines (Chicago: Western Historical Co., 1883), pp.134-35.

59 Angus Murdoch, Boom Copper: The Story of the First Mining Boom (Hancock: The Quincy Mine Hoist Association, 2001), p.52.
} 


\section{Chapter 2:}

\section{History of the Cliff Mine}

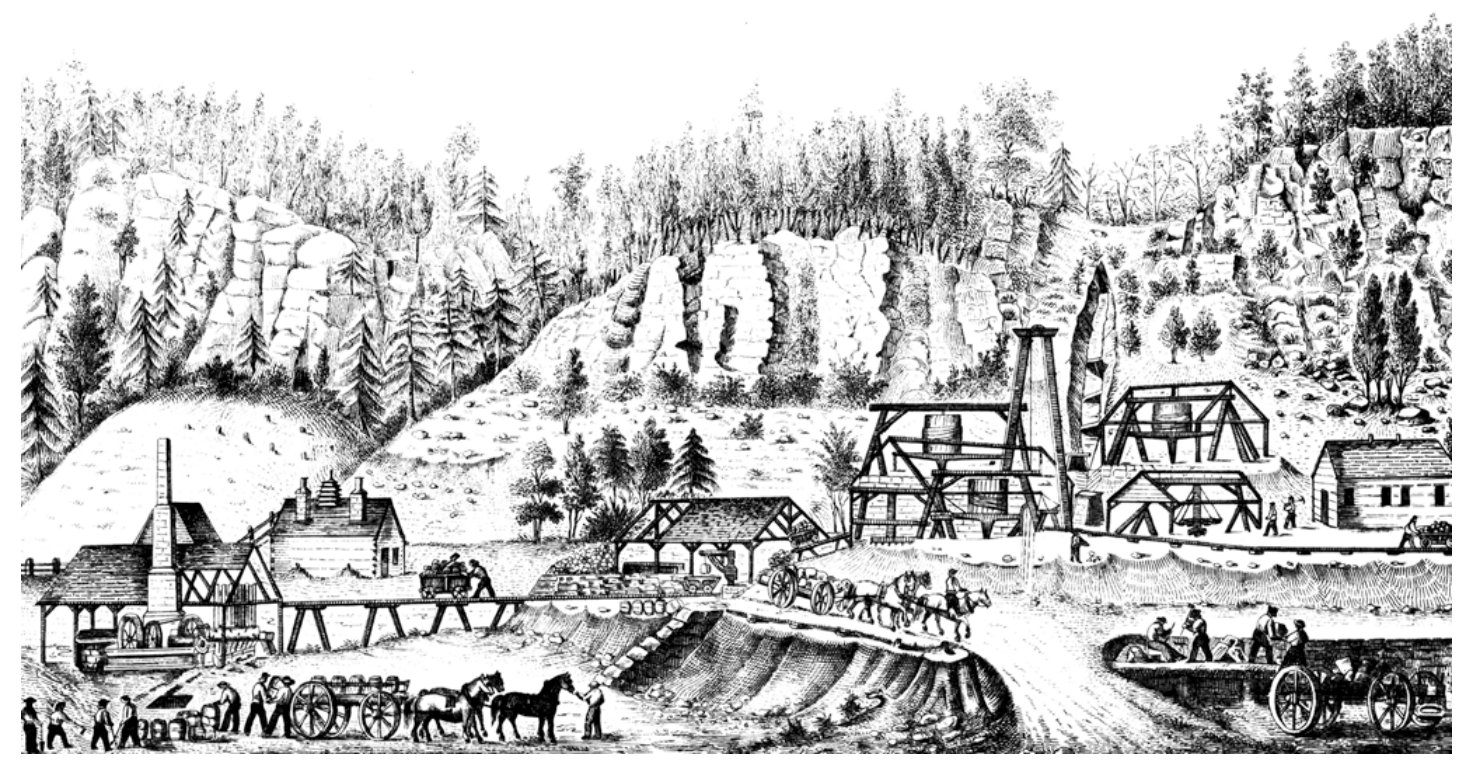

Fig. 2-1. Sketch of the Cliff Mine, 1849. From right to left are seen: the No.'s 1 and 2 Shafts with horse whims, the mineral shed (with crane and a wagon leaving loaded with mass copper), the blacksmith shop, the stamp mill, an men barreling newly separated copper. Behind the shafts can be seen the earliest exposure of the Cillf Vein. (MTU Neg 02619. Michigan Tech Archives and Copper Country Historical Collections)

"On the side of this convulsed and rocky cliff, in the midst of some of these huge rocks, are situated the houses, shops, and works of the miners. There is here no appearance of pleasantness for a village, environed, as it is, with lofty woodland, which intercepts the view in all directions. The office and store joined together is a pretty good building. Some of the dwellings are tolerably comfortable, but not built with regard to convenience or external neatness and order. Necessity has been the rule, and was a good one to begin with, but the Company has opened on a rich treasure, and will probably be disposed to bestow more taste on their future improvements." 57

\section{Lease 5: The Discovery of the Cliff Vein}

A complete and accurate story of the Cliff Mine's discovery may always be unclear, as fact and fiction have intertwined over the years to create many differing

\footnotetext{
${ }^{57}$ Rev. John H. Pitezel, Lights and Shades of Missionary Life: Containing Travels, Sketches, Incidents, and Missionary Efforts During Nine Years Spent in the Region of Lake Superior (Cincinnati: Western Book Concern, 1857), p.14.
} 
versions. What is known is that Jim Raymond first leased the property in May of 1843 and told Hays that it had "pure copper sticking right out of the greenstone." ${ }^{, 58}$ John Hays stated he first found the vein after an exploration of the Lease in the fall of $1844 .{ }^{59} \mathrm{His}$ earlier discussions with Jim Raymond concerning the location and his responsibilities as agent for the company lend credence to this account, but is likely that Hays' simply realized the potential for the location, and didn't find the actual vein that later generated so much wealth. Others have also been suggested as discoverers; the credit for the Cliff's discovery must fall among a group of men exploring the location in the summer of 1845 .

Probably under Hays' orders, a group of German miners under the direction of a "Mr. Cheny" began searching for veins along the shore of Lease 5. They quickly found one and sunk a shaft only to abandon it after it took on water. Cheny and his men followed the vein inland for approximately 3 miles, until they reached the bluff, and found the vein partially exposed and, "a few inches wide, and contained native copper and specks of silver beautifully incrusted with capillary red oxide, with a gangue of Prehnite." ${ }^{60}$ About a foot in thickness at the summit, the vein grew to 5 feet halfway down the cliff face. At the base of the cliff however, the vein completely disappeared. Work commenced immediately, the men sinking a shaft just below the summit and drifting (digging horizontally) a level into the greenstone cliff face to meet it. The vein was found to contain "a small percentage of metallic copper finely disseminated through it," but neither the shaft nor level produced a noteworthy amount. ${ }^{61}$

On the advice of geologists J.D. Whitney and Charles T. Jackson, work moved to the foot of the cliff. Earlier in the summer, the men lost the vein amid the fallen rock and talus littering the cliff base. While clearing the area, the miners uncovered a small mass of copper, and nearby another vein nearly 8 feet wide was located in the granular trap rock. Here, they drove another level into the bluff and at 70 feet, uncovered a huge mass

\footnotetext{
${ }^{58}$ Lawrence T. Fadner, Fort Wilkins, 1844, and the U.S. Mineral Land Agency, 1843 (New York: Vantage Press, 1966), p.175; Angus Murdoch, Boom Copper: The Story of the First Mining Boom (Hancock: The Quincy Mine Hoist Association, 2001), p.53.

${ }^{59}$ Ralph, D. Williams, The Honorable Peter White, a biographical sketch of the Lake Superior iron country (Cleveland: Pention Publishing Co., 1907), pp.10-11.

${ }^{60}$ J.D. Whitney, The Metallic Wealth of the United States: Described and Compared with that of Other Countries. (Philadelphia: Lippincott, Grambo \& Co., 1854), p.276.

${ }^{61}$ Ibid, p. 276 .
} 
of native copper that took days of blasting to break apart. ${ }^{62}$ Fearing the mass an anomaly, the miners continued further into the bluff, and discovered the native copper continued until the trap ran up against the overlying greenstone layer. It appeared as though the P\&BMC had finally struck it rich. The miners soon realized the vein at the summit did not run out as it moved downward, but instead shifted 12 feet to the west, its location determined by the lateral movement of the entire greenstone formation some time in the remote past. ${ }^{63}$ This slide became the natural boundary for native copper within the Cliff Vein, and dictated the operations of the P\&BMC for the next 25 years.

The significance of these findings can hardly be understated. The initial optimism of the copper boom in the Keweenaw began to turn. John H. Pitezel, a visitor to the copper country during its "copper fever" remarked,

"The country swarmed with persons who were exploring it, and 'laying permits' or 'making claims.' If trap rock with veins of quartz was found, it was thought as a good indication of copper. Quickly permits/claims were made, companies set up, stock divided into shares, etc. In many places there was nothing more than a cedar swamp of lake. In others buildings and prospecting occurred. Often capital ran out or the veins gave out and they were abandoned. This was so common that many were beginning to think the Keweenaw was a swindle.",64

The district needed a boost, and the Cliff provided it. Large masses of native, or float, copper had up until this point only ever been found at or near the surface. Douglass Houghton hypothesized the origin of native copper as being within the trap rock years earlier, but Mr. Cheny and his men provided proof. Without a doubt, native copper in the Keweenaw came from the veins and fissures running throughout the peninsula, they were not carried there by ice from Isle Royale as others argued. The discovery renewed interest in the area, and offered hope to the many other mining ventures struggling to keep up

\footnotetext{
${ }^{62}$ Forrest Shepard, Geological Survey of the Mineral Lands on the Southern Shore of Lake Superior, Belonging to the Pittsburgh and Boston Copper Harbor Mining Company (Pittsburgh: George Parkin, 1846), p.23; J.D. Whitney, The Metallic Wealth of the United States: Described and Compared with that of Other Countries. (Philadelphia: Lippincott, Grambo \& Co., 1854), p.276.

${ }^{63}$ Foster, J.W. and Whitney, J.D., Report on the Geology and Topography of a Portion of the Lake Superior Land District. (Washington: House of Representatives, Executive Doc. 69. 31st Congress. 1st Session., 1850)p. 128.

${ }^{64}$ Rev. John H. Pitezel, Lights and Shades of Missionary Life: Containing Travels, Sketches, Incidents, and Missionary Efforts During Nine Years Spent in the Region of Lake Superior (Cincinnati: Western Book Concern, 1857), p.156.
} 
operations. The Keweenaw could be a successful mining district once a mining operation allowed for time, money, and a little luck to co-occur. ${ }^{65}$

\section{The Early Years of the Cliff, 1846-1849}

In the first years of copper mining in the Keweenaw, attention focused on the fissures running perpendicularly to the trap ranges that formed the peninsula. These fissures often contained veins of mineral bearing quartz, and outcrops of these veins guided the earliest prospectors on the peninsula. Following traditional mining methods from brought over from Cornwall, Wales, and Germany, miners went about excavating these veins in the hopes of hitting a seam of native copper. At the Cliff, where operations lay at the base of the 250 -foot bluff, initial workings concentrated on drifting horizontally into the bluff in order to ascertain the nature of the vein. By the end of 1846, the veins vertical orientation revealed itself, and the sinking of a shaft begun. ${ }^{66}$

After finding the first large mass 70 feet under the bluff, mining continued north, moving further and further into the trap that sat under the greenstone slide. At first, the loose trap rock at the base of the bluff meant timber supports were necessary at the entrances of these early drifts. As work moved further under the bluff, the rock hardened, and the $4 \times 6$ galleries required little additional timbering. ${ }^{67}$ Eventually, at approximately 200 horizontal feet, the trap ran up against the greenstone formation, and the copper pinched out. Mine work from here on out needed to follow the vein downward before more northward drifting could be undertaken.

Producing vein or not, developing the mine and sinking the shaft (christened the No. 1) required more working capital. The company started out with $\$ 110,000$ but abandoning Copper Harbor and establishing permanent workings at the Cliff meant the company's expenses for 1846 exceeded $\$ 88,000$, while the balance in favor of the mines

\footnotetext{
${ }^{65}$ J. Fisher, Historical Sketch of the Lake Superior Copper District (Houghton: Michigan College of Mines, 1924), p.242.

${ }^{66}$ Lake Superior News 12 Sept. 1846. At this time the paper was published out of Copper Harbor, MI. It would later be renamed the Lake Superior News and Mining Journal and be published out of Sault Ste. Marie.

${ }^{67}$ Charles T. Jackson, Report on the geological and mineralogical survey of the mineral lands of the United States in Michigan, U.S. Congress, Senate Exec. Doc. 1 (Washington, 1849), p.465.
} 
came to only $\$ 599.55 .^{68}$ In early 1847 , the board of directors met to tackle the question of the future of the mines and company. Either the mines would continue work with the capital on hand or an additional assessment of stockholders would fund expanded operations. Either option came with risks, but the Boston contingent felt additional assessments would lead to potential bankruptcy, and refused to pay. ${ }^{69}$

Dr. Avery, a one-fifth owner of the company, believed in the potential of the Cliff, and felt it more than covered the risk of a stock assessment. It seemed to Avery that the Bostonians were giving up on the Cliff too easily, and looked to the mines of Cornwall to make his case. Alfred Rudolph, the same German geologist who first explored Lease 4 with John Hays two years earlier informed Avery that the mines of Cornwall often didn't become profitable until they reached at least 800 feet in depth. At this time, the Cliff hadn't even reached 100 in depth, and to give up now would be foolish.

The Boston shareholders didn't budge, and Avery took on the risk and future of the company himself. Knowing he had $\$ 82,000$ in credit, he pledged all but $\$ 2,000$ to the company in order to continue operations at the Cliff. Of this, Avery set aside $\$ 60,000$ as a loan in order to sink the mine as quickly as possible. Many stockholders couldn't align themselves with Avery's gamble, and sold off their stock below cost in the coming months. It turned out to be their loss however, as Avery's risk taking proved the correct decision. Within 18 months, the mine repaid the $\$ 60,000$ and began profiting $\$ 20,000$ a month. The P\&BMC stock soared to $\$ 300.00$ a share, and by 1849 the Cliff Mine became the first mine in the copper country to offer a dividend to its stockholders. ${ }^{70}$

The Boston investor's worries may have been wrong, but they weren't unfounded. In the mid to late 1840 's, only one other mining operation dared to gamble on the Keweenaw, and all they ever managed to raise was hope. Also owned by Boston investors, the Lake Superior Copper Company began sinking shafts in the fall of 1844 .

\footnotetext{
${ }^{68}$ Pittsburgh and Boston Mining Company. Report of the Committee of the Stockholders of the Pittsburgh and Boston Copper Harbor Mining Company. Pittsburgh: George Parkin \& Co., 1847. p.3-4.

${ }^{69}$ J. Fisher, Historical Sketch of the Lake Superior Copper District (Houghton: Michigan College of Mines, 1924), p.244.

${ }^{70}$ Ibid. And, Angus Murdoch, Boom Copper: The Story of the First Mining Boom (Hancock: The Quincy Mine Hoist Association, 2001), p.56.
} 


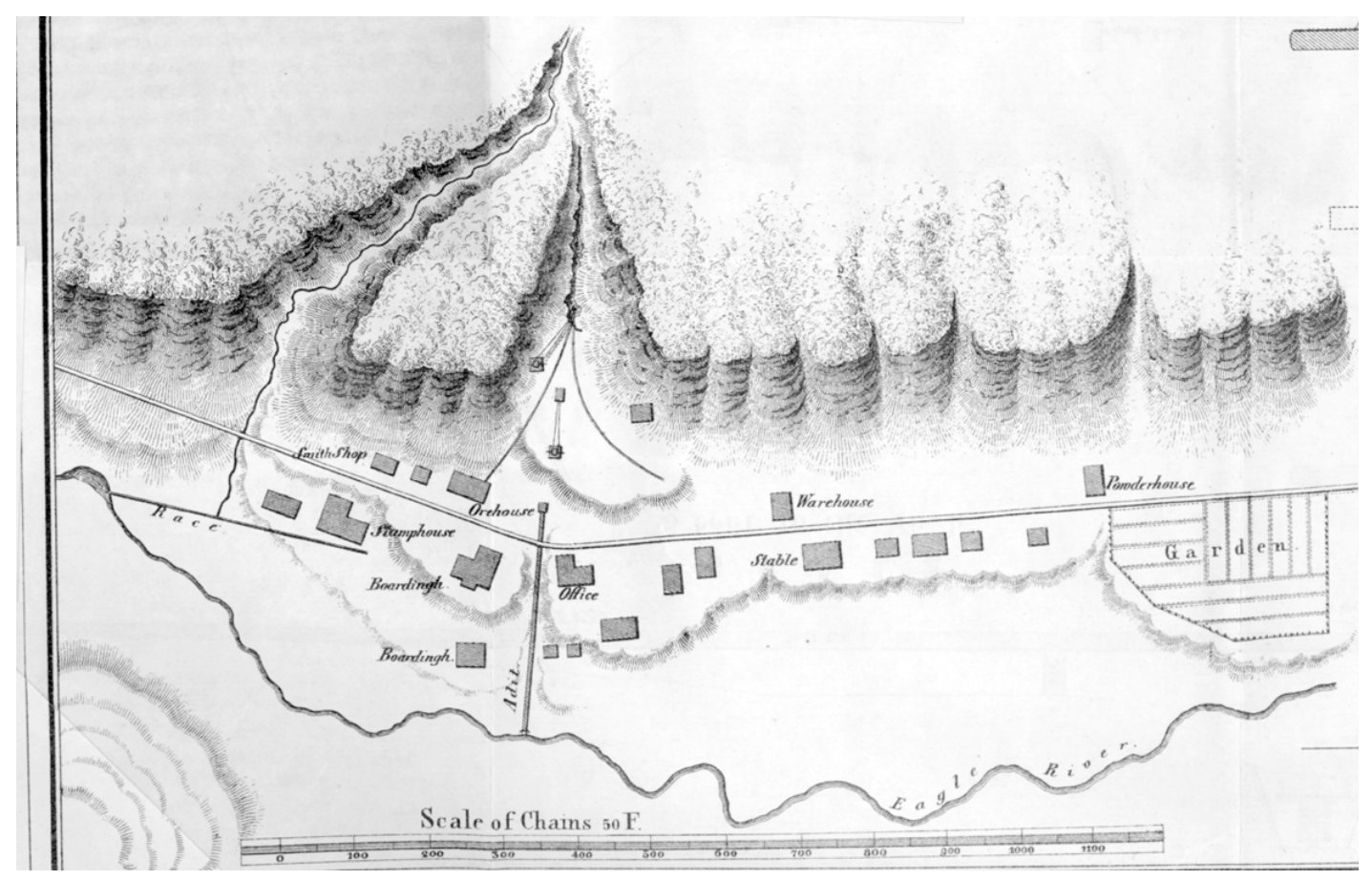

Fig. 2-2. Sam W. Hill's, Topographical and Underground Plan of the Cliff Mine Situated on Keweenaw Point, for Charles T. Jackson, U.S. Geologist, 1847. Shaft's No. 1 and 2 (with whim) lying within the cleft at center. (HD181G8-1849-Pt-3-02, MTU Stacks Book Collection. Michigan Tech Archives and Copper Country Historical Collections)

Located on the Eagle River just a few miles northeast of the Cliff, they were the first to attempt mining in the district. Although initially promising, $(18,000$ pounds of native copper in the first year necessitated the construction of the first stamp mill in the Upper Peninsula), the mine became an investor's nightmare. In less than three years of operation, $\$ 98,790.50$ had been spent at a cost of $\$ 75$ dollars per share (up from an initial investment of \$35). Knowing this, it is hardly any wonder the Boston cohort of the P\&BMC shied away from further increases in funds without a guaranteed payoff. ${ }^{71}$

With new capital in hand, operations at Cliff Mine expanded during 1847. By October, over 100 men were employed as agents, miners, carpenters, blacksmiths, etc. and expenses totaled $\$ 1,000$ a week. $^{72}$ Construction improvements at the mine consisted of erecting a steam engine at the stamp mill and building a blacksmith shop, an office, a

\footnotetext{
${ }^{71}$ Charles E. Wright, Annual Report of the Commissioner of Mineral Statistics of the State of Michigan, for 1880 (Lansing: W.S. George \& Co., 1881), pps. 26-27.

${ }^{72}$ Lake Superior News 2 Oct. 1847.
} 
warehouse, an ore house, a powder house, and boarding houses for the workers (Fig. 22). In order to transport copper out of Cliff, workers put in a corduroy (plank/log) road connecting the mine to the hamlet of Eagle River, located on Lake Superior, and from where copper could be loaded on to one of the vessels supplying the Keweenaw.

The improvements paid off quickly, and the mine shipped over 365 tons of copper by the close of the season. This accounted for $88 \%$ of all copper shipped from the district that year, and didn't include another 300 tons sitting at Eagle Harbor awaiting shipment the next spring. ${ }^{73}$ Along with copper, the vein contained small caches of silver as well, although much of that never made it to market. It is speculated much of the silver from Cliff ended up in the "dinner pails" of miners and stamp mill workers, as nothing in the company's charter laid claim to the silver, only the copper on their property. ${ }^{74}$ Even with the possible pocketing of silver by miners, the mine produced on average $25-50 \mathrm{lbs}$. of silver that fetched $\$ 1,500$ to $\$ 5,300$ annually. ${ }^{75}$

Following recommendations based on the success of 1847 , the board of directors decided to incorporate the Pittsburgh and Boston Mining Company in March of 1848. Capital stock was raised from the original $\$ 110,000$ to $\$ 150,000$, but the number of shares remained the same at 6,000. As per their By Laws, a president, secretary, and treasurer were chosen with Dr. Charles Avery elected the former (a clear recognition of his foresight the year before) and Thomas Howe both secretary and treasurer. The State of Michigan granted the P\&BMC a 30 year charter, not to expire until March of 1878, "for the purpose of mining, smelting, and manufacturing ores, minerals, and metal, in the Upper Peninsula," as well as permission to, "locate, lay down, and construct a rail road from their mines to... any point on Lake Superior which they deem most eligible as a place of deposit and shipment of their ores... and occupy any intervening lands for that purpose, and to take and use...materials as may be required for the construction of the

\footnotetext{
${ }_{74}^{73}$ Ibid. 20 Oct. and 7 Nov. 1847.

${ }^{74}$ Angus Murdoch, Boom Copper: The Story of the First Mining Boom (Hancock: The Quincy Mine Hoist Association, 2001), p.98.

${ }^{75}$ Charles E. Wright, Annual Report of the Commissioner of Mineral Statistics of the State of Michigan, for 1880 (Lansing: W.S. George \& Co., 1881), p.21.
} 
said road." ${ }^{, 76}$ The company, and its mine at Cliff, was now set to become the major player in the Keweenaw for the next 15 years.

\section{Early Mining Practice in the Keweenaw: Working Underground}

One must understand mining practice before continuing with the history of the Cliff Mine since the development of the mine only makes sense in the context of midnineteenth century mining technology. The miners, or more precisely mining agents, coming to the district in the 1840's and '50s's came with Old World, generally Cornish, notions of mining practice. These methods, once adapted to mass copper mines whose nature differed considerably from the tin mines of Cornwall, were quite effective, and continued in use at the Cliff throughout the mine's P\&BMC control.

In the case of the Cliff, vertical shaft mining took place after horizontal explorations proved that the vein's productivity proceeded under the greenstone bluff, not through it, but their early efforts in shaft mining followed known practices. To begin, Cornish practice dictates the sinking of two shafts at roughly the same time, set a fair distance apart, that meet on a vein via a horizontal drift. In the Keweenaw, these two shafts were often begun quite close in order to provide ventilation for the black powder used in blasting. At the Cliff, shaft No.'s 1 and 2 followed this rule, lying less than 100 feet from each other. Vertical shafts were roughly $8 \times 6$ feet and divided into two halves separated by wood planking, one for ladders and descending ropes, the other, for raising and lowering mineral and rock. Shafts were collared with timber supports and a pulley was hung over top. To this pulley was affixed a rope or chain, which was then connected to a large drum, or whim. ${ }^{77}$

The whim was a large perpendicular cylinder with a rope attached that leads down into the shaft. The rope passed over fixed pulleys, called poppet-heads, and was attached to a kibble, or bucket made of $1 / 4$ inch sheet iron, at each end. Driven by horsepower, the cylinder's rotation simultaneously raised one end of the rope and lowered the other with kibbles inside the shaft so that when one kibble was raised to the entrance to the shaft,

\footnotetext{
${ }^{76}$ Pittsburgh and Boston Mining Company. Charter and By Laws of the Pittsburgh and Boston Mining Company of Pittsburgh, Articles of Incorporation (Pittsburgh: George Parkin \& Co., 1848), p.3-5. ${ }^{77}$ Charles T. Jackson, Report on the geological and mineralogical survey of the mineral lands of the United States in Michigan, U.S. Congress, Senate Exec. Doc. 1 (Washington, 1849), p.466.
} 


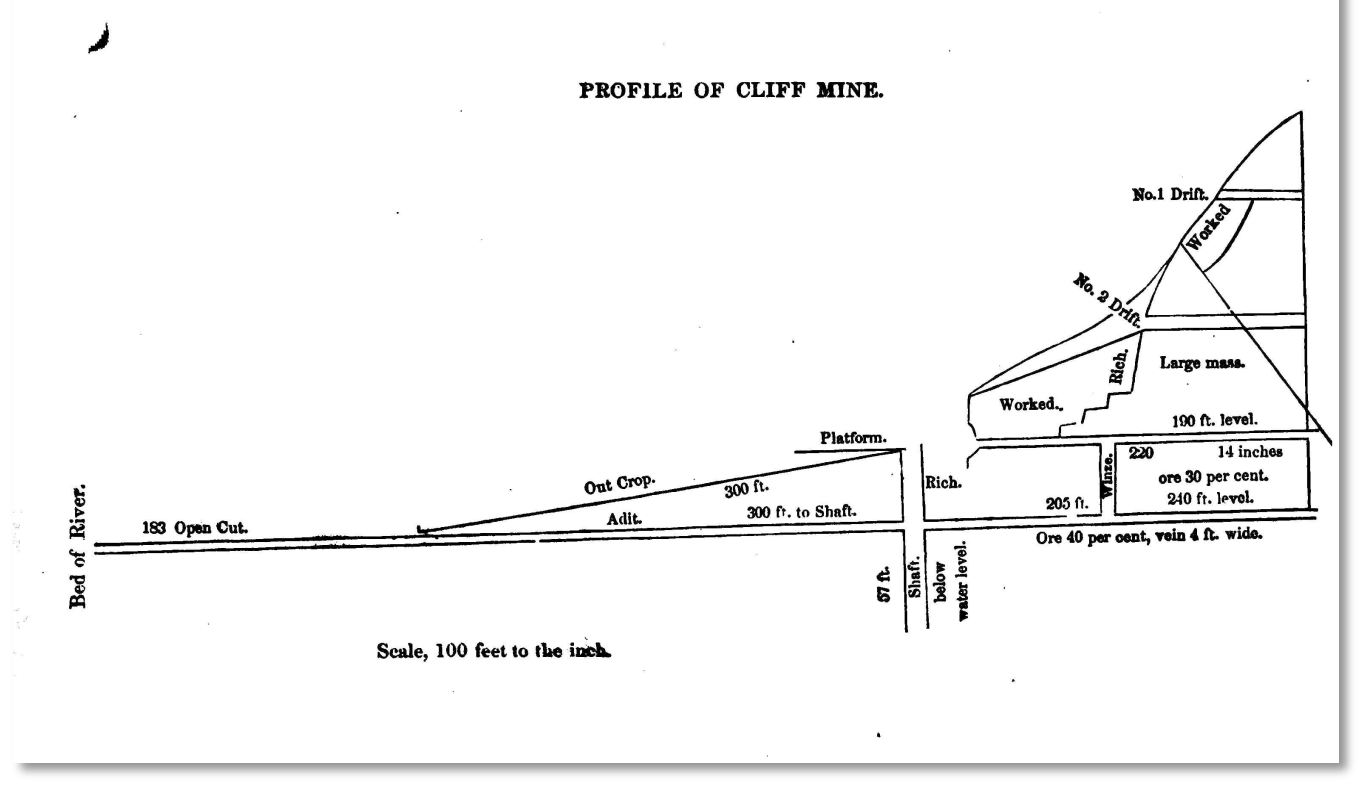

Fig. 2-3. The earliest profile of the Cliff Mine from early 1847. At right are the horizontal drifts (No.'s 1 and 2) into the bluff can be seen as well as the $\mathbf{3 0 0}$ foot adit running right to left from the (at this point) only shaft being worked. (Image courtesy Google Books via University of Michigan)

another was being lowered to the bottom at the same. The raising of large masses of copper at Cliff was also handled via a whim, or sheer, described as "a powerful capstan... with suitable tackle" over the entrance of the main No. 1 shaft, "by which a weight of several tons can be raised., ${ }^{, 78}$

In a corner of the shaft workers placed a 10-inch diameter iron pump, also powered by whim, for the purpose of removing water from the mine. ${ }^{79}$ Along with the water pump, a horizontal drainage level, or adit, was dug to allow water an easy escape from the mine. The adit level at the Cliff extended from shaft No. 1300 feet to the south where it met with the west branch of the Eagle River (Fig. 2-3) ${ }^{80}$ Along with the adit and

\footnotetext{
${ }^{78}$ Rev. John H. Pitezel, Lights and Shades of Missionary Life: Containing Travels, Sketches, Incidents, and Missionary Efforts During Nine Years Spent in the Region of Lake Superior (Cincinnati: Western Book Concern, 1857), p.169-70; J.W. and Whitney, J.D. Foster, Report on the Geology and Topography of a Portion of the Lake Superior Land District. (Washington: House of Representatives, Executive Doc. 69. 31 st Congress. 1st Session., 1850), p.127.

${ }^{79}$ Philip P. Mason, ed., Copper Country Journal: The Diary of Schoolmaster Henry Hobar, 1863-1864. (Detroit: Wayne State Press, 1991), p.82.

${ }^{80}$ Charles T. Jackson, Report on the geological and mineralogical survey of the mineral lands of the United States in Michigan, U.S. Congress, Senate Exec. Doc. 1 (Washington, 1849), p.465.
} 
pumps, the mine's location well above the water table allowed it to stay relatively dry for the first years of its operation. According to the P\&BMC's Annual Report of 1849, the mine only required two hours of draining a day, leaving more time dedicated to raising mineral. ${ }^{81}$

Of course to work in a mine means one must descend into its ever-increasing depths. Before taking the plunge, miners stopped at the dry house in order to change into a work attire of "rough, strong overpants, a large woolen shirt, and a hard round hat or cap of woolen material" hardened with resin. ${ }^{82}$ With a lump of clay they affixed a candle to the hat which they paid for themselves, and attached a few more to their shirt. These candles provided all the light they'd have to work with for their shift underground. Along with their candles, miners also carried in their pocket a "crib," consisting of a Cornish pasty (meat and root vegetables in a crust) and fuses. Finishing off his work kit were drills, hammers, and chisels, which made their way down the shaft via kibble. ${ }^{83}$

Leaving the dry house, miners proceeded to the shaft, where a trap door is all that separates the surface and, "the dark unknown vacuity beneath." ${ }^{\prime 4}$ Ladders placed at 20foot intervals and used for descending and ascending the mine were attached to the surrounding rock with iron staples and bolts. Whether climbing up or down, miners were reminded to, "hang fast with the hands if the feet go to the Devil," as the ladders could be treacherously slippery due to the dampness of the mine. ${ }^{85}$ At the bottom of each ladder was a platform, or sollar, with a manhole for the miner to go through in order to reach the next ladder (Fig. 2-4). ${ }^{86}$

Once down roughly 60 feet, or 10 fathoms, the first level was reached running perpendicular to the shaft. Following along the vein, or in miner's speak, in the country, levels are horizontal drifts spaced vertically every 10 fathoms from which mine work

\footnotetext{
${ }^{81}$ Pittsburgh and Boston Mining Company. Report of the Committee of the Stockholders of the Pittsburgh and Boston Copper Harbor Mining Company. Pittsburgh: George Parkin \& Co., 1849. p.8.

${ }^{82}$ Robert E. Clarke, "Notes from the Copper Region," Harper's New Monthly Magazine March, April 1853: p.446.

${ }^{83}$ Philip P. Mason, ed., Copper Country Journal: The Diary of Schoolmaster Henry Hobar, 1863-1864. (Detroit: Wayne State Press, 1991), p.206.

84 "The Mines and Miners of Cornwall," Lake Superior Journal 2 Sept. 1854.

${ }^{85}$ Robert E. Clarke, "Notes from the Copper Region," Harper's New Monthly Magazine March, April 1853 p.447; Philip P. Mason, ed., Copper Country Journal: The Diary of Schoolmaster Henry Hobar, 1863-1864. (Detroit: Wayne State Press, 1991), p.82.

86 "The Mines and Miners of Cornwall," Lake Superior Journal 2 Sept. 1854.
} 


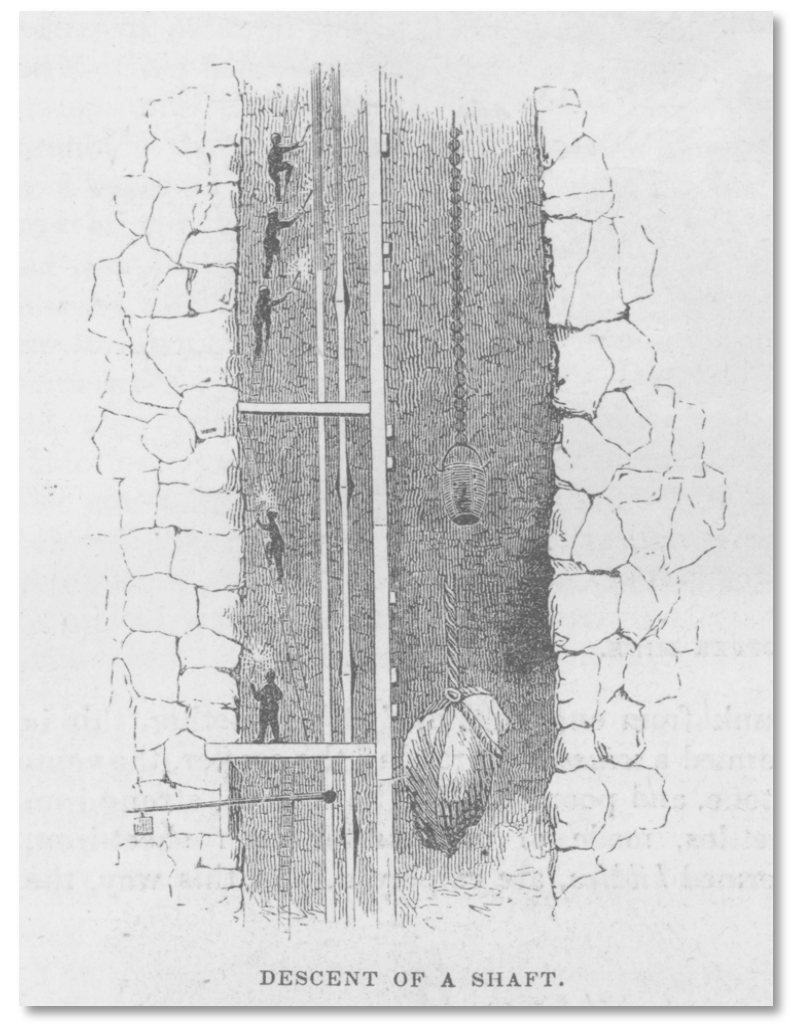

Fig. 2-4. A vertical shaft divided in half; one side for raising kibbles and mass copper, the other for pumps and miners. Miners descend ladders separated by sollars, or platforms. (BookAP2H2v6-447-A, Book Collection. Michigan Tech Archives and Copper Country Historical Collections)

proceeded. ${ }^{87}$ Work commenced upward from one level to another, through the practice of stoping (Fig. 2-5), believed to be the stage of mining necessary to reach in order for a mining venture to move from an exploration to a full-fledged, profitable operation. ${ }^{88}$ Overhead in the drifts, miners first built scaffolding, or stulls, out of large timbers that in effect replaced the drift's ceiling. Mine work occurred above the drift, upward in a steplike, piecemeal fashion with the stulls acting as a new floor. Two or three man teams using hand held hammers and drills bored holes into the rock. Once the holes reached 6 feet in depth, they filled them with black powder and fuse, and blasted the rock down on to the stulls. Here, the rock was sorted in relative darkness; the workers separating the paying ore from the deads (non-mineralized rock) by hand (copper protrusions within veinstone ore are sharp and prickly). Once separated, the veinstone and mass copper was loaded onto wooden trams, which travelled by rail to the shaft and awaiting kibbles,

${ }^{87}$ Rev. John H. Pitezel, Lights and Shades of Missionary Life: Containing Travels, Sketches, Incidents, and Missionary Efforts During Nine Years Spent in the Region of Lake Superior (Cincinnati: Western Book Concern, 1857), p.173.

${ }^{88}$ Charles T. Jackson, Report on the geological and mineralogical survey of the mineral lands of the United States in Michigan, U.S. Congress, Senate Exec. Doc. 1 (Washington, 1849), p.466-67. 


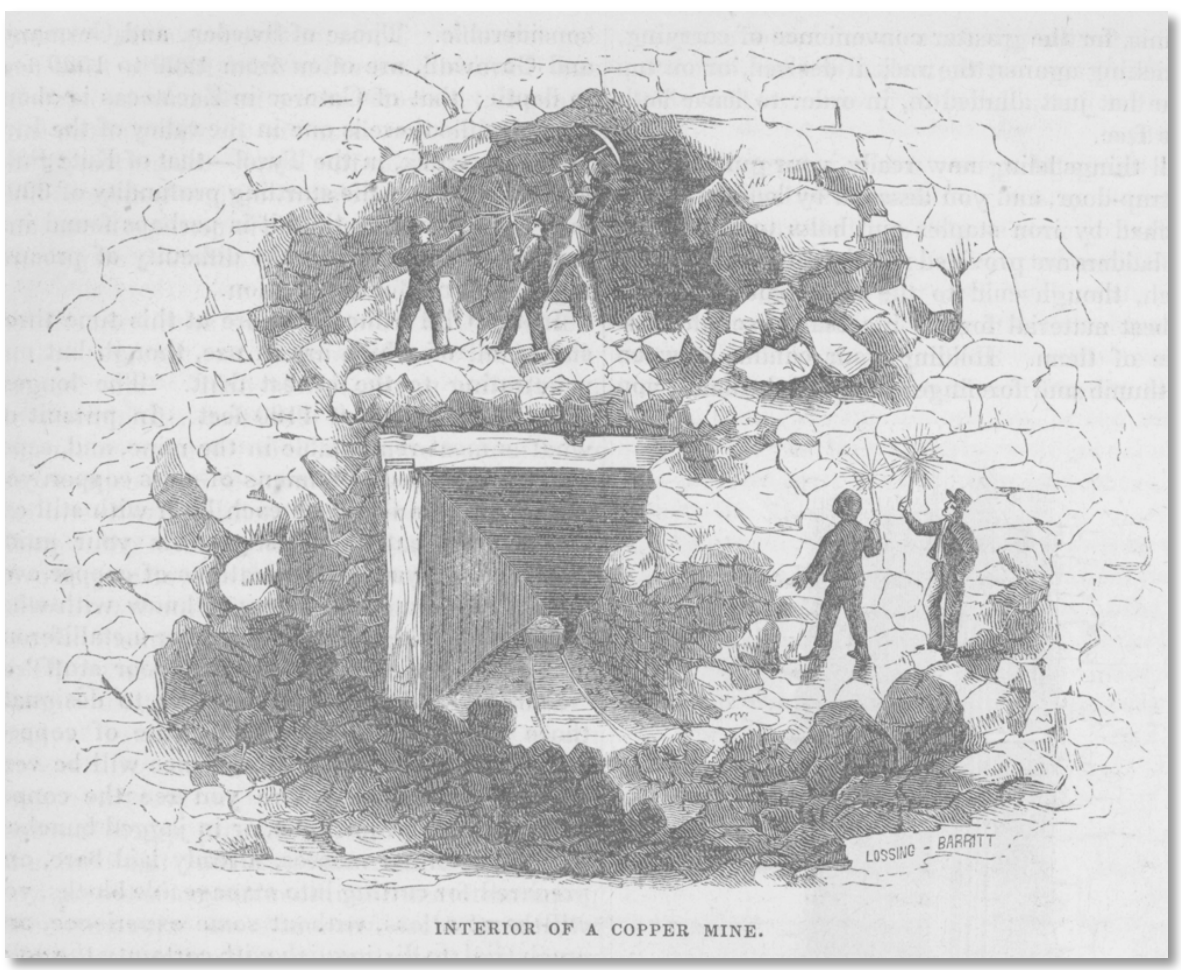

Fig. 2-5. Interior of a copper mine, showing stoping and stulls. (Book-AP2H2v6-448-A, Book Collection. Michigan Tech Archives and Copper Country Historical Collections)

leaving the deads to fill in the drift below and keeping the stulls from collapsing on themselves. ${ }^{89}$

Aside from stoping the veinstone between levels, miners at the Cliff also encountered large, in some cases 60-70 ton, masses of native copper running the length of the vein, "in...irregular, flattened, tubular shape[s]" which accounted for almost $60 \%$ of all the copper sent out from the mine in the early years. ${ }^{90}$ In order to break these masses up, a hall was created behind the mass, and into it kegs of powder are placed and lit. Once dislodged, the mass was worked by cold chisel, 18-24 inches in length where, "A groove or channel is cut diagonally, at a convenient point, where the copper is as pure as possible, and the thickness comparatively small, which is carried through the mass till it is separated into two parts." One person held the $3 / 4$ of an inch wide chisel while another

\footnotetext{
${ }^{89}$ W.R. Crane, "Mining Methods and Practice in the Michigan Copper Mines," Bulletin U.S. Bureau of Mines 1929: p.6.

${ }^{90}$ J.W. and Whitney, J.D. Foster, Report on the Geology and Topography of a Portion of the Lake Superior Land District. (Washington: House of Representatives, Executive Doc. 69. 31 st Congress. 1st Session., 1850), p.181.
} 
struck it with a heavy sledge. This was repeated as the chisel moved laterally across the mass until a piece a few inches long was removed. This time-consuming and costly work (\$6-7 “per square foot of surface cut through") was then continued until the mass was completely severed, the purity of the copper determining the operation's speed. ${ }^{91}$

The division of labor underground at the Cliff followed previous Cornish practice as well. At the top stood the mine agent, Mr. Hanna, who acted as the go-between the board of directors and mine workings. A chief clerk handled the business affairs of the mine including keeping the books and paying the bills. Captains and their assistants then managed the surface machinery and underground workings. Capt. Jennings, the Cliff's head captain in the early years of the mine, acted as manager, engineer, and geologist for the mine, and oversaw all the underground workings. The head captain's expertise could make the all the difference in running an efficient and profitable enterprise. ${ }^{92}$

Under Cornish practice, all underground work was handled through a contract system, with two groups, tributers and tutworkmen, bidding on the paying and nonpaying ground respectively. On the first of the month, setting day, the head captain held an auction for pitches, sections of stoping ground of varying degrees of potential, that tributers would bid on to work in 8 hour shifts. The men were paid on the value of the ore stoped, and wages were tied to market prices. Tutworkmen also worked on contract, only they bid on areas of non-paying ground, called bargains, where shaft sinking and drifting occurred. Unlike tributers, tutworkmen were paid based on the amount of earth removed, measured in fathoms, and their wages depended almost solely on the hardness of the rock they blasted through. ${ }^{93}$

The risk involved in developing early mines in the Keweenaw called for a modification of the Cornish contract system. Paying miners for ore worked could cripple a mine in its early years, as tribute contracts did nothing to ensure the working's upkeep. However the tutwork system (paying by the fathom) put the focus on all workings,

\footnotetext{
${ }^{91}$ Ibid; J. Fisher, Historical Sketch of the Lake Superior Copper District (Houghton: Michigan College of Mines , 1924), p.243.

${ }^{92}$ Larry Lankton, Cradle to the Grave: Life, Work, and Death at the Lake Superior Copper Mines. (New York: Oxford Univeristy Press, 1991), p.59.

93 "The Mines and Miners of Cornwall," Lake Superior Journal 23 Sept. 1854; Pittsburgh and Boston Mining Company. Report of the Committee of the Stockholders of the Pittsburgh and Boston Copper Harbor Mining Company. Pittsburgh: George Parkin \& Co., 1847. p.40-42.
} 


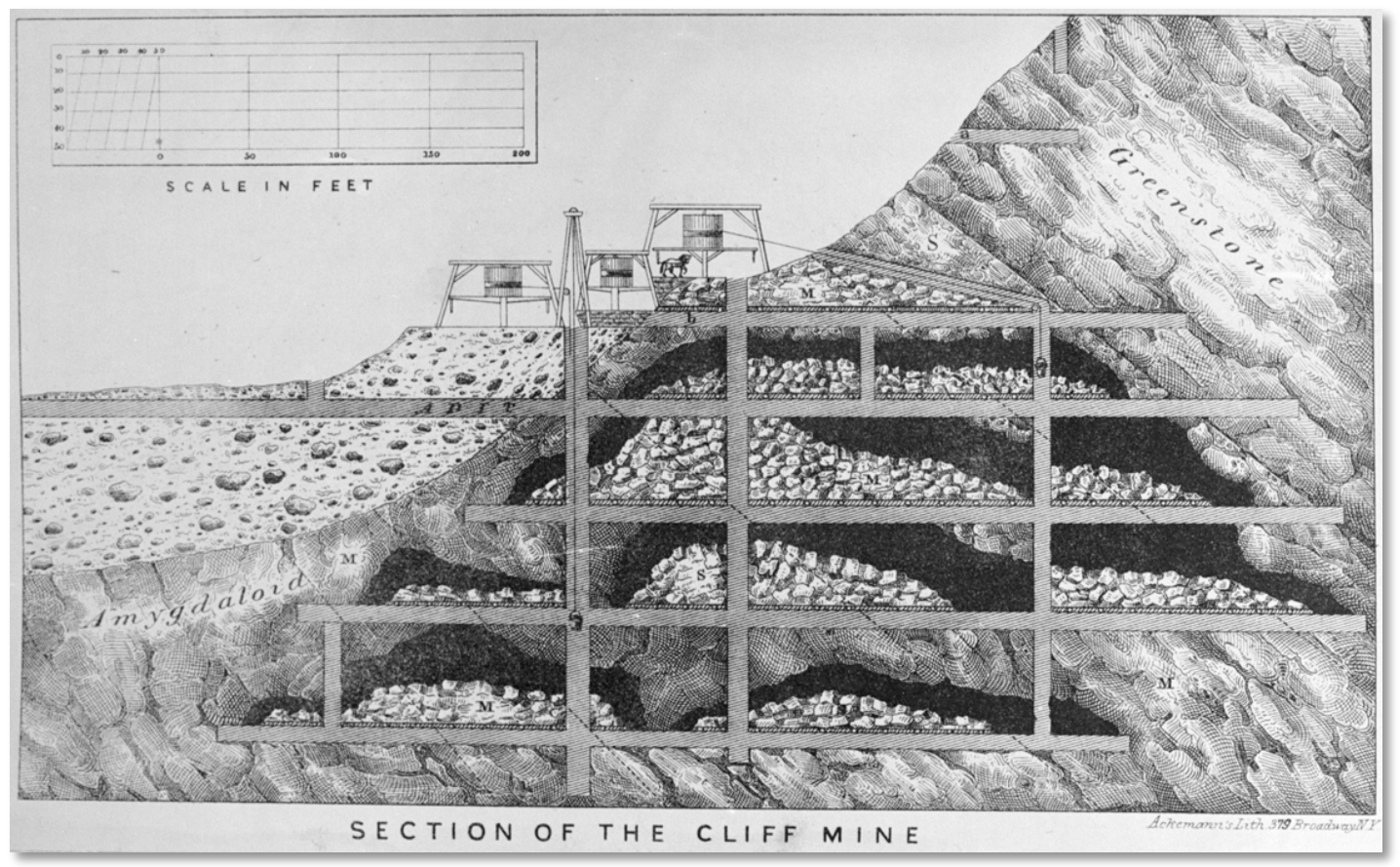

Fig. 2-6. Cliff Mine underground drawing from Foster and Whitney's, Report on the Geology and Topography of a Portion of the Lake Superior Land District. (Washington: House of Representatives, Executive Doc. 69. $31^{\text {st }}$ Congress. $1^{\text {st }}$ Session., 1850). Note the horse whims, stoping, and the deads left for fill. (MS042-028-BB-174B. Reeder Photograph Collection. Michigan Tech Archives and Copper Country Historical Collections)

paying ground or not, and encouraged tidy, well-maintained drifts and levels. Drifts could be left for a time as other areas of the mine were expanded, only to be revisited at a later date, allowing for the expansion of underground workings while keeping wages and costs down. ${ }^{94}$ The wages given by the companies were then used to purchase candles and tools such as hammers, chisels, drills, shovels, powder, and even the ladders used to ascend and descend the mines, so much of the money spent by the company returned to their coffers eventually. Miners also paid for the use of the mining company's machinery, such as kibbles, whim, hoist, and dry house. ${ }^{95}$

\footnotetext{
${ }^{94}$ Lake Superior News 28 July 1848.

95 Larry Lankton, Cradle to the Grave: Life, Work, and Death at the Lake Superior Copper Mines. (New York: Oxford Univeristy Press, 1991), p.66.
} 


\section{Work at the Surface}

As miners freed masses of native copper and ore from the galleries between levels, grass hands on the surface were busy handling those already brought to the surface. From the shaft, these ores were brought via tram to a mineral yard or shed, where they were all further separated. The smaller masses of copper, referred to as barrel-work, were placed into wooden casks capable of holding $800 \mathrm{lbs}$., and awaited shipment. The larger masses at Cliff were also brought to the mineral shed, where they were weighed, stamped with the company's initials, and then raised up via crane and placed on a wagon to be taken to the dock at Eagle River. The remaining veinstone ore was first calcined, or heated until friable, and then brought via tram to the stamp mill in order to separate the copper from any accompanying quartz and rock. ${ }^{96}$

Calcining was necessary in the early years of copper mining as the crushing technology of the time couldn't apply enough force to effectively separate copper from rock. The veinstone was stacked with wood in a three-sided pit (the bluff making up the fourth), 14 feet square, on a bed of cast iron. The piles, sometimes as large as 60 tons, were then set ablaze and allowed to burn to 2-4 days. The roasting rock required careful attention in order to make sure the copper didn't fuse to the rock. Mimicking aboriginal mining techniques, water could be poured on the pile to quench the rock and quartz in order to make them more friable. After the fire was completely out, workers broke up the veinstone with hammers into pieces weighing 2 pounds or less. These smaller pieces of calcined rock were shoveled into a tram and taken to the stamp mill (Fig. 2-7). ${ }^{97}$

The tram was built with a moveable bottom or front piece that when removed, dropped the ore into an inclined pass, a large box about 10 feet in height running behind the stamps. The first stamp mill at Cliff pulverized the rock without the aid of water, but by 1847 the mill incorporated the use of water to help facilitate the separation of copper from the calcined rock. ${ }^{98}$ From the pass flowing water, some of which is provided by

\footnotetext{
${ }^{96}$ Robert E. Clarke, "Notes from the Copper Region," Harper's New Monthly Magazine March, April 1853: p.578.

97 Ibid.

${ }^{98}$ Charles T. Jackson, Report on the geological and mineralogical survey of the mineral lands of the United States in Michigan, U.S. Congress, Senate Exec. Doc. 1 (Washington, 1849), p.434.
} 


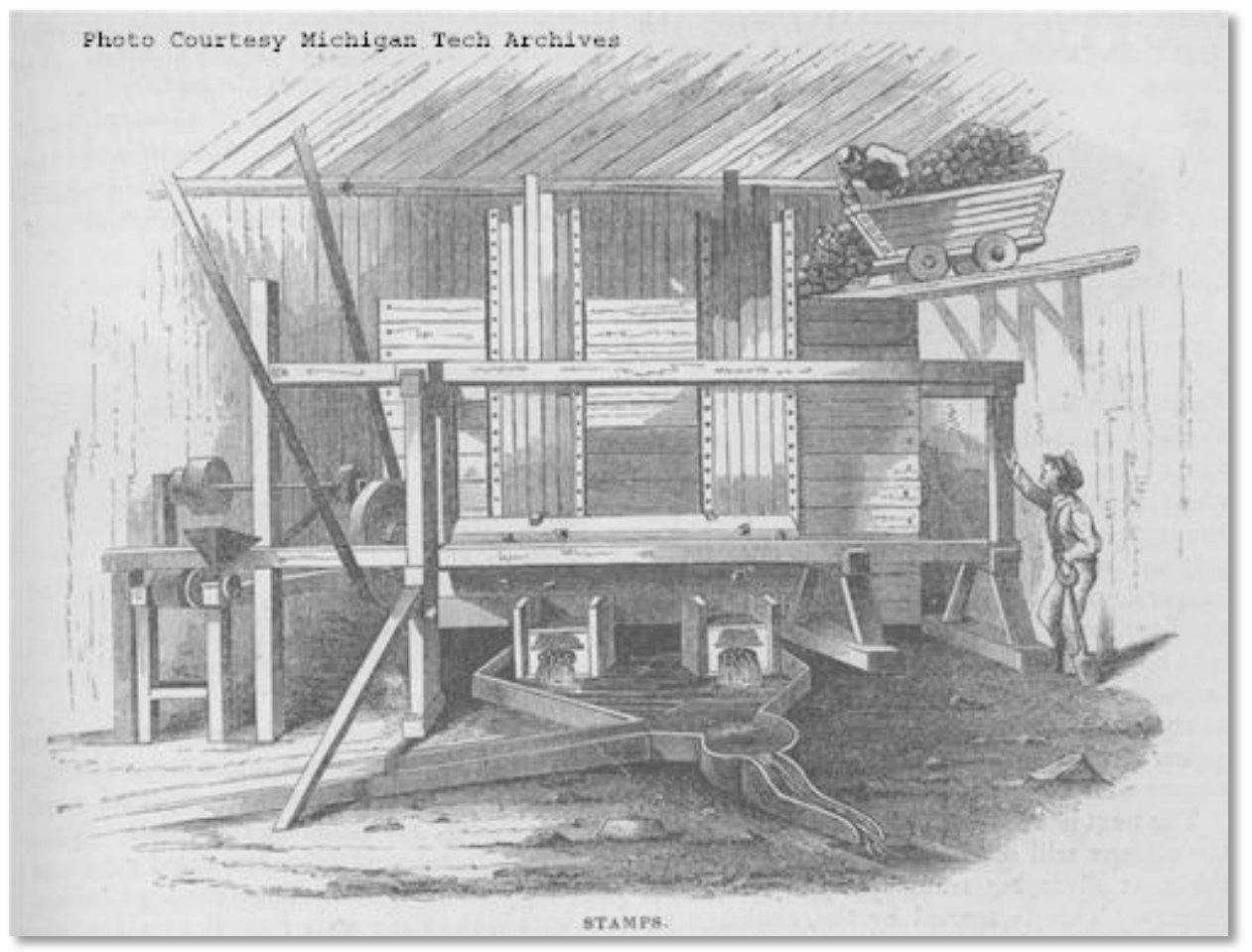

Fig. 2-7. A stamp mill. (Book-AP2H2v6-579-A. Book Collection. Michigan Tech Archives and Copper Country Historical Collections)

draining the mine, conducted the crushed ore under batteries of stamps. ${ }^{99}$ The stamps consist of "several pestles of wood in a vertical position, to which heads of iron, weighing 200 pounds or more, are attached. A cylindrical axle revolves horizontally, and is armed with cams, which, acting successively, catch into the shoulders of the pestles and raise them to the required height, then they are disengaged and fall into an oblong cast iron trough."100

The crushed ore separated within the flow of the water, the heaviest portion moving into a small pool where heavier particles settle to the bottom and the rest is siphoned off to a trough to the left. The copper at the bottom of the pool and the remainder still adhering to the stamps and mortars was collected and barreled. The trough then flowed into pits, where again the heaviest particles separated from the lighter water

\footnotetext{
${ }^{99}$ Robert E. Clarke, "Notes from the Copper Region," Harper's New Monthly Magazine March, April 1853 : p.578.

${ }^{100}$ J.W. and Whitney, J.D. Foster, Report on the Geology and Topography of a Portion of the Lake Superior Land District. (Washington: House of Representatives, Executive Doc. 69. 31st Congress. 1st Session., 1850), p.183.
} 


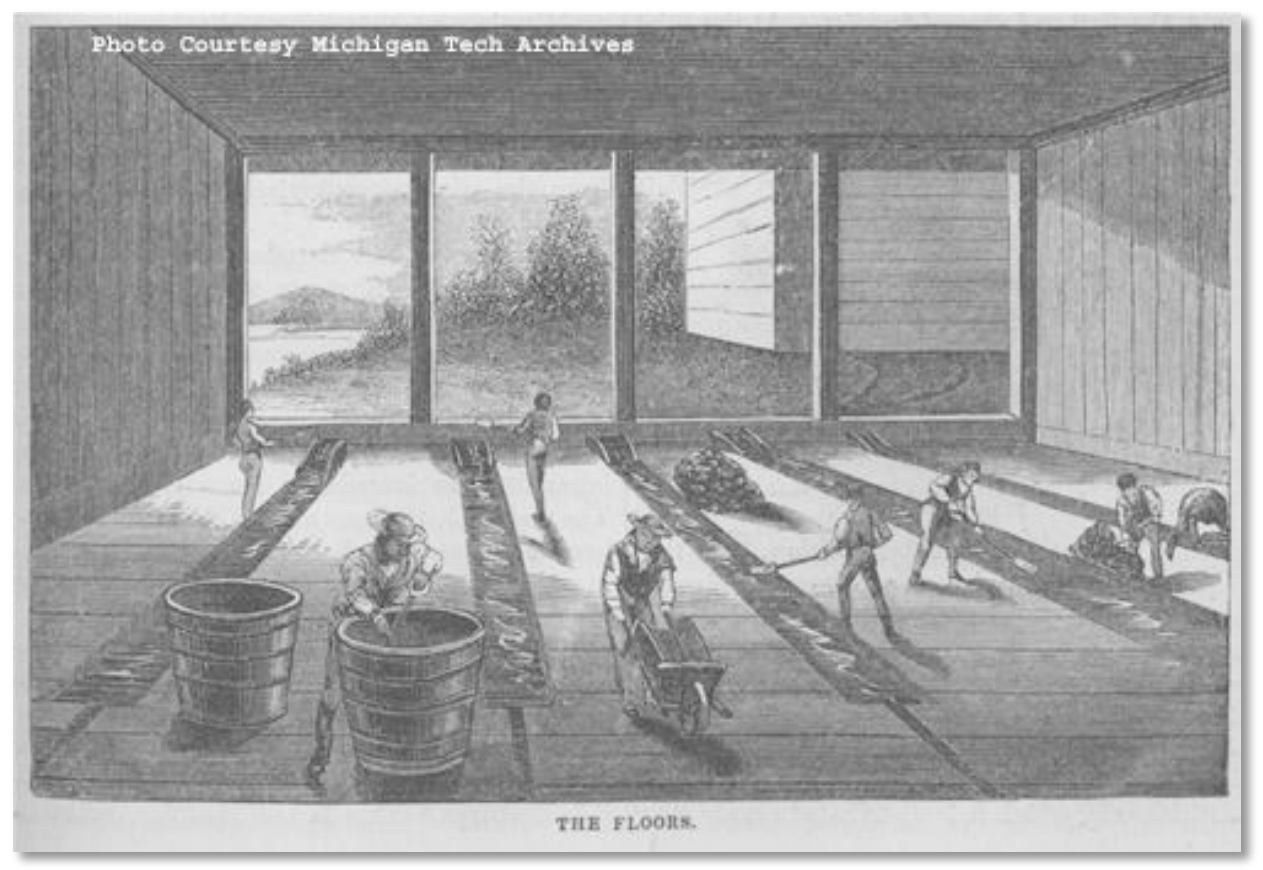

Fig. 2-8. Washing floors. (Book-AP2H2v6-579-A, Book Collection. Michigan Tech Archives and Copper Country Historical Collections)

and particulate. In the early years of Cliff, when stamping only occurred in the warmer months, the pits would fill up in 48 hours. From these pits the top was removed as poor stuff and the remainder was taken to the washing floors where they were sifted and raked to concentrate the copper even more (Fig. 2-8). In the winter, these pits were left to accumulate all season long and their contents could amount to several tons of material once spring arrived, necessitating a second washing floor built just to handle this stockpiled slime. ${ }^{101}$

Finally worker (usually a boy), sifted and raked the solution with a jigger, or perforated brass tub, in order to create a residue of copper particulate at the bottom. The resulting residue was scraped off, heaped into a pile, and placed into buddles. The buddles were a series of stepped grating, over which another flow of water separated the finest grains of copper leftover. The remaining material, called bursom, was dumped outside in a heap along with attle and waste rock raised from the mine. ${ }^{102}$

\footnotetext{
${ }^{101}$ Robert E. Clarke, "Notes from the Copper Region," Harper's New Monthly Magazine March, April 1853: p.579.

${ }^{102}$ Ibid, p.580.
} 


\section{The First Dividend}

1848 saw continued success for the Cliff Mine as they managed to ship 830 tons of copper that year, an increase of over $100 \%$ from 1847 . Knowing increases like these would translate into large profits, the company decided to continue its program of improvements. It purchased outright from the U.S. Government the lands of Lease 5 for $\$ 2.50$ an acre, while letting Leases 4 and 6 lapse. All told, the property of the P\&BMC, valued at roughly $\$ 100,000$, now consisted of just over 4,350 acres, but only 50 acres of which were in use. ${ }^{103}$ The company erected 25 dwellings and a chapel for the community’s 300 Cornish, Irish, German, and French-Canadian immigrant inhabitants, and set aside 25 acres for cultivation, hay and root vegetables making up the lion's share of plantings. On the other 4,300 acres, favorable looking veins were known to exist, but as yet the work of the company confined itself to the base of the bluff, at "a single point, known to be valuable." 104

Improvements extended beyond the mine itself. Before 1850, all Cliff copper shipped from Eagle River eventually wound up in smelting works in Boston or Baltimore, as efforts to smelt on the Keweenaw (the incident at Ft. Wilkins being one example) had been met with difficulty. However, the smelting processes at both Boston and Baltimore were costly (freight to Boston being $\$ 15$ per ton, compared to $\$ 7.50$ for Pittsburgh) and ill suited to the massive boulders of copper the Cliff produced. ${ }^{105}$ Charles Hussey, one of the directors of the P\&BMC, decided to take control of the postproduction of the Cliff's copper, and went about experimenting with smelting techniques near the company's headquarters in Pittsburgh. ${ }^{106}$

In 1847, Hussey sent John Hays, long since removed as mine agent for the company, to Cornwall and Wales to learn of copper and tin smelting techniques there. Hays met with frustration, as the Old World competitors saw little advantage in giving up

\footnotetext{
${ }^{103}$ S.V.R. Trowbridge, "Trowbridge Report to the Michigan Secretary of State," Joint Documents of the Legislature (1850): p.57.

${ }^{104}$ Pittsburgh and Boston Mining Company. Report of the Committee of the Stockholders of the Pittsburgh and Boston Copper Harbor Mining Company. Pittsburgh: George Parkin \& Co., 1849. p.8-10.

${ }^{105}$ J.W. and Whitney, J.D. Foster, Report on the Geology and Topography of a Portion of the Lake Superior Land District. (Washington: House of Representatives, Executive Doc. 69. 31 st Congress. 1st Session., 1850), p.130.

${ }^{106}$ Donald Chaput, The Cliff: America's First Great Copper Mine (Kalamazoo: Sequoia Press, 1971), p.65.
} 
their knowledge to the American upstarts. Hays returned to Pittsburgh with little news, but over the next year Hussey's experiments with copper smelting would eventually transform the process and become the standard for the next 100 years.

The problems with furnaces of that time were twofold; they couldn't handle large masses of copper without the costly effort of chiseling them down into manageable pieces, and, the oxygen buildup in the molten copper required further processing after the initial blast. Hussey answered the first problem by giving the furnace a removable top that allowed for masses weighing up to 5 tons to be lowered into it. The top was then replaced and the entire contents heated indirectly by bituminous coal. This type of indirect heating, in a reverberatory style furnace, meant that slag rising to the top could be easily removed by skimming with iron hoes. To solve the second problem, large green hardwood logs were thrust into the molten copper, removing oxygen as it combined with carbon in the wood. ${ }^{107}$

Together, these two innovations in the smelting process brought Hussey another avenue of profit for himself and cost savings to the company. Cliff Mine copper no longer needed to travel beyond the reach of the P\&BMC, and both mass and stamp copper were then smelted in Pittsburgh. Hussey's reverberatory furnace worked wonderfully; the molten copper being, "ladled into little iron moulds, which are suspended by a hinge on an iron rod, running across a square cast iron vessel filled with water." Once cooled, the moulds were tipped over, dumping the copper ingots into the water to cool further. The finished product, consisting of 14-18 lb. ingots, were reported to be nearly $90 \%$ pure. $^{108}$

Enthusiasm abounded within the company. Even the onset of a seven-month long winter and the loss of many supplies after the sinking of the propeller, Goliath, in the fall of 1848 , couldn't deter the company's momentum. ${ }^{109}$ In the annual report to stockholders for 1849 , the directors of the P\&BMC announced earnings of \$202,071.97 and a cleared profit of $\$ 111,105.49$, almost equaling the company's entire initial capital stock. The director's could hardly contain

\footnotetext{
${ }^{107}$ Ibid; Thomas Egleston, "Copper Refining in the united States," Transactions of the American Institute of Mining Engineers; May 1880 to February 1881 1881: p.680.

${ }^{108}$ Lake Superior News \& Mining Journal 30 Sept. 1848.

109 Ibid.
} 
Table 1. Showing the dividends paid by the Pittsburgh and Boston Mining Company, 1859-1879. Semi-annual dividends have been combined by year.

\begin{tabular}{|c|c|c|c|}
\hline Year & $\begin{array}{l}\text { Balance Before } \\
\text { Dividend }\end{array}$ & $\begin{array}{l}\text { Dividend Amount } \\
\text { (Per Share) }\end{array}$ & Dividends Paid \\
\hline 1846 & Unknown & None Given & None Given \\
\hline 1847 & Unknown & None Given & None Given \\
\hline 1848 & $\$ 111,105.00$ & None Given & None Given \\
\hline 1849 & $\$ 148,355.00$ & $\$ 10.00$ & $\$ 59,920.00$ \\
\hline 1850 & $\$ 117,992.00$ & $\$ 14.00$ & $\$ 83,398.00$ \\
\hline 1851 & $\$ 103,034.00$ & $\$ 10.00$ & $\$ 59,085.00$ \\
\hline 1852 & $\$ 127,216.00$ & $\$ 10.00$ & $\$ 59,315.00$ \\
\hline 1853 & $\$ 116,949.00$ & $\$ 15.00$ & $\$ 90,000.00$ \\
\hline 1854 & Unknown & $\$ 18.00$ & $\$ 108,000.00$ \\
\hline 1855 & Unknown & $\$ 13.00$ & $\$ 77,920.00$ \\
\hline 1856 & Unknown & $\$ 30.00$ & $\$ 179,900.00$ \\
\hline 1857 & $\$ 296,897.00$ & $\$ 30.00$ & $\$ 180,000.00$ \\
\hline 1858 & $\$ 264,735.00$ & $\$ 15.00$ & $\$ 159,206.00$ \\
\hline 1859 & $\$ 122,050.00$ & $\$ 9.00$ & $\$ 177,052.00$ \\
\hline 1860 & $\$ 95,949.00$ & None Given & None Given \\
\hline 1861 & Unknown & $\$ 4.00$ & $\$ 79,004.00$ \\
\hline 1862 & $\$ 120,731.00$ & $\$ 4.00$ & $\$ 79,084.00$ \\
\hline 1863 & $\$ 438,768.00$ & $\$ 5.00$ & $\$ 100,000.00$ \\
\hline 1864 & $\$ 308,497.00$ & $\$ 8.00$ & $\$ 160,000.00$ \\
\hline 1865 & $\$ 188,073.00$ & $\$ 10.00$ & $\$ 200,000.00$ \\
\hline 1866 & $\$ 262,246.00$ & $\$ 3.00$ & $\$ 60,000.00$ \\
\hline 1867 & $\$ 191,010.00$ & $\$ 3.00$ & $\$ 60,000.00$ \\
\hline 1868 & $\$ 259,077.00$ & $\$ 3.00$ & $\$ 60,000.00$ \\
\hline 1869 & $\$ 198,507.00$ & None Given & None Given \\
\hline $1870-1878$ & $\mathrm{~N} / \mathrm{A}$ & None Given & None Given \\
\hline 1879 & $\$ 38,620.00$ & $\$ 1.93$ & $\$ 38,620.00$ \\
\hline Totals & N/A & 212.93 & $\$ 2,070,504.00$ \\
\hline
\end{tabular}

their optimism for the future stating, "after encountering and successfully overcoming a variety of discouraging vicissitudes, assumed a position, calculated to challenge the confidence of the most skeptical," and that, "a more favorable combination of circumstances could hardly have been desired." The directors declared a dividend of $\$ 10$ a share on May $21^{\text {st }}$, and paid out $\$ 60,000$ to the company's stockholders. This would be the very first dividend ever paid by a mining company in the district, and the first of many for Cliff over the next 20 years (Table 1). ${ }^{110}$

\footnotetext{
${ }^{110}$ Pittsburgh and Boston Mining Company. Report of the Committee of the Stockholders of the Pittsburgh and Boston Copper Harbor Mining Company. Pittsburgh: George Parkin \& Co., 1849. p.3-10.
} 


\section{The Keweenaw Takes Off}

Hoping to capitalize on the Cliff's success, other large-scale mining concerns soon dotted the Keweenaw and the rest of the copper country, yet even with the new competition, the Cliff dominated the copper mining industry. The majority of these new mines, the Albion, Star, Eagle Harbor, Northwestern, Dana, Arnold, and Madsion mines for example, failed to find their own versions of the Cliff Vein. A few however, managed to combine a property with a promising fissure or two with timely investment. The Phoenix, Copper Falls, Central, and Northwest (later the Delaware), all contemporaries of the Cliff, became successful fissure mines in their own right, and in some cases continued producing well after the Cliff's profitable period ended.

To the south in the Ontonagon District, the great Minesota Mine put up the first real challenge to the Cliff's superiority in the race to raise copper. Opened (by AngloAmericans-the native peoples of the Upper Peninsula knew about it long before) in 1847, the Minesota vein paid its first dividend within 5 years of opening. Known for immense specimens of mass copper (in one case an estimated 500 tons!), the Minesota encouraged mining in Ontonagon just as the Cliff did in the Keweenaw, and soon the National, Ridge, Norwich, and Adventure Mines sprang up along Superior's southern shore. ${ }^{111}$

At this time the copper mines of the region were connected to Lake Superior first and to each other second. Incoming supplies and outgoing copper product all came through a handful of ports: Copper Harbor, Eagle Harbor, and Eagle River in the Keweenaw, the town of Ontonagon in the south. Roads connecting the mines to the port communities were rough affairs, often muddy to the point of uselessness. Navigation on the lake was closed in winter, effectively cutting the mines of from the rest of the world for up to seven months a year. ${ }^{112}$ Railroads, integral to the development of the Portage Lake District in the coming decades, had yet to be utilized in the Keweenaw and Ontonagon Districts. In the case of Cliff, the mine had long passed its prime before rail could make an impact. ${ }^{13}$

\footnotetext{
${ }^{111}$ Charles E. Wright, Annual Report of the Commissioner of Mineral Statistics of the State of Michigan, for 1880 (Lansing: W.S. George \& Co., 1881), p.74-77.

${ }^{112}$ Larry Lankton, Cradle to the Grave: Life, Work, and Death at the Lake Superior Copper Mines. (New York: Oxford Univeristy Press, 1991), p.13.

${ }^{113}$ Ibid. p.54.
} 
During this time, some members of the P\&BMC looked to multiply their luck by getting involved with other companies. In each case, their luck seemed to stop with the Cliff. Thomas Howe and Charles Hussey were also directors of the unlucky Northwestern Mine, a failed venture located just a few hundred feet off the Central Vein, discovered by future Cliff superintendent John Slawson, and believed to be "one of the most valuable deposits of mineral...in Lake Superior." 114 Hussey also had a hand in the Adventure Mine, an appropriately named operation considering the unique nature of the mine's work, where the failure to find mineral "confined to a single vein" made it the first mine in the copper country to adopt the tribute system. ${ }^{115}$

\section{Transition to Steam Power}

Coming off of 1848's success, the Cliff Mine further increased production the next year, shipping over 1,000 tons of mineral to Pittsburgh where it yielded 660 tons of refined copper. Brought to market, the final product fetched $\$ 244,237.54$, helping the company clear a profit of $\$ 148,355.75$. Out of these profits, another two (semi-annual) dividends of $\$ 7.00$ were declared and paid out in the winter and summer of $1850 .{ }^{116}$ This still left over $\$ 60,000$ in the company's coffers, and much of it went towards updating the mine's primitive surface workings.

At this point, the two working shafts were each nearing 300 feet vertically and horse whims could no longer handle raising large amounts of material from those depths effectively. Drifts clogged with stamp work and waste rock, along with a drop in mass and barrel work production in 1850 , were evidence to the severity of the situation. ${ }^{117}$ The mine's expansion vertically made draining the mine by whim more difficult as well. Miners found that the vein's appearance grew south of the bluff below the $4^{\text {th }}$ level, taking the company by surprise as upper levels showed the southern portions of the vein

\footnotetext{
${ }^{114}$ Charles E. Wright, Annual Report of the Commissioner of Mineral Statistics of the State of Michigan, for 1880 (Lansing: W.S. George \& Co. , 1881), p.59.

${ }^{115}$ Ibid. p.99-100.

${ }^{116}$ Pittsburgh and Boston Mining Company. Report of the Committee of the Stockholders of the Pittsburgh and Boston Copper Harbor Mining Company. Pittsburgh: George Parkin \& Co., 1850. p.3-6.

117 J.D. Whitney, The Metallic Wealth of the United States: Described and Compared with that of Other Countries. (Philadelphia: Lippincott, Grambo \& Co., 1854), p.278.
} 
to be poor. ${ }^{118}$ Increases in stoping also put a strain on the water-powered stamp mill, as an increase in the number of stamp heads called for more efficient power. These challenges could all be met by steam power, and the mine's success now made it possible to afford the establishment of modern technological equipment at the site.

The company contracted Nicholas Vivian, a civil engineer from Cornwall living in Pittsburgh, to construct a steam engine for the purposes of raising copper, water, and rock. Installed in late September of that year, the massive engine, along with an additional smaller pumping engine, managed to handle all the work of both shafts at once. To aid in the running of the new machinery, a small model of the shafts and hoist equipment provided a working diagram that directed the speeding up and slowing down of the engine. ${ }^{119}$

The winding and pumping engines were housed in a newly constructed engine house built of waste rock located just downhill from the whims and shafts. The building also housed one or two boilers to provide steam for the new machinery. Vivian's large "walking-beam" engine was of the vertical beam type common to Cornwall, but the first of its kind to be installed in the Keweenaw. ${ }^{120}$ This Cornish style engine consisted of a sea-saw like appendage, or beam, that extended outwards from the engine house and moved up and down following the rise and fall of a piston inside the engine house. Connected via rods to winding drums, or pumps, the vertical beam engine could raise and lower material from the mine or have its vertical action turned perpendicular via rotation in order to drive whims, capstans, and pulleys at the surface. In this case, the engine connected to two whims in order to handle the raising and lowering of kibbles in two shafts, both of which were located to the left of the beam.

In all, the investment in the two steam engines amounted to roughly $\$ 20,000$, a third of the company's capital. The investment quickly justified itself and the mine soon ordered another engine from Vivian for a new stamp mill to be built that upcoming summer and fall. Soaring to 5 stories in height, this new mill built mainly of stone, had

\footnotetext{
${ }^{118}$ Ibid, p.4-5.

${ }^{119}$ Lake Superior Journal 13 Nov. 1850.

${ }^{120}$ Ibid.
} 
Table 2. Steam engines at the Cliff. From, Lake Superior Miner. 29 Jan. 1857.

\begin{tabular}{|l|c|c|c|l|r|}
\hline \multicolumn{1}{|c|}{ Description } & $\begin{array}{c}\text { Diameter of } \\
\text { Cylinder }\end{array}$ & Stroke & $\begin{array}{c}\text { Horse } \\
\text { Power }\end{array}$ & \multicolumn{1}{|c|}{$\begin{array}{c}\text { Probable } \\
\text { Purpose }\end{array}$} & $\begin{array}{c}\text { Probable } \\
\text { Cost }\end{array}$ \\
\hline Vertical High Pressure & $24 \mathrm{inch}$ & $8 \mathrm{ft}$. & 30 & Hoisting & $\$ 15,000$ \\
\hline Horizontal High Press* & $24 \mathrm{inch}$ & $6 \mathrm{ft}$. & 80 & Stamping/Pumping & $\$ 8,000$ \\
\hline Horizontal High Press. & $12 \mathrm{inch}$ & $4 \mathrm{ft}$. & 21 & Pumping & $\$ 6,000$ \\
\hline Horizontal High Press. & $17 \mathrm{inch}$ & $4 \mathrm{ft}$. & 42 & Hoisting & $\$ 8,000$ \\
\hline Horizontal High Press. & $10 \mathrm{inch}$ & $2 \mathrm{ft}$. & 31 & Sawing & $\$ 2,000$ \\
\hline Horizontal High Press. & 6 inch & $1.5 \mathrm{ft}$. & 5.5 & Blowing & $\$ 300$ \\
\hline
\end{tabular}

* May be a misprint. According to the Lake Superior Journal 5 June 1852, it was a low pressure engine.

walls "thick and strong enough for a fortress." ${ }^{\text {"121 }}$ Vivian's 80 horsepower engine had a 24 -inch cylinder and 6-foot stroke, and initially drove 36 stamps, handled pumping from the mine and eventually the washing tables as well. ${ }^{122}$ The reliance on steam would increase over the next decade. By 1857 there were six engines, both vertical and horizontal in orientation, on the property (Table 2). ${ }^{123}$

\section{Profits Over Planning}

The introduction of steam power to the mine brought with it an increase in productive potential, but it also blinded the $\mathrm{P} \& \mathrm{BMC}$ to possible future financial problems. At the cost of a lower working capital, the company issued dividends every year (sometimes twice a year) to stockholders from 1849-1853 for a total of $\$ 59.00$ per share. Although that might make for happy investors, a healthy working capital is required to maintain a profitable business model. The mine's copper production accounted for nearly $2 / 3$ of all the copper produced in the Great Lakes at that time, and many believed it was only the beginning (Table 3). The Journal of Copper Mining Operations stated that, "These results, great as they are, will probably be looked upon,

${ }^{121}$ Ibid.

$122 \frac{1}{29}$ Oct., and 1 Dec. 1851.

${ }^{123}$ J.D. Whitney, The Metallic Wealth of the United States: Described and Compared with that of Other Countries. (Philadelphia: Lippincott, Grambo \& Co., 1854), p.278. And Lake Superior Journal 5 June 1852. 
Table 3. The below table from DeBow's Review shows the operating copper mines in the Keweenaw, Portage Lake, and Ontonagon Districts as of Feb. 1853. Cliff, the Minesota (misspelled with two $n$ 's here), and North American mines were the only users of steam at this time. Of note is the complete dominance of the Cliff in terms of annual production, making up $2 / 3$ of the $1,525+$ tons produced that year. ${ }^{124}$

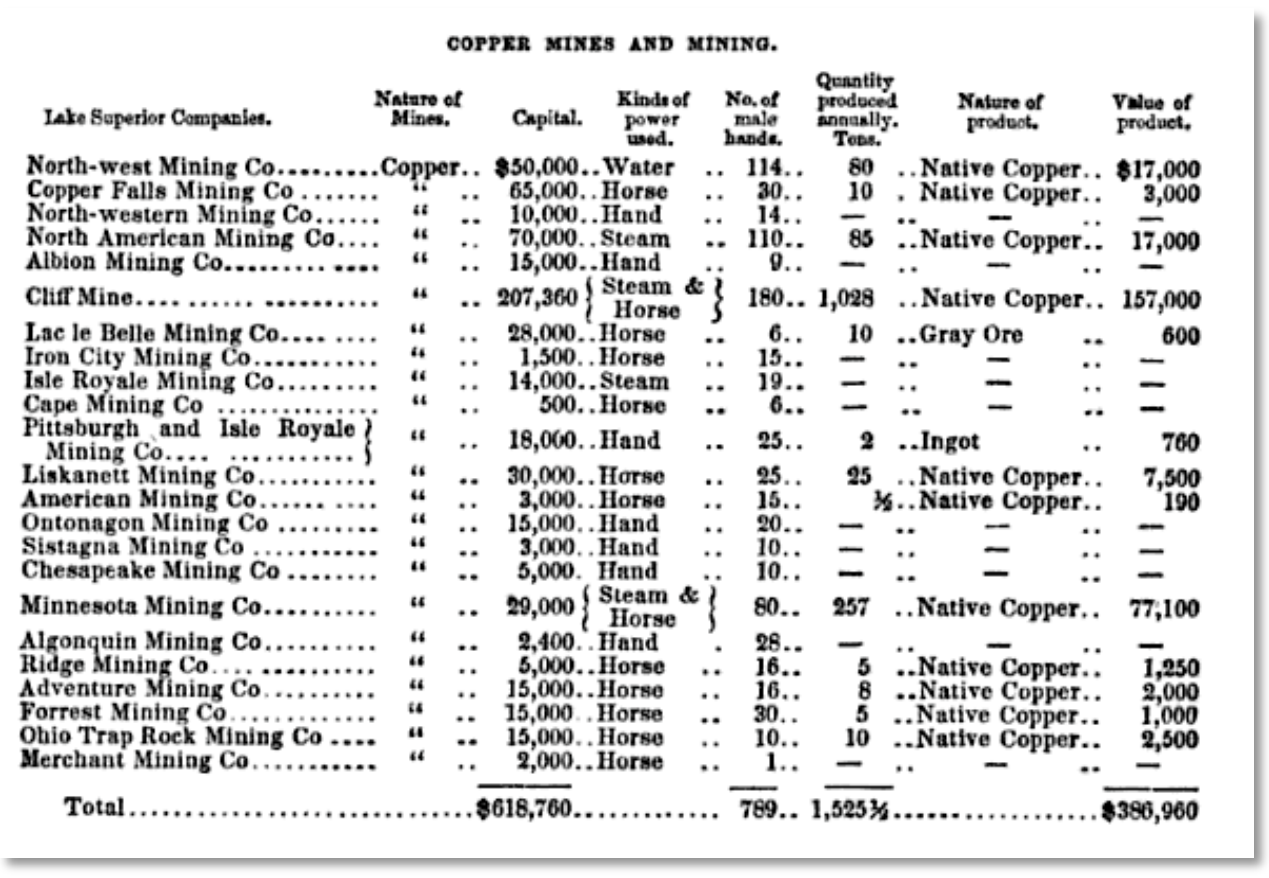

some years hence, as a small affair when compared with the success of companies now in their infancy.",125

This viewpoint, also held by the soon to be resigning mine Superintendant Capt. William Jennings, would put the Cliff in a mindset of profit over planning. However, 1852 saw the first in a series of minor incidents, disasters, and purchases that on their own were of little consequence to a mine as profitable as the Cliff, but together forced the P\&BMC to assess the state of their workings.

In October of that year, a fire set by a disgruntled employee destroyed the old stamp mill entirely and damaged the new 5 story mill located nearby to the amount of $\$ 5,000$, though luckily the new engine and machinery were spared. Also in 1852, a flood

\footnotetext{
${ }^{124}$ J.D.B. De Bow, “Copper Mines: Commerce of Lakes Erie, Huron, Michigan, etc. ," De Bow's Review: Devoted to the Restoration of the Southern States and the Development of Wealth and Resources of the Country. 1853: 493.

125 "Journal of Copper Mining Operations," Mining Magazine: Devoted to Mines, Mining Operations, Metallurgy, etc. 1854: p.618.
} 
on the Ohio River destroyed two furnaces at the smelter in Pittsburgh, causing a delay in finished product. Yet even as a finished product, Cliff copper couldn't find a market outside the East Coast, as production actually depressed copper prices nationwide from 21 to 18 cents per pound. ${ }^{126}$ Locally, supply costs increased and average freight rates rose $\$ 0.35 .{ }^{127}$ Further, in a rush to expand the property of the P\&BMC in the hopes of finding another vein like the Cliff, 5,300 acres were purchased to the south and east for $\$ 11,616.52$. Together, tackling these problems and expenditures without decreasing dividends (they issued another $\$ 16.00$ per share in 1854) meant a reduction of working capital to under $\$ 9,000$ by the start of $1854 .^{128}$

The underground workings of the mine at this point reached nearly 500 feet below the surface, and the vein held steady moving both north and south from the No. 1 and No. 2 Shaft's area near the base of the bluff. For the time being, it appeared as though the vein would hold vertically as well, and that the location of the shafts were perfectly placed to conduct the work. In fact, they were situated too close to one another, and may have attributed to a fever epidemic that overtook the mine in the winter of 1852-53 due to a "want of circulation."129 The two shafts were described as "miserable affairs" of "irregular and ill construction," choked with waste rock and debris due to a lack of openings. Hoisting kibbles became difficult and dangerous as the chains often broke on the crooked angles of the shaft, sending the large iron buckets down hundreds of feet. ${ }^{130}$ The mine needed to take a new direction, both underground and organizationally.

\section{Moving North}

By the mid 1850's, fissure mines working mass copper dotted the Keweenaw and Ontonagon mining districts. The Copper Falls, Central, Northwestern, and new mines

\footnotetext{
${ }^{126}$ Pittsburgh and Boston Mining Company. Report of the Committee of the Stockholders of the Pittsburgh and Boston Copper Harbor Mining Company. Boston: S.N. Dickinson and Co., 1853. pp.9-10.

127 "Journal of Copper Mining Operations.," Mining Magazine: Devoted to Mines, Mining Operations, Metallurgy, etc. 1853: p.426.

${ }^{128}$ Pittsburgh and Boston Mining Company. Report of the Committee of the Stockholders of the Pittsburgh and Boston Copper Harbor Mining Company. Boston: S.N. Dickinson and Co., 1854. pp.6-11.

${ }^{129}$ Lake Superior Journal, 9 July 1853.

${ }_{130}$ Lake Superior Miner, 10 May 1856; E.R. Penberthy, "Letter from E.R. Penberthy to J.A. Doelle (Sec. and Treas.. of Keweenaw Historical Society) Dates Feb. 1st, 1913," (Keweenaw Historical Society, 1913) p.2.
} 
begun after the Cliff struck it rich began to challenge the Cliff's reputation as "miserly and mean" with people "crowded into log hovels."

In response to growing complaints and competition from the Portage Lake district, new mine superintendent John Slawson began a number of improvements on the surface and underground in the hopes of reversing negative views towards the mine and its workings. Slawson first saw to the community and surface of the mine. New buildings such as a 50x100 foot washhouse, fire proof storehouse, powder house, stone smith shop, mineral house, saw mill, carpenter shop, and changing house were all built to meet the mine's needs. The road to Eagle River, a shambles of steep mud in either direction, was planked, halving freight costs for the teamsters hauling copper to the dock. The evergrowing community of Clifton made room for their first church and ten new dwelling houses, each with its own garden plot $^{132}$

As for the underground workings, Slawson tackled the mine's ventilation issues first, sinking a third shaft (named the No. 3 Shaft) at the top of the bluff in the winter of 1853-54. The shaft sat 200 plus feet horizontally north of the No.'s 1 and 2 Shafts and 138 vertical feet above them, with nothing but greenstone (crystalline trap) to dig through. Along with ventilation, the shaft allowed for another extraction point for waste rock that clogged the drifts of the mine. After being raised up to the top of the shaft, waste rock was dumped back down the face of the bluff, the most convenient place for rock to be disposed of. ${ }^{133}$

Following the sinking of the No. 3, Slawson called for the sinking of a fourth shaft, located 900 to the north of the No. 3, in order to keep up with a vein "making north." A massive undertaking, the Howe (named for Thomas Howe) Shaft would take 34 years to complete at a cost of $\$ 17,500$. In a challenging feat of engineering, the meeting of two separate digging crews, with one sinking from above with the other rising from below created the shaft. ${ }^{134}$ The No. 3 and Howe shafts signaled a return of work to the

\footnotetext{
${ }^{131}$ Lake Superior Journal 13 Oct. 1855.

132 Lake Superior Miner 10 May 1856; Lake Superior Journal 13 Sept.1856.

133 J.D. Whitney, The Metallic Wealth of the United States: Described and Compared with that of Other Countries. (Philadelphia: Lippincott, Grambo \& Co., 1854), p.277.

${ }^{134}$ Pittsburgh and Boston Mining Company. Report of the Committee of the Stockholders of the Pittsburgh and Boston Copper Harbor Mining Company. Boston: S.N. Dickinson and Co., 1854. pp.13-14.
} 
top of the bluff, where the vein's discovery happened almost a decade earlier. The company at last had to face the imposing landscape of the Cliff and adapt to its hold on the vein. For the rest of the Cliff's run, the bluff would become the dividing line between two distinct, yet linked (by 1859 at least), surface plants with their own workers, industrial buildings, and support structures.

At the base of the bluff, the sorry state of the No.'s 1 and 2 shafts needed to be addressed as well. Another shaft, named the Avery Shaft in honor of the recently deceased company president, Dr. Charles Avery, was begun sometime late in 1857 and set just east of the original shafts. Unlike the No.'s 1 and 2, the Avery's location just off the vein meant that sinking didn't have to follow the course of the lode at all, and could be dug through solid rock. This allowed for keeping the $12 \times 7$ foot shaft straight or "squared down" its entire length, and meant larger kibbles and masses of copper could be raised without fear of breaking chains and endangering the miners. The size and vertical consistency of the shaft lead the directors of the P\&BMC to declare, "that the working capacity of [the Avery] will be nearly, if not quite, equal to that of all the shafts hitherto in use." $" 135$

\section{Modernization Conquers the Bluff}

Slawson's "determination to redeem the reputation of the Company" meant adopting new technologies, with the stamp mill chosen as the first guinea pig. ${ }^{136}$ During much of 1857,24 of the 36 Cornish style gravity stamps in place weren't used due to their condition, dropping copper shipments $31 \%$ from the previous year. In order to make up the loss, three new stamps were purchased from Samuel Hodge of Detroit and installed in September of that year. These new stamps (Fig. 2-9) differed from the 36 stamps already in use in the way that they lifted and dropped the stamp shoe and iron stem. Instead of being lifted via a single camshaft, these crushers rose and fell due to a pair of grooved rollers that grasped the stem and raised it on one revolution, then dropped it on the following revolution. When working correctly, the rollers allowed for a

\footnotetext{
${ }^{135}$ Report of the President and Directors of the Pittsburgh and Boston Mining Company, Annual Report 1858, p.19; Annual Report 1859, pps.9-10.

${ }^{136}$ Lake Superior Miner 2 May 1857.
} 


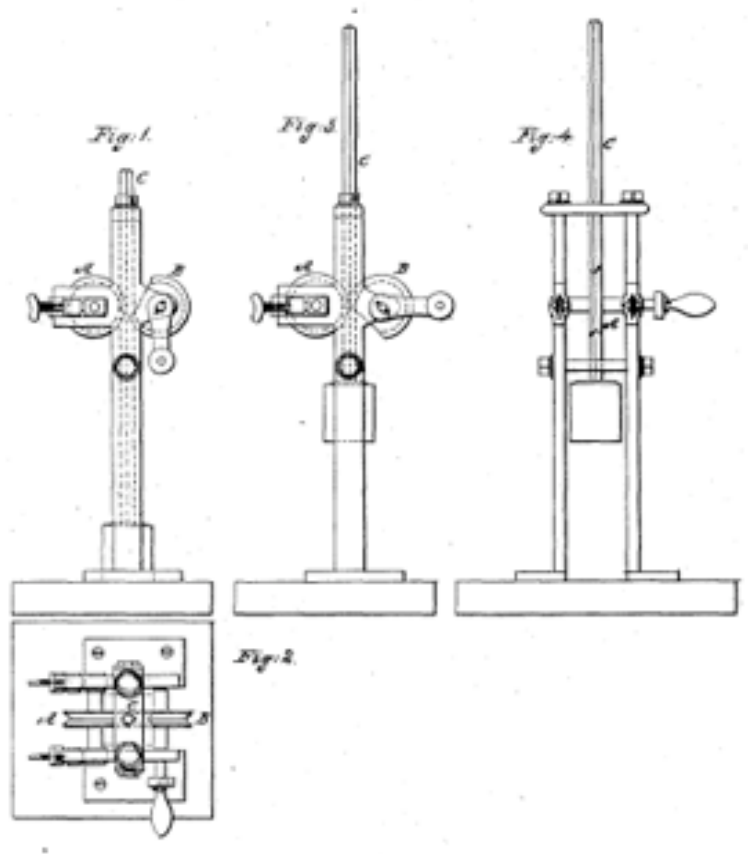

Fig. 2-9. Samuel Hodge's ore stamp. The two grooved wheels worked together to lift the stem and then drop it on to passing ore. (From US Patent 17374. 26 May 1857)

uniform drop of $3 \frac{1}{2}$ feet, which was an improvement over the 10 inch drop of the gravity stamps. ${ }^{137}$

Within a year, the new stamps "erected upon the original plan" were found to be "defective in the mode adopted for lifting them" and were out of use for a time, dropping the productivity of the mill over the winter of 1858-59. Hodge repaired the equipment and "the improved stamps appear[ed] to be a perfect success." They worked so well in

\footnotetext{
${ }^{137}$ Pittsburgh and Boston Mining Company. Report of the Committee of the Stockholders of the Pittsburgh and Boston Copper Harbor Mining Company. Boston: S.N. Dickinson and Co., 1858. p.7-8; Lake Superior Miner 19 Sept. 1857.
} 
fact that eight new stamp heads were ordered and erected by the end of 1859 , and Slawson hoped they would handle 150 tons per 24 hours, an increase of about 100 tons a day. Along with the new heads, a rock crusher was also procured that would decrease the workforce dedicated to rock breaking by three quarters. The Cornish stamps kept running to complement the Hodge equipment and together, and the improvements to the mill had an immediate effect. The cost for preparing, stamping, and washing ore dropped $\$ 0.12$ per pound to $\$ 1.31$, while at the same time increasing the tonnage of ore shipped $28 \%$ from the previous year.

Slawson's prediction of increases in workable rock came true soon after the equipments addition to the mill. From 1859-1860, the tonnage of raised stampings worked at the mill rose $37 \%$, from 13,600 to 18,700 tons. For the next decade, stamp work would account for $31-41 \%$ of the shipped copper from Cliff, an increase of $10-20 \%$ from the previous 15 years (Table 4).

Other ideas also came up during this period of renewed investment and modernization, some were followed, some ignored. Towards the end of the decade, discussion to put in an inclined railway shaft to help alleviate removal of waste rock took place annually. The inclined shaft was to lead from the base of the bluff and follow the dip of the slide to the Howe (No. 4) Shaft, but in the end costs dictated that investing in the Avery and Howe would be sufficient and the project never got beyond the planning stages. ${ }^{138}$ Two more engines were purchased for $\$ 30,000$, with one ending up at the Avery to handle pumping while the second, a portable, handled hoisting at the Howe.

The issue of growing waste rock piles lead to another decision that coincided with the completion of the Avery and Howe Shafts. While the inclined shaft never caught on as a viable idea, an inclined tramway, leading from the top of the bluff down to the stamp mill, did. Completed in the summer of 1859 , the tramway connected the No. 3 Shaft to the stamp mill lying at the base of the bluff. A stockpile of ore and stamp rock that had

\footnotetext{
${ }^{138}$ Pittsburgh and Boston Mining Company. Report of the Committee of the Stockholders of the Pittsburgh and Boston Copper Harbor Mining Company. Boston: S.N. Dickinson and Co., 1858. p.10-11.
} 
Table 4. Shipped copper from 1846-1870, divided by category. Of note is the steady increase in reliance on stamp work by the late 1850 's as stamp machinery improved.

\begin{tabular}{|c|c|c|c|c|c|c|}
\hline Year & $\begin{array}{l}\text { Copper } \\
\text { Masses } \\
\text { (in lbs.) } \\
\end{array}$ & $\begin{array}{c}\text { Barrel } \\
\text { Work } \\
\text { (in lbs.) } \\
\end{array}$ & $\begin{array}{c}\text { \% of } \\
\text { Shipments }\end{array}$ & $\begin{array}{c}\text { After } \\
\text { Washing } \\
\text { (in lbs.) }\end{array}$ & $\begin{array}{c}\text { \% of } \\
\text { Shipments }\end{array}$ & $\begin{array}{c}\text { Total } \\
\text { Shipped } \\
\text { (in tons) } \\
\end{array}$ \\
\hline 1846 & Unknown & Unknown & Unknown & Unknown & Unknown & $\mathrm{N} / \mathrm{A}$ \\
\hline 1847 & Unknown & Unknown & Unknown & Unknown & Unknown & 365 \\
\hline 1848 & $1,209,852$ & 486,487 & $84 \%$ & ap. 310,351 & $16 \%$ & 1003 \\
\hline 1849 & $1,077,884$ & 566,314 & $80 \%$ & ap. 335,070 & $20 \%$ & 989 \\
\hline 1850 & 710,046 & 482,322 & $79 \%$ & ap. 307,250 & $21 \%$ & 749 \\
\hline 1851 & 836,409 & 515,462 & $81 \%$ & 312,954 & $19 \%$ & 832 \\
\hline 1852 & 877,789 & 705,421 & $81 \%$ & 378,569 & $19 \%$ & 980 \\
\hline 1853 & 632,496 & 535,799 & $54 \%$ & $1,094,887$ & $46 \%$ & 1126 \\
\hline 1854 & Unknown & Unknown & Unknown & Unknown & Unknown & 1166 \\
\hline 1855 & Unknown & Unknown & Unknown & Unknown & Unknown & 1498 \\
\hline 1856 & Unknown & Unknown & Unknown & Unknown & Unknown & 1645 \\
\hline 1857 & $1,958,181$ & 613,731 & $76 \%$ & 791,645 & $23 \%$ & 1681 \\
\hline 1858 & $1,633,235$ & 637,886 & $71 \%$ & 911,964 & $29 \%$ & 1591 \\
\hline 1859 & 968,262 & 424,627 & $63 \%$ & 806,733 & $37 \%$ & 1100 \\
\hline 1860 & $1,339,329$ & 602,808 & $69 \%$ & 863,305 & $31 \%$ & 1402 \\
\hline 1861 & $1,564,153$ & 541,667 & $68 \%$ & 997,821 & $32 \%$ & 1552 \\
\hline 1862 & $1,295,700$ & 593,569 & $59 \%$ & $1,273,238$ & $41 \%$ & 1581 \\
\hline 1863 & $1,499,335$ & 562,133 & $69 \%$ & 949,071 & $31 \%$ & 1505 \\
\hline 1864 & Unknown & Unknown & Unknown & Unknown & Unknown & 1058 \\
\hline 1865 & 993,195 & 407,898 & $62 \%$ & 854,884 & $38 \%$ & 1128 \\
\hline 1866 & $1,041,200$ & 495,503 & $61 \%$ & 969,416 & $39 \%$ & 1253 \\
\hline 1867 & 617,190 & 341,388 & $56 \%$ & 734,678 & $44 \%$ & 846 \\
\hline 1868 & 915,780 & 291,972 & $65 \%$ & 667,298 & $35 \%$ & 937 \\
\hline 1869 & 445,015 & 198,213 & $55 \%$ & 536,839 & $45 \%$ & 590 \\
\hline 1870 & Unknown & Unknown & Unknown & Unknown & Unknown & 363 \\
\hline
\end{tabular}

been sitting at the top of the bluff for years could now be crushed and separated. ${ }^{139}$ It was also decided that the Avery Shaft would handle the raising of large masses of copper, as well as pumping from the mine, since getting the larger masses back down to the main mineral yard would be too difficult. The No.'s 1 and 2, Shafts were shut down, making the No. 3 and Howe Shafts the primary site for the raising of ore and waste rock (Fig. 210).

To make this new configuration of the surface systems work, getting ore and rock up from the now 110 fathom level depths of the Howe Shaft required two more innovations. The first, a pair of iron skips capable of hauling 2.5 tons apiece replaced the

\footnotetext{
${ }^{139}$ Pittsburgh and Boston Mining Company. Report of the Committee of the Stockholders of the Pittsburgh and Boston Copper Harbor Mining Company. Boston: S.N. Dickinson and Co., 1859. p.7.
} 


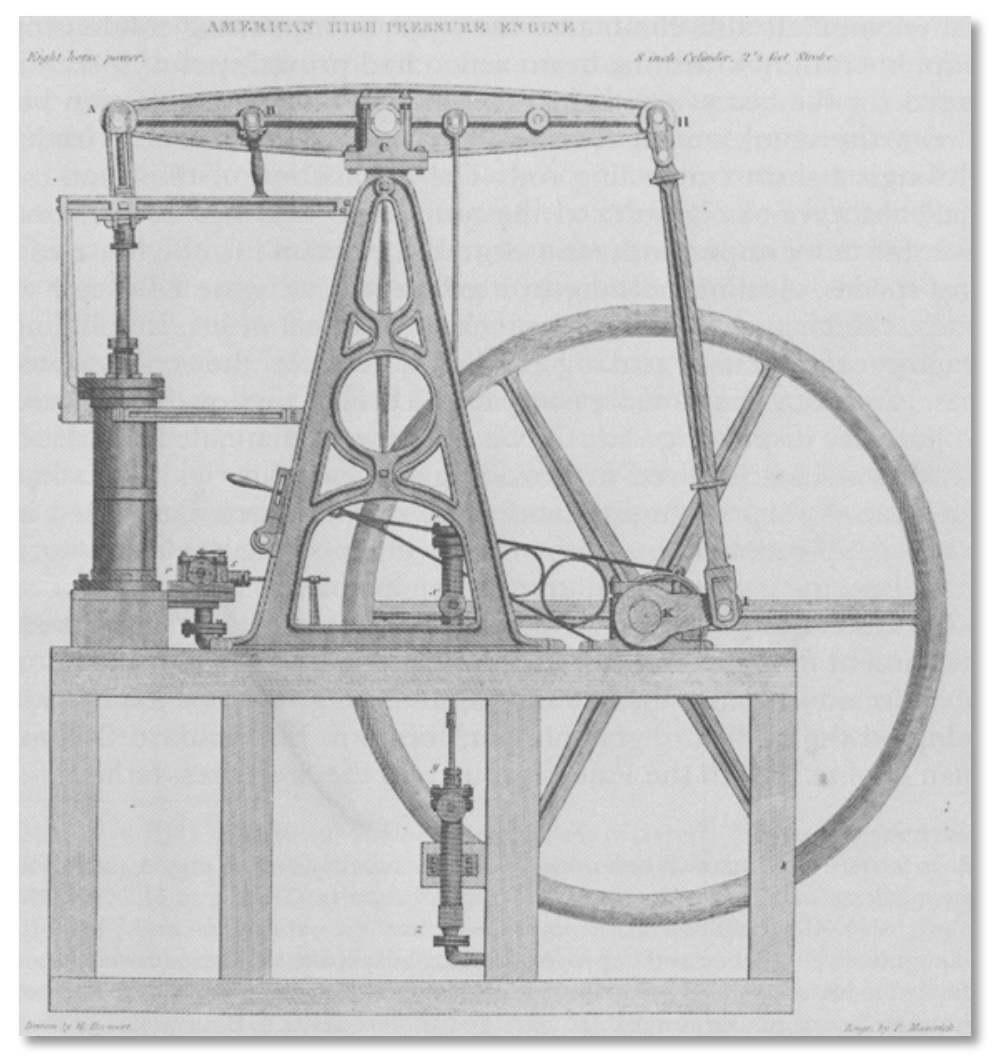

Fig. 2-10. An "American High Pressure Engine" from L.C. Hunter, A History of Industrial Power in the United States, 1780-1930. Vol II: Steam Power. (Charlotteville: Hagley Museum and Library, 1985) III vols., p.153. A vertical beam rotative engine like the one abovewas installed at the Howe Shaft. The large beam's see-saw motion drove the rotation of the fly-wheel. Attached to a crankshaft, this rotative power could be transmitted to a winding drum, its likely use at the Howe Shaft.

kibbles, took place in 1859. The skips acted much the same as the kibbles (one goes up while the other down) and sat parallel to a track that they rode down via wheels. The skips were capable of rising and lowering with full loads 10 times an hour, an incredible increase in efficiency over the kibbles, which could only handle a fraction of the load as that of a skip. ${ }^{140}$

The second innovation, a 1,000 foot long covered tramway, connected the Howe to the stamp mill below. At first, all rock at the top of the bluff went down an inclined tram to the base of the bluff. This was soon deemed inefficient, and it was decided that gravity should be made to do the work. Rock was simply dumped out of a tram car down

\footnotetext{
${ }^{140}$ Pittsburgh and Boston Mining Company. Report of the Committee of the Stockholders of the Pittsburgh and Boston Copper Harbor Mining Company. Boston: S.N. Dickinson and Co., 1860. p.8.
} 
a "rock chute" built at a 37-degree incline on top of the waste rockslide that draped the bluff as a result of the No. 3 Shaft's construction. The rock fell into bins from which it was sorted and loaded onto cars to be trammed over to the mill. ${ }^{141}$

The north-south spread of the workings was addressed in other ways as well. In order to minimize risk to the company for example, other possible mining operations on and around the property were kept separate, either in the form of new companies or as tribute work. In 1858, new veins uncovered to the north of the Cliff (yet still on the P\&BMC property) were explored under the direction of Sam W. Hill, and under his advisement a new company consisting of 1000 acres was carved out of these lands. Originally called the Swamscott Mining Company, the North Cliff Mining Company's board of directors would consist of many of the same directors as the P\&BMC and include Slawson himself (Fig. 2-11). Their decision to create a new company that might one day connect with the Howe Shaft, took the risk off the P\&BMC's stockholders, yet still allowed for possible profits in the future. Unfortunately, the mine never amounted to much, and operated on and off for a handful of years before running out of working capital and producing little copper. ${ }^{142}$ The plan to protect the Cliff from this new venture succeeded however, as the venture's failure only impacted the stockholders of the North Cliff Mining Company.

To the south, the North American Mining Company had been operating under the radar for over a decade, working the same vein as the Cliff, only on the other side of the west branch of the Eagle River. Never a consistent producer, the North American finally succumbed to the weight of unmet expectations after running out of working capital just as they hit a break in the vein and needed the capital most. In 1859, they sold their entire property (including buildings and machinery) to the $\mathrm{P} \& \mathrm{BMC}$ for $\$ 100,100$ (Fig. 2-11).

The P\&BMC knew the vein ran the entire length of the North American property, and banked on finding more productive lodes as they explored south. ${ }^{143}$ Early on, the company decided to work the "South Cliff" on tribute, taking $1 / 8$ of all profits earned in

\footnotetext{
${ }^{141}$ Mining Gazette 21 Feb. 1863.

142 North Cliff Mining Company. Report of the President and Directors of the North Cliff Mining Company. Pittsburgh: W.S. Haven, 1864. pp.4-17.

${ }^{143}$ Pittsburgh and Boston Mining Company. Report of the Committee of the Stockholders of the Pittsburgh and Boston Copper Harbor Mining Company. Boston: S.N. Dickinson and Co., 1860. p.13-14.
} 


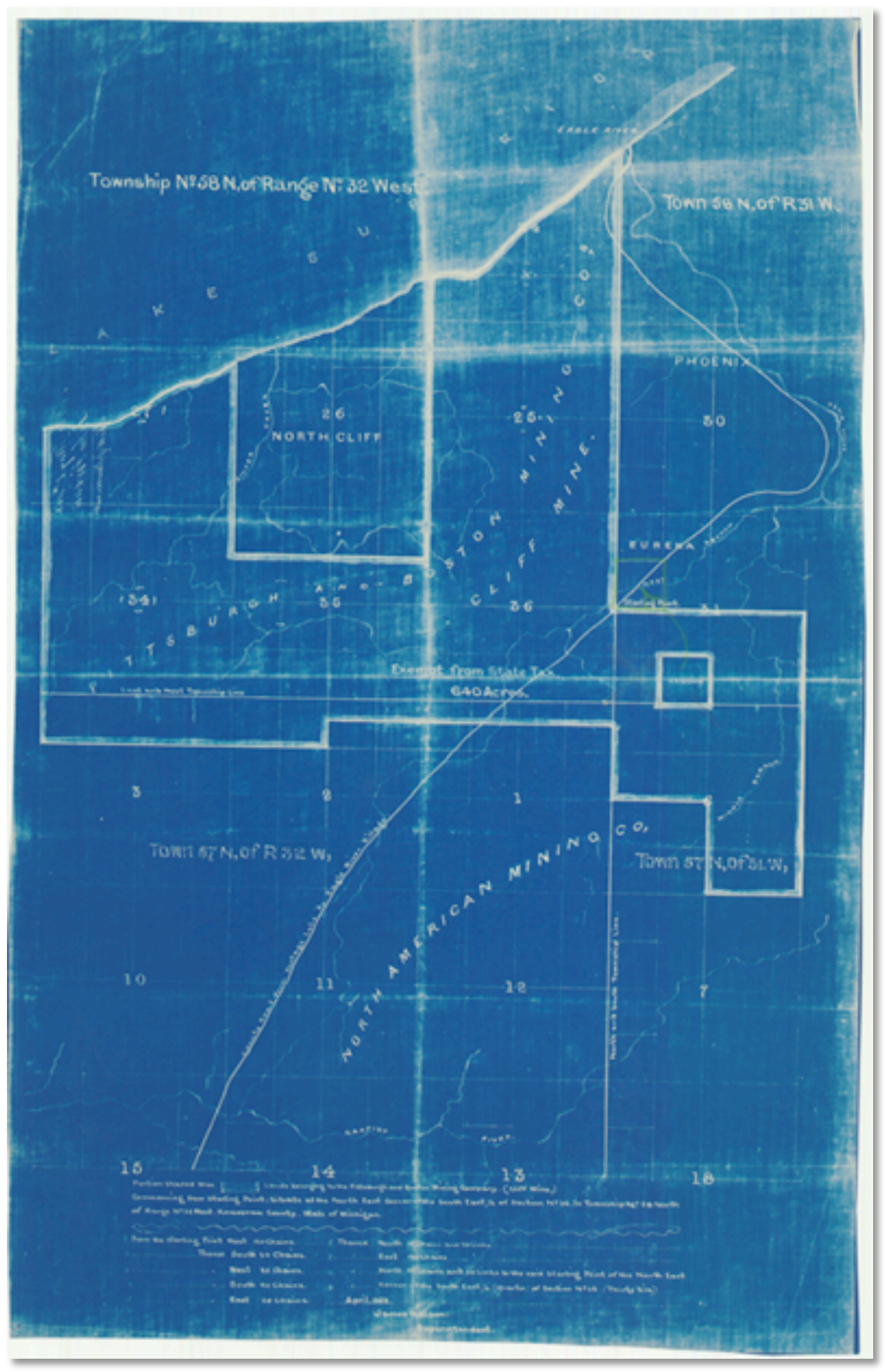

Fig. 2-11. Lands belonging to the Pittsburgh and Boston Mining Company (Cliff Mine), April 1862. The North Cliff Mining Company's lands are surrounded by the P\&BMC, while the North American Mining Company's lands occupy the area immediately below (to the south). Note the road leading to Eagle River where the Cliff Mine's docks were. (Map-29B-20A-1862, C\&H Map Collection. Michigan Tech Archives and Copper Country Historical Collections) 
the first couple years. Yet by the mid 1860's, the former North American property became the site of exploration more than profitable mining, and is rarely mentioned in the company's annual reports. ${ }^{144}$

During John Slawson's tenure as superintendent, the Cliff Mine grew to its largest physical and productive extent. The community contained three churches and 1500 residents, enough to justify the creation of a new school district and schoolhouse to go along with it. ${ }^{145}$ Within the industrial core, the property held three engine/hoist complexes, one for each working shaft, spread out over 1300 horizontal and 180 vertical feet respectively. In support many stone buildings, including two mineral houses, machine, blacksmith, and carpentry shops, and one of largest stamp mills on the Keweenaw also populated the surface of the mine. Tramways and rock chutes connected the top and bottom of the bluff and steam completely replaced horse and manpower in nearly every facet of work outside the actual drilling and blasting of rock. With the landscape seemingly conquered, the Cliff found itself with a new foe to confront.

\section{The Cliff Under Watson and Rawlings}

The 1860's were a period of transition for the Copper Country. The Keweenaw (and Cliff) no longer held claim to being the principal mover in the industry. For the first time since 1848, the dividend payments were withheld after the mine's production dropped by almost a third due to a decrease in the presence of mass copper. ${ }^{146}$ At the same time to the south, in the Portage Lake District, mines working amygdaloid and conglomerate deposits equaled the Keweenaw in terms of production. The Quincy Mine, begun in the mid-1850's had yet to earn its moniker, "Old Reliable," but by 1862, it was already outperforming the Cliff. For instance, in 1864 Quincy shipped 3,100,000 pounds to the Cliff's 2,100,000, earning the upstart mine more than double its older competitor.

\footnotetext{
${ }^{144}$ Pittsburgh and Boston Mining Company. Report of the Committee of the Stockholders of the Pittsburgh and Boston Copper Harbor Mining Company. Boston: S.N. Dickinson and Co., 1861. p.10.

${ }^{145}$ Pittsburgh and Boston Mining Company. Report of the Committee of the Stockholders of the Pittsburgh and Boston Copper Harbor Mining Company. Boston: S.N. Dickinson and Co., 1860. p.24 and 1861, p.16.

${ }^{146}$ Pittsburgh and Boston Mining Company. Report of the Committee of the Stockholders of the Pittsburgh and Boston Copper Harbor Mining Company. Boston: S.N. Dickinson and Co., 1860. pp.6-7.
} 
To add insult to injury, Quincy's product yielded nearly $20 \%$ higher purity, and mass copper wasn't even their primary target. ${ }^{147}$

The advantages the Portage Lake mines had over the Cliff and the Keweenaw were many. For one, they were younger and therefore shallower than the Cliff. At Quincy, miners didn't have to climb down 700 feet of ladders just to get to work. Second, they were located on Portage Lake, a large, deep-channel waterway that provided all the water necessary to run effective stamp mill operations. Further, other industries such as foundry and machine works found the location attractive, giving the mines in the area a leg up on new technology and timely repairs. When combined with large, productive ore bodies, it is no wonder the Portage Lake mines soon overtook those of the Keweenaw.

New competition and the Civil War also put on a drain on the workforce at the Cliff. Portage Lake, California, Pike's Peak, and even South America were luring miners away from the Keweenaw. ${ }^{148}$ Over the course of four years (1860-1863), the number of men employed underground and at the surface dropped $40 \%$, from 516 to 369. Labor shortages like these required new ways of doing business, and the Cliff soon attempted to remedy the situation by focusing on new sources of copper and systematizing work to cut costs. The men chosen to oversee the Cliff Mine during this period were new superintendent, James Watson and his "engineer in chief," Joseph Rawlings. ${ }^{149}$

Soon after taking the superintendent's position, Watson convened a meeting of all the mine officers to go over work and discuss a growing problem of waste at the works. For years, mine captains placed orders for equipment and materials without defining specific needs. The men who handled the books (the clerks and accountants) were men not accustomed to mine work, and filled orders without question. Rawlings realized that many of these orders were well over the requirements for the given job, and that mine captains often failed to report or return unused materials. He first suggested conducting a

\footnotetext{
${ }^{147}$ Charles E. Wright, Annual Report of the Commissioner of Mineral Statistics of the State of Michigan, for 1880 (Lansing: W.S. George \& Co., 1881), p.124-125.

${ }^{148}$ Philip P. Mason, ed., Copper Country Journal: The Diary of Schoolmaster Henry Hobar, 1863-1864. (Detroit: Wayne State Press, 1991), p.157.

${ }^{149}$ Pittsburgh and Boston Mining Company. Report of the Committee of the Stockholders of the Pittsburgh and Boston Copper Harbor Mining Company. Boston: S.N. Dickinson and Co., 1860-1864; Joseph Rawlings, "Recollections of a Long Life," Roy W. Drier, Copper Country Tales Vol. I (Calumet: Roy Drier, Publ., 1967), p.109.
} 
thorough survey of the mine's warehouse. After knowing what materials were on hand, one could instruct the smiths at the surface to fill out slates listing who they worked for (filling out specific orders by mining captains) and what materials they used. Watson liked Rawlings' idea, and quickly expanded the practice to the mine captains underground as well. Afterwards, hours worked, weights and quantities of iron, steel, even wicks used, and the material's intended purpose were all carefully tabulated and tracked. ${ }^{150}$ Now everything at the mine became, "regularly systematized [with] greater economy obtained." 151

Watson next took a look at expanding the mine's options underground. Diminishing returns on paying ground compounded the expense hits the mine faced dealing with waste. Mass copper became more elusive as the mine sunk deeper and further north under the Greenstone Bluff. To compensate, attention turned to the amygdaloid floors that ran parallel to the slide but perpendicular to the vein. Earlier in the mine's history, these were generally ignored due to the high cost of stamping mineralized rock. Why bother with stamp work when you have multi-ton masses to cut up all around you? However other mines, like the Isle Royale and Quincy in the Portage Lake District, were making profits off these amygdaloid belts, and Watson saw that if the mine was to continue profitably it would need to stop ignoring these new sources of income. ${ }^{152}$ He set his first sights on the No. 9 Floor, an especially rich belt that demanded special attention due to its unique character. The ore from this floor was worked separately, and then stamped at a secondary mill built near the South Cliff in order to better ascertain its potential. $^{153}$

The results were promising. In order to accommodate their new supply of ore, focus turned toward making the mine's primary stamp mill more efficient. Getting the mill up and running at full speed fell to Joseph Rawlings, who had recently begun his second stint at Cliff and had recently installed the new engines at the Howe Shaft. He

\footnotetext{
${ }^{150}$ Joseph Rawlings, "Recollections of a Long Life," Roy W. Drier, Copper Country Tales Vol I (Calumet: Roy Drier, Publ., 1967) pps. 111-112.

151 Mining Gazette. 4 Feb. 1865.

152 Pittsburgh and Boston Mining Company. Report of the Committee of the Stockholders of the Pittsburgh and Boston Copper Harbor Mining Company. Boston: S.N. Dickinson and Co., 1861. p.7.

${ }^{153}$ Annual Report of 1863, found in Mining Gazette. 23 May 1863.
} 
began by first running the 36 Cornish stamps on a rotation, and never all together at once. Rawlings kept track of every tramcar of ore as it arrived at the mill, and assigned a specific stamp battery for each load. Fuel (cordage) was controlled using bins marked with their storage capacity, refilling them only when completely empty. This allowed for more accurate calculations of fuel consumption, costs per ton, and percentage of yield. ${ }^{154}$

Arguments regarding stamp machinery were taking place all over the Copper Country at this time as younger amygdaloid mines replaced the older fissure mines like the Cliff. Everyone was looking for the most efficient way to break up ore with the question being what has greater importance, quality or quantity? The first steam powered stamp equipment, invented by Edwin Ball in 1857 (Ball's Stamps), were put in place at the Copper Fall's mine in 1861. They're design replaced the need for a camshaft, as steam drove the pestle and stamp shoe both up and down, increasing the force of the blow. They were found to be very effective in working the Ash Bed lode, an amygdaloid deposit requiring a push for quantity over quality. ${ }^{155}$

Other non-steam powered "horned" stamps like those of Hodge's design were also being touted as more effective, since their greater drop crushed more rock per minute, increasing volume. ${ }^{156}$ The Cliff's stamp mill housed 8 of Samuel Hodge's design, but they malfunctioned often, as the force of the drop caused abrasion between the mortars and rods. In order to account for the abrasion, they lowered the height of the drop, which in turn reduced the force of the blow and the effectiveness of the equipment. By 1863 , the mill operated only 4 of them, and decided to rely on the older Cornish stamps instead. ${ }^{157}$

The Cliff was still a fissure mine, amygdaloid floors or not, and quality had to take precedence over quantity. As Nicholas Vivian pointed out in a series of editorial

\footnotetext{
${ }^{154}$ Joseph Rawlings, "Recollections of a Long Life," Roy W. Drier, Copper Country Tales Vol I (Calumet: Roy Drier, Publ., 1967), p.105-115. Rawlings arrived in the Keweenaw in 1850. His first go-around at the Cliff was soon after his arrival, assisting in the installation of either the Avery's or stamp mill's Vivianbuilt engine.

${ }^{155}$ Charles E. Wright, Annual Report of the Commissioner of Mineral Statistics of the State of Michigan, for 1880 (Lansing: W.S. George \& Co., 1881), p.41.

${ }^{156}$ Lake Superior Miner. 12 Oct. 1867. Horns refers to protrusions the cams caught after the rod dropped in order to begin the lift again. The force of this drop and catch was found over time to put quite a strain on the equipment.

${ }^{157}$ Ibid. And, Pittsburgh and Boston Mining Company. Report of the Committee of the Stockholders of the Pittsburgh and Boston Copper Harbor Mining Company. Boston: S.N. Dickinson and Co., 1861. p.9.
} 
rebuttals printed in the Lake Superior Miner, steam stamps didn't merely break up ore to separate copper from rock, they crushed everything to a powder, extruding it through the mortar's sieve. For men like Vivian and Rawlings, who were more familiar with the product of fissure mines, this seemed like a waste. This extrusion increased the likelihood of washing copper away with the rock, thereby losing profits. As for the more forceful drop stamps like those designed by Hodge, Vivian saw nothing but mounting repair bills for broken axles, pestle shafts, and horns. Rawlings agreed, and remarked to Vivian that he worked by the credo, "The lowest lift and the highest weight that will effect [sic] the purpose is the most economical [and] therefore best." The Cornish gravity stamps with their lower drop and replacement costs, fitted with Bessemer steel cams instead of wrought iron and run economically, would just have to do for the foreseeable future. ${ }^{158}$ Although an advertisement in an 1864 edition of the Mining Gazette claimed the Ball's Stamps would save the mine over $28 \%$ in costs, by 1866 the Cliff's costs for stamping by the ton were running 59\% below those of Copper Falls. It appeared for a time that Vivian and Rawlings were on to something. ${ }^{159}$

Another innovation in the dressing of ores came by way of improvements to washing, or jigging, machines. 1864 saw the first advertisement in the Copper Country for George Asmus' Patent Washer, an automated jigging machine. For a cost of $\$ 60$, Asmus offered to either come out and build the machine for you or send the drawings to you so you could build it yourself. Powered by the motion of a stamp shaft, a plunger agitates the copper and rock solution within a 4'6" by 2'4" box, separating "the ore from the substances of less specific gravity, carr[ying] off each [by] a different outlet" (Fig. 212). Asmus claimed each machine capable of handling " $15-20$ tons of ore a day," and although not useful for separating slimes, a hydraulic slime box was offered "without extra expense." 160

\footnotetext{
${ }^{158}$ Mining Gazette. 27 Jan. 1866.

${ }^{159}$ Lake Superior Miner. 26 Oct. and 16 Nov. 1867; Mining Gazette. 18 June 1864. The advert claimed the Cliff would save $\$ 8,980.05$ over a year if it used Ball's Patent Stamp equipment. In 1866, the Cliff's costs for stamping per ton ran 89.71 cents to Copper Falls 94.5 cents. Over the course of a month this amounted to $\$ 83$ a month compared to $\$ 140$.

${ }^{160}$ Mining Gazette. 12 Mar. 1864.
} 
A. W. SCHELL.

Machine for Separating or Cleaning Ores.

No., 1,531.

Reissued Sept. 1, 1863.
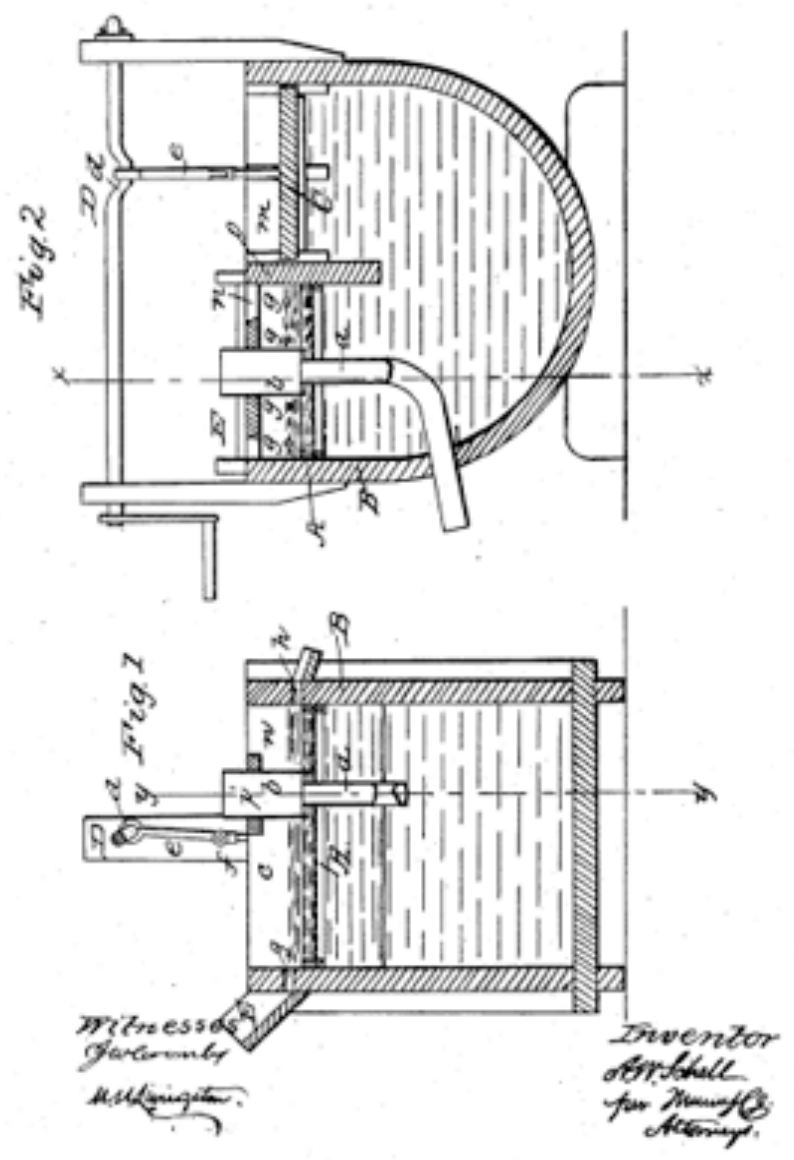

Fig. 2-12. George Asmus', "Machine for Separating or Cleaning Ores." By turning the crank, $d$, the plunger, $e$, agitates the perforated tub, separating the copper from the stamped rock by use of gravity and water. (From US Patent 1531. 1 Sept. 1863)

Asmus finished his ad stating that the Cliff had purchased 4 washers the previous fall and were looking to purchase 8 more. Rawlings helped Asmus install the machines that fall but soon found that they required customizations to the point that, "scarce anything beside the central cylinder is recognizable as belonging to the original." He and the washhouse crew put in a 3 foot square hydraulic separator that divided the grains of 
sand and ore into three sizes before reaching the first of a two stage jigging machine, with waste sand from the first table flowing into the second to be rewashed. To handle the slimes, they built a 120 -foot long launder, suspended by rods, that moved by cams. The slime and water passed through the four-tiered launder while it shook, separating the slime further. A witness to the contraption stated, "An astonishing large amount of very fine copper is caught at the head of the first [tiering], a much less quantity at the next, and so on." The copper concentration in the slime reached roughly 50\%. ${ }^{161}$ Rawlings' handling of the stamp mill and its equipment eventually pushed costs down to their lowest point ever (Table 5). ${ }^{162}$ It seemed as though there was nothing Rawlings couldn't do. Superintendent Watson soon challenged Rawlings to do one better, design and build a man-engine for the Cliff's Avery Shaft. Rawlings had never seen a man-engine let alone designed one but, “as there was only one way to work it, [he] didn't think it a difficult proposition.",163

Used in the copper and tin mines of Cornwall since the 1840's a man-engine made descending into the depths of a mine quicker and, in theory, less dangerous. ${ }^{164}$ Using the pump rods as guides, two perpendicular beams, hundreds of feet long and reinforced with iron, are constantly bobbing up and down in concert with the movement of connecting rods coming off a steam engine's flywheel or pumping beam. Placed at equal intervals of 10 feet are $21 \times 21$ inch wood platforms. On these platforms the miners ride up and down the contraption, stepping off one platform and onto another as the two alternating beams rise and lower. Following this hop-on, hop-off pattern, a miner can descend 700 feet in 7 minutes. ${ }^{165}$

Rawlings first drew up plans of the man-engine, "showing the steam engine in place, the connecting rods, the rods leading to the balance bobs, the bobs in place with

\footnotetext{
${ }^{161}$ Mining Gazette. 4 Feb. 1865.

162 Mining Gazette. 23 May 1867; Pittsburgh and Boston Mining Company. Report of the Committee of the Stockholders of the Pittsburgh and Boston Copper Harbor Mining Company. Boston: S.N. Dickinson and Co., 1866. p.14.

${ }^{163}$ Joseph Rawlings, “Recollections of a Long Life," Roy W. Drier, Copper Country Tales Vol I (Calumet: Roy Drier, Publ., 1967), p.115.

${ }^{164}$ Larry Lankton, Cradle to the Grave: Life, Work, and Death at the Lake Superior Copper Mines. (New York: Oxford Univeristy Press, 1991), p.33. The Dec. $13^{\text {th }} 1866$ edition of the Mining Gazette reported that a rod on the man-engine at the Pewabic Mine broke with men on it and fell 30 feet though no one was injured.

${ }^{165}$ Mining Gazette. 4 Feb. 1865.
} 
Table 5. Showing figures relating to stamping and washing at the Cliff Mine, 1857-1869. There is not enough data from the years 1846-1856 to warrant adding them to the table. Blank cells are unknown values. What can be seen here is that as the quantities of raised copper increase, the inverse is happening to the \% yield after washing. This is due to decreases in stamping/washing costs meaning more ore could be processed, thereby increasing the percentage of stampings that made up the Cliff's annual copper shipments.

\begin{tabular}{|c|c|c|c|c|}
\hline Year & $\begin{array}{c}\text { Raised } \\
\text { Shipped (in } \\
\text { lbs.) }\end{array}$ & $\begin{array}{c}\text { \% Left } \\
\text { after } \\
\text { Washing }\end{array}$ & $\begin{array}{l}\text { \% of Shipped } \\
\text { Copper }\end{array}$ & $\begin{array}{c}\text { Stamping/ } \\
\text { Washing Costs } \\
\text { (per ton) }\end{array}$ \\
\hline 1857 & - & - & $23 \%$ & $\$ 1.23$ \\
\hline 1858 & $28,062,000$ & $3.24 \%$ & $29 \%$ & $\$ 1.43$ \\
\hline 1859 & $27,266,000$ & $2.95 \%$ & $37 \%$ & $\$ 1.31$ \\
\hline 1860 & $37,491,000$ & $2.47 \%$ & $31 \%$ & $\$ 1.40$ \\
\hline 1861 & - & - & $32 \%$ & - \\
\hline 1862 & - & $2.26 \%$ & $41 \%$ & $\$ 1.13$ \\
\hline 1863 & $32,462,300$ & $2.82 \%$ & $31 \%$ & $\$ 1.20$ \\
\hline 1864 & - & - & & - \\
\hline 1865 & $36,570,800$ & $2.33 \%$ & $38 \%$ & $\$ 1.01$ \\
\hline 1866 & - & $2.33 \%$ & $39 \%$ & $\$ 0.89$ \\
\hline 1867 & $32,670,700$ & $2.23 \%$ & $44 \%$ & $\$ 0.78$ \\
\hline 1868 & $27,459,850$ & $2.49 \%$ & $35 \%$ & $\$ 0.97$ \\
\hline 1869 & $22,672,800$ & $2.36 \%$ & $45 \%$ & $\$ 1.45$ \\
\hline
\end{tabular}

their connecting rods, the vertical rods in the shaft with the steps on them eight feet apart, with a man or two upon them, and lastly the masonry, and all necessary odds and ends required." After the company directors in Pittsburgh signed off on the overall design, Rawlings continued making detailed drawings of each element of the machinery. Once these engineering designs were complete, the smiths and carpenters of the mine went about forging and making the necessary materials. New foundations were put in place at the Avery Shafthouse and an old pump engine was remodeled to handle the man-engine's various parts. ${ }^{166}$ This remodeled engine was a 24 -inch horizontal high pressure cylinder with 6 feet stroke, making 18 revolutions per minute. A witness to the equipment described it all thus:

"Attached to the fly wheel shaft, a pinion 2 feet 6 inches in diameter works against a Stuttgarelt spur wheel, 10 feet in diameter. To this spur wheel are attached two wrought iron cranks of 5 feet radius, to which are attached the rods

\footnotetext{
${ }^{166}$ Joseph Rawlings, “Recollections of a Long Life," Roy W. Drier, Copper Country Tales Vol I (Calumet: Roy Drier, Publ., 1967), p.115-116.
} 
connecting with the heads of the king posts. The cylinder takes its steam from the boilers of the pumping engine, located in the same building." 167

Attached to the tops of the $720 \mathrm{ft}$. long spruce beams were $32 \mathrm{ft}$. long oak balance "bob" beams. At the beam's opposite end were large $(7 \times 7.5 \times 5 \mathrm{ft})$ boxes weighted to compensate for the rise and fall of the beams in the shaft. Each beam weighed 12 tons and was designed to handle three times its own weight. If by chance they did break, three separate catches, each capable of a 300-ton impact, were placed at intervals within the shaft. ${ }^{168}$

All told, the new man-engine cost a total of $\$ 30,000$ and was completed by New Year's 1865. Housed in the massive stone Avery Shafthouse, it was run just three times a day during shift-change and when not in use, was locked up tighter than a drum. ${ }^{169}$ Rawlings calculated the mine could discharge all its men in thirty minutes. These men came to see the man-engine as a god send, and even though its platforms may be muddy, it still beat the long climb on ladders whose rungs are slippery and often missing.

Rawlings' design of the man-engine, along with his and James Watson's push towards systematizing the mine workings, kept the Cliff Mine profitable during the turbulent years of the mid 1860's. Workers may have been scarce, but high copper prices meant that even less profitable stamp work, if properly seen to with a focus on cost saving and economy, could compliment harder to find mass copper deposits and make the P\&BMC profits. From 1863-1867, the company declared dividends amounting to $\$ 580,000$ dollars, not too bad for a mine facing a $40 \%$ drop in employment since $1861 .{ }^{170}$

\section{The Declining Years}

James Watson resigned his position as mine superintendent in March of 1866, and was replaced by P. H. Updegraff. Soon after (and not the fault of Updegraff), the mine fell into serious decline with nearly all facets of work struggled with mounting problems.

\footnotetext{
${ }^{167}$ Mining Gazette. 4 Feb. 1865 . This is likely the same engine installed at the stamp mill in 1851 by Nicholas Vivian.

${ }_{168}$ Mining Gazette. 4 Feb. 1865.

169 Mining Gazette. 20 Sept. 1866.

${ }_{170}$ Pittsburgh and Boston Mining Company. Report of the Committee of the Stockholders of the Pittsburgh and Boston Copper Harbor Mining Company. Boston: S.N. Dickinson and Co., Various Years.
} 
Sand continued to obstruct the dock at Eagle River, making the shipment of copper an increasingly costly affair. Underground, greater depths and the need for new paying ground overstretched the workforce. Even the best producing areas of the mine in the late 1860 's, the amygdaloid floors, were no longer cost effective due to a drop in labor force and copper prices. At the mill, 15-plus years of constant grind had taken a toll on the equipment, creating an almost constant need for repairs. To top it off, the once unlimited supply of timber was almost entirely exhausted. The use of coal and the added expense of bringing it in would need to be considered. ${ }^{171}$

Since the earliest years of the mine, Eagle River served as the entry and exit point for all goods coming and going from Cliff. Here, steamers moored to the Cliff dock were loaded with mass, barrel, and stamp copper after offloading machinery, food, and supplies. Over time, the dock became increasingly inundated with sand, forcing awaiting ships to anchor further and further off shore in increasingly shallow waters, while at the same time lessening the tonnage they could carry. ${ }^{172}$ This in turn required small scows to commute back and forth from ship to shore, adding time and costs. During 1863-64, nearly 100 tons of copper had to be left sitting at the dock due tovcproblems with the sand. The P\&BMC suggested building a railroad to Lac La Belle and canal out to Bete Gris (16 miles east) as early as 1863 to alleviate the problem, offering $\$ 30,000$ that year to help fund the construction of a "Keweenaw Point \& Cliff Rail Road." Estimated to cost at least $\$ 500,000$ in total however, the idea never got off the ground. ${ }^{173}$

This failure to invest at this time was due to two events; the dramatic drop in copper prices in 1866, and the initial failure of the Copper Tariff Bill in Congress two years later. During the Civil War, the need for brass and copper telegraph wire upped the demand for copper so much that the price for copper rose from $\$ 0.19$ to $\$ 0.46$ a pound from 1860-65. With the war's end, the demand for copper dropped like a cannonball, its price per pound falling to $\$ 0.28$, a drop of $40 \%$. The Copper Tariff Bill proposed

\footnotetext{
${ }^{171}$ Pittsburgh and Boston Mining Company. Report of the Committee of the Stockholders of the Pittsburgh and Boston Copper Harbor Mining Company. Boston: S.N. Dickinson and Co., 1867.

${ }^{172}$ Pittsburgh and Boston Mining Company. Report of the Committee of the Stockholders of the Pittsburgh and Boston Copper Harbor Mining Company. Boston: S.N. Dickinson and Co., 1866. p.8.

${ }^{173}$ Pittsburgh and Boston Mining Company. Report of the Committee of the Stockholders of the Pittsburgh and Boston Copper Harbor Mining Company. Boston: S.N. Dickinson and Co., 1864. pp.8-10.
} 
imposing taxes on imported copper, thereby giving an advantage to domestic producers suffering the effects of lower copper prices and decreased demand. Smelters in the eastern cities of Boston, Baltimore, and New York, who contracted with both American and overseas suppliers were against the idea, and felt it would cripple their business. In August of 1868, Democrats successfully filibustered the bill and prevented its passage until the next year, but by then it was too little too late for the Cliff. ${ }^{174}$

Underground, increasing depths and cross cutting stretched an already undermanned labor force even further. The mine now reached close to 1,000 feet below the surface. Updegraff reported in 1867 that no further lodes had been found and that all underground explorations were confined to the amygdaloid floors running perpendicular to the vein. Due to the location of what little mass copper there was, most of the material raised from the mine occurred at its deepest point, the Howe Shaft, which unfortunately at this time was in need of serious repair and new timber supports. ${ }^{175}$ To make matters worse, the copper produced per fathom worked dropped 50\% from 1863-67, making the raising of copper in a dilapidated shaft from 1,000 feet down even more costly. ${ }^{176}$

Since 1851, the Cliff's Stamp Mill engine and stamp equipment remained relatively unchanged. While other mines in the Keweenaw and Portage Lake districts increasingly utilized steam powered lift-and-drop stamp machinery, the Cliff continued with their gravity stamps, relying on the rotation of an axle. For a time, this appeared to be the most cost effective equipment available, but as the decade wore on, it became apparent that the relatively ancient equipment was nearing the end of its usefulness. In 1869 , the axle broke at a cost of $\$ 1725.00$. The next year, the mill received an entire overhaul, with new foundations, iron lifters, and heads all installed. It was hoped that Sam Hill, hired to explore the southern extent of the property for the incredibly rich Calumet Conglomerate, would find a supply of ore for the mill to process, but it was not to be. There just weren't any more viable options for the ever-diminishing workforce.

\footnotetext{
${ }^{174}$ Jonathan Leitner, "The 1869 Copper Tariff: The Politics and Geography of Postbellum U.S. Development in World Systems Perspective," Sociological Perspectives 43.3 (2000): 473-497.

${ }^{175}$ Pittsburgh and Boston Mining Company. Report of the Committee of the Stockholders of the Pittsburgh and Boston Copper Harbor Mining Company. Boston: S.N. Dickinson and Co., 1867.

${ }^{176}$ Mining Gazette. 23 May 1863. And, Pittsburgh and Boston Mining Company. Report of the Committee of the Stockholders of the Pittsburgh and Boston Copper Harbor Mining Company. Boston: S.N. Dickinson and Co., 1867. p.10. Lbs per fathom dropped from 1,660 to 800 over this span.
} 


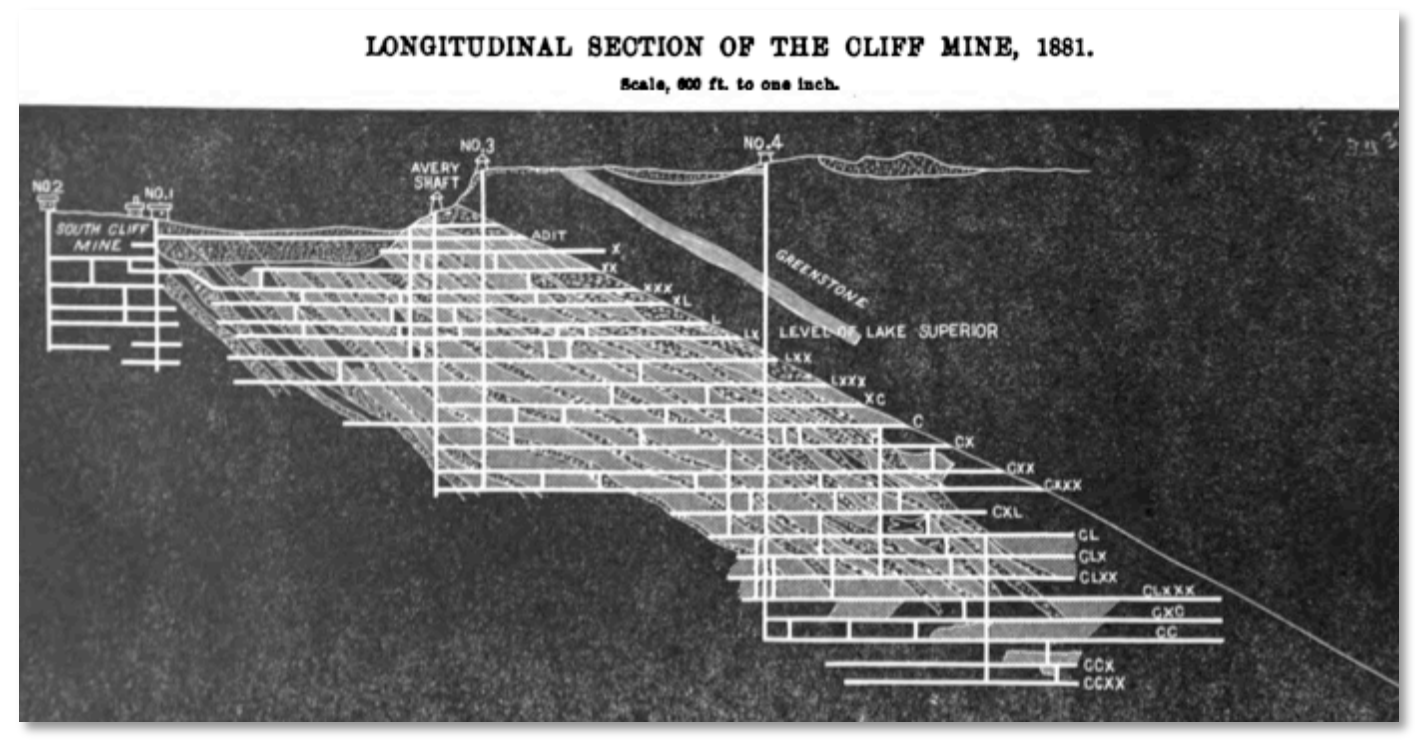

Fig. 2-13. The extent of underground workings at the Cliff Mine soon after the P\&BMC dissolved. (From Charles E. Wright, Annual Report of the Commissioner of Mineral Statistics of the State of Michigan, for 1880. Lansing: W.S. George \& Co., 1881)

Running deficits and low copper prices (now down to $\$ 0.19$ a per pound), forced the Pittsburgh and Boston Mining Company to face what every mine must face at some point, its pinching out. ${ }^{177}$

By 1870 , the mine ran a deficit of $\$ 21,410.11$ while the company's balance sat at $\$ 38,620.00$. The P\&BMC no longer saw the Cliff as a profitable business venture, and offloaded all its holdings (save the North American and North Cliff lands) to Marshall H. Simpson of New York for $\$ 100,000$. For the next 8 years the P\&BMC sat in limbo, as bankruptcy proceedings involving their steamer, Ironsides, and a property dispute regarding the North Cliff kept the company from fully liquidating their assets. Finally in 1879 , the company cashed in their chips and used their remaining balance to pay one last dividend to stockholders, at a rate of $\$ 1.93$ per share. The Cliff Mine's 25 year run (the last 9 being in name only and therefore not counted here) under the ownership of the Pittsburgh and Boston Mining Company had come to an end. ${ }^{178}$

\footnotetext{
${ }^{177}$ Pittsburgh and Boston Mining Company. Report of the Committee of the Stockholders of the Pittsburgh and Boston Copper Harbor Mining Company. Boston: S.N. Dickinson and Co., 1867. p.6-8, 17, 21-25.

${ }^{178}$ Pittsburgh and Boston Mining Company. Report of the Committee of the Stockholders of the Pittsburgh and Boston Copper Harbor Mining Company. Boston: S.N. Dickinson and Co., 1879. p.4-7. And, J. Fisher,
} 


\section{The Cliff Copper Company and Calumet \& Hecla Periods}

Simpson reorganized the mine in 1872 as the Cliff Copper Company, with $\$ 500,000$ in working capital divided into 20,000 shares. Simpson hired Oliver A. Farwell, formerly of the Phoenix Mining Company, to oversee the 250 men employed to keep the Cliff alive. After a 14 month dewatering of the mine (it sat unattended for a year), work focused on the masses of copper still lingering in the recesses of the workings. In all, $5,700,000$ pounds of copper were removed from the mine between 1873-1880, but low copper prices (\$0.23 per pound) and a dwindling workforce (it dropped from 250 to 50 over five years) meant the Cliff Copper Company would be hard-pressed to succeed. The stamp mill shut down for good in 1876, and by 1879 the mine continued on under the tribute system. $^{179}$

After Farwell's death in 1881, Daniel Brockway, a well-known businessman in the Keweenaw, became agent of the Cliff Copper Company. Activity centered on opening up promising new veins and lodes. Diamond drill teams active along the southern boundary of the property hoped to find the conglomerate and amygdaloid lodes being worked in the Portage Lake mining district to the south. ${ }^{180}$ Nothing came of it though, and by the turn of the century the owners of the Cliff Mine stripped the buildings of all machinery and passed the property on to the Tamarack Mining Company, who continued diamond drilling from 1903-1907. ${ }^{181}$

From 1907-1910, the Tamarack Mining Company began work at the Avery and South Cliff No. 1 Shafts. The two shafts were connected via a drift at the 3 Fathoms level, just under the west branch of the Eagle River, in order to work the $9^{\text {th }}$ and $13^{\text {th }}$ amygdaloid floors, which ran perpendicular to the Cliff Vein. During the first year of operations the company erected two boarding houses, a rock house, and a new wood frame shaft house over the Avery replacing the four-story collapsed stone behemoth that

Historical Sketch of the Lake Superior Copper District (Houghton: Michigan College of Mines , 1924), p.246-247.

${ }^{179}$ Don H. Clarke, Copper Mines of the Keweenaw, The Cliff Mine (1976), p.26-28.

${ }^{180}$ Donald Chaput, The Cliff: America's First Great Copper Mine (Kalamazoo: Sequoia Press, 1971), p.103-105.

${ }^{181}$ J. Fisher, Historical Sketch of the Lake Superior Copper District (Houghton: Michigan College of Mines , 1924), p.247. 
once housed the man-engine. For the next $3 \frac{1}{2}$ years, the company attempted to revive the mine, but after expenditures of $\$ 172,515.97$, no rock of commercial value was found. ${ }^{182}$

1910 saw the Tamarack Mining Company's Cliff Mine operations restructured as the Cliff Mining Company after its holdings were transferred to the Calumet \& Hecla Mining Company, at the time the largest and most profitable copper mining operation in the Upper Peninsula. Calumet \& Hecla $(\mathrm{C} \& \mathrm{H})$ put forth $\$ 2,500,000$ in working capital and went about searching for new ore bodies to the north and south of the "old Cliff.",183 In the early years, most of the company's capital went towards exploration and development work. A new shaft with boiler/engine plant was sunk on the Kearsarge Lode, but after a depth of over 200 feet, nothing of worth had been encountered. Work at the mine sputtered on and off from 1916 to 1927, when C\&H began a large-scale geologic survey of the Keweenaw. Hopes were raised that this survey would revive mining in the district. $\mathrm{C} \& \mathrm{H}$ even toyed with the idea of purchasing the Keweenaw Central Rail Road, which passed through Clifton, with the old mine its intended beneficiary. ${ }^{184}$

Using the Avery and Howe shafts as entry points, C\&H dewatered the mine with electric pumps set up at the base of the bluff. The pumps rose water from below the $13^{\text {th }}$ level beneath the Howe and then brought it over horizontally to the Avery where it finally exited the workings. Although there were surface plants at both shafts, all mine work occurred at the Howe. ${ }^{185}$ The new operations were set up over the original mine buildings, the electric pump house sitting between the Avery Shaft and its engine house even using an original stone stack base for their compressors. At the Howe, waste rock raised from the mine partly buried the original surface plant, a symbolic statement of C\&H's supplanting of the P\&BMC as top dog in copper mining.

Over the next 4 years the mine sunk nearly 800 feet below the $20^{\text {th }}$ level, with another 1,500 feet of cross cutting taking place east and west of the vein eventually hitting the Calumet Conglomerate Lode, the very ore body that made $\mathrm{C} \& \mathrm{H}$ rich half a

\footnotetext{
${ }^{182}$ Calumet And Hecla Mining Company, "Tamarack Mining Company." Annual Reports for the Year Ending April 30, 1909-1912. 48-58. Boston.

${ }_{183}$ Cliff Mining Company, Annual Report for the Year Ending December 31, 1910. Boston. p.3.

184 Ibid. 1911-1927.

${ }^{185}$ Ibid. 1927-1928.
} 
century earlier. In 1932, after spending nearly $\$ 750,000$ in trying to revive the Cliff Mine, the Calumet \& Hecla Mining Company suspended operations. For the next 29 years the property sat idle, with the last annual report of the Cliff Mining Company coming in 1951. The Cliff's 105 -year lifespan had come to an end. ${ }^{186}$

${ }^{186}$ Ibid. 1910-1951. 


\section{Chapter 3:}

\section{Field Work and Documentation}

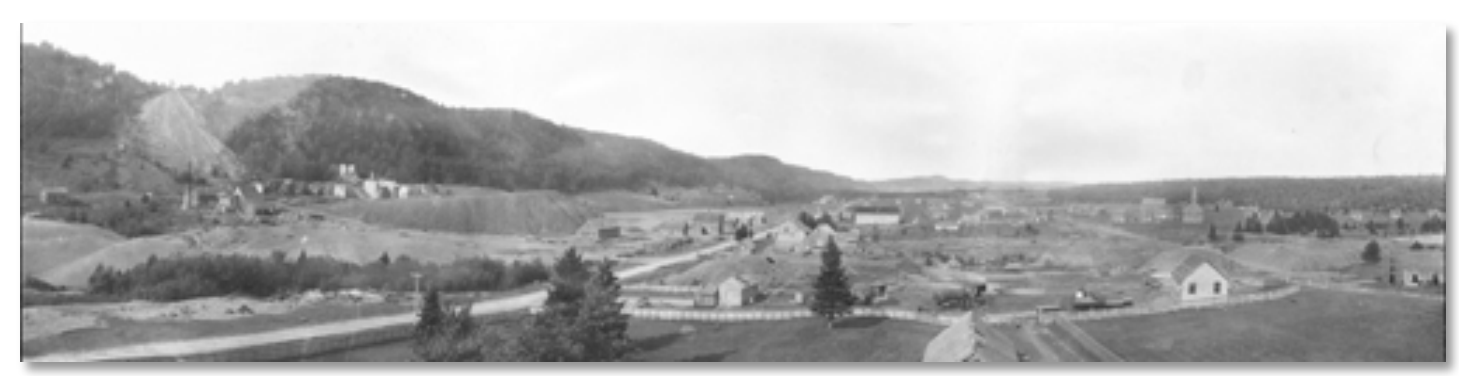

Fig. 3-1. Panoramic view of the Cliff Mine (far left) and townsite of Clifton. Created by merging three J. T. Reeder photographs taken in 1906. (Michigan Tech Archives and Copper Country Historical Collections)

"The workmen are generally robust and hardy, but rough in their appearance and manners; yet, under the rough exterior are some noble minds and generous hearts. To get a good view of them as they issue from the mine, you should be at a prominent place at the ringing of the dinner-bell. You may see them coming from the mine, covered with mud and dirt, and often drenched from head to foot. The workmen now, generally in single file, make a straight wake for their boardinghouse, crossing each other's path in all directions. If one did not know better he would suppose them to be inhabitants of a world where the sun's rays never reached; and they are, eight hours out of twenty-four."1

\section{Methods}

The methods for research of the Cliff Mine fell into two distinct parts: the analysis of historical documents related to the site, and six weeks of on-site field work in conjunction with an archaeological field methods course taught by the Michigan Technological University's Department of Social Sciences in the Spring of 2010. Analyses of historical documents were used for identifying and locating structures and features related to the industrial processes of mine. These documents as well as historic photographs identified in the Michigan Tech Archives \& Copper Country Historical Collections were useful as guides for setting up distinct operational zones of the site for the field season.

\footnotetext{
${ }^{1}$ Rev. John H. Pitezel, Lights and Shades of Missionary Life: Containing Travels, Sketches, Incidents, and Missionary Efforts During Nine Years Spent in the Region of Lake Superior (Cincinnati: Western Book Concern, 1857), p. 168.
} 
Knowing that the operation of the site fell under three distinct periods also facilitated the separation of features found on site into the early (P\&BMC control), middle (tribute/Cliff Copper Co. control), and late (C\&H control) periods. Understanding these distinct periods and their related features was integral in identifying the technical networks of the P\&BMC period. Some early photos taken at the Cliff (as early as 1857 in some instances) show the surface features of the mine at the height of its operation. Photos found in the J.T. Reeder Collection (housed at the Michigan Tech Archives) covered a time span of over 30 years (roughly 1900-1937), and documented both the middle and late periods of the mine's occupation. Confusing tramways and foundations associated with the Cliff Copper Co. or Calumet \& Hecla Co. with those of the P\&BMC would compromise interpretation of the P\&BMC's approach to the challenges brought on by the Greenstone Bluff. With the help of these early photos and those of the J.T. Reeder Collection, the divisions between periods could be made easily.

Historical documents relating to the technical processes and changes made at the Cliff Mine are mostly in the form of the P\&BMC's Annual Report to Stockholders and newspaper articles from the 1840's-1870's. Again, the Michigan Tech Archives and Copper County Historical Collections housed the largest collection of these documents. Annual Reports for the majority of years of the P\&BMC's operation exist at the Archives and give a year by year account of the financial standing of the company, the movement of underground operations at the mine, and the improvements made at the mine's surface. Newspaper accounts were helpful in following the weekly activities of the mine and tracking many of the construction projects/technological changes taking place on the surface.

\section{General Field Protocol}

Documentation of the Cliff Mine site took place from April 30 to June 26, 2010, with the period from May 10 to June 24 also functioning as the archaeological field methods course for Michigan Tech's Social Sciences Department. The field crew during the field methods course consisted of 12 individuals made up of undergraduate and graduate students, volunteers, and Michigan Tech faculty. Field work was organized into 


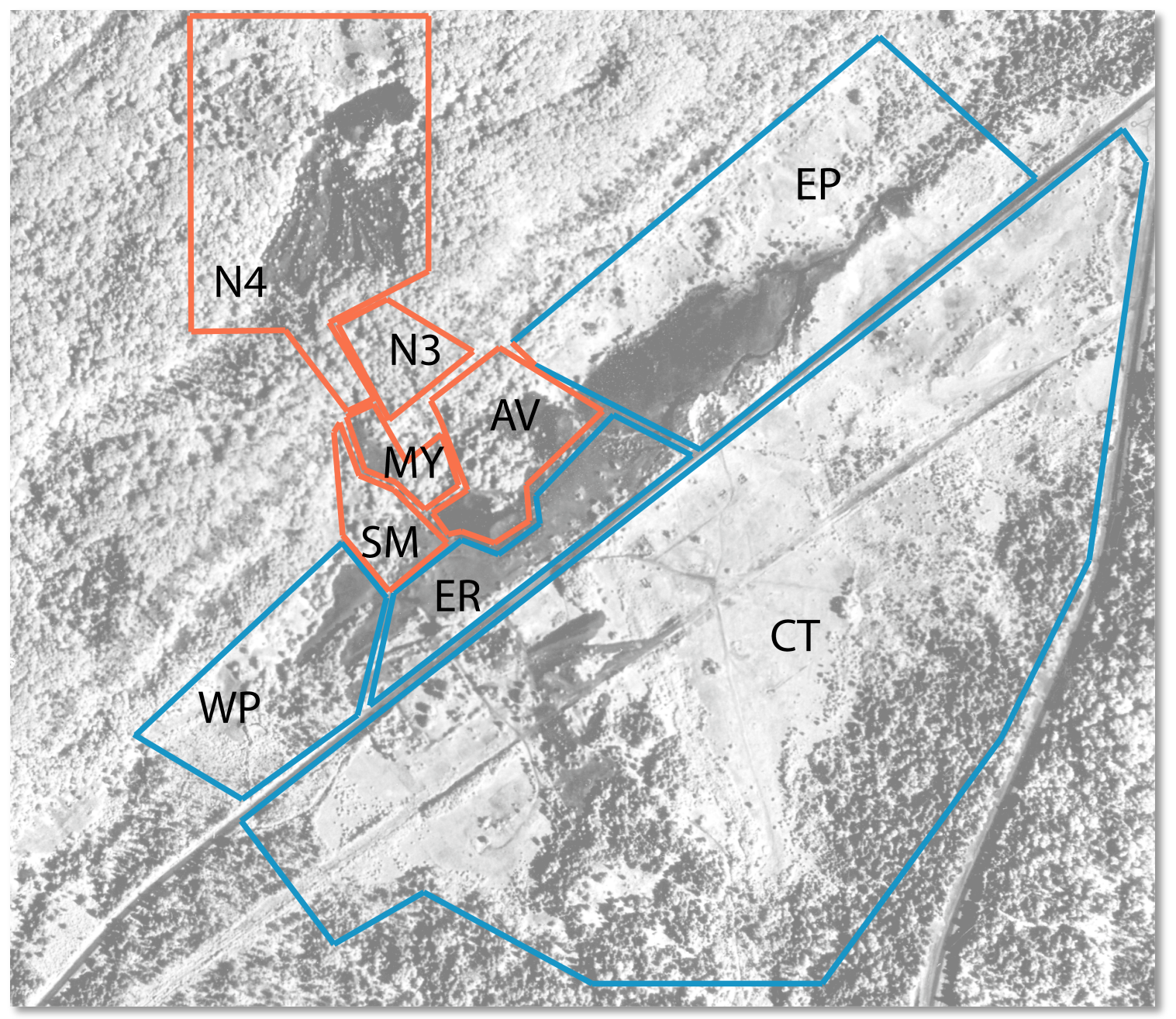

Fig. 3-2. Operaional Zones of the project created using 1954 aerial photo of the Cliff Mine site. Those outlined in red are part of the site's industrial core. Those is blue are peripheral areas and the townsite of Clifton. Rock piles and stamp sand (darkest areas) are visible along with roads in the townsite. (Image courtesy of Michigan Department of Natural Resources and Environment)

two general projects: mapping previously identified industrial features with both digital mapping technologies and traditional field methods, and conducting a pedestrian surface survey in order to identify and map (using traditional methods) the Clifton town site located to the south of the Cliff Mine's industrial core.

As mentioned previously, in order to help organize fieldwork over a large area the site was divided into distinct operational zones (henceforth termed $\mathrm{OZ}$ and seen in Fig. 32). Roughly half of the OZs focused on industrial areas of the site while the remainder were dedicated to the town site of Clifton and the site's peripheral (and non-industrial) 
areas. At the onset of the field season the industrial areas of the site were divided into 3 OZs determined by the location of mine shafts: The Avery (and nearby No. 1 and No. 2 shafts), the No. 3 (at the top of the bluff), and the Howe (1000 ft. NE of the No. 3). By the second week, it was determined that this was too general as the Avery Shaft Surface Plant covered the entire surface operations at the base of the bluff, and was therefore too large to be grouped as one OZ The Avery Shaft Surface Plant was further divided into three zones: the Avery, the Mineral Yard, and the Stamp Mill.

The peripheral areas of the site and the town site of Clifton were included in the fieldwork in order to provide an opportunity for the field school participants to learn mapping skills as well as identification of features not related to the technical processes of hard rock mining. These OZs contained features related to the everyday lives of those who lived and worked at the mine, though it was later found that these areas contained industrial features as well including shafts, engine houses, and support buildings previously unknown at the outset of the field season.

\section{Photography}

A brief mention of the field photography should be made at this point. The landscape of the Cliff Mine site, consisting of rock piles, woodland, swamp (often in one place) can make photography difficult, if not impossible at times. The timing of the field work, in the middle of Spring, compounded difficulties with photography as vegetation gradually overtook much of the site. As per the field school's curriculum, field photography of the site's industrial core was carried out in order to provide the class with practical experience. It is hoped that in the future, when the vegetative cover is less obtrusive, new field photographs can be taken. However for the purposes of this project, a selection of photographs from the May/June 2010 field season are included in Appendix B.

\section{Mapping with GIS and GPS}

The primary goal of digital mapping at the Cliff Mine site is to understand how the Pittsburgh \& Boston Mining Company adapted to the challenges presented by the 
landscape (mainly the Greenstone Bluff) and the nature of the Cliff (copper) Vein. Additionally, it is hoped that mapping will assist in interpreting the site for the general public, since although no agency or organization has currently designated the site the site as a tourist attraction; visitors to the site are common. Interpretation of the site with the help of high resolution mapping technologies may influence future activity and prevent the misuse of the sites resources.

The present-day condition of the site is vastly different from that of the mine's operation, as woodland has attempted to reclaim much of the site's landscape. The waste rock piles located atop and below the Greenstone Bluff have also been modified by human activity, and bear only a partial resemblance to historic photos taken of them during the first half of the twentieth century. Currently, logging is also taking place in and around the former property of the $\mathrm{P} \& \mathrm{BMC}$, creating an urgent need for documentation of the site.

Two technologies were used during the field season in order to map the site: a handheld Global Positioning System (GPS) unit, and a Topcon 2009-GPT Total Station. Both technologies provide spatial data in the form of collected points stored within a software package that can be exported to a Geographic Information System (GIS), in this case, ArcGIS. Using the point data collected via the GPS and Total Station units, a virtual representation of the mine can be created with real-world coordinates with the help of ArcMap, (one program in the ArcGIS software package). These point data can also be combined with historic photos, maps, and aerial images to create overlays of the surface features at the site in order to better understand their spatial relationships to one another and assist in interpretation.

The mapping crew divided work amongst the GPS and Total Station units based on priority and size/scope of features. The GPS unit was used primarily on the peripheral areas and Clifton town site while the Total Station was used within the industrial operational zones. For comparison's sake, GPS data was also collected in many of the industrial OZs and used in order to "check" the Total Station data. Together, the point data from the Total Station and GPS were then combined to create a site map. 
Measured drawings in the form of plan and profile views were made of a number of industrial features determined to be of primary importance to the understanding of the mine's technical systems. Optical transit, compass, electronic distance measurers, and tape were the tools utilized by field crewmembers to create these drawings. The aim of the plan drawings was to compliment, and in some cases compare to, the GIS data. Sketch maps made with compass and tape were also made of the features within the peripheral areas and Clifton in order to recreate the community's layout and possibly identify industrial features and technical networks outside the site's industrial core. 


\section{Operational Zones ${ }^{2}$}

Avery Shaft Surface Plant

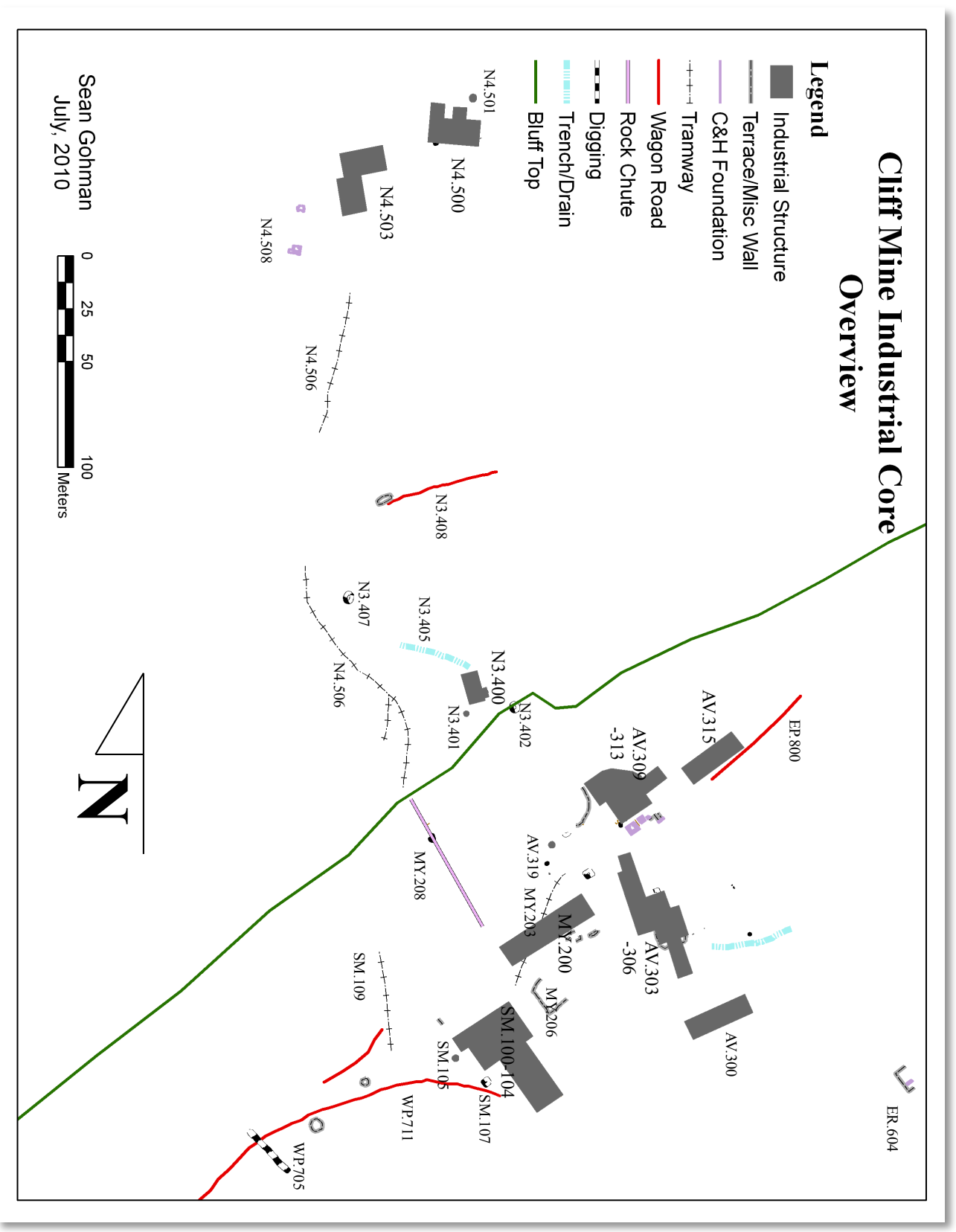

Fig. 3-3. (Image by Author).

\footnotetext{
${ }^{2}$ Each operational zone's features are listed in Appendix B, found at the end of this document. For ease of reading, the feature's description, instead of their feature number, has been included in text. Additional historic images can be found in Appendix A.
} 


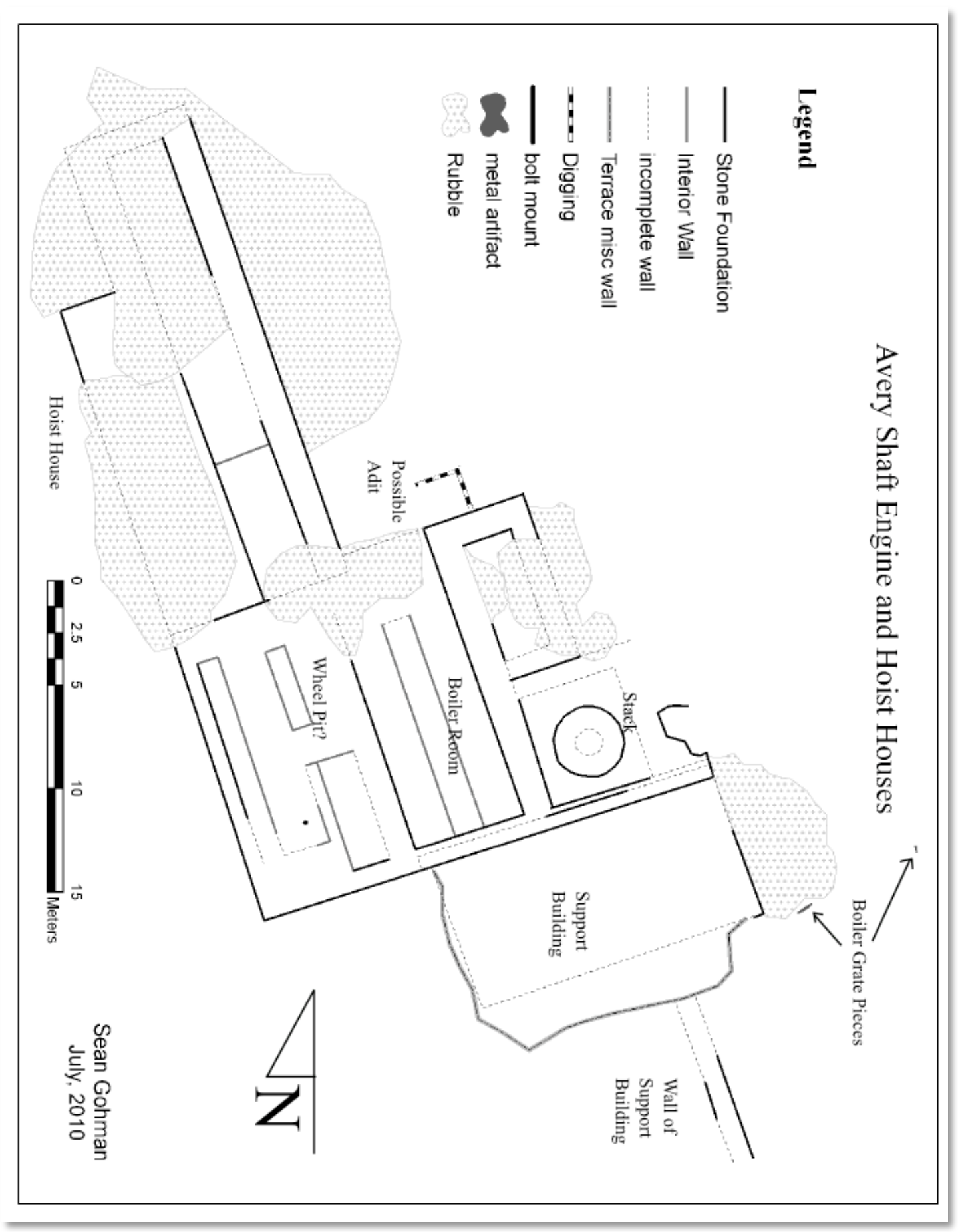

Fig. 3-4. (Image by Author). 


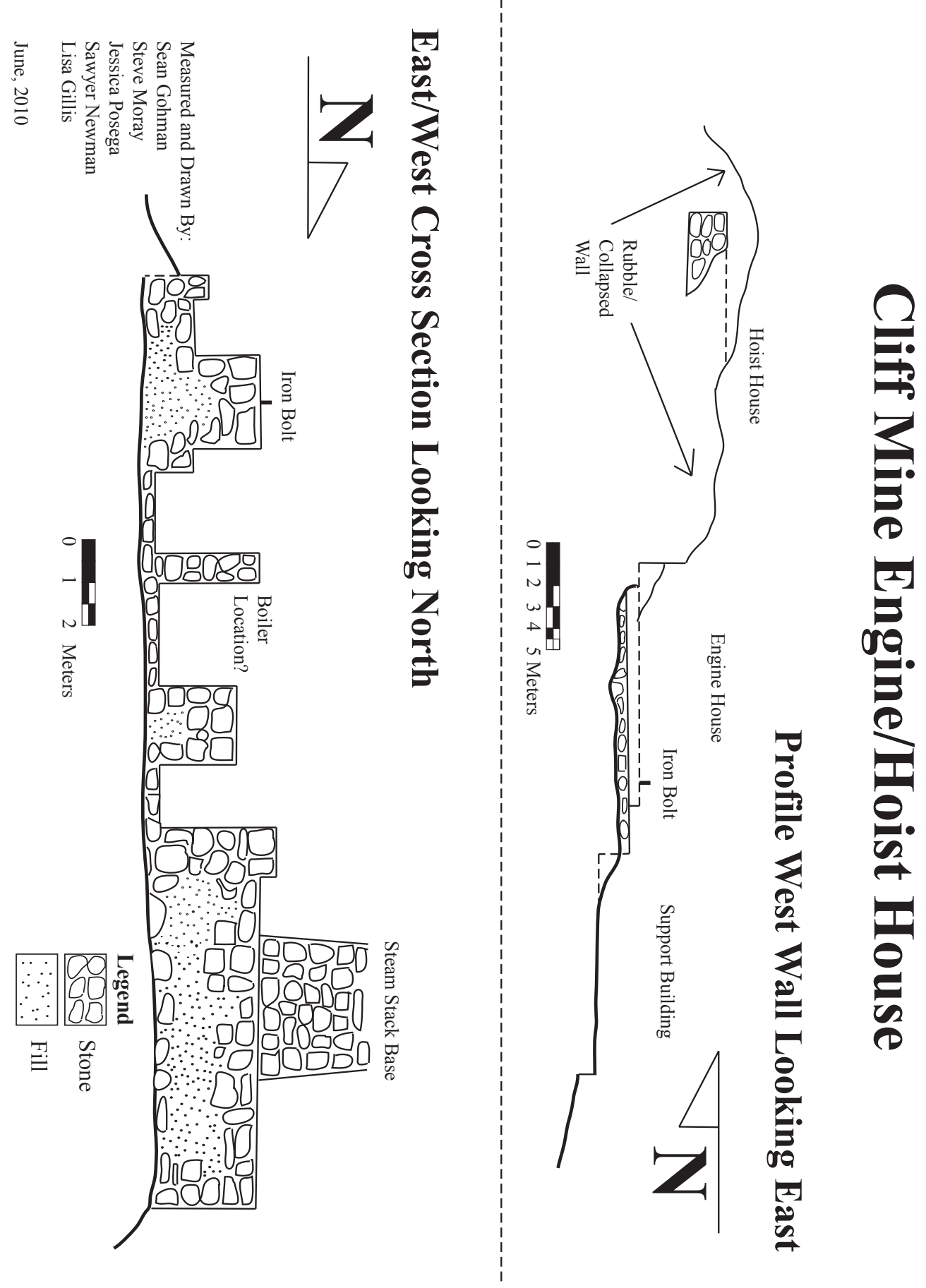

Fig. 3-5. (Image by Author). 
In terms of industrial occupation and use, the Avery Shaft surface plant operational zone is the primary site in understanding the technical systems of the Cliff Mine. Within this zone were the original shafts of the mine, the No.'s 1 and 2, the Avery Shaft, and its massive stone shaft house begun in the late 1850's, the mine's machine shop, first engine and hoist houses, earliest mine offices, and boarding houses (Fig. 3-3).

The primary shafts and associated structures were the heart of the copper mine, and often underwent the greatest number of changes and improvements over the mine's lifespan. Narrow $6 \times 7$ foot shafts, accessible only by ladder, were later replaced by wider openings with steam powered man-engines taking miners down into the mine's depths. Man and horse-powered whims and capstans acted as hoisting equipment in the earliest stages of a mine until iron skips powered by steam engines and hoists are affordable. Emanating from the surface workings were tramways to transport masses of copper, stamp rock, and waste rock to the mineral yards, stamp mills, and waste piles of the mine, covering the remains of older structures and earlier pathways as they grow.

GIS Total Station mapping occurred over a two-week period at this operational zone, and documented features such as mine shafts, stone foundations, steam stacks, wagon roads, and concrete foundations associated with the Calumet \& Hecla period of operation in the 1920's and '30's. Measured drawings, in profile and cross-section, were made of the engine/hoist house's western and southern walls (Figs. 3-4, 3-5).

The stone engine house (Fea.AV.304), built in 1851, originally housed two engines, one for pumping water from the mine, the other a large vertical beam engine built by Nicholas Vivian to power the hoisting in No.'s 1 and 2 Shafts. ${ }^{3}$ The dimensions of the stone foundation remains are $22.5 \times 14.5$ meters, and it was divided into two halves. The eastern half likely housed two boilers and the main engine (Figs. 3-6), with the western half accommodated the engine's walking beam. This beam would have been attached to either a wheel or series of connecting rods in order to drive the rotation of whims and pulleys attached to iron kibbles in the shaft. Pumping would have occurred through a depression on the NW corner of the structure, a possible adit. A 3.4 meter diameter steam stack (Fea.AV.305. Fig. 3-7) connects to the boiler room on the east, and

\footnotetext{
${ }^{3}$ Lake Superior Journal. 13 Nov. 1850.
} 


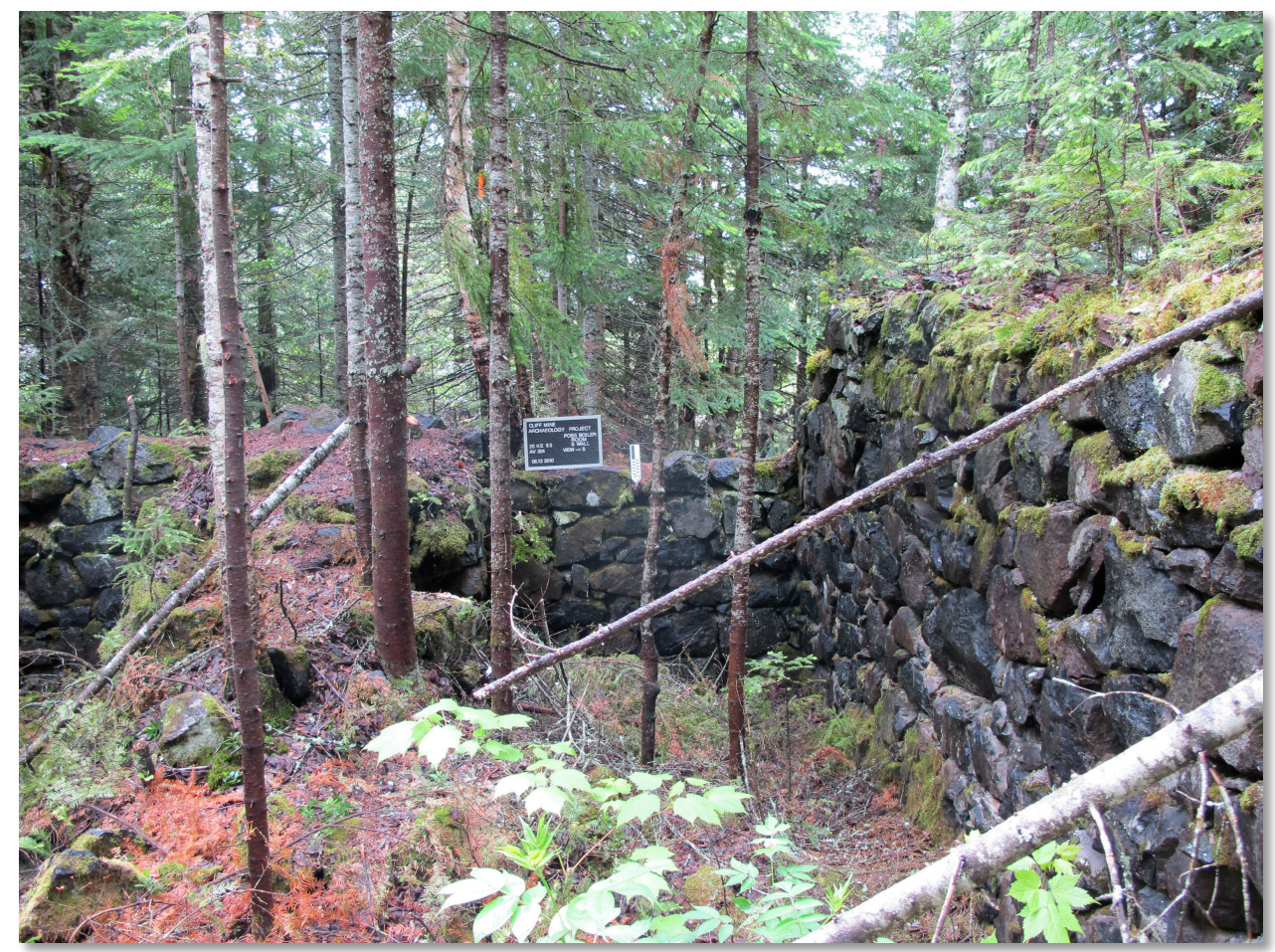

Fig. 3-6. Fea.AV.304. Boiler room for the engine house, from the north. (Image by J. Baeten).

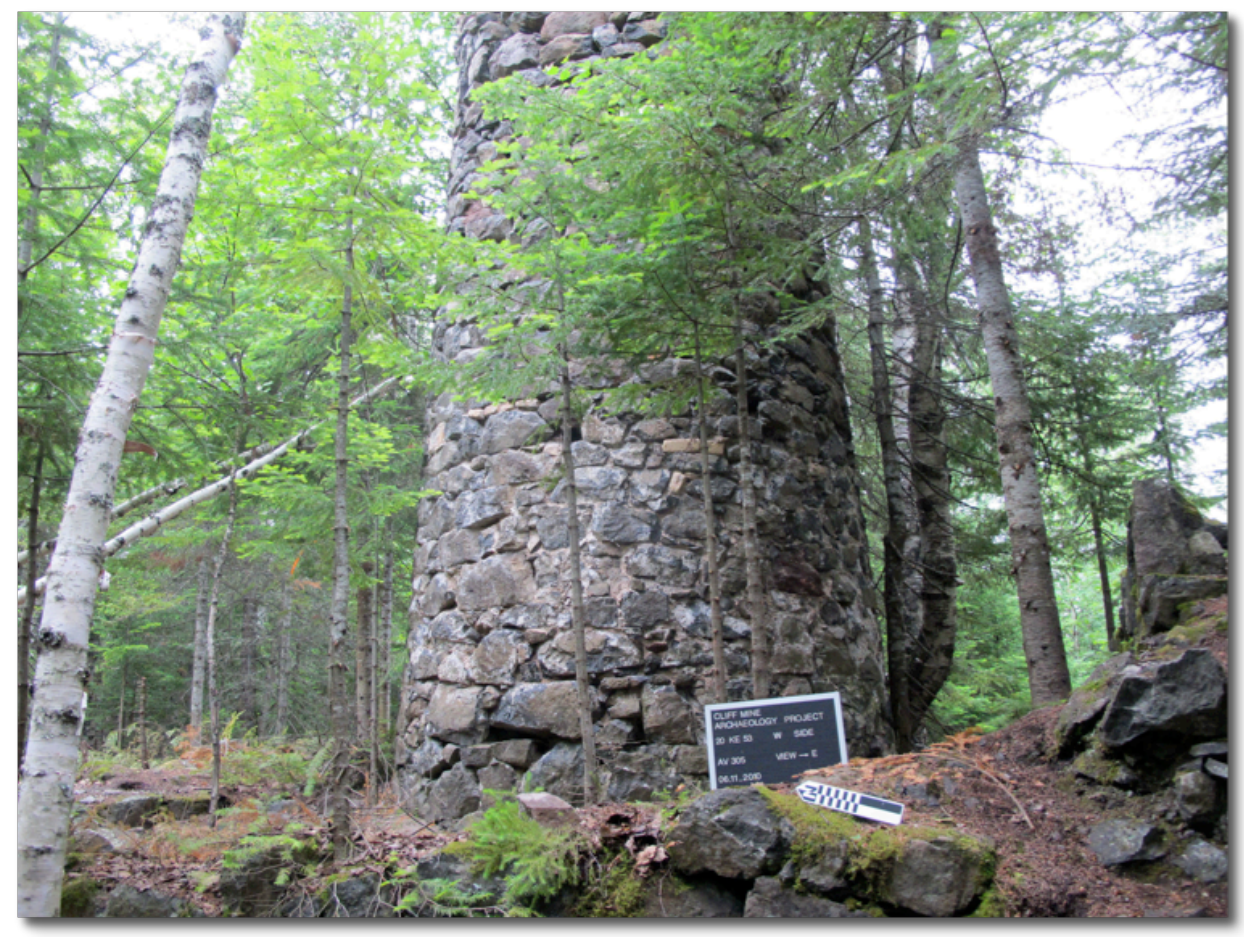

Fig. 3-7. Fea.AV.305. Avery engine house's 3.4 meter diameter smoke stack, from the west. (Image by J. Baeten). 
is the only stack on the site which still has a metal top protruding from its stone base column.

To the south of the engine house were two support buildings of unknown purpose (Fea.AV.303). Likely used for storage of timber and later coal, neither structure was as sturdily built as the engine house, and neither feature's remains are visible except for earthen mounds/terraces. Below and to the east of these features were found two large pieces of steam boiler, almost completely buried, as well as fragments of the boiler's fire grates (Fea.AV.301). The boiler most likely originated higher up the bluff as part of the Avery Shaft house's pump house.

With the sinking of the Avery Shaft in the late 1850 's, a $16.5 \times 9$ meters stone hoist house was attached to the engine house (Fea.AV.306). From this building a large hoist drum would have been placed to raise and lower equipment via wire rope and chain. The remains of this structure are for the most part buried beneath earth and rubble, as the building appears to have collapsed in on itself. Along the western foundation wall, 4 iron rods were found and are likely the attachment points of the winding drum and hoist machinery.

Lying between the hoist house and bluff are the collapsed remains of the Avery Shaft house (Fea.AV.309). Originally a four-story stone behemoth, only stone rubble and corridor remain (Fig. 3-8). The shaft itself was long ago filled in and capped by the Calumet \& Hecla Mining Company. An associated stone retaining wall just north of the shaft has now partially collapsed over the shaft (Fig. 3-9). Following the retaining wall east, it becomes apart of a corridor that was the probable miner's entrance to the shaft (Fea.AV.313. Fig. 3-10). If this is the case, the man-engine would also have been placed within this corridor. The men would have walked through the corridor and then stepped onto a man-engine platform in order to descend into the mine. The man-engine's balance bobs, measuring over 10 meters in length, likely "balanced" on the southern side of the corridor, a 2.5-meter thick wall that is currently in a state of severe collapse.

To the east of the possible entrance is a room measuring $8.5 \times 7$ meters and may have been a change, or dry, room (Fea.AV.310). Below and to the south of this is the likely location of the boiler room for the shafthouse complex. Calumet \& Hecla 


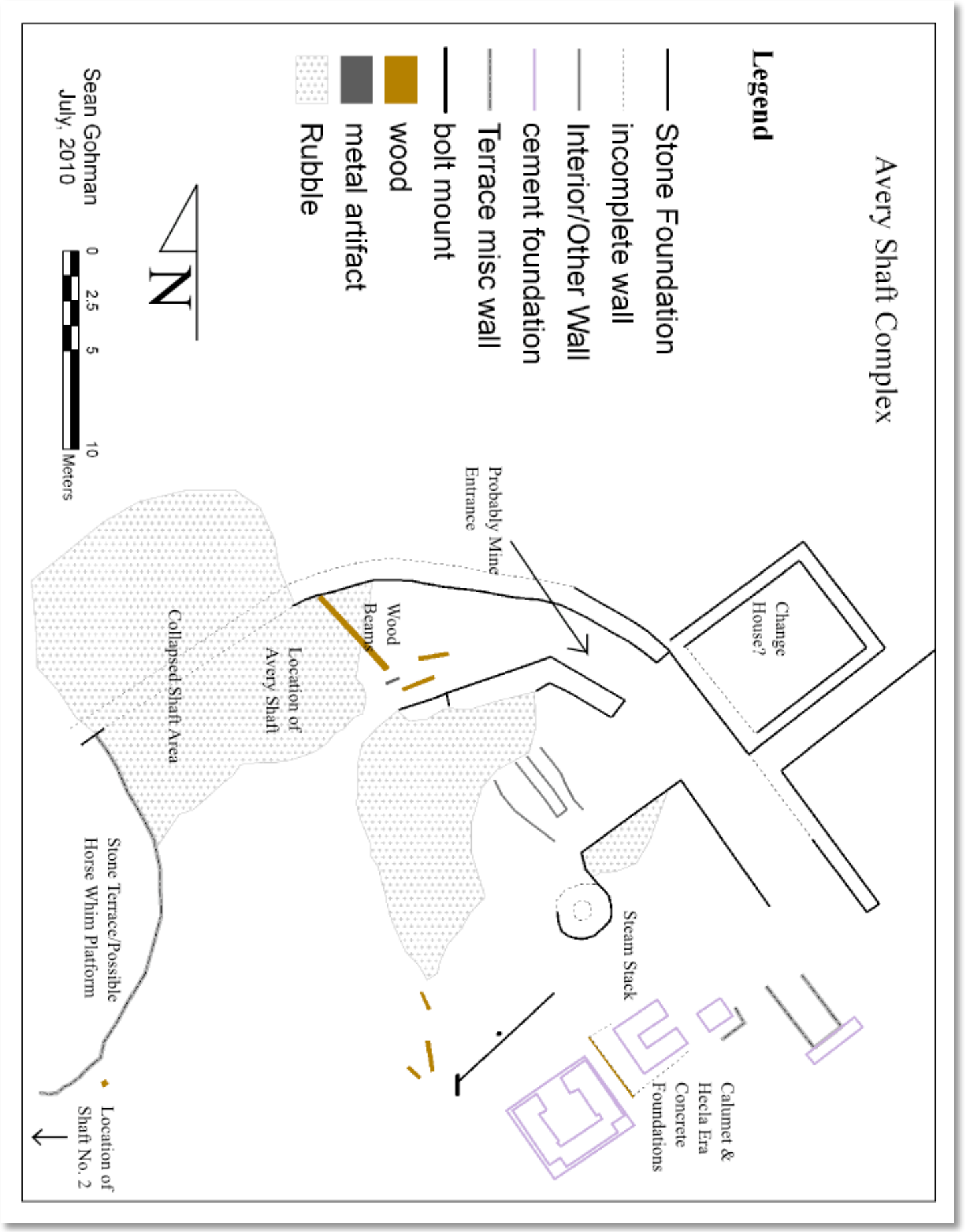

Fig. 3-8. (Image by Author). 


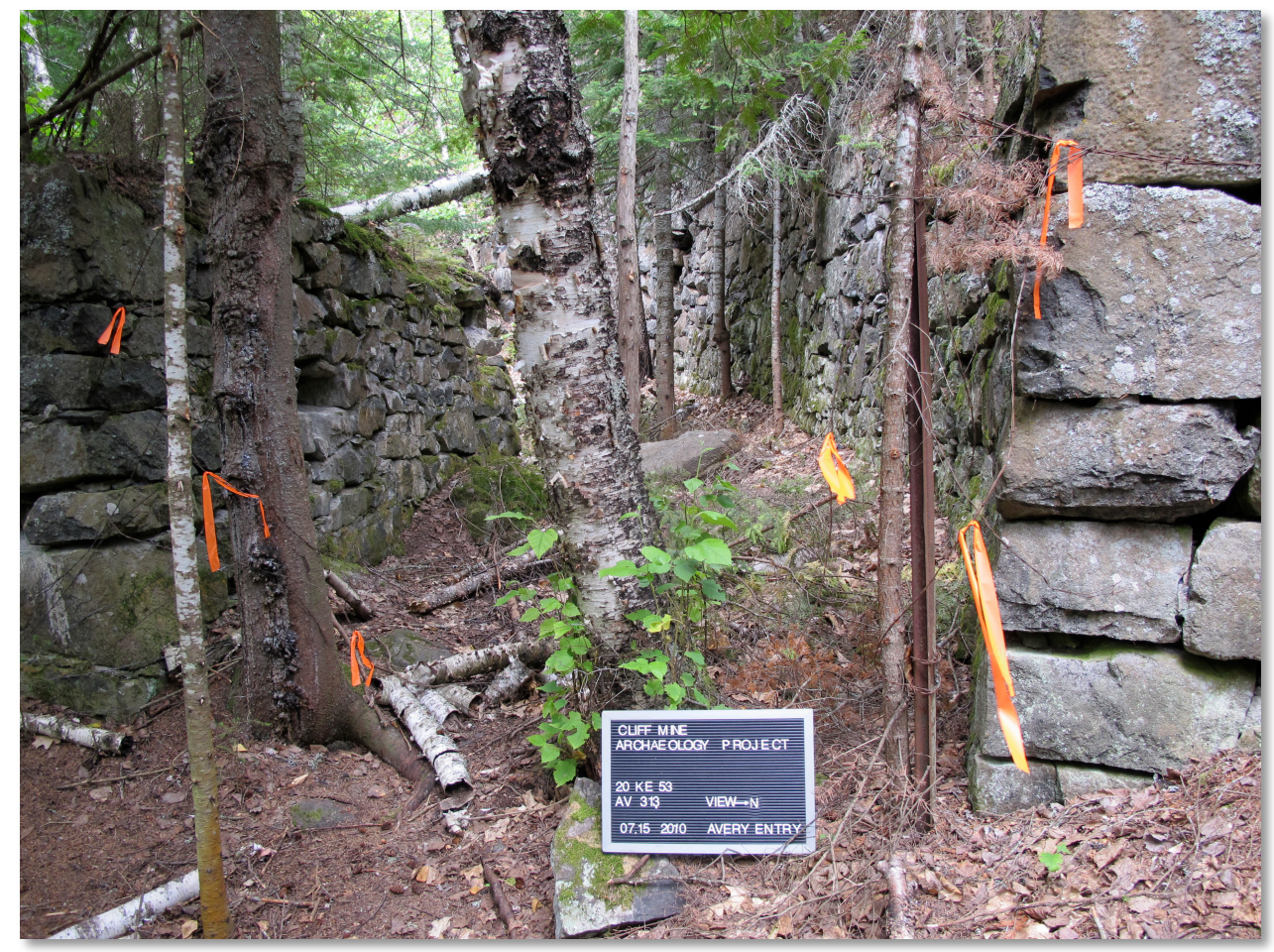

Fig. 3-9. Fea.AV.313. Possible entrance into the Avery Shafthouse, from the south. The flagging marks barbed wire wound across the entrance. (Image by Author).

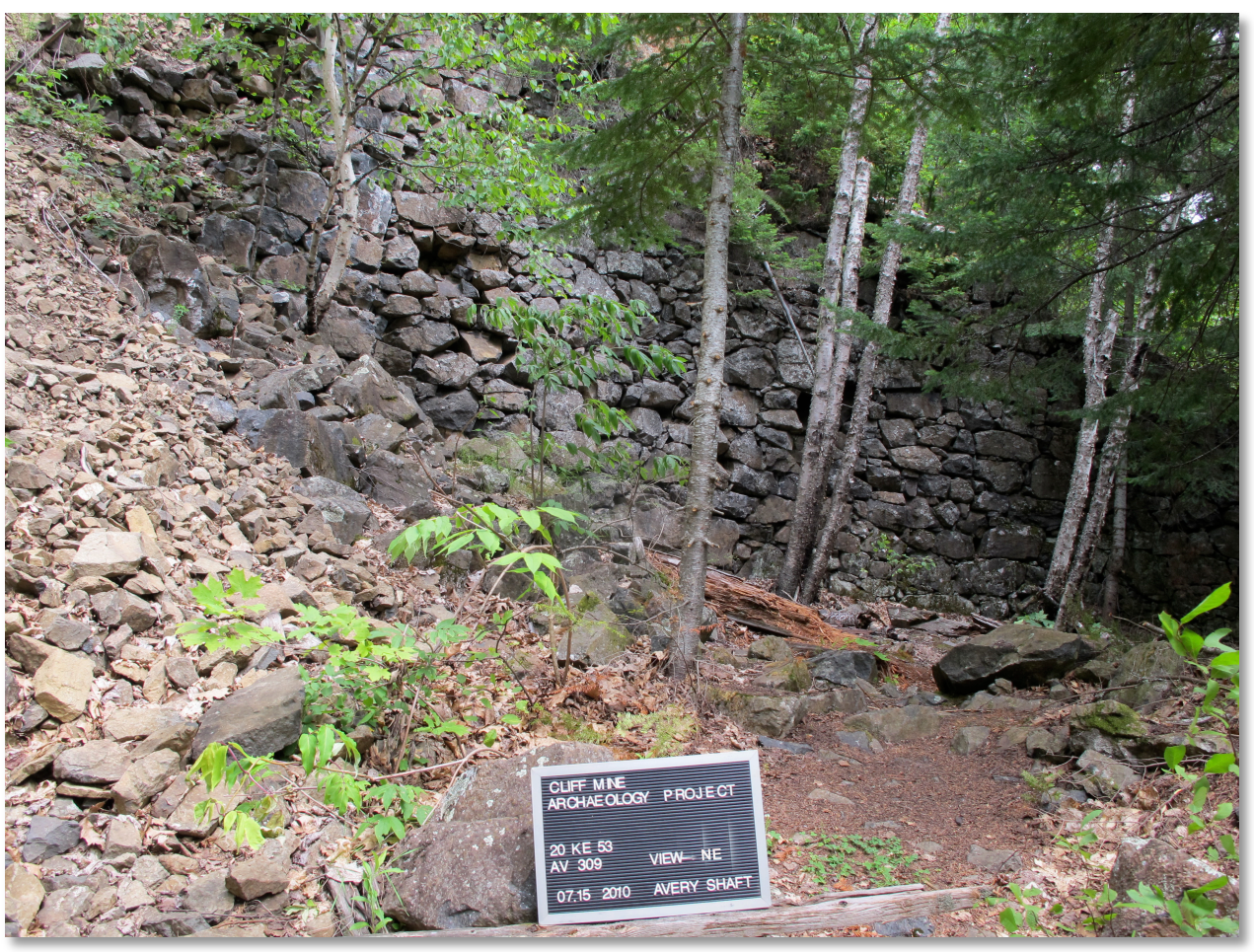

Fig. 3-10. Fea.AV.309. Avery Shaft and retaining wall, from the southwest. The shaft has long since been filled and covered with collapsed rock. The man-engine probably sat at center right with its balance bobs at far-right extending out of frame. (Image by Author). 
demolished and built on top of this area in 1927, but an historic photo from 1923 shows a large boiler located there. These boilers provided steam for the pumping and manengines, and were relieved of their exhaust gases by a large smoke stack with wide flue remains (Fea.AV.312). This 3-meter diameter stack was later repurposed by Calumet \& Helca for their compressor house, with mortar from their adaptive reuse still visible. The C\&H period compressor house's concrete foundations, spiked with iron machine mount bolts, still resides in the former boiler house as well (Fea.AV.311).

Moving east from the Avery Shaft is the 29.2x 9 meter machine shop, sitting along the wagon road that once led to Eagle River from the mine (Fea.AV.315. Fig. 311). This one story, three-room structure, built in 1856 and enlarged by 54 feet in 1863 , was the site of tool manufacture and repair, with the maintenance of drills and chisels its primary purpose. ${ }^{4}$ The feature has been the victim of significant looting and scavenging over the years, not a surprise considering the prevalence of metal tools and equipment that would have been housed there. Of note is the northern foundation wall, where the wall tapers through a series of steps over a height of 1.5 meters. This feature is not found on its parallel wall to the south, and may have been built for extra support/defense against falling rock from the bluff above. ${ }^{5}$

To the west of the Avery Shaft were the No.'s 1 and 2 Shafts. Although their exact location is unknown due to their being filled in and covered decades ago (work at the No. 2 was suspended as early as 1858), their former presence can be estimated using historic maps and images. ${ }^{6}$ The No. 2 sat approximately 25 meters to the west of the Avery, with the No. 1 another 25 meters to the south. Beyond the No. 2, a 3.2 meter steam stack is all that remains of a probable engine house although its purpose is unknown (Fea.AV.319)

\footnotetext{
${ }^{4}$ Lake Superior Miner. 10 May, 1856; "Report of the President and Directors of the Pittsburgh and Boston Mining Company," printed in Mining Gazette. 23 May, 1863.

${ }^{5}$ Mining Gazette. 28 May, 1864. Falling rock from the bluff was a real but uncommon threat at the mine. According to the Gazette, a young girl was killed when "a rock broke away from the side of the bluff, came down, and smashed a house to pieces, killing [her] on the spot."

${ }^{6}$ Pittsburgh and Boston Mining Company. Report of the President and Directors of the Pittsburgh and Boston Mining Company. Pittsburgh: W.S. Haven, 1859.
} 


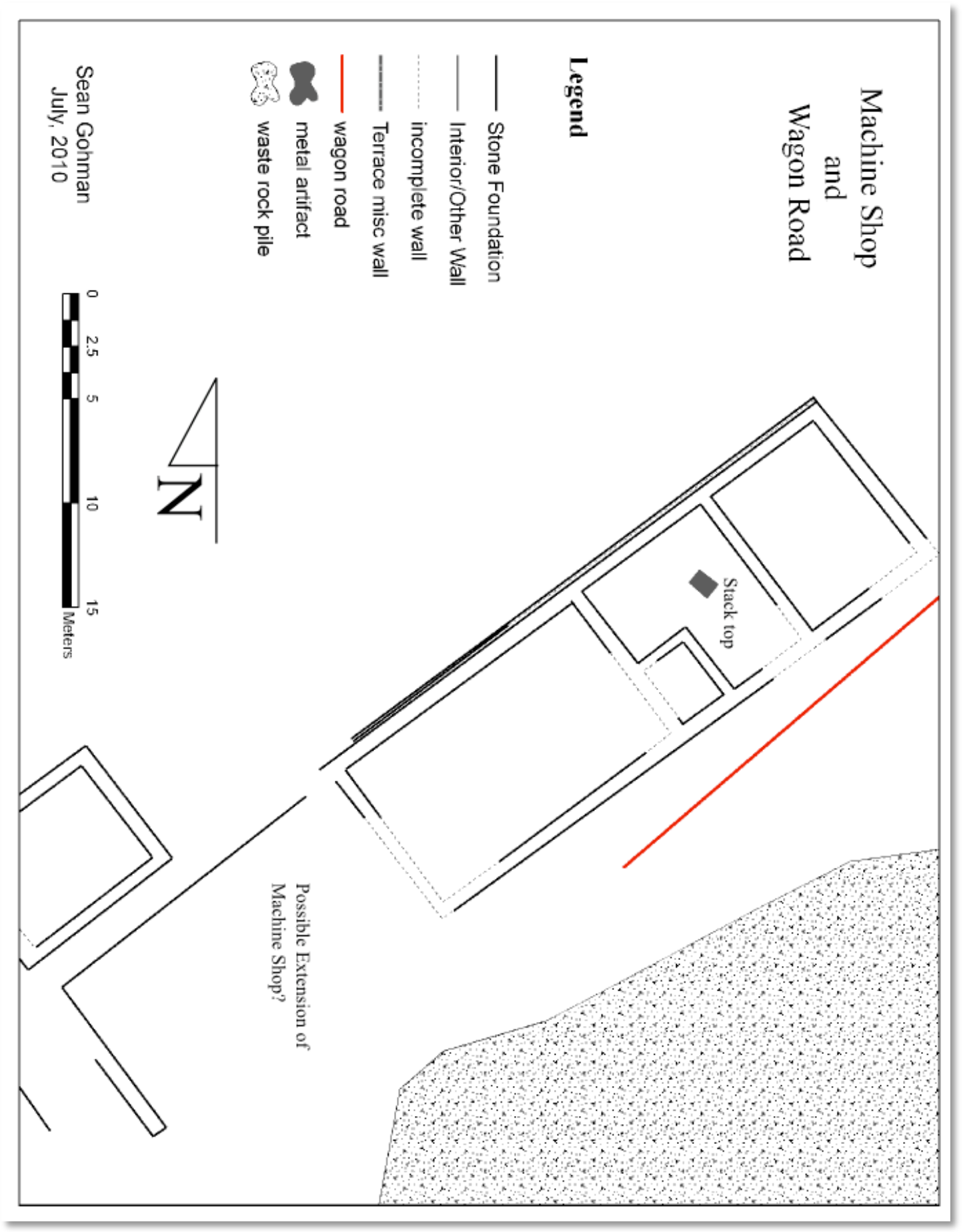

Fig. 3-11. (Image by Author). 


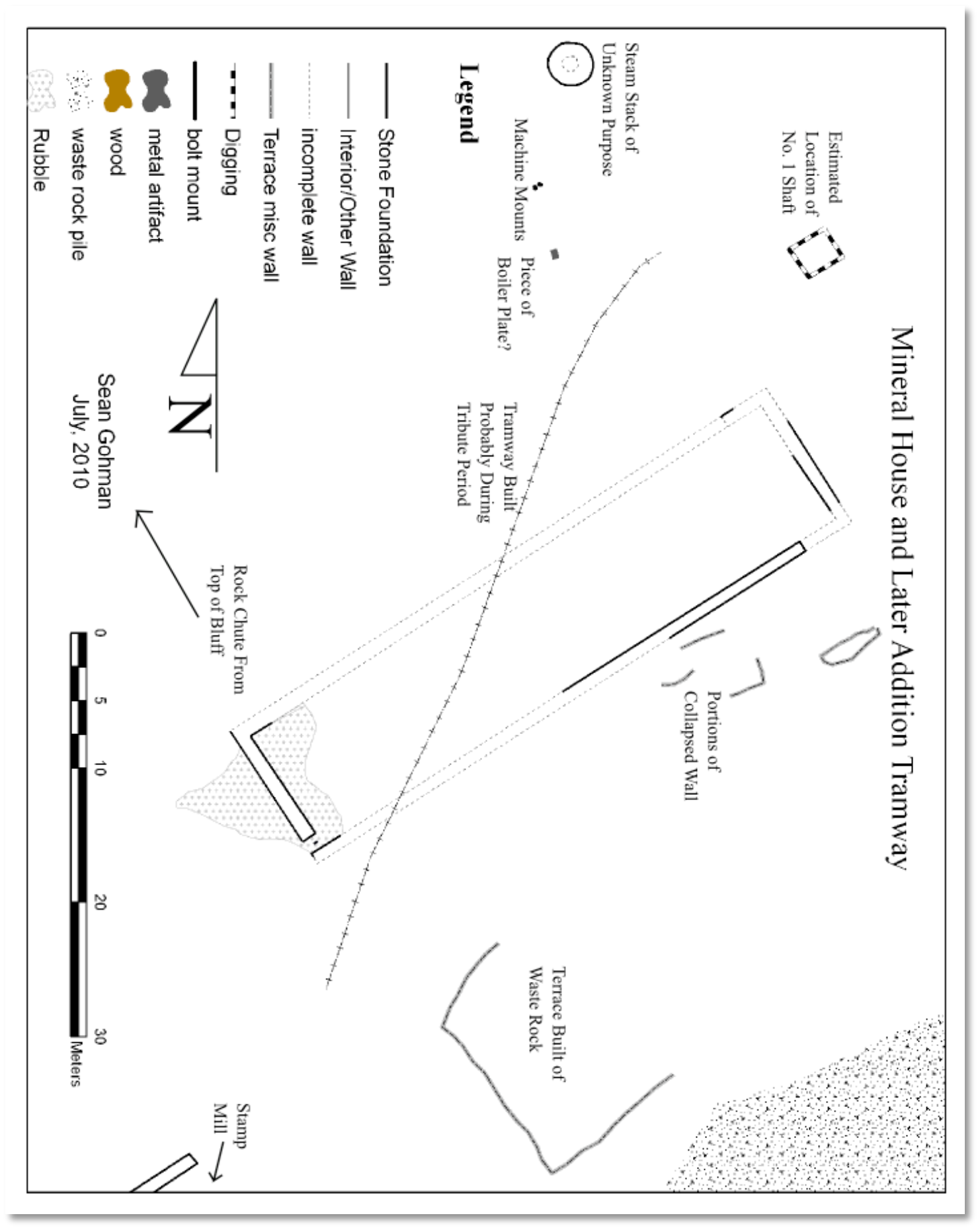

Fig. 3-12. (Image by Author). 


\section{Mineral Yard}

The mineral yard of a mid-nineteenth century copper mine is generally a multipurpose area consisting of enclosed warehouses and open-air structures (for roasting and rock breaking). In this way it acts as a pre and post-production area, and the Cliff Mine's mineral yard did just that. The yard sits at the base of the Greenstone Bluff, braced by the Avery Shaft engine/hoist house on the east and the stamp mill to the southwest. It the earliest years of the mine, this area was mainly used for roasting ore in order to facilitate its breaking for the stamps. Hand sorting also took place here in order to separate the barrel work from the waste rock and kiln work. In 1856 a stone mineral house, basically a large warehouse was built in this location measuring 44.9x11.5 meters (Fea.MY.200). ${ }^{7}$ Here, barrels and masses of copper were stored over the winter months during the suspended shipping season.

The remains of the mineral house at present consist of the eastern and western stone walls and fragments of the southern foundation wall (Fig. 3-12). The walls measured on average 1 meter in thickness around the entire structure but only the eastern and western ends of the structure survive. In historic images it can be seen that by the 1890's, this structure either collapsed or was torn down by the Cliff Copper Company or tributers, and portions of these collapsed walls can still be seen littering the ground to the south of the structure. In Fig. 1a stone arches near the top of the wall are visible. Apparently one of these archways fell in place and is still visible just to the south of the southern foundation wall.

Running NE/SW through the mineral house remains is a raised earthen mound (Fea.MY.203). This mound supported a tramway running from the Avery Shaft complex to the stamp mill and was likely constructed during the late nineteenth century. In fact, it is probable that the mineral house may have been demolished for the purposes of constructing and utilizing this tramway.

A stone terrace (Fea.MY.206) can be seen to the front and right of the mineral house. Using waste rock as material, the mine likely built up the natural features at the base of the bluff to create level working areas, possibly for kiln-roasting ore. During over

\footnotetext{
${ }^{7}$ Lake Superior Miner.10 May, 1856.
} 
the course of fieldwork, portions of this terracing were found to the SW of the mineral house continuing east. Unfortunately, vegetation prevented complete mapping of the eastern portion of the terracing.

\section{Stamp Mill}

The stamp mill of a copper mine is the second in the three step process of copper production, the first and third being extraction (mining) and refining (smelting). Initially, mills were simple structures housing water or powered gravity stamps, inefficient and prone to breakage, along with crude troughs and sieves to separate copper from rock. Over time, as steam equipment improved, stamp machinery became more powerful and washing equipment more efficient, allowing for the processing of higher quantities of rock each day. With higher production volumes came the need for larger accommodating structures. In the case of the Cliff Mine, this is precisely what happened as the mill grew from 7 stamp heads in 1846 to over 36 stamps and ore crushers by the mid 1860 's. ${ }^{8}$

The remains of the stamp mill (and its various features), washhouse, steam stack, wagon road, and inclined tramway were all mapped using the Total Station. Measured drawings, both profile and cross-section, were created of the mill as well.

The Cliff Mine's first stamp mill, built sometime in 1846, and housing a small steam engine, sat in approximately the same location as the larger 5-story mill complex built in 1851/52. ${ }^{9}$ Built of stone, this new building was damaged shortly after its construction in a fire, but was quickly repaired and its configuration can be seen in an 1857 photograph. The mill complex proper is divided into five distinct features: boiler room, a raised platform/foundation area, pass house, stamp room, and washhouse (Fig. 313).

The boiler room (Fea.SM.102), occupying the southwest corner of the complex, measures $11.7 \times 7.4$ meters. As with other engine/boiler rooms, what is present is the subfloor area, divided by a narrow, raised interior wall (Fig. 3-15). The walls are stone built, with the eastern southern wall showing signs of differing construction, possibly a later

\footnotetext{
${ }^{8}$ Pittsburgh and Boston Mining Company. Report of the President and Directors of the Pittsburgh and Boston Mining Company. Pittsburgh: W.S. Haven, 1847-1870.

${ }^{9}$ Lake Superior Journal. 29 Oct. 1851.
} 


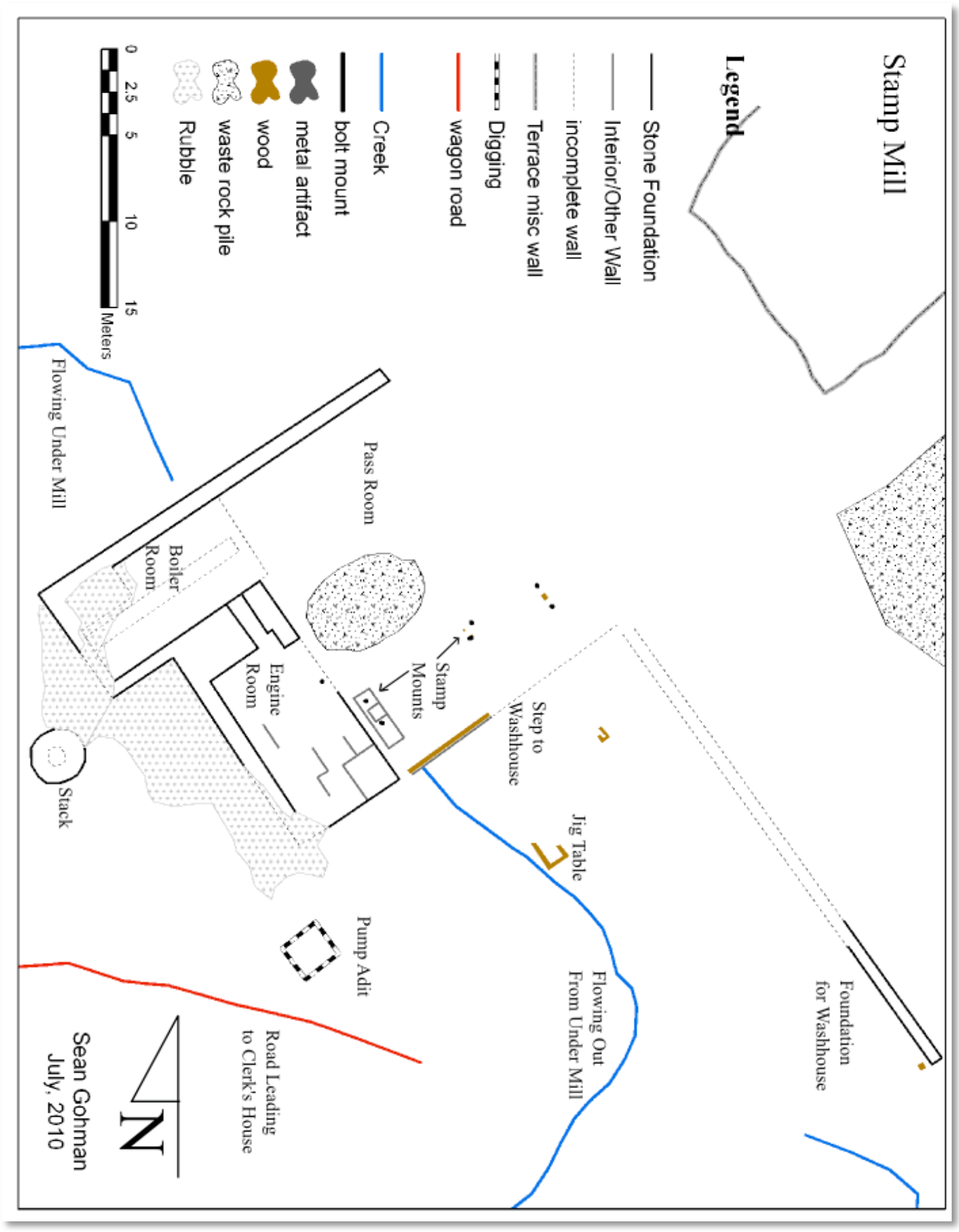

Fig. 3-13. (Image by Author). 


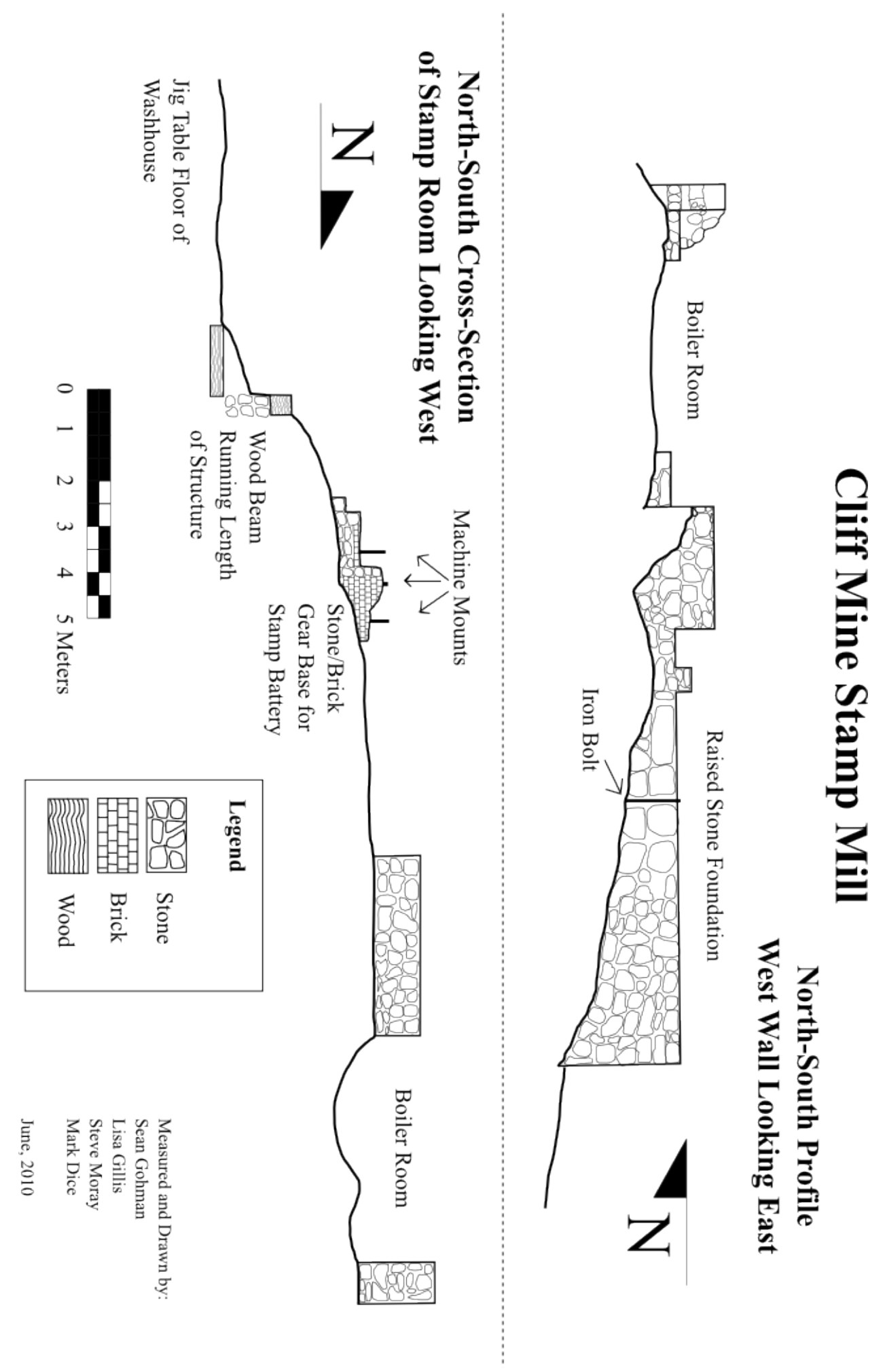

Fig. 3-14. (Image by Author). 


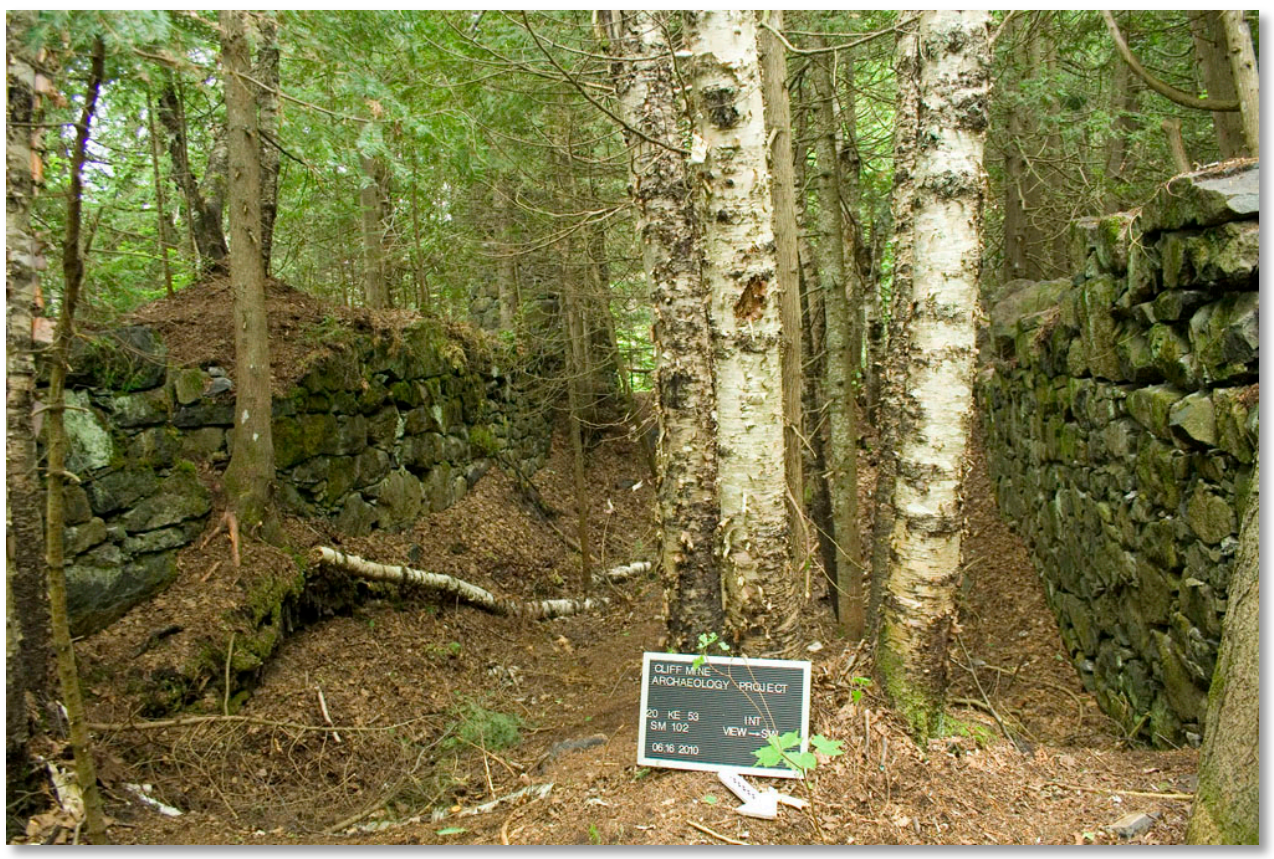

Fig. 3-15. Fea.SM.102. The stamp mill's boiler room, looking west from the pass room. The stamp batteries sat to the left of the picture. (Image by S. Moray).

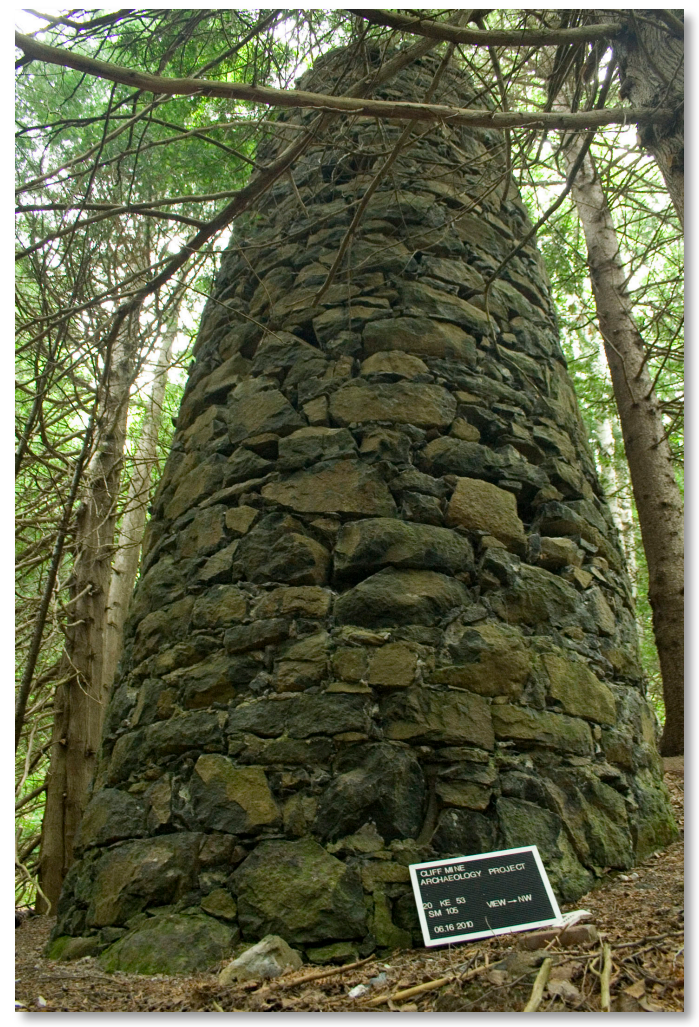

Fig. 3-16. Fea.SM.105. The stamp mill's 3.2 meter diamter smoke stack, from the east. (Image by $S$. Moray). 
addition or repair work after the fire. West of the boiler room is its associated smoke stack (Fea.SM.105. Fig. 3-16). Measuring 3.2 meters in diameter, this stack provided an outlet for the exhaust gases created by burning wood and coal in the boilers.

A raised platform (Fea.SM.104) is connected to the boiler room to the south, and may be the location of the vertical beam engine built by Nicholas Vivian and installed in 1851. ${ }^{10}$ From this platform (Figs. 3-17), the engine powered both the stamp machinery and pumping equipment situated over an adit 5 meters south of the feature. The platform area measured $14 \times 7$ meters and as seen in historic photographs, was the foundation of many different buildings over the years, including a later nineteenth century adaptive reuse of the mill by the Tamarack Mining Company. Found on the surface of this feature were three iron bolts, machine mounts that connected to the gearing that operated the stamp equipment.

To the east of the raised platform are the pass and stamp rooms. The pass room (Fea.SM.103) was where rock was dumped before being fed to the stamps via hoppers. Though is has roughly the same footprint as that of the boiler room, the pass room did not have a sub-floor, and therefore sits 1.5 meters higher than its neighbor. Between the pass and stamp rooms sits a pile of earth and stone, likely one of the last accumulations of rock awaiting stamping during the Tamarack period.

The stamp room (Fea.SM.100) measures 14 meters SW/NE but its width is unknown due to its eastern wall not being visible at the surface. The only indication as to the features width are three sets of mounts, equally spaced apart, that designate the locations of three batteries of stamps. It is known that at one time the mill housed 36 stamps, and therefore must have been quite large. However, the arrangement of the stamps is not found in written documents, so this cannot be used to approximate size. Historical photographs are available showing the layout of the structure, and indicate a width of roughly 20 meters. Within this room are the remains of a stone and brick pedestal that housed gearing which transmitted power from the engine to the camshaft (which rose and lowered the stamps). While the pedestal, gearing, and stamp machinery attached are only seen in photographs associated with the Tamarack period, it is a

\footnotetext{
${ }^{10}$ Ibid.
} 
reasonable assumption that the layout of the equipment would not have changed much over 30 plus years (Fig. 3-18).

The remains of the washhouse, lying below and to the southeast of the stamp room, measure $31.3 \times 16$ meters. Originally built in 1856 with dimensions of 100x50 feet, a later 50-foot addition was constructed in 1863 though no evidence of this addition can be seen at the surface. ${ }^{11}$ A stone foundation (Fea.SM.101 supported a wood frame structure that housed 4 (and possibly 12) Asmus' automated jigging tables used to aid in the separation of copper from stamped rock. The washhouse is separated from the stamp room by a 1.7-meter step, built of stone and topped with a very large squared timber (Fea.SM.110). The washhouse is situated this way, below the stamp room, in order for gravity to ease and assist in washing copper. Found 6.5 meters southeast from the step, the wood frame of a jig table is still present, partly buried under earth and stamp sand (Fea,SM.108).

The other features located within this operational zone are associated with transportation, a wagon road and inclined tramway. The 3.3 meter wide wagon road (Fea.WP.711) ${ }^{12}$ begins south of the mill complex and continues west for 250 meters along the base of the bluff, stopping at the Clerk's House, a stone foundation dwelling not associated with the industrial core of the site. The inclined tramway (Fea.SM.109), linking the No. 3 surface plant at the top of the bluff with the mill below, is only identifiable by a depression running a third of the distance up the bluff, and was mapped with the Total Station as far as it was possible to follow.

\footnotetext{
${ }^{11}$ Lake Superior Miner. 10 May, 1856; "Report of the President and Directors of the Pittsburgh and Boston Mining Company," printed in Mining Gazette. 23 May, 1863.

${ }^{12}$ Originally placed within the WP peripheral zone, the wagon road's feature number has been retained for continuity.
} 


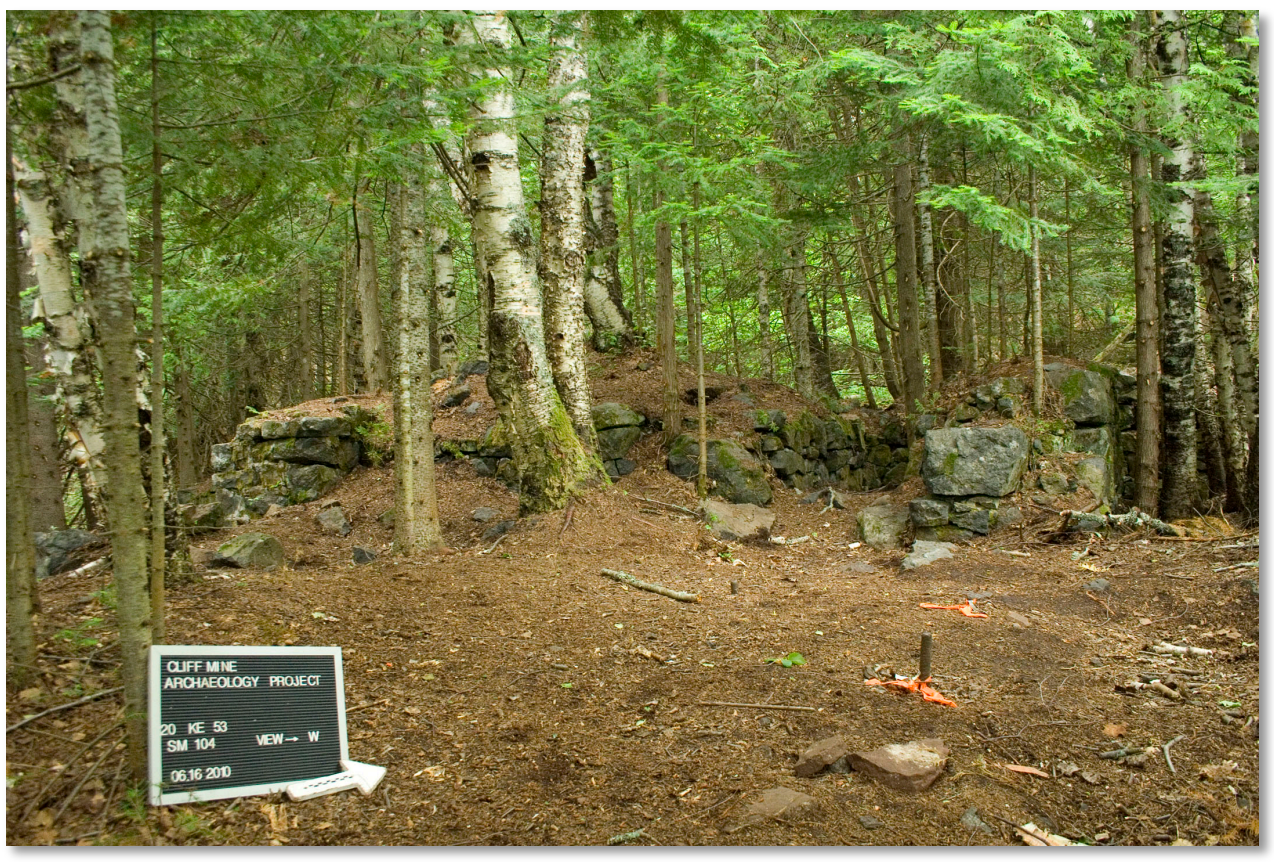

Fig. 3-17. Fea.SM.104. The stamp mill's raised platform, from the south. Possible location for a steam engine. The stamp batteries sat to the right of the picture. (Image by S. Moray).

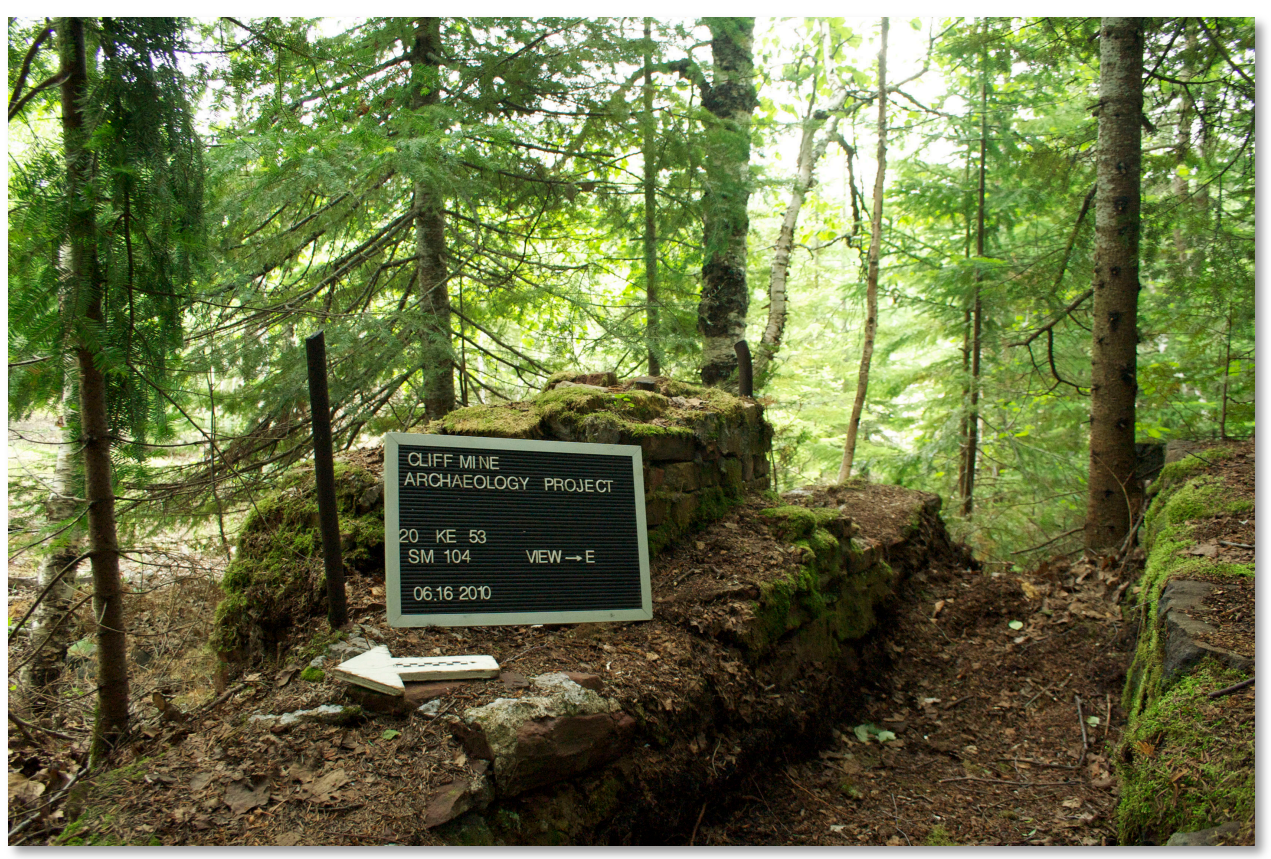

Fig. 3-18. Fea.SM.104. A stone and brikc pedestal with machine mounts that held gearing for the cam shaft and stamp batteries. (Image by S. Moray). 


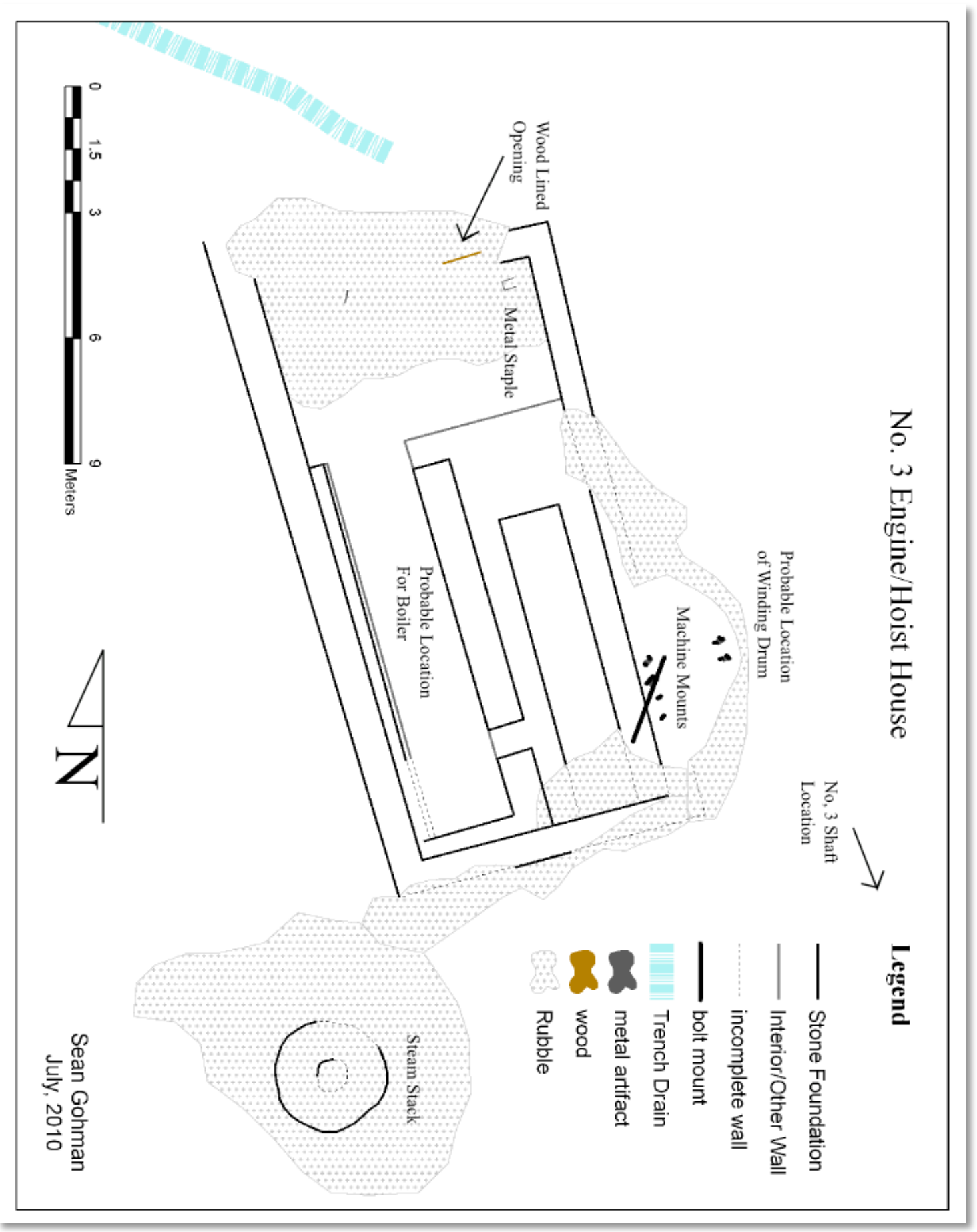

Fig. 3.19. (Image by Author). 


\section{No. 3 Shaft Surface Plant}

Measured drawings and digital remains of the operational zone occurred over two days, as only one structure was identified requiring detailed examination, an engine/hoist house. Other features included in this operational zone are a shaft, waste rock, a trench, and Calumet \& Hecla era concrete blocks.

The No. 3 engine/hoist house's construction began in late 1853 as part of the Cliff Mine's plan to alleviate ventilation problems in the underground workers caused by the No.'s 1 and 2 Shaft's close proximity to each other. ${ }^{13}$ Shaft No. 3 penetrated the top of the Greenstone Bluff on the vein to meet with Level 1, with intentions to use it as a way to raise and dispose of waste rock. The structure housed one steam winding engine and likely, one steam boiler.

The remains of the structure are in relatively good condition, since the location was effectively abandoned after the P\&BMC sold the property in 1871 . The structure measures 14.6x7.5 meters, and is constructed of stone (Fea.N3.400. Fig. 3-19). The eastern, western, and southern foundations are still present and in stable condition. The northern foundation is no longer present but this may be architecturally intentional. Unfortunately, there are few photographs of the No. 3 surface plant and those that exist show only the roofline of the structure.

The foundation remains, the majority of which are below the surface of current grade topography, detail the subfloor of the structure. The wide berth on the western interior of the structure is the probable location of the steam boiler, with its proximity to a 2.6-meter diameter smoke stack supporting this notion. The eastern half of the structure's interior includes a raised platform with two pedestal walls that would have supported the main floor (Fig. 3-20). Here the winding engine likely sat, driving a drum situated within a cluster of iron machine mounts situated just inside the eastern foundation wall (Fig. 321). The drum wound and unwound a wire rope that descended into the No. 3 Shaft lying 19 meters to the SE of these mounts.

The shaft itself is on a slope just below the top of the bluff (Fea.N3.402. Fig. 322). It measures approximately 3 meters across (it was deemed too dangerous to take

\footnotetext{
${ }^{13}$ J.D. Whitney, The Metallic Wealth of the United States: Described and Compared with that of Other Countries. (Philadelphia: Lippincott, Grambo \& Co., 1854), p.277.
} 
accurate measurements) and is now filled in with timbers, earth, and waste rock. Emerging from its southern side is an iron pipe, most likely used for pumping water. To the east, approximately 25 meters, are a grouping of three concrete blocks affixed to the bluff's edge. Each block also has a pair of iron rods embedded within them, and corresponding tie rods located further up the bluff. These blocks may have supported power lines that stretched from below, providing electric power to the Calumet \& Hecla workings at the No. 4 (Howe) Shaft in the 1920's and '30's.

Extending NW from the northern end of the engine/hoist house, a trench (1.5 meters wide) continues for over 35 meters (Fea.N3.405). During the mapping of the structure, a wood lined opening was discovered in the northern wall of the structure that lined up with this trench, and it likely provided water to the engine/hoist house for its steam boilers. 


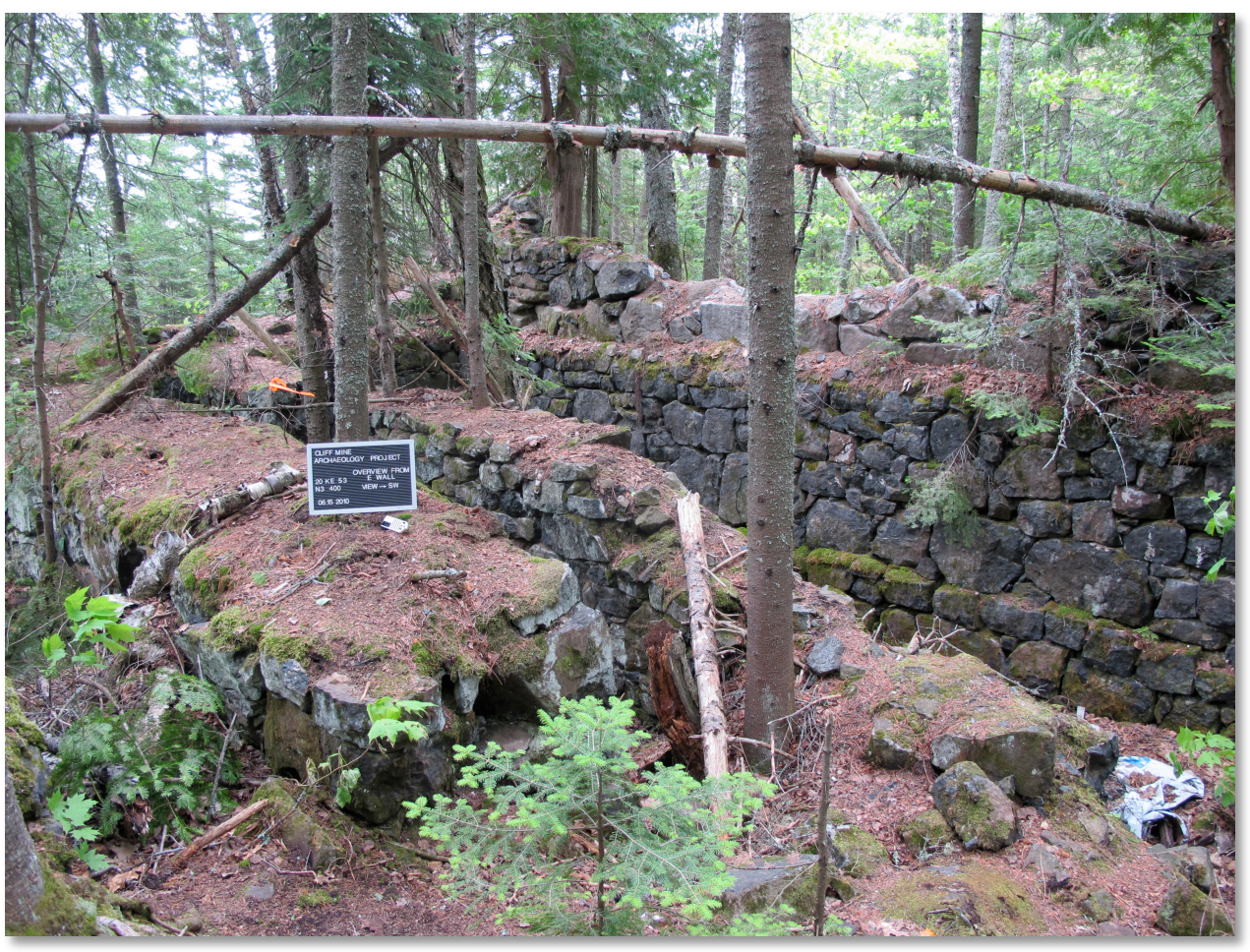

Fig. 3-20. Fea.N3.400. The No. 3 Engine/Hoist House looking south. The engine likely sat atop the pedestal wall on the left while the boiler occupied the wide gap on the right. (Image by S. Moray)

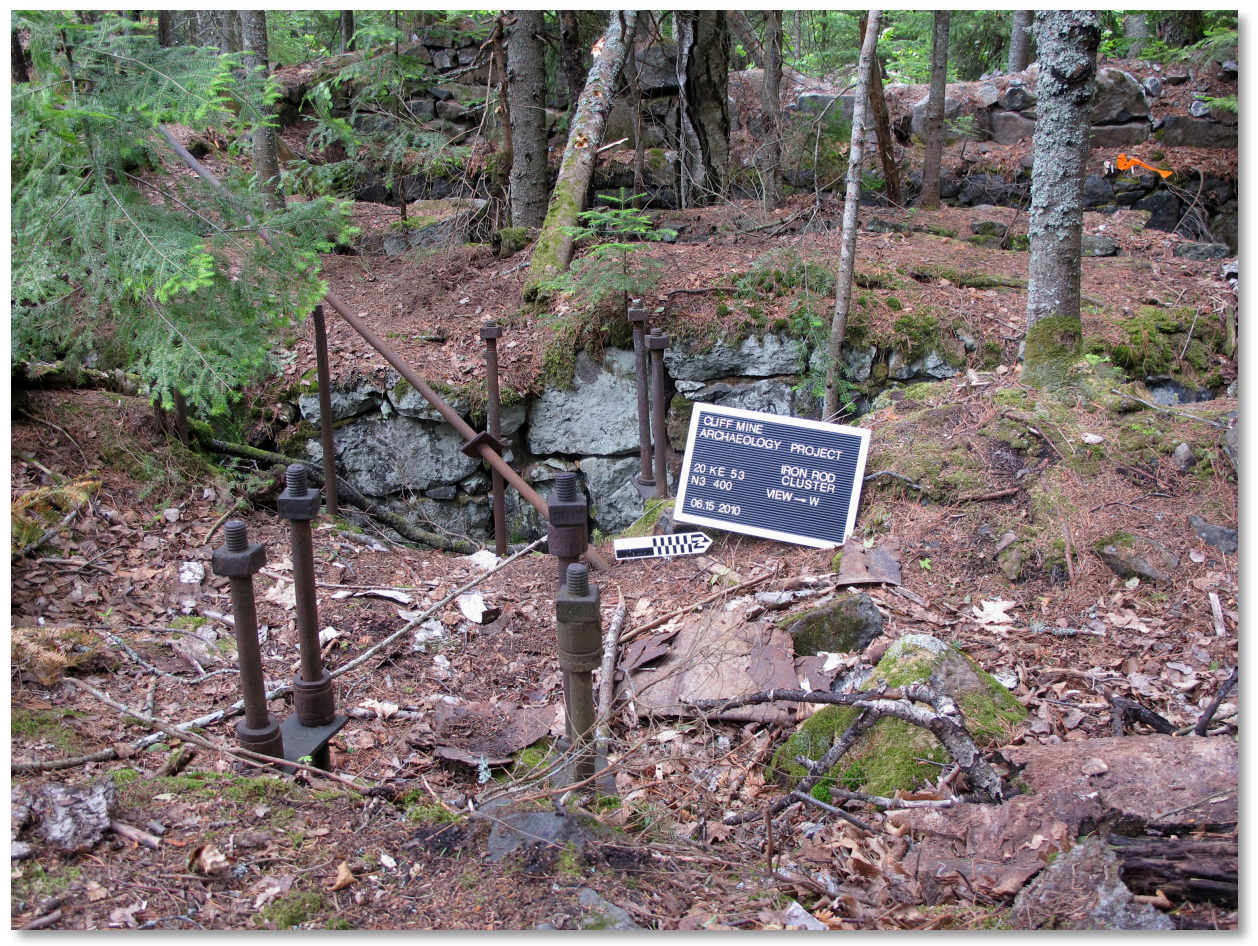

Fig. 3-21. Fea.N3.400. The probable machine mounts for the hoist/winding drum. (Image by S. Moray). 


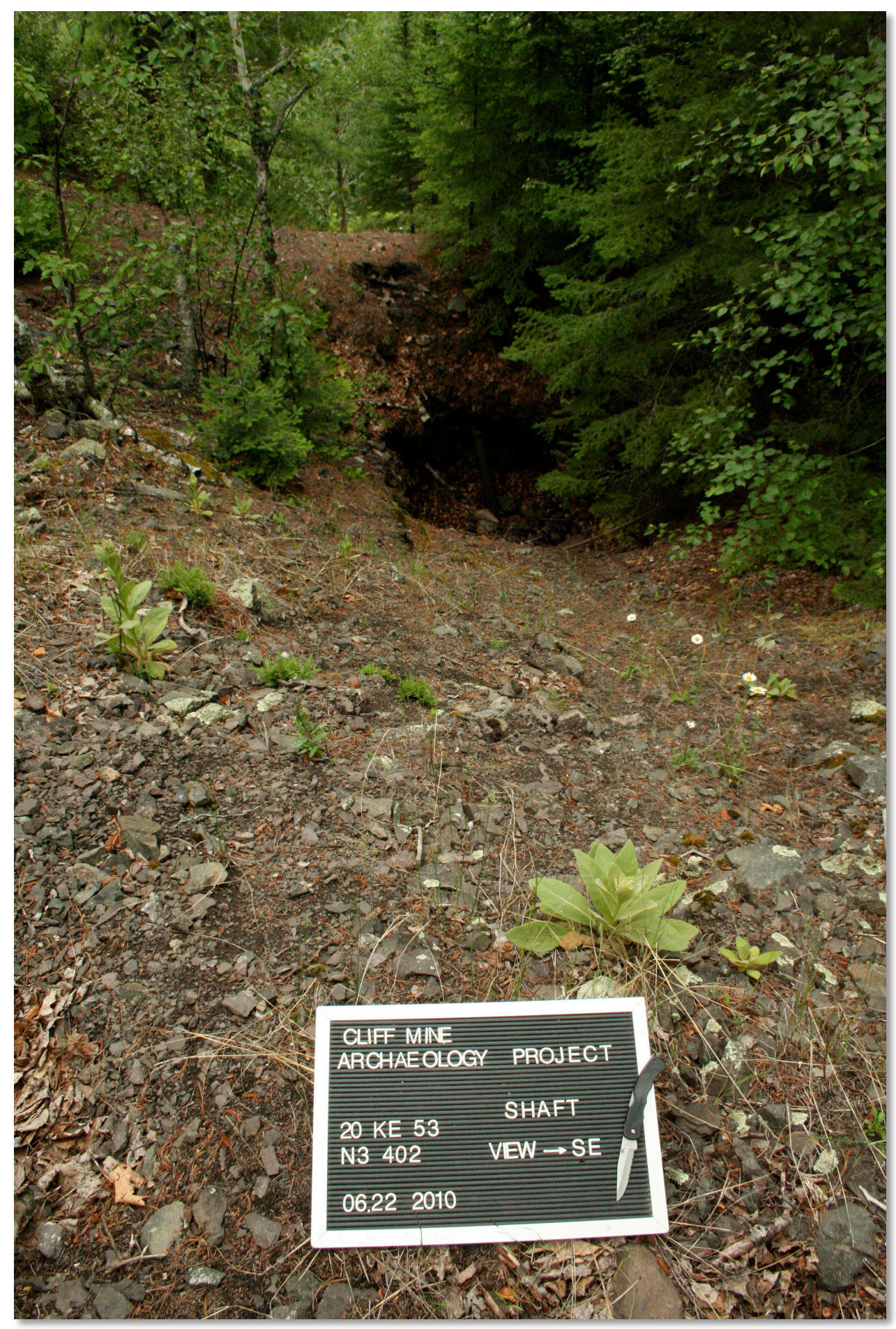

Fig. 3-22. Fea.N3.402. The No. 3 Shaft, from the northwest. Pipe used for pumping water from the mine is still present exiting the shaft. (Image by S. Moray). 


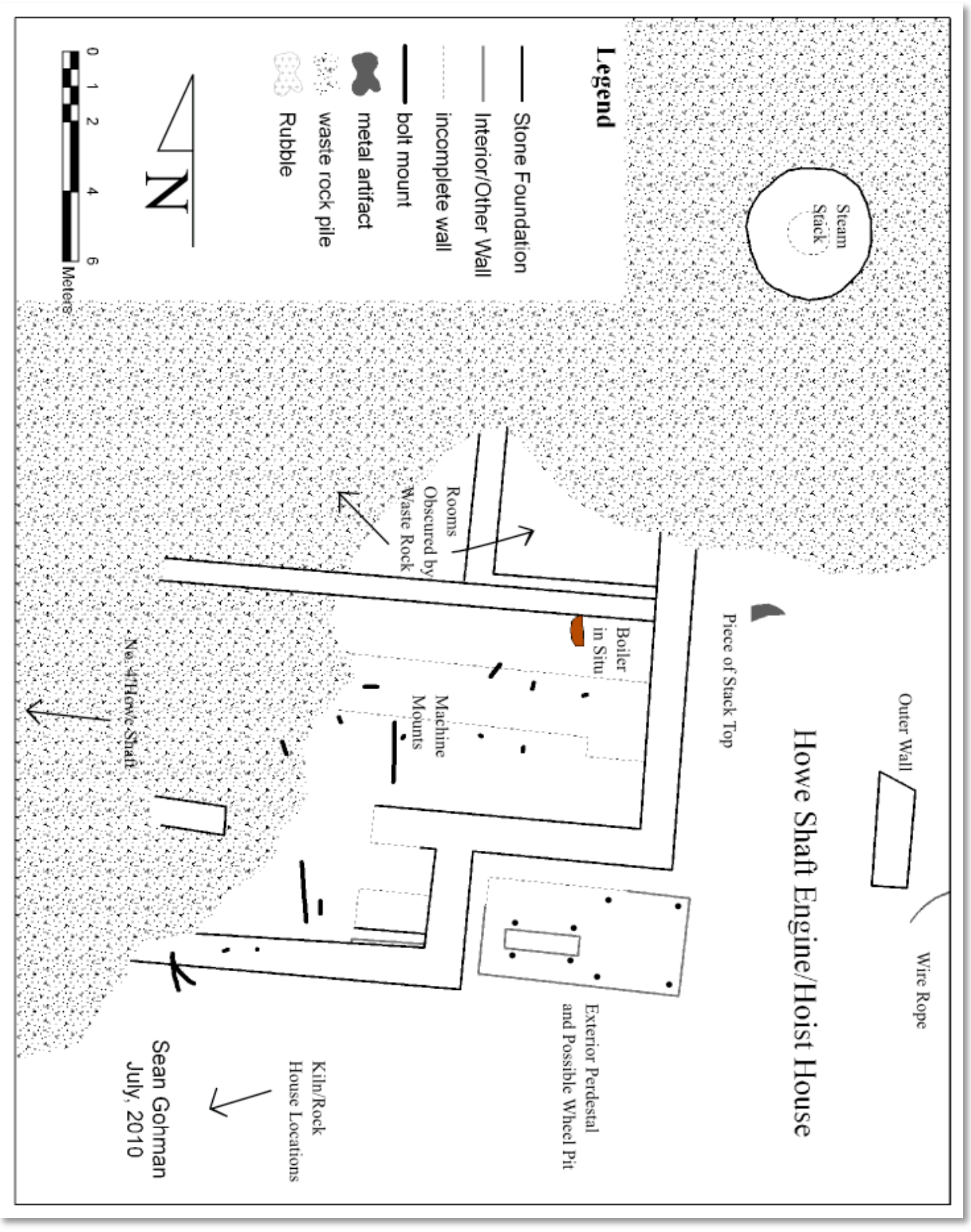

Fig. 3-23. (Image by Author). 


\section{Howe Shaft Surface Plant}

This operational zone covered the largest area of the industrial core zones, roughly 8 acres. Due to its size and scale, measured drawings of this zone's features focused primarily on the engine/hoist and kiln/rock houses, with the rock piles and later period features only receiving attention with the Total Station mapping equipment. Later in the field season, time allowed for the identification of the remains of a covered tramway that began at a kiln/rock house and terminated at the edge of the bluff. The identification and mapping of this feature provided an exciting end to the field season, as it links the Howe Shaft surface workings to the stamp mill and surface workings at the base of the bluff, 1000 meters to the south.

The No. 4 (Howe) Shaft surface plant was begun in 1859, as part of the Cliff Mine's plan to move principal mining operations northward to follow the vein. Finished in 1860, it included an engine/hoist house complex, a smoke stack, and kiln, shaft, and rock houses, all (save the shaft house) built of stone. The kiln and rock houses were where rock was roasted and sorted to separate copper out from the waste rock and stamp work. The engine/hoist complex housed two engines, one at least being a vertical beam rotative engine (Figs. 3-23) used to power the hoist machinery.

The structure (Fea.N4.500), half buried in waste rock dumped by the Calumet $\&$ Hecla Mining Company in the 1920's and '30's, measures roughly 22x17 meters (Fig. 324). Much like the No. 3 and Avery engine/hoist houses, the remaining stone walls only indicate the lower story of the structure, with spaces in the walls for timber floor supports still visible. The northern and eastern sections of the structure, where the vertical beam rotative engine sat, are partially buried and their exact size and layout can only be estimated using historic photographs. An associated 3.7 meter diameter smoke stack (Fea.N4.501) is located just to the NE of the structure, its base also buried in waste rock (Fig. 3-25). Of note is a large stone near the top of the stack that appears to be carved with the year " 1860 ," the only instance of date stamping found during the field season. 8 meters to the south of the stack a section of the stack's metal top was also found (Fig. 326). 


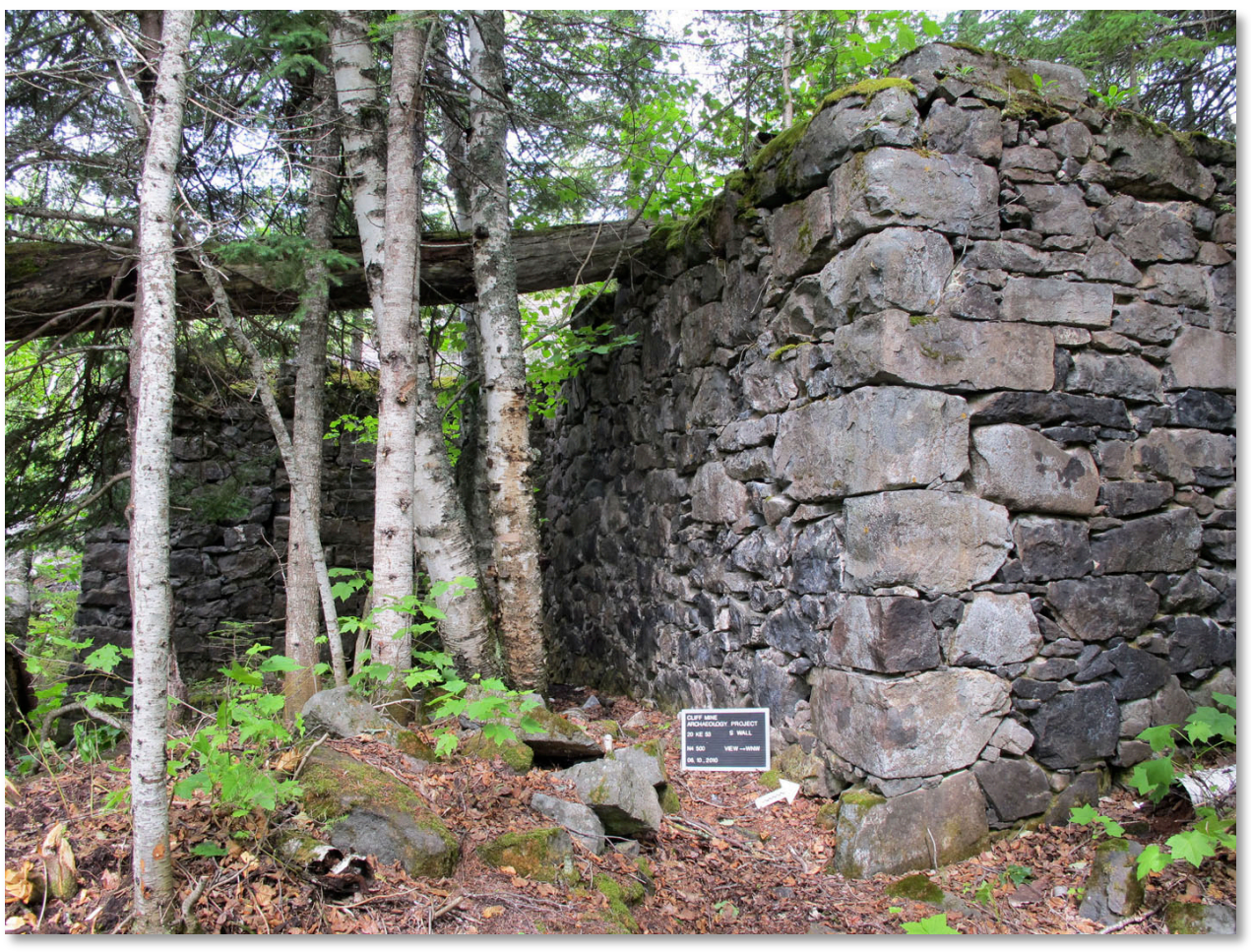

Fig. 3-24. Fea.N4.500. Howe engine/hoist house exterior wall, from the southwest. (Image by J. Baeten).

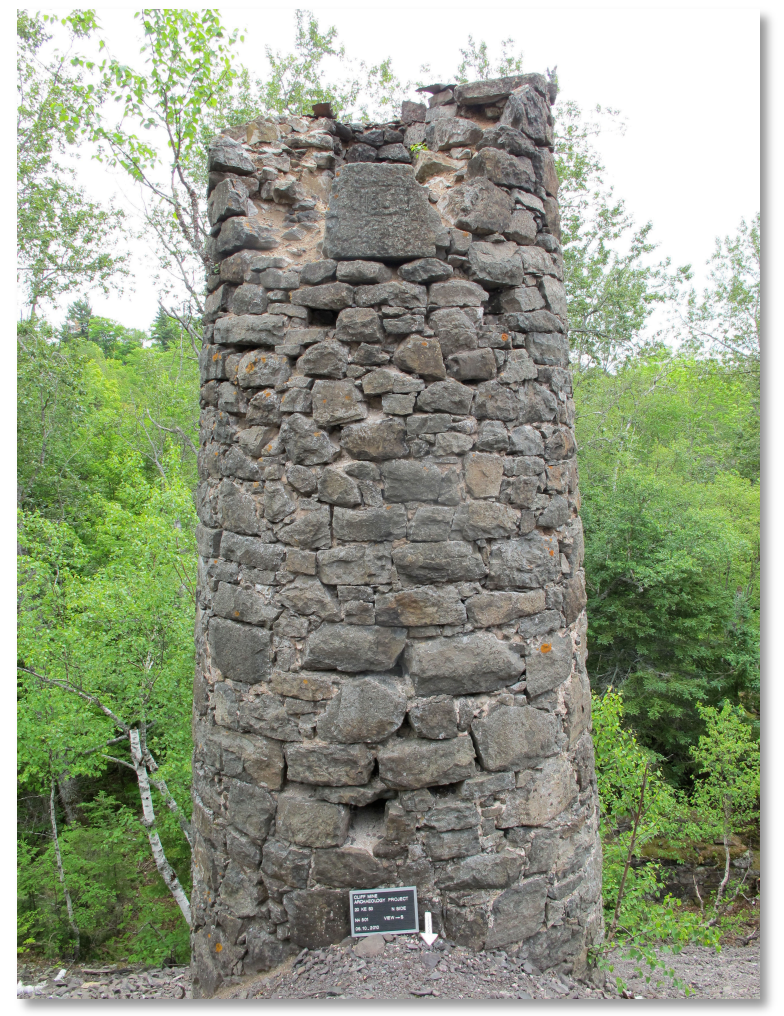

Figs. 3-25 \& 3-26.

Fea.N4.501. Left: Howe

Shaft's $3.7 \mathrm{~m}$ diameter smoke stack, the largest at the site, from the north. Below: Detail of date stamp on stack,

"1860?" (Image by J. Baeten)

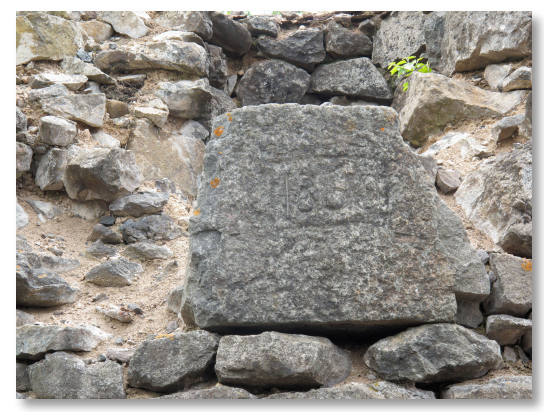




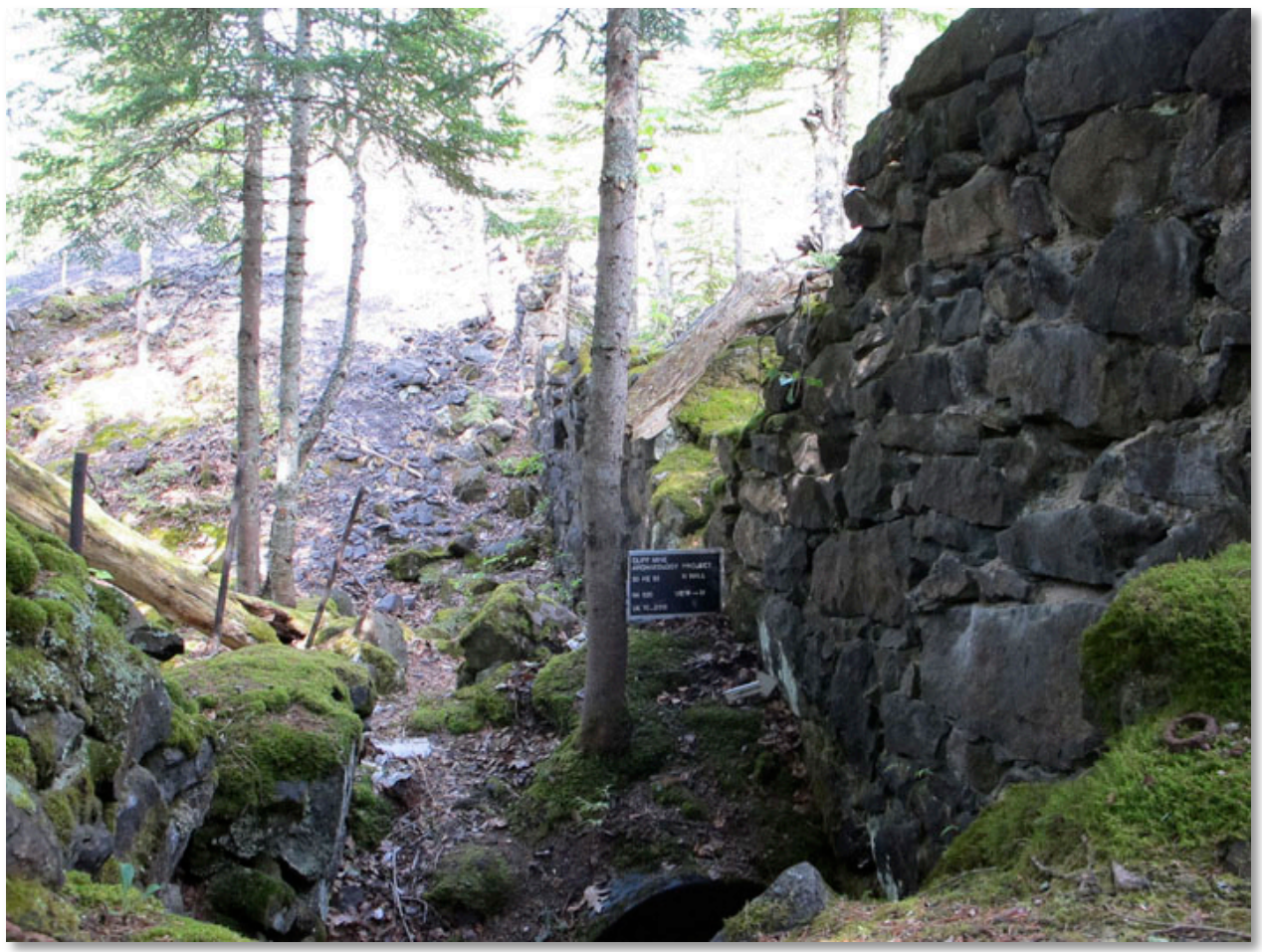

Fig. 3-27. Fea.N4.500. Boiler room of the Howe engine/hoist house, from the south. Remains of in situ boiler can be seen at bottom center. (Image by J. Baeten).

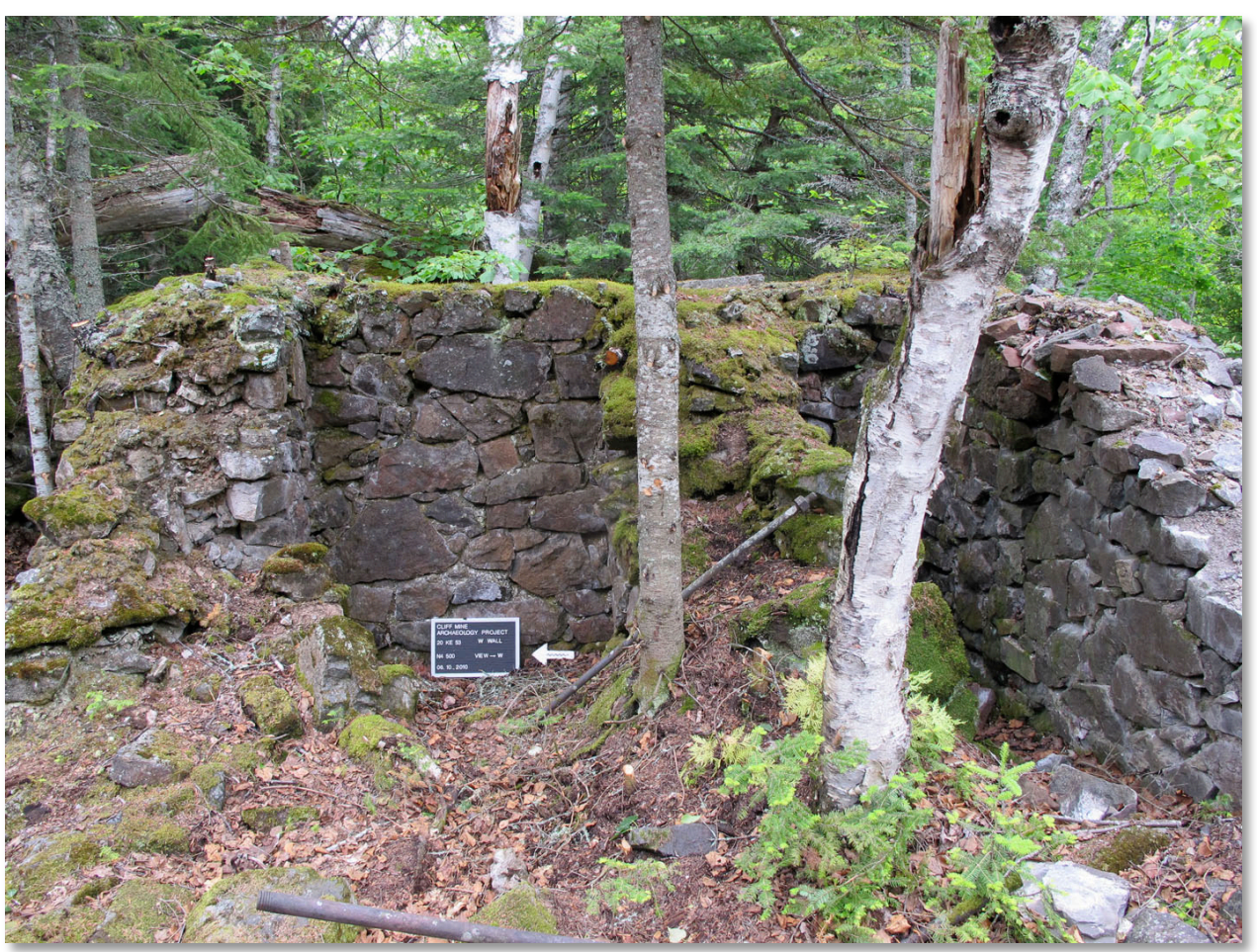

Fig. 3-28. Fea.N4.500. Probable location of the winding drum for the Howe Shaft, from the north. (Image J. Baeten). 
Within the engine/hoist structure itself are the remains of a boiler, apparently in situ, lying under a collapsed stone wall. The boiler artifact is located within the northern half of the likely boiler room, which is divided by a collapsed interior wall. Bracing this interior wall are a series of iron bolts, some over 6 meters in height, which may have helped support the large hoisting engine (Fig. 3-27). To the south of this boiler room area, another smaller room with iron bolts is situated (Fig. 3-28). This is the possible location of a second steam engine, once used by the North American Mining Company and brought over to the Howe shaft in 1863 in order to assist in the raising duties at the shaft. ${ }^{14}$ Mass copper was coming out of the Howe shaft instead of the Avery due to the northward movement of mine work, and it was decided two engines were required to handle the load. They dedicated the original engine to the running of the skips, while the new engine handled the mass copper. ${ }^{15}$ Due to a change in construction evident in the exterior walls on the western side of the structure, it's possible that this area was an addition to the structure, built to house the new engine.

Outside, but attached to, the structure to the $\mathrm{SW}$ is a small platform, $5.5 \times 2.5$ meters, with two groupings of 4 iron bolts. Historic photographs are inconclusive as to the purpose of this feature, but a curved depression, possibly a wheel pit, may indicate the former presence of a small, portable steam engine. According to the mine's annual report of 1859, a portable engine was purchased for the Howe Shaft surface plant but its intended purpose was not given. ${ }^{16}$ Another 6 meters to the east, a stone pedestal, 1.5 meters high and 4 meters long, is evidence to an exterior wall separate from the engine/hoist house proper.

The dimensions of the kiln and rock house (Fea.N4.503) remains are $20.4 \times 11.9$ meters and consist of two large stone walls (north and east), a level interior surface (where rock may have been roasted, broken, or stored), and two stone wall fragments

\footnotetext{
${ }^{14}$ Philip P. Mason, ed., Copper Country Journal: The Diary of Schoolmaster Henry Hobar, 1863-1864. (Detroit: Wayne State Press, 1991), p.154.

${ }^{15}$ Pittsburgh and Boston Mining Company. Report of the President and Directors of the Pittsburgh and Boston Mining Company. Pittsburgh: W.S. Haven, 1864. p.16.

${ }^{16}$ Pittsburgh and Boston Mining Company. Report of the President and Directors of the Pittsburgh and Boston Mining Company. Pittsburgh: W.S. Haven, 1859. p.5
} 
found buried in waste rock. The large stone walls are over two meters in height at present and were nearly twice as high during use (Fig. 3-29).

Much of the operational zone is covered in waste rock from the P\&BMC's and C\&H periods of operation (Fea.N4.505). All of the rock removed from the Howe Shaft (that wasn't veinstone or mass copper) wound up here, at the end of a tramway. The landscape today looks much like a hand, with each finger a different tramway and waste pile. At the "palm" of the waste rock hand, two concrete foundations, built by $\mathrm{C} \& \mathrm{H}$ in the 1920's, still stand. Dotted with iron bolts, these two concrete pedestals likely housed electric hoisting equipment for their explorations of the shaft.

The shaft itself is located under a logging road that bisects the surface workings, $50+$ meters north of the engine/hoist house. Covered and capped by C\&H, wood beams now litter the sides of the logging road, attesting to the shaft house that once stood there. Beyond the shaft to the north is another C\&H era concrete foundation (Fea.N4.509), and the remains of a stone powder house (Fea.N4.507).

During the Howe Shaft's first period of use, a covered tramway (Fea,N4.506) led from the kiln/rock house 350 meters to the south to the edge of the bluff, where its identifiable terminus met with an inclined rock chute (Fea.MY.208). During the final week of the field season, partial remains of this tramway were uncovered during a pedestrian survey of the area. An historic map from the late nineteenth century indicated the tramway's location, but the vegetation and terrain of the area currently made its identification difficult. Initially a flat, inclined pathway leading west from the logging road was believed to be the tramway (Fea.N3.408). After mapping with the Total Station it became evident this could not be the tramway, as its orientation didn't line up with either the kiln/rock house or the tramway's known terminus at the edge of the bluff.

Clearing brush and following the tramway's terminus north, a level pathway, 4 meters in width, was documented for approximately 150 meters before coming up against a large waste rock pile. Along the eastern side of the rock pile a course of stone continued into a depression made by two rock piles. After mapping with the Total Station GIS equipment, it is believed that this course of stone is part of the tramway and that the covered tramway ran between these two rock piles to its starting point, the kiln/rock 
house. A tramway spur was also discovered while mapping the tramway near the edge of the bluff. This spur may be associated with the inclined tram that connected the No. 3 surface plant with the mine's stamp mill, located at the base of the bluff.

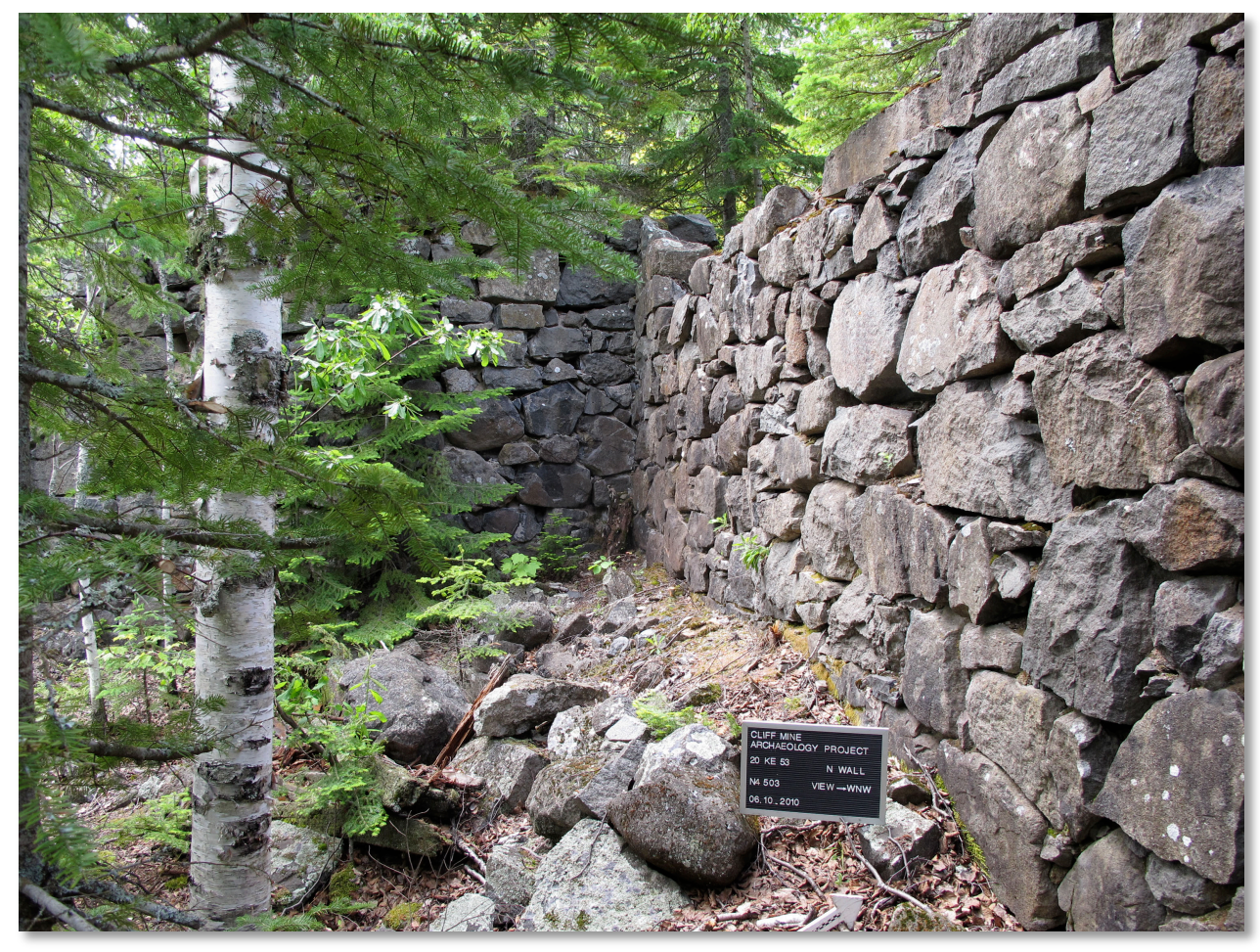

Fig. 3-29. Fea.N4.503. NE corner of the kiln/rock house located NW of the Howe Shaft engine/hoist house. (Image by $\mathrm{J}$. Baeten). 


\section{Peripheral Operational Zones Including Town Site of Clifton}

Peripheral areas include features located on or near wagon roads leading east and west from the industrial core, as well as the 50 hectare townsite of Clifton. Three weeks of the field season were dedicated to documenting these peripheral areas, however only a limited number of features were found to be directly related to the industrial core and its technical systems. Therefore, digital mapping with the Total Station was limited to only the eastern and western wagon roads and various landscape features lying near the west branch of the Eagle River.

The eastern and western peripheries along the wagon roads each contained exploration diggings and at least one trench. It is noted in the P\&BMC's Annual Report that exploratory work took place 800 feet to the east of the Cliff Vein, the exact location of the trench found on the eastern wagon road (Fea.EP.806). ${ }^{17}$ To the west, another trench (Fea.WP.705) was found and could correspond to diggings shown on an historic map dated from 1862 and drawn by then mine superintendent, James Watson. Also found and documented on the western periphery was a two-room stone structure (Fea.WP.704) 15 meters to the west of the exploratory trench. Although not mentioned in any known historical records, this building may have been associated with the nearby diggings, as its configuration does not lend itself to a dwelling.

Along the west branch of the Eagle River, large waste rock piles create a dividing line between the townsite of Clifton and the industrial core. To the south of these rock piles are the former locations of the carpentry shop, schoolhouse, and mine office. Although no evidence remains of these structures on the surface, historic photographs and maps provide accurate locations for possible future examinations. No measured drawings of this area took place, and only the rock piles and river course received attention from the Total Station mapping equipment.

Over 100 distinct features were documented during the three-week pedestrian survey of the Clifton townsite. Many were small earth and stone foundations, the remains of log constructed laborer's dwellings, such as those in Fig. A-23. Six separate episodes of building worker's housing were undertaken at the Cliff: 1848 (25 buildings erected,

\footnotetext{
${ }^{17}$ Pittsburgh and Boston Mining Company. Report of the President and Directors of the Pittsburgh and Boston Mining Company. Pittsburgh: W.S. Haven, 1870. p.8.
} 
worker's housing included), '55 (“10 dwelling houses"), 58 (“5 dwellings to house 10 families"), '63 (30 log homes), '64 (“10 log houses and 1 frame house”), '65 (“2 frame houses"). ${ }^{18}$ Some of these homes were built near the Howe Shaft surface plant for the workers based there, but the majority of these dwellings were located south of the west branch of the Eagle River.

Three churches, Methodist (Fea.CT.918), Episcopal (Fea.CT.988), and Catholic (along with associated cemetery) (Fea.CT.988) were also located within Clifton, and each of their foundations were documented. Other large features included a the remains of a stone warehouse (Fea.CT.986), the mine superintendent's home (Fea.CT.985), an icehouse (Fea.CT.923), and the various roads and paths connecting the community's structures to each other. Cutting through the townsite SW-NE was also the railroad grade of the Keweenaw Central Rail Road. As it was not present during the mine's initial period of operation, the KCRR grade was not documented by the field crew.

During the 1850's, the North American Mining Company sank two shafts in the southwestern portion of the townsite, and worked at this location until selling their property to the P\&BMC in $1860 .{ }^{19}$ The shafts, termed South Cliff No.'s 1 and 2, were worked intermittently under the tribute system. From that point on into the 1910's, these workings (and three additional shafts) were the site of exploration work more than profitable mining. The remains of the South Cliff No.'s 1 and 2 surface plants are at present ephemeral, their rock piles being the only evidence found at the surface. To the south, approximately 125 meters from the South Cliff No. 2, the stone foundations of an engine house (Fea.CT.999) and steam stack (Fea.CT.996) were found during the last week of the field season. Continuing south, other features, such as an iron pipe emerging from the ground and a large rock pile only 200 meters from the M41 highway, indicate the locations of the No.'s 3, 4, and 5 Shafts as well.

\footnotetext{
${ }^{18}$ Pittsburgh and Boston Mining Company. Report of the President and Directors of the Pittsburgh and Boston Mining Company. Pittsburgh: W.S. Haven, 1849-1866.

${ }^{19}$ Charles E. Wright, Annual Report of the Commissioner of Mineral Statistics of the State of Michigan, for 1880 (Lansing: W.S. George \& Co. , 1881), p.23-24.
} 


\section{Chapter 4:}

\section{Conclusions}

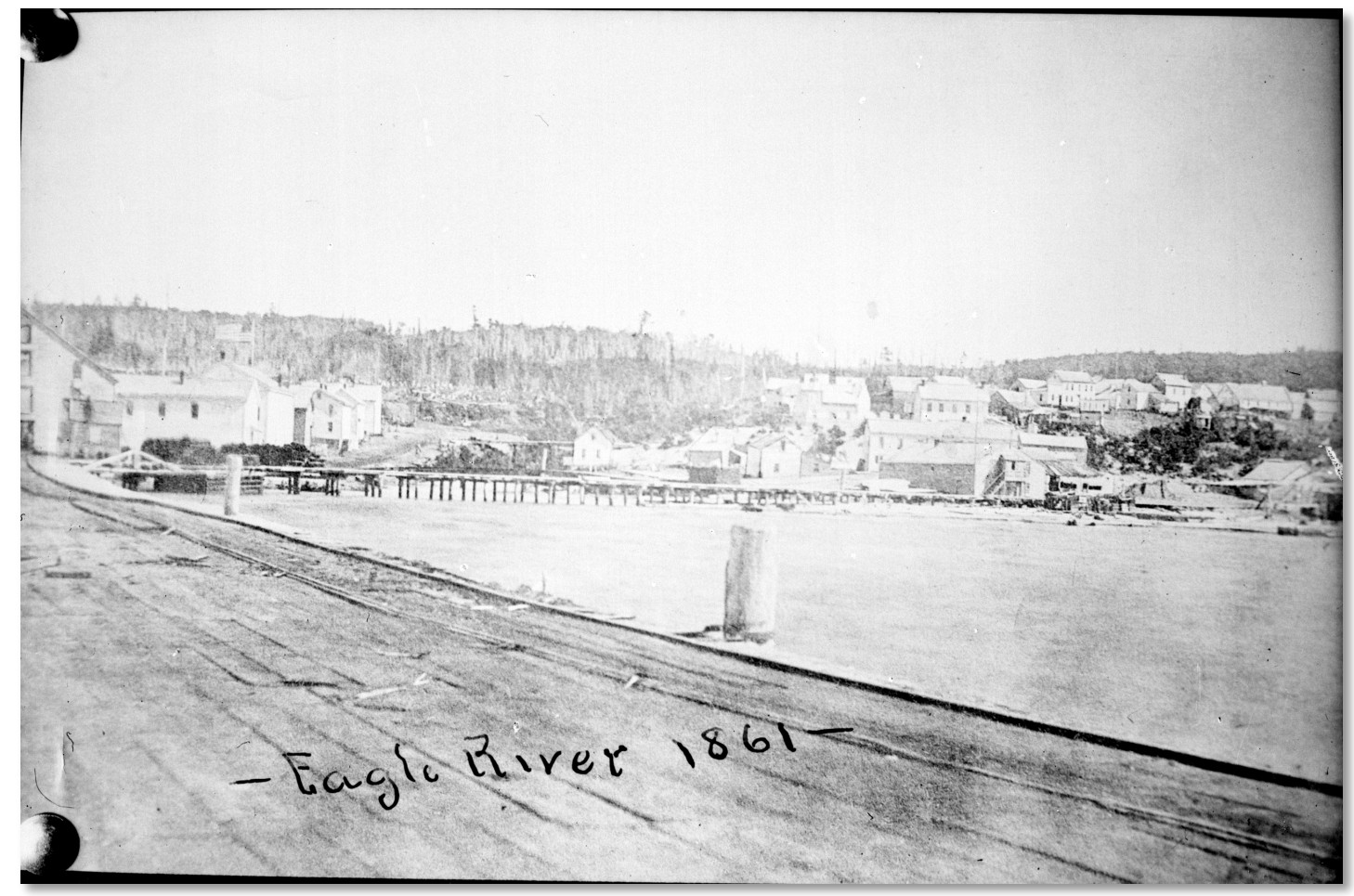

Fig. 4-1. Cliff Mine dock at Eagle River. All copper removed from the mine arrived at the dock via team-drawn wagon. Here, awaiting steamers were loaded with Cliff copper and then left for the smelters of Baltimore, Boston, and Pittsburgh. (Michigan Tech Archives and Copper Country Historical Collections)

"Doubtless you are as ready now to leave the mine as you were to enter it. We have now one hundred and eighty feet of ladder to climb; but, by perseverance, stopping a moment occasionally to take a breath, we shall soon be at the top. Now we emerge from a world of darkness into a world of light. We may now return to the office, and assume our own attire, by which time it would be no very strange thing if a good meal would relish well."

Through the combination of documentary research and fieldwork, the technical systems of the Cliff Mine are better understood. What is evident from the data acquired is that the very feature that gave the mine its name dictated the decisions made by the

\footnotetext{
${ }^{1}$ Rev. John H. Pitezel, Lights and Shades of Missionary Life: Containing Travels, Sketches, Incidents, and Missionary Efforts During Nine Years Spent in the Region of Lake Superior (Cincinnati: Western Book Concern, 1857), p.174.
} 
Pittsburgh \& Boston Mining Company during their ownership of the property. The vein's discovery at the top of the Greenstone Bluff gave the company its first challenge, since the bluff sat atop the vein, obscuring its detection from above. The earliest workings at the mine therefore focused on the base of the cliff, the only location where the copper vein could be worked easily, since they only had human and horse power at hand. As they dug deeper, they began to understand how the Greenstone Bluff dictated the alignment of the vein, forcing it further downward and north.

Over time, the mine prospered. This prosperity allowed the company to adopt steam power, which made following the vein easier. The workings expanded to meet the direction of the vein, and within 7 years of opening, the mine sat above and below the bluff. Within another 7 years, nearly all of the underground work took place over 1200 feet from their original workings. The company had finally conquered the landscape feature that first challenged their patience 15 years earlier.

As the mine's workings spread out horizontally over the property, tramways and larger buildings were needed to meet the demands of a large-scale operation. Eventually, the company developed two additional mining locations entirely, the North and South Cliff mines. The spread of the workings reflected the thinly stretched workforce.

Eventually they could no longer keep running things profitably. The paying ground was too deep and there just weren't enough men on hand to make working the vein a worthwhile effort. The P\&BMC met the challenge of the Greenstone Bluff for roughly 25 years, and managed to make a healthy profit for most of them. The mine's technology could only take it so far. Eventually all mines become either too deep or pinched out. In the end, the towering cliff face painted by Robert S. Duncanson won out.

\section{Distinct Periods in the Mine's Development}

I propose that the Pittsburgh and Boston Mining Company's ownership of the Cliff Mine can best be understood by examining four distinct periods of occupation. Supported by images created with the help of GIS and GPS data, each of these periods is briefly described below. 


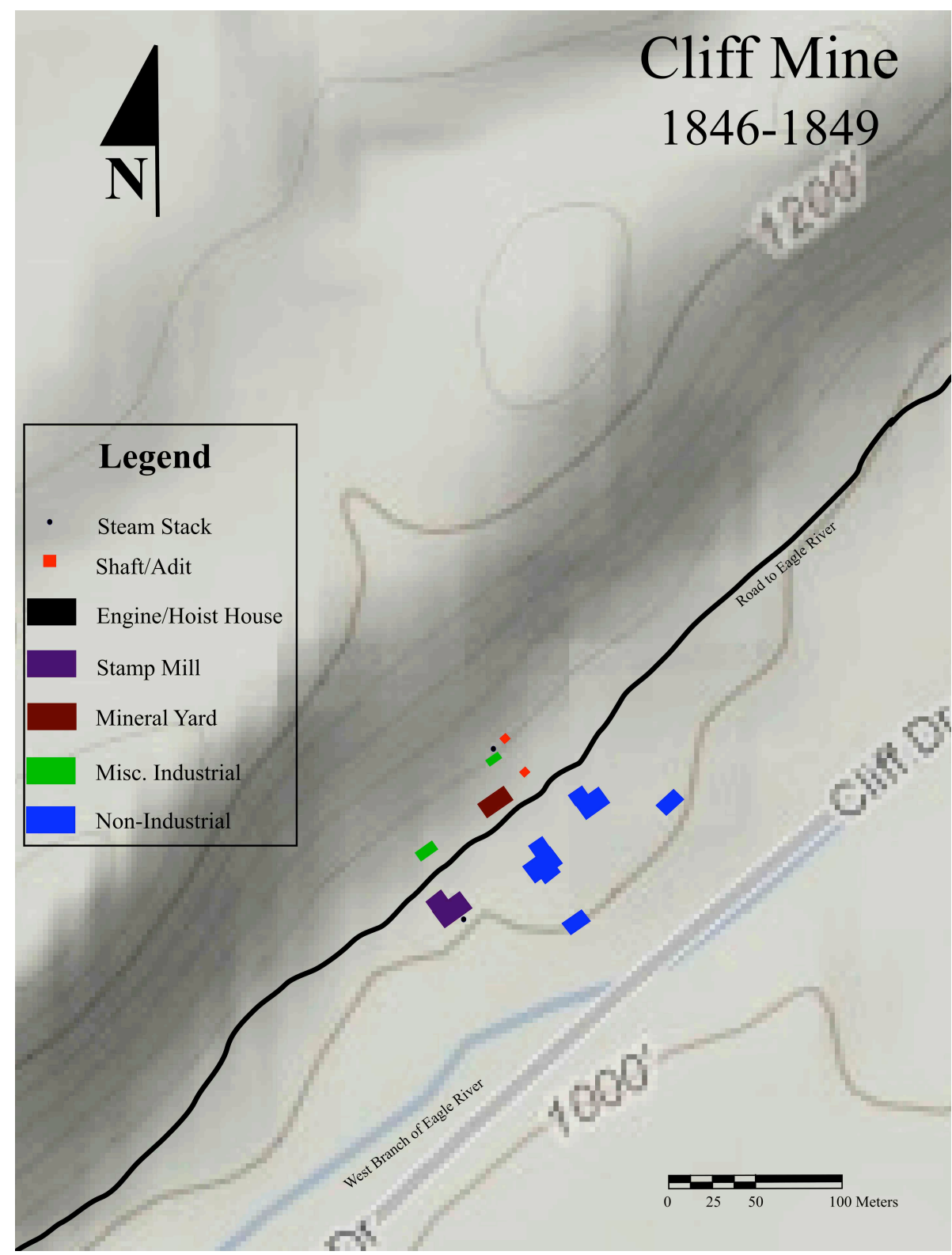

Fig. 4-2. Cliff Mine, 1846-1849. (Image by Author)

1846-1849

In the earliest years of work, the mine was an exploratory mining camp more than a permanent settlement. Buildings were generally constructed out of timber collected from the surrounding woodlands. The workings and community huddled at the foot of the Greenstone Bluff, with the line blurred between industrial and habitation structures. The arrangement of structures without regard to future development is evidenced by their 
close proximity to each other. At this point in the mine's history, success and failure were equally possible outcomes.

With the exception of the stamp mill, all power at the mine came from the strength of men and animals. Horses wound and unwound whims, raising and lowering iron kibbles loaded with ore and supplies. Men turned a capstan, lowering timber to help support the underground workings. Ore and rock were broken up with hammers and fire before being crushed at a steam powered mill. Many tools were made and maintained at a small blacksmith shop located behind the mill. Supplies arrived by boat, then driven by teamsters to the workings from Eagle River over a muddy, uneven road.

By 1848 , the mine began to be a profitable enterprise, and declared the first of many dividends the following year. The directors of the Pittsburgh and Boston Mining Company were faced with deciding whether to keep the workings as they were or to invest in infrastructure. They chose the latter and built 25 new dwellings for the growing workforce.

\section{0-1855}

Investing in the mine's future began with the arrival of heavy steam machinery in 1850-51. Nicholas Vivian, a civil engineer living in Pittsburgh, built and installed two large vertical engines inside newly constructed stone buildings built over the sites of the original stamp mill and mine office. These new buildings may have been the first largescale stone structures built in the Keweenaw, and both were used continuously for the duration of the P\&BMC's ownership of the Cliff. Horse whims were now replaced by winding drums and wooden a-frames built over the shafts. With steam power, larger quantities of ore and mass copper were raised from the ever deepening mine, increasing the amount of waste rock littering the surface.

The increases in work production also meant digging deeper under the bluff in order to follow the vein. As the mine sunk, the vein moved north. The further north the workings developed, the worse their condition. They became clogged with waste rock, reducing ventilation. To alleviate the problem, the No. 3 Shaft (with associated engine/hoist house) was begun at the very top of the bluff. The mine now had another 


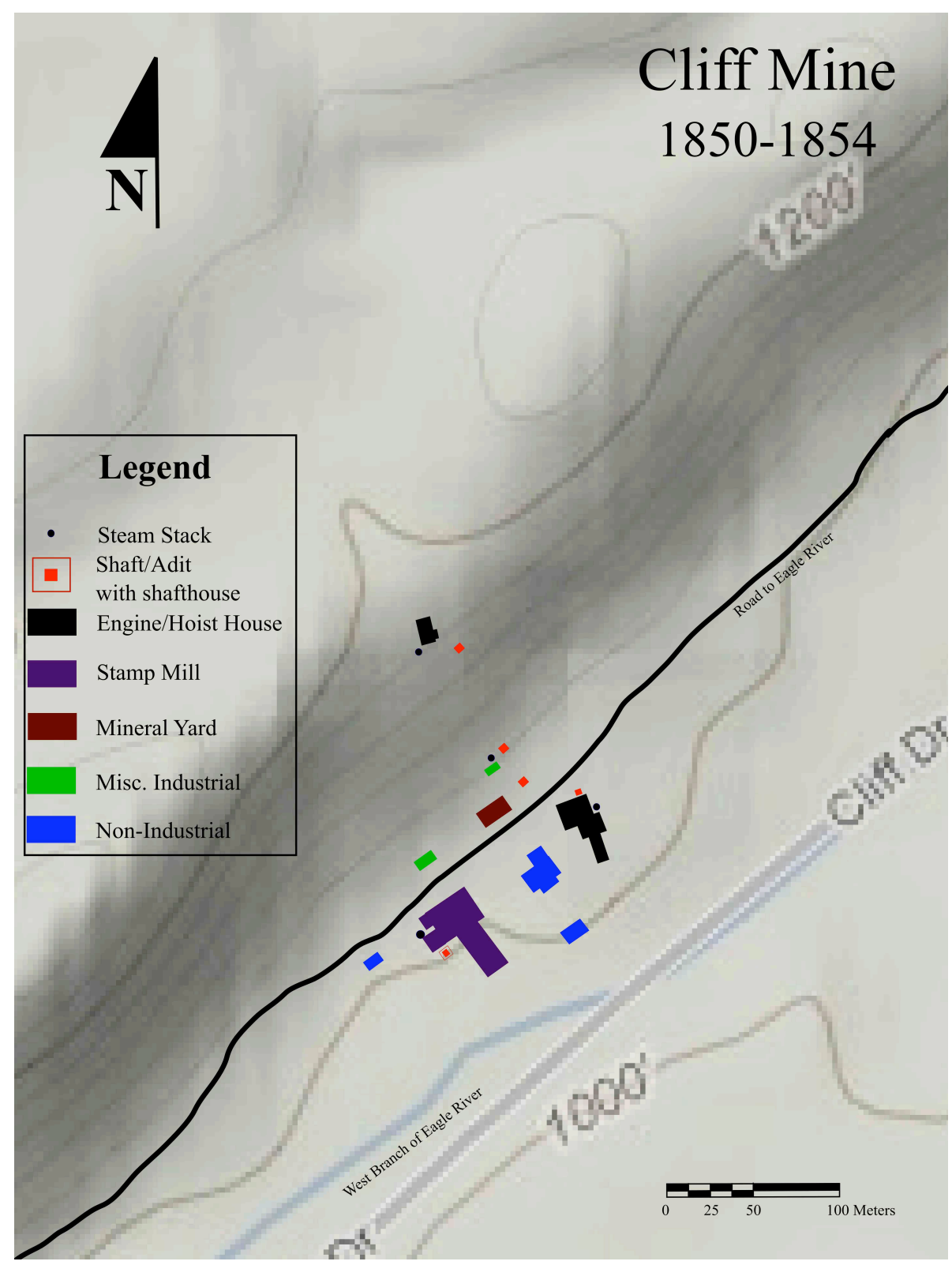

Fig. 4-3. Cliff Mine, 1850-1854. (Image by author)

exit point for waste rock, and soon the bluff face itself was transformed into a waste rock dump.

With a reliance on steam power comes another need; fuel, in this case timber. Supplying it in large quantities became an added requirement of the work at the mine. Large areas of the property were clear-cut to fill this need, exposing fertile ground to cultivation. Agriculture took root at the Cliff during this period, filling in the gaps created 


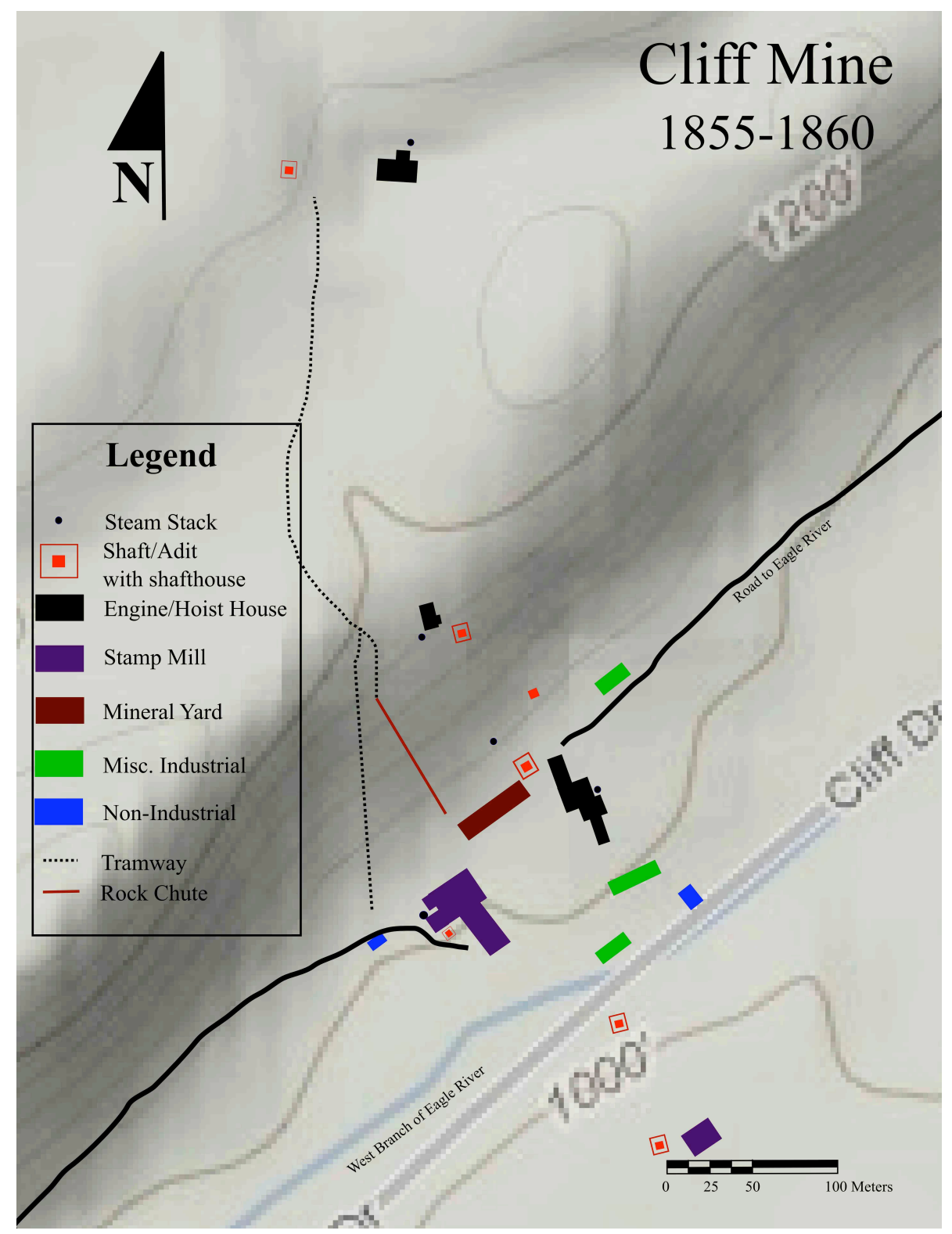

Fig. 4-4. Cliff Mine, 1855-1860. (Image by author)

by timber cutting and supplying much needed produce for the growing workforce. The mine's location began to look more and more like a community, not just a mining camp. 


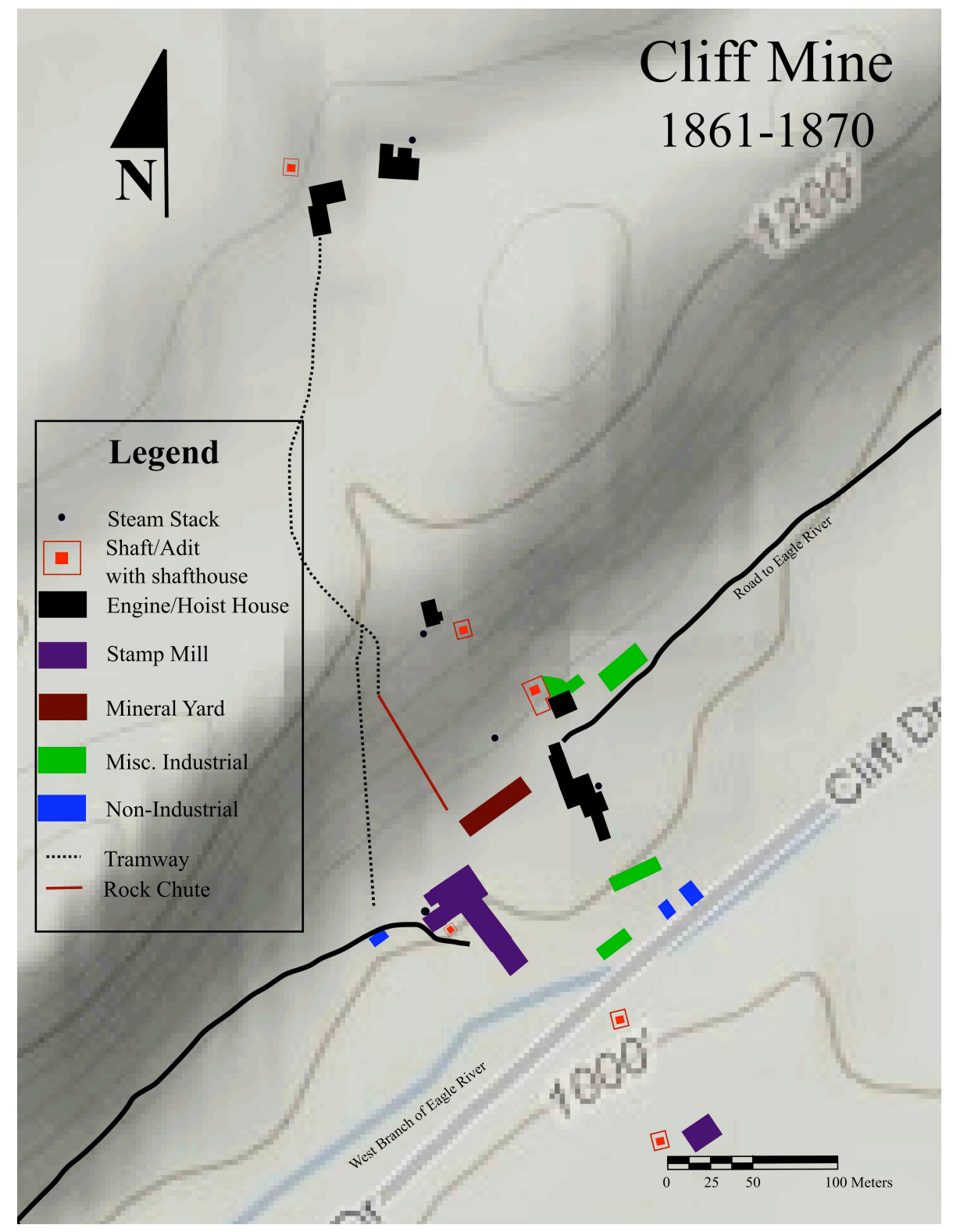

Fig. 4-5. Cliff Mine, 1861-1870. (Image by author)

\section{6-1860}

The mid 1850's saw the mine undergo a transformation as workings continued north. Under the direction of superintendent John Slawson, a focus on modernization and growth took over the mine. More homes and community buildings were built across the river to the south, in the new community of Clifton. At the base of the bluff, large stone buildings, industrial support structures mostly, were built. These included a new $150 \mathrm{ft}$ 
mineral house, a new machine shop, and a hoist house for the newly begun Avery Shaft. To meet the challenge of a northward (and downward) moving vein, the Howe (No. 4) Shaft was also begun $1000 \mathrm{ft}$ north of the No. 3 . The mine now contained 3 distinct surface plants, with tramways and rock chutes connecting the bluff-top workings to the mill below.

The community reached its zenith of 1500 residents spread out around the mine workings. At this time the separation between industrial and community occupied areas developed, with waste rock piles and the west branch of the Eagle River providing welldefined borders between the two. It should be noted however, that the P\&BMC acquired the North American Mining Company's workings south of the river at the end of this period, and although never directly worked by the Cliff, it did somewhat blur the line between the mine and the mine's community.

$1861-1870$

The blur between community and industrial spaces increased during the last period of the P\&BMC's ownership of the Cliff Mine, the 1860's. The company faced worker shortages due to competition from the Civil War and younger mines, and had to economize the workings and accommodate the workforce they had in order to keep the Cliff profitable.

The underground workings were now mostly confined to areas directly below and to the north of the Howe Shaft, requiring two engines to hoist both waste rock and mass copper. Another mineral yard, or kiln and rock houses, was constructed to prepare the ore before being trammed 1000 feet to the rock chute at the edge of the bluff. At least two large boarding houses were also built just to the north of these workings to house the men who worked at the mineral yard or maintained the steam engines.

The most important undertaking at the mine at this time was the installation of the man-engine at the Avery Shaft. This machine allowed miners to descend the mine in a fraction of the time it formerly did, allowing for more time underground spent drilling, blasting, and cutting up copper. The man-engine and pumping equipment were housed in the large stone shafthouse built over the Avery, the last large-scale building project to 
take place at the mine. Other projects, such as lengthening the washhouse and machine shop were also undertaken, but the 3-4 story Avery shafthouse symbolized the endpoint of the mine's growth.

Across the river to the south, Clifton grew and absorbed the workings of the South Cliff (formerly North American). The new road to Eagle River no longer passed by the mine. Instead it followed the division between the community and the industrial core, with the decision to do so possibly being aided by the congestion caused by waste rock filling the gap between the bluff and the river. The company hoped to keep moving south as well, extensively exploring the southern edges of the property in the hopes of hitting other paying lodes. They never did however, and by the end of the decade the P\&BMC called it quits. If the Cliff had anything more to give, other companies would be the ones to find out.

\section{Summation}

What is left at the site is now for the most part still identifiable. Engine houses, mill buildings, and industrial support structures can all be documented with the aid of digital mapping technologies. The links between those structures, the tramways and paths used by workers, can also still be seen after some precision clearing. Just as the landscape was the greatest challenge to the Cliff Mine during its heyday, the landscape provided the greatest challenge to documentation efforts. However, the fieldwork conducted during the spring of 2010 clearly proves that even the most inhospitable and difficult terrain can be effectively mapped using the latest mapping technologies available.

Using GIS and GPS, the movement of the Cliff Mine's workings from the base of the Greenstone Bluff to the Howe Shaft $1200 \mathrm{ft}$ north of it can be accurately documented. Starting with the base of the bluff, the No.'s 1 and 2 Shafts, the first engine house, the mineral yard, and stamp mill were all identified in order to understand the first decade of work at the mine. Fieldwork then moved up the bluff, mimicking the movement of the mine's industrial structures, and identified the No. 3 Shaft and engine house. Later the Howe Shaft surface plant, the last shaft sunk from the surface, was documented. Back at the base of the bluff the Avery shafthouse, home to the man-engine, provided a link 
between the workings and the men who expanded them. Finally, the tramway that linked the Howe to the stamp mill down below was uncovered and mapped, reconstructing how the mine was able to keep all of its workings connected in one system.

By identifying industrial structures, the locations of specific technology and machinery are better understood. Historical documents explain what and where steam engines, stamps, and washing equipment were housed, but by successfully documenting the exact locations of those structures we now have a suitable context in which to place those technologies. We know that the stamp mill housed one engine for its entire operation, and that it powered 36 Cornish style stamps, 8 of Hodge's design (for a time), and up to 12 Asmus' automatic jigging machines. The engine houses for each shaft also contained large steam engines, some vertically oriented (like at the Howe and Avery), other probably horizontal (various winding engines).

Together, an understanding of the Cliff Mine's historical record and the field data acquired on site provide an effective example of documentation of an early native copper mining site in the Lake Superior region. Through this documentation, a better understanding of the mine's adaptation to its surroundings, both technologically and physically, can be seen. 


\section{Chapter 5:}

\section{Recommendations}

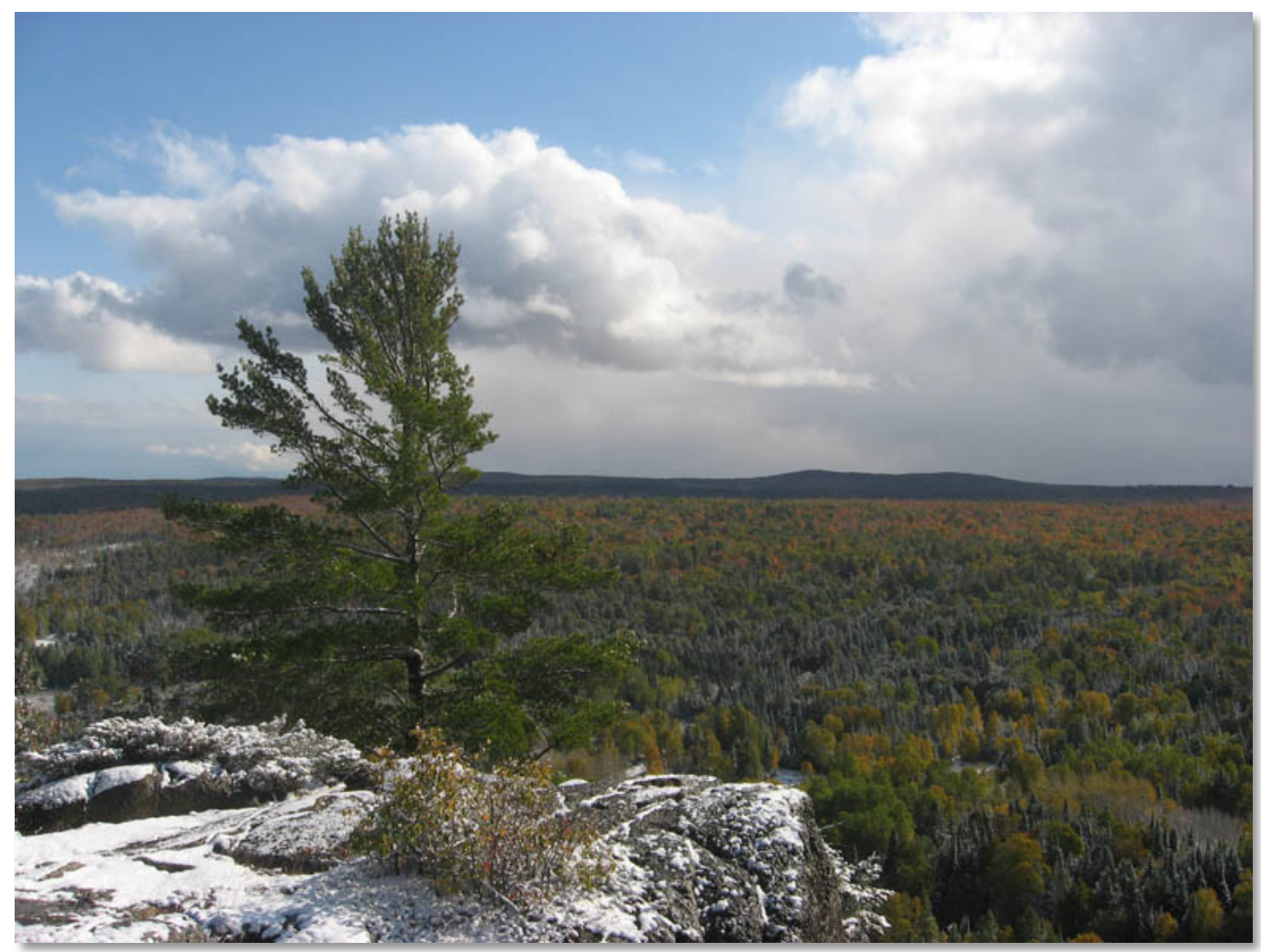

Fig. 5-1. The view south from the Cliff bluff, standing just west of the Cliff Mine's surface workings. (Image by author)

"If the reader thinks this description of the Cliff Mine too minute, it may be a source of relief that this much suffice for all the other mines of Lake Superior-to explore one thoroughly is to see the leading features of all the rest."

\section{Directions for Further Research: Historical Sources}

The Michigan Technological Archives and Copper Country Historical Collections (located in the Garden Level of the J.R. Van Pelt and Opie Library), are home to the largest collection of documents and images associated with the Cliff Mine. No matter how thorough a researcher may be, there are doubtless numerous items of information yet

\footnotetext{
${ }^{1}$ Rev. John H. Pitezel, Lights and Shades of Missionary Life: Containing Travels, Sketches, Incidents, and Missionary Efforts During Nine Years Spent in the Region of Lake Superior (Cincinnati: Western Book Concern, 1857), p.174.
} 
to be uncovered in these collections. Of particular interest to this researcher is the great variety of historic photographs to be found of the Cliff and Clifton. Many images are currently available through the Keweenaw Digital Archives, the web-based project of the MTU Archives to make Keweenaw history more accessible to the general public. Over time, it is hoped that more images of the mine and those who lived there will be found and uploaded to the site.

While scanning mid nineteenth century newspapers of the Upper Peninsula in the hopes of finding a mention of the Cliff Mine, this researcher was struck by the advertising techniques used by mine equipment manufacturers. The newspaper ads of the time generally took up $2 / 3$ of the print in these papers, and competition for reader's attention was fierce. Letters to the editor, authored by names as conspicuous as "Cousin Jack's Uncle" appeared to be more like testimonials for specific technologies, not the musings of a curious or excited reader. ${ }^{2}$ A look at the art of advertising during this period in terms of mining equipment may be another interest avenue of inquiry.

The information available about the Cliff Mine (as well as other Keweenaw mines) and its investors at the MTU Archives and elsewhere also lends itself to a detailed examination of early corporate structure of mining operations in America. Many of the directors of these companies, and certainly most of the investors, never set foot anywhere near a mineshaft. Understanding how these corporations operated, often without clear knowledge of the industry, may shed light on the decision making happening at the mine's surface.

Libraries in Pittsburgh and Boston, the two home cities of the Pittsburgh \& Boston Mining Company’s directors, may also hold documents relating to the mine, specifically in regards to the P\&BMC's corporate structure. The University of Pittsburgh library and Carnegie Library are known to each hold collections regarding Mr.'s Avery, Howe, Hussey, et al. Harvard University's Baker Library is another place to look for information dealing with the business practices of Keweenaw copper mines, since Boston contained probably the largest collection of investors associated with the industry.

\footnotetext{
${ }^{2}$ A series of letters from Nicholas Vivian, in rebuttal to letters to the editor from a Cousin Jack's Uncle (a pseudonym for Samuel Hodge) can be found in the bi-weekly editions Lake Superior Miner strecthing from August to November of 1867. Both Vivian and Hodge built equipment for the Cliff, and both were fierce propenents for competing forms of stamp machinery.
} 


\section{Directions for Further Research: Archaeology}

Further archaeological research at the Cliff Mine site should begin with continued mapping of the industrial core and Clifton townsite with Total Station GIS equipment. The 2010 field season managed to document much of the core areas but the level of detail, such heights of the structures for example, could be increased. The townsite provides an additional challenge due to much of it being either heavily forested or in swamp, but an accurate map of the entire site is integral to understanding the social networks of the mine and its community.

Along with GIS mapping, the site is a prime candidate for mapping with Light Detection and Ranging technology (LiDAR). A remote sensing technology that uses laser range finding to calculate distances between the light's source and its target, LiDAR is effective in detecting archaeological sites obscured by dense vegetation. Recently, LiDAR scans of Isle Royale National Park (another site of nineteenth century copper mining) demonstrated its effectiveness as a research strategy, and uncovered previously unknown cultural features within the Park's boundaries. ${ }^{3}$ It is hoped that in the future, a large scale LiDAR scan like that at Isle Royale could be made of the Cliff Mine's historic landscape to better understand the site's place within the Keweenaw.

Two weeks prior to the 2010 field season, students and faculty from Michigan Technological University's Forest Resources and Environmental Science, Industrial Archaeology, Civil and Environmental Engineering, and Surveying Engineering departments tested an upright stationary LiDAR scanner at two of the Cliff Mine site's operational zones, the Stamp Mill and Howe Shaft. The scans, while not included in this thesis, may become important tools in future research as they demonstrated LiDAR's effectiveness at imaging landscape and structural remains.

In terms of excavation, both the industrial core and Clifton townsite are prime candidates for further investigation. The townsite offers a look into the lifeways of the workers (both management and miner) and their families, as well as the social networks and connections created in industrial company towns during the mid nineteenth century.

\footnotetext{
${ }^{3}$ Gallagher, Julie M. and Josephs, Richard L., "Using LiDAR to detect cultural resources in a forested environment: An example from Isle Royale National Park, Michigan, USA," Archaeological Prospection 15.3 (2008): 187-206.
} 
The industrial core, specifically the mill and engine houses, provide excellent examples of construction techniques and decisions made in the early periods of copper mining in the Keweenaw. The mill, which underwent many changes over the different periods of mine management and ownership, is also surrounded by stamp sand, a great natural preserver of wooden features. Excavations at the copper mine site of Norwich Mine in Ontonagon County, MI demonstrated the preservative qualities of stamp sand; if similar circumstances are found at the Cliff's mill, answers to the milling technology of the time could be forthcoming. ${ }^{4}$ Excavating the engine house structures could also narrow the possibilities for locations of specific equipment, thereby broadening researchers understandings of the technical layouts of the structures.

\section{Preservation and Public Interpretation}

Without question the first recommendation needs to be to preserve the Cliff Mine site for future enjoyment. Whether plans for its preservation are carried our by the site's current owner, the Keweenaw County Road Commission, or a future owner, the site is too important to the story of American mining history to be left to decay. Currently, guided tours of the site during the summer months are undertaken by Michigan Technological University's Industrial Archaeology program (Houghton, MI), the Keweenaw County Historical Society (Eagle Harobr, MI), and the Keweenaw National Historic Park (Calumet, MI), and follow clearly marked trails. The site and trails lack interpretive signage however, and without the benefit of a guide, understanding the landscape and features of the site are difficult.

Previously mentioned historical images found at the Michigan Technological Archives and Copper Country Historical Collections can be useful in the creation of interpretive panels (and/or walking tour pamphlets) that could be placed around the site to help orient visitors and provide historical context to the current state of the landscape. As there is already a well marked trail, a interpretive trail route would not need to intrude

\footnotetext{
${ }^{4}$ Landon, David and Tumberg, Timothy. "Archaeological Perspectives on the Diffusion of Technology: An Example from the Ohio Trap Rock Mine," IA 22.2 (1996): 41-57; Kelly Jo Dixon, Industrial Archaeology of the Ohio Trap Rock Mine: Report of Investigations Number 20, Michigan Technological University (Houghton, 1994), pps.113-146.
} 
on the landscape as it stands, and therefore would require little maintenance and planning.

The structural remains at the Cliff Mine site are for the most part stable considering their age and lack of attention for the last century. All the large industrial core features, the engine houses, stamp mill, and steam stacks, will however fall into a state of irreparable decay over the next decades if something isn't done to prevent it. Capping the stone foundation walls and initiating a plan for stabilization is recommended for these structures regardless whether or not a preservation plan is forthcoming in the near future. The sort of capping/stabilization of stone structural remains recently carried out at the Quincy Mine Hoist Association's Quincy Mine property is just one example of delicate stabilization work that respects the integrity of an historical property while still preserving its structural integrity. ${ }^{5}$

Currently, the properties surrounding the Cliff Mine site are subject to logging, and although nearly all the industrial core of the site is outside the reach of logging activity, much of the townsite of Clifton is not. During the 2010 field season, archaeologists detected the effects of logging on the historic landscape, such as the partial collapse of a rock pile near the Howe Shaft due to the cutting in of a logging access road. Also encountered were examples of sensitivity however; the flagging of the South Cliff No. 3 engine house and steam stack was one instance where loggers avoided disturbing a possibly culturally significant feature. It is hoped that in the future, as logging continues in and around the site, a delicate hand is used in managing the timber resources in and around the site.

\footnotetext{
${ }^{5}$ Mining Gazette. 22 July 2009.
} 


\section{Bibliography:}

\section{$\underline{\text { Books }}$}

Baxter, James Phinney. A Memoir of Jacques Cartier: Sieur de Limoilou, His Voyages to the St. Lawrence a Bibliography and a Facsimile of the Manuscript of 1534, with Annotations, etc. New York: Dodd, Mead \& Company, 1906.

Bradish, Alvah. Memoir of Douglass Houghton, First State Geologist of Michigan. Detroit: Raynor and Taylor, 1889.

Butterfield, Consul Willshire. History of Brule's Discoveries and Explorations 1610-1626: Being a Narrative of the Discovery, by Stephen Brule, of Lakes Huron, Ontario and Superior; and of His Explorations (the First Made by Civilized Man) of Pennsylvania and Western New York, also of the Province of Ontario, Canada: with a Biographical Notice of the Discoverer and Explorer, who was Killed and Eaten by Savages. Cleveland: The Hellman-Taylor Company, 1898.

Champlain, Samuel de. Voyages of Samuel de Champlain: 1604-1618. Ed. W.L. Grant. New York: Charles Scribner's Sons, 1907.

Chaput, Donald. The Cliff: America's First Great Copper Mine. Kalamazoo: Sequoia Press, 1971.

Clarke, Don H. Copper Mines of the Keweenaw, The Cliff Mine. 1976.

Costain, Thomas Bertram. The White and the Gold: The French Regime in Canada. Garden City: Doubleday \& Company, Inc., 1954.

De Bow, J.D.B. "Copper Mines: Commerce of Lakes Erie, Huron, Michigan, etc. ." De Bow's Review: Devoted to the Restoration of the Southern States and the Development of Wealth and Resources of the Country. 1853: 493-494.

Fadner, Lawrence T. Fort Wilkins, 1844, and the U.S. Mineral Land Agency, 1843. New York: Vantage Press, 1966.

Fisher, J. Historical Sketch of the Lake Superior Copper District. Houghton: Michigan College of Mines, 1924.

Hubbard, Bela. Memorials of a Half-Century in Michigan and the Lake Region. New York: Putnams' Sons, 1888 .

Hunter, Louis C. A History of Industrial Power in the United States1780-1930. Vol. II. Charlottesville: Hagley Museum and Library, 1985. III vols.

Kellogg, Louise Phelps. The French Regime in Wisconsin and the Northwest. Madison: State Historical Society of Wisconsin, 1925.

Krause, David J. The Making of a Mining District: Keweenaw Native Copper 1500-1870. Detroit : Wayne State University Press, 1992.

Lankton, Larry. Cradle to the Grave: Life, Work, and Death at the Lake Superior Copper Mines. New York: Oxford Univeristy Press, 1991. 
Mason, Philip P., ed. Copper Country Journal: The Diary of Schoolmaster Henry Hobar, 1863-1864. Detroit: Wayne State Press, 1991.

Monette, Clarence. Clifton and the Cliff Mine. Calumet: Greenlee Printing Co., 1999.

Murdoch, Angus. Boom Copper: The Story of the First Mining Boom. Hancock: The Quincy Mine Hoist Association, 2001.

Pitezel, Rev. John H. Lights and Shades of Missionary Life: Containing Travels, Sketches, Incidents, and Missionary Efforts During Nine Years Spent in the Region of Lake Superior. Cincinnati: Western Book Concern, 1857.

Radisson, Pierre Esprit. Voyages of Peter Esprit Radisson: Being an Account of His Travels and Experiences Among the North American Indians, from 1652-1684. Ed. G.D. Scull. Boston: Prince Society, 1885.

Thwaites, Rueben Gold. The Jesuit Relations and Allied Documents: Travels and Explorations of the Jesuit Missionaries in North America (1610-1791), With an Introduction by Reuben Gold Thwaites. Ed. E. Kenton. New York: Albert \& Charles Boni, 1925.

Verwyst, Rev. C.P. Missionary Labors of Fathers Marquette, Menard and Allouez, in the Lake Superior Region. Chicago: Hoffmann Brothers, 1886.

Western Historical Co., History of the upper peninsula of Michigan: containing a full account of its early settlement, its growth, development, and resources, an extended description of its iron and copper mines Chicago: Western Historical Co., 1883.

Whitney, J.D. The Metallic Wealth of the United States: Described and Compared with that of Other Countries. Philadelphia: Lippincott, Grambo \& Co., 1854.

Whittlesey, Charles. Ancient Mining on the Shores of Lake Superior. Washinton : Smithsonian Institution, 1863.

Williams, Ralph, D. The Honorable Peter White, a biographical sketch of the Lake Superior iron country. Cleveland: Pention Publishing Co. , 1907.

\section{Articles/Book Sections}

Crane, W.R. "Mining Methods and Practice in the Michigan Copper Mines." Bulletin U.S. Bureau of Mines 1929: 1-189.

Egleston, Thomas. "Copper Refining in the united States." Transactions of the American Institute of Mining Engineers; May 1880 to February 1881 1881: 678-730.

Hybels, Robert James. "A Narrative of the Lake Superior Copper Fever, 1841-47." Michigan History June 1950: 97-119, 224-244, 309-326.

Josephs, J.M., and Gallagher, R.L. "Using LiDAR to detect cultural resources in a forested environment: An example from Isle Royale National Park, Michigan, USA," Archaeological Prospection 15.3 (2008): 187-206. 
"Journal of Copper Mining Operations: Lake Superior Region." The Mining Magazine: Devoted to Mines, Mining Operations, Metallurgy, etc. 5 (1855): 164-173.

Journal of Mining and Manufactures. "Production of Copper at the Cliff Mine." Merchant's Magazine and Commercial Review 1849: 574-575.

Leitner, Jonathan. "The 1869 Copper Tariff: The Politics and Geography of Postbellum U.S. Development in World Systems Perspective." Sociological Perspectives 43.3 (2000): 473-497.

Pettit, William. "Remarks Respecting the Copper District of Lake Superior, Made at the Monthly Meeting of the Franklin Institute, March 18th, 1847." Journal of the Franklin Institute XLIII (1847): 338345 .

Porter, George. "Appendix ." McKenney, Thomas L. Sketches of a Tour to the Lakes, of the Character and Customs of the Cippeway Indians, and of Incidents Connected with the Treaty of Fond du Lac. Baltimore: F. Lucas Jr. , 1827. 479-486.

Rawlings, Joseph. "Recollections of a Long Life." Drier, Roy W. Copper Country Tales Vol I. Calumet: RoyDrier, Publ., 1967. 98-119.

"Journal of Copper Mining Operations." Mining Magazine: Devoted to Mines, Mining Operations, Metallurgy, etc. 1853: 632-642.

"Journal of Copper Mining Operations." Mining Magazine: Devoted to Mines, Mining Operations, Metallurgy, etc. 1854: 193-206.

Van Pelt, John Robert. "Boston and Keweenaw: An Etching in Copper." Mining and Metallurgy Spring (1949): 4-8.

\section{Periodicals:}

\section{Lake Superior Miner}

Lake Superior News \& Mining Journal

\section{Mining Gazette}

\section{New York Times}

Clarke, Robert E. "Notes from the Copper Region." Harper's New Monthly Magazine March, April 1853: 433-448, 577-588.

"The Mines and Miners of Cornwall." Lake Superior Journal 2 Sept. 1854. 


\section{$\underline{\text { Scholarly and Technical Reports }}$}

Andrews, Eleanor De Ling. The Cliff Mine Site A Historical and Archeological Study: Fieldwork through Michigan Technological University in 1973. 2005.

Dixon, Kelly Jo. Industrial Archaeology of the Ohio Trap Rock Mine: Report of Investigations Number 20, Michigan Technological University. Houghton, 1994.

\section{Primary Sources: Company Reports}

Calumet And Hecla Mining Company,

“Tamarack Mining Company." Annual Report for the Year Ending April 30, 1909. 48-58. Boston, 1909.

"Tamarack Mining Company." Annual Report for the Year Ending April 30, 1910. 39-43. Boston, 1910.

"Tamarack Mining Company." Annual Report for the Year Ending April 30, 1911. 64-70. Boston, 1911.

"Tamarack Mining Company." Annual Report for the Year Ending April 30, 1912. 58-63. Boston, 1912.

Cliff Mining Company,

Annual Report for the Year Ending December 31, 1910. Boston, 1910.

MTU Archives and Copper Country Historical Collections. Clarence Monette Collection, MS-058, Box 27, Folder 4.

Annual Report for the Year Ending December 31, 1911. Boston, 1911.

MTU Archives and Copper Country Historical Collections. Clarence Monette Collection, MS-058, Box 27, Folder 4.

Annual Report for the Year Ending December 31, 1912. Boston, 1912.

MTU Archives and Copper Country Historical Collections. Clarence Monette Collection, MS-058, Box 27, Folder 4.

Annual Report for the Year Ending December 31, 1913. Boston, 1913. MTU Archives and Copper Country Historical Collections. Clarence Monette Collection, MS-058, Box 27, Folder 4.

Annual Report for the Year Ending December 31, 1914. Boston, 1914.

MTU Archives and Copper Country Historical Collections. Clarence Monette Collection, MS-058, Box 27, Folder 4. 
Annual Report for the Year Ending December 31, 1915. Boston, 1915.

MTU Archives and Copper Country Historical Collections. Clarence Monette Collection, MS-058, Box 27, Folder 4.

Annual Report for the Year Ending December 31, 1916. Boston, 1916.

MTU Archives and Copper Country Historical Collections. Clarence Monette Collection, MS-058, Box 27, Folder 4.

Annual Report for the Year Ending December 31, 1917. Boston, 1917.

MTU Archives and Copper Country Historical Collections. Clarence Monette Collection, MS-058, Box 27, Folder 4.

Annual Report for the Year Ending December 31, 1918. Boston, 1918.

MTU Archives and Copper Country Historical Collections. Clarence Monette Collection, MS-058, Box 27, Folder 4.

Annual Report for the Year Ending December 31, 1919. Boston, 1919.

MTU Archives and Copper Country Historical Collections. Clarence Monette Collection, MS-058, Box 27, Folder 4.

Annual Report for the Year Ending December 31, 1920. Boston, 1920.

MTU Archives and Copper Country Historical Collections. Clarence Monette Collection, MS-058, Box 27, Folder 5 .

Annual Report for the Year Ending December 31, 1924. Boston, 1924.

MTU Archives and Copper Country Historical Collections. Clarence Monette Collection, MS-058, Box 27, Folder 5.

Annual Report for the Year Ending December 31, 1925. Boston, 1925.

MTU Archives and Copper Country Historical Collections. Clarence Monette Collection, MS-058, Box 27, Folder 5.

Annual Report for the Year Ending December 31, 1926. Boston, 1926.

MTU Archives and Copper Country Historical Collections. Clarence Monette Collection, MS-058, Box 27, Folder 5 .

Annual Report for the Year Ending December 31, 1927. Boston, 1927.

MTU Archives and Copper Country Historical Collections. Clarence Monette Collection, MS-058, Box 27, Folder 5 .

Annual Report for the Year Ending December 31, 1928. Boston, 1928.

MTU Archives and Copper Country Historical Collections. Clarence Monette Collection, MS-058, Box 27, Folder 5. 
Annual Report for the Year Ending December 31, 1929. Boston, 1929.

MTU Archives and Copper Country Historical Collections. Clarence Monette Collection, MS-058, Box 27, Folder 5.

Annual Report for the Year Ending December 31, 1930. Boston, 1930.

MTU Archives and Copper Country Historical Collections. Clarence Monette Collection, MS-058, Box 27, Folder 5.

Annual Report for the Year Ending December 31, 1931. Boston, 1931.

MTU Archives and Copper Country Historical Collections. Clarence Monette Collection, MS-058, Box 27, Folder 5 .

Annual Report for the Year Ending December 31, 1920. Boston, 1920.

MTU Archives and Copper Country Historical Collections. Clarence Monette Collection, MS-058, Box 27, Folder 5.

Annual Report for the Year Ended December 31, 1947. Boston, 1947.

MTU Archives and Copper Country Historical Collections. Clarence Monette Collection, MS-058, Box 27, Folder 5 .

Annual Report for the Year Ended December 31, 1949. Boston, 1949.

MTU Archives and Copper Country Historical Collections. Clarence Monette Collection, MS-058, Box 27, Folder 5 .

Annual Report for the Year Ended December 31, 1950. Boston, 1950.

MTU Archives and Copper Country Historical Collections. Clarence Monette Collection, MS-058, Box 27, Folder 5.

Annual Report for the Year Ended December 31, 1951. Boston, 1951.

MTU Archives and Copper Country Historical Collections. Clarence Monette Collection, MS-058, Box 27, Folder 5.

North Cliff Mining Company,

Articles of Assoiciation and By-Laws of the North Cliff Mining Company. Pittsburgh: W.S. Haven, 1858.

Report of the President and Directors of the North Cliff Mining Company. Pittsburgh: W.S. Haven, 1864.

Pittsburgh and Boston Mining Company,

Shepherd, Forrest. Geological Survey of the Mineral Lands of the Southern Shore of Lake Superior, Belonging to the Pittsburgh and Boston Copper Harbor Mining Company. Pittsburgh: George Parkin, 1846. 
Report of the Committee of the Stockholders of the Pittsburgh and Boston Copper Harbor Mining Company. Boston: Pittsburgh: George Parkin \& Co.,1847.

MTU Archives and Copper Country Historical Collections. Clarence Monette Collection, MS-058, Box 27, Folder 3.

Charter and By Laws of the Pittsburgh and Boston Mining Company of Pittsburgh. Articles of Incorporation. Pittsburgh: George Parkin \& Co., 1848.

Report of the President and Directors of the Pittsburgh and Boston Mining Company. Pittsburgh: George Parkin \& Co., 1849.

Report of the President and Directors of the Pittsburgh and Boston Mining Company. Pittsburgh: George Parkin \& Co., 1850.

Report of the President and Directors of the Pittsburgh and Boston Mining Company. Pittsburgh: George Parkin \& Co., 1851.

MTU Archives and Copper Country Historical Collections. Clarence Monette Collection, MS-058, Box 27, Folder 3

Report of the President and Directors of the Pittsburgh and Boston Mining Company. Pittsburgh: W.S. Haven, 1852.

MTU Archives and Copper Country Historical Collections. Clarence Monette Collection, MS-058, Box 27, Folder 3

Report of the President and Directors of the Pittsburgh and Boston Mining Company. Pittsburgh: George Parkin \& Co., 1853.

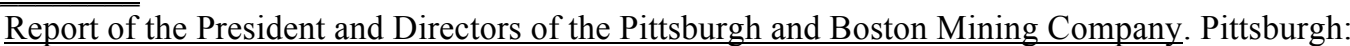
W.S. Haven, 1854.

MTU Archives and Copper Country Historical Collections. Clarence Monette Collection, MS-058, Box 27, Folder 3

Report of the President and Directors of the Pittsburgh and Boston Mining Company. Pittsburgh: W.S. Haven, 1855.

Report of the President and Directors of the Pittsburgh and Boston Mining Company. Pittsburgh: W.S. Haven, 1858.

MTU Archives and Copper Country Historical Collections. Clarence Monette Collection, MS-058, Box 27, Folder 3

Report of the President and Directors of the Pittsburgh and Boston Mining Company. Pittsburgh: W.S. Haven, 1859. 
Report of the President and Directors of the Pittsburgh and Boston Mining Company. Pittsburgh: W.S. Haven, 1860.

Report of the President and Directors of the Pittsburgh and Boston Mining Company. Pittsburgh: W.S. Haven, 1861.

Report of the President and Directors of the Pittsburgh and Boston Mining Company. Pittsburgh: W.S. Haven, 1864.

Report of the President and Directors of the Pittsburgh and Boston Mining Company. Pittsburgh: W.S. Haven, 1866.

MTU Archives and Copper Country Historical Collections. Clarence Monette Collection, MS-058, Box 27, Folder 3

Report of the President and Directors of the Pittsburgh and Boston Mining Company. Pittsburgh: W.S. Haven, 1868.

Report of the President and Directors of the Pittsburgh and Boston Mining Company. Pittsburgh: W.S. Haven, 1869.

MTU Archives and Copper Country Historical Collections. Clarence Monette Collection, MS-058, Box 27, Folder 3

Report of the President and Directors of the Pittsburgh and Boston Mining Company. Pittsburgh: W.S. Haven, 1870.

MTU Archives and Copper Country Historical Collections. Clarence Monette Collection, MS-058, Box 27, Folder 3

Report of the President and Directors of the Pittsburgh and Boston Mining Company. Pittsburgh: Stevenson, Foster \& Co., 1879.

MTU Archives and Copper Country Historical Collections. Clarence Monette Collection, MS-058, Box 27, Folder 3

\section{Primary Sources: Government Documents}

Foster, J.W. and Whitney, J.D. Report on the Geology and Topography of a Portion of the Lake Superior Land District. Washington: House of Representatives, Executive Doc. 69. 31st Congress. 1st Session., 1850.

Houghton, Douglass. Geological Reports of Douglass Houghton, First State Geologist of Michigan, 18371845. Ed. George, N. Fuller. Lansing: The Michigan Historical Commission, 1928.

Houghton, Jacob. Reports of William A. Burt and Bela Hubbard, esqs., on the Geography, Topography and Geology of the U.S. Surveys of the Mineral Region of the South Shore of Lake Superior, for 1845. Ed. J. \& Bristol, T.W. Houghton. Detroit: C. Wilcox, 1846. 
Jackson, Charles T. Report on the geological and mineralogical survey of the mineral lands of the United States in Michigan. U.S. Congress, Senate Exec. Doc. 1. Washington, 1849.

Trowbridge, S.V.R. "Trowbridge Report to the Michigan Secretary of State." Joint Documents of the Legislature (1850): 53-59.

Wright, Charles E. Annual Report of the Commissioner of Mineral Statistics of the State of Michigan, for 1880. Lansing: W.S. George \& Co. , 1881.

\section{Primary Sources: Patents}

Hodge, Samuel F. Ore-Crushing Machine. USA: Patent 17374. 26 May 1857.

Schell, Augustus W. Improved Machine for Separating and Cleaning Ores. USA: Patent 1531. 1 Sept. 1863.

\section{$\underline{\text { Archival Sources }}$}

Penberthy, E.R. "Letter from E.R. Penberthy to J.A. Doelle (Sec. and Treas.. of Keweenaw Historical Society) Dates Feb. 1st, 1913." Keweenaw Historical Society, 1 Feb. 1913. 1-6.

Field Journal/Survey Data Notebook: Cliff Mine Archaeology Project, 2010. Sean Gohman

Field Journal: Cliff Mine Archaeology Project, 2010. John Baeten

Field Journal: Cliff Mine Archaeology Project, 2010. Steve Moray

Field Journal: Cliff Mine Archaeology Project, 2010. William Deephouse

Field Journal: Cliff Mine Archaeology Project, 2010. Sam Sweitz

Field Journal: Cliff Mine Archaeology Project, 2010. Jessica Posega

Field Journal: Cliff Mine Archaeology Project, 2010. Sawyer Newman

Field Journal: Cliff Mine Archaeology Project, 2010. Lisa Gillis

Field Journal: Cliff Mine Archaeology Project, 2010. Kim Barton 


\section{Historic Photographs and Maps}

Michigan Tech Archives and Copper Country Historical Collections. Houghton, MI. 49931:

Harry Reeder Photograph Collection

Brockway Photograph Collection

Roy Drier Photograph Collection

William S. Thomas Photograph Collection

Mining Engineering Photograph Collection

Calumet \& Hecla Oversize Map Collection

Michigan Department of Natural Resources and Environment Core Sample Repository, Marquette, MI. 49980

\section{Websites}

Cliff Mine Archaeology Project Blog. 10 April 2010.

http://cliffmine.wordpress.com

Keweenaw Digital Archive, Michigan Technological University - Houghton, Michigan, USA.

http://digarch.lib.mtu.edu/

Michigan Geneaology on the Web. Cliff Catholic Cemetary. The USGenWeb Project. 7112009

$<$ www.mfhn.com/keweenaw/cemetaries/CliffCatholic.aspx>.

Accessed 25.May.2010.

Wikipedia

http://en.wikipedia.org/wiki/File:1842TreatyOfLaPointe.jpg Accessed 25.May.2010. 


\section{Appendix A:}

\section{Historic Images}

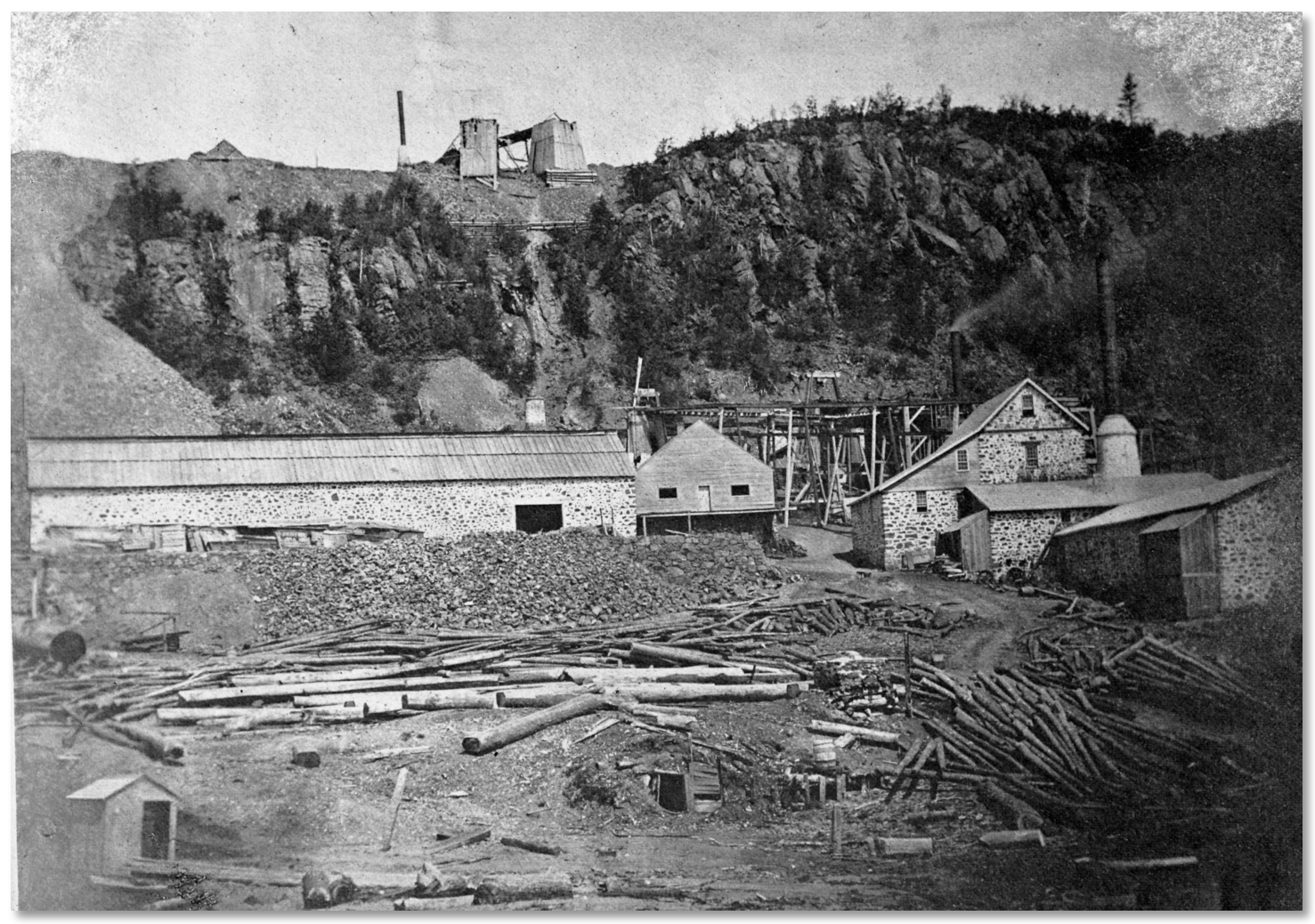

Fig. A-1. Earliest known photo of the Cliff Mine, taken circa 1857.Structures visible in the foreground from left to right are: $150 \mathrm{ft}$. mineral house, possible wood frame shaft house, main engine house (housing vertical beam engine) with steam stack and support buildings attached to the front. Behind the engine house are the No's 1 and 2 Shafts as well as the just begun Avery Shaft, which is marked by the wood framing (for the future shaft house that stood over it) and the large sheer (tallest A-Frame) that aided in lowering material during construction. At the top of the bluff is the No. 3 surface plant comprised of a shaft houses, steam stack, and engine house (only roof is visible). (MS042-040-999-T144, Reeder Photograph Collection. Michigan Tech Archives and Copper Country Historical Collections)

On Following Page:

Figs. $A-2, A-3$. Detail images of the engine house and Avery Shaft surface plant taken circa 1896. Fig. $2 a$ is taken from the SW and shows the later addition hoist house attached to the rear of the engine house. Also visible is the stone machine shop building at far right and the Avery Shaft

House located directly behind the engine/hoist houses. The eastern wall of the collapsed mineral house is visible in the left foreground. Fig. $3 a$ provides a view from SE of the surface plant. Note that a support building attached to the front of the engine house (as seen in Fig. 1a) is missing. Also visible are waste rock piles and another unknown stone structure (possibly a dry house of store house) at left. (MS042-036-P-026, Harry Reeder Photographic Collection. MTU Neg 05196, Charles Sincock Collection. Michigan Tech Archives and Copper Country Historical Collections) 


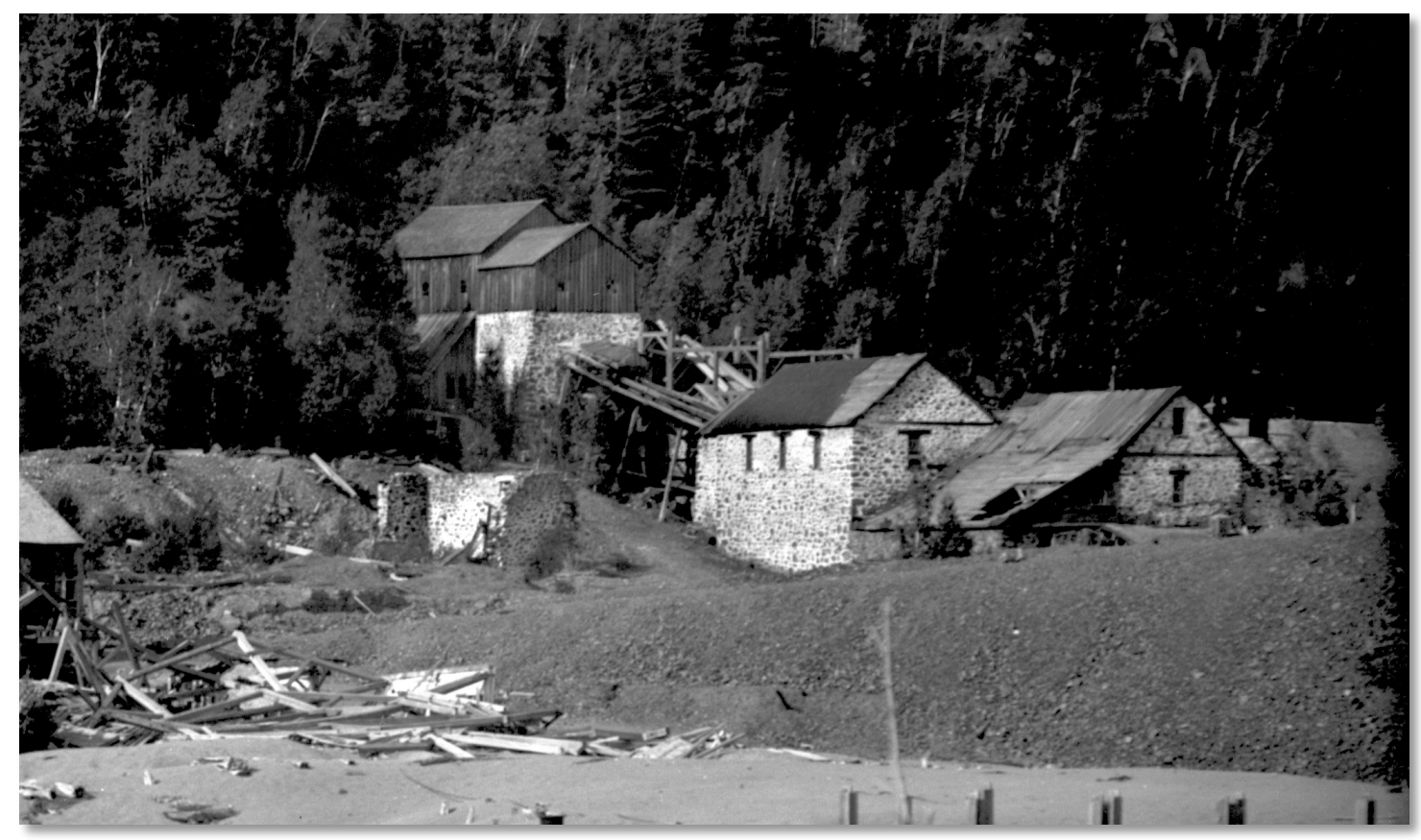

Fig. A-2.

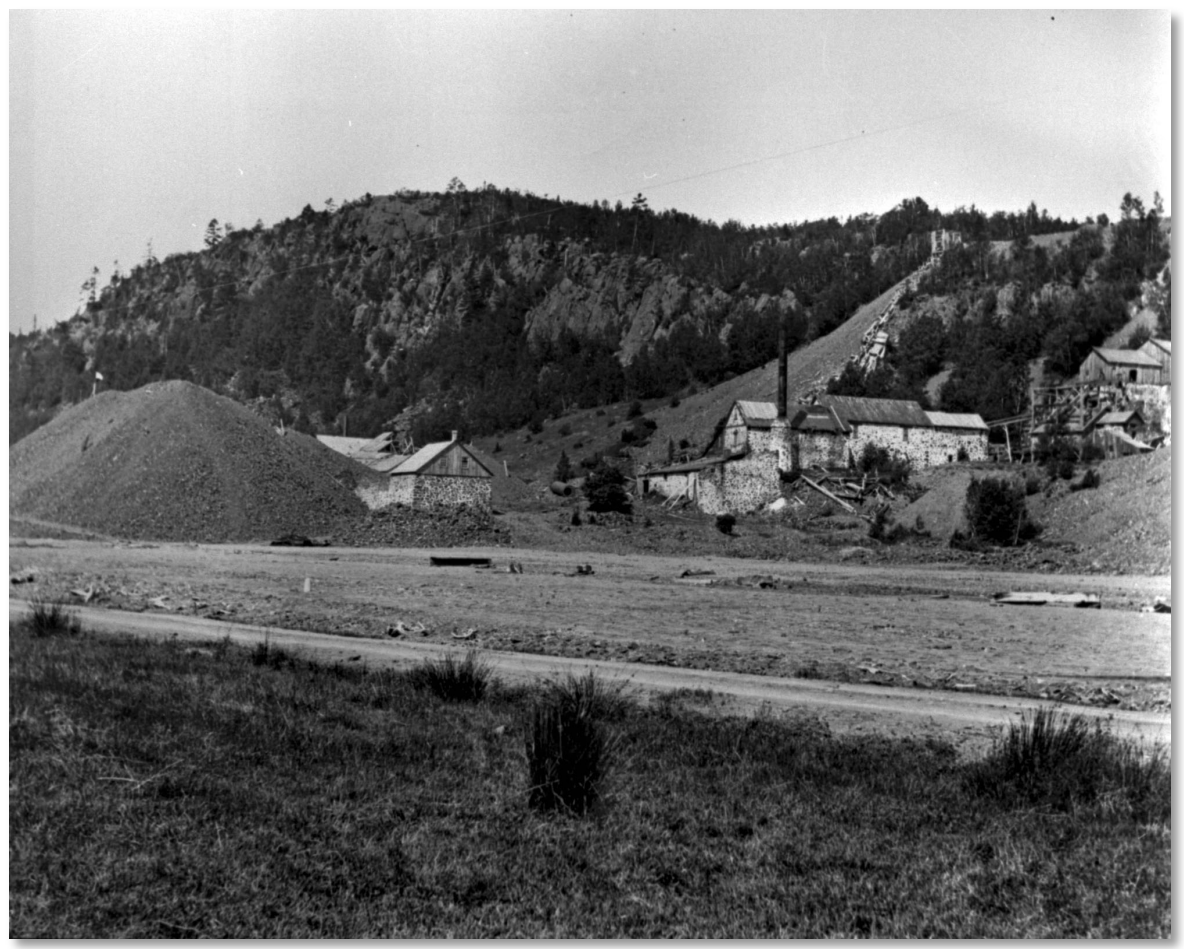

Fig. A-3. 


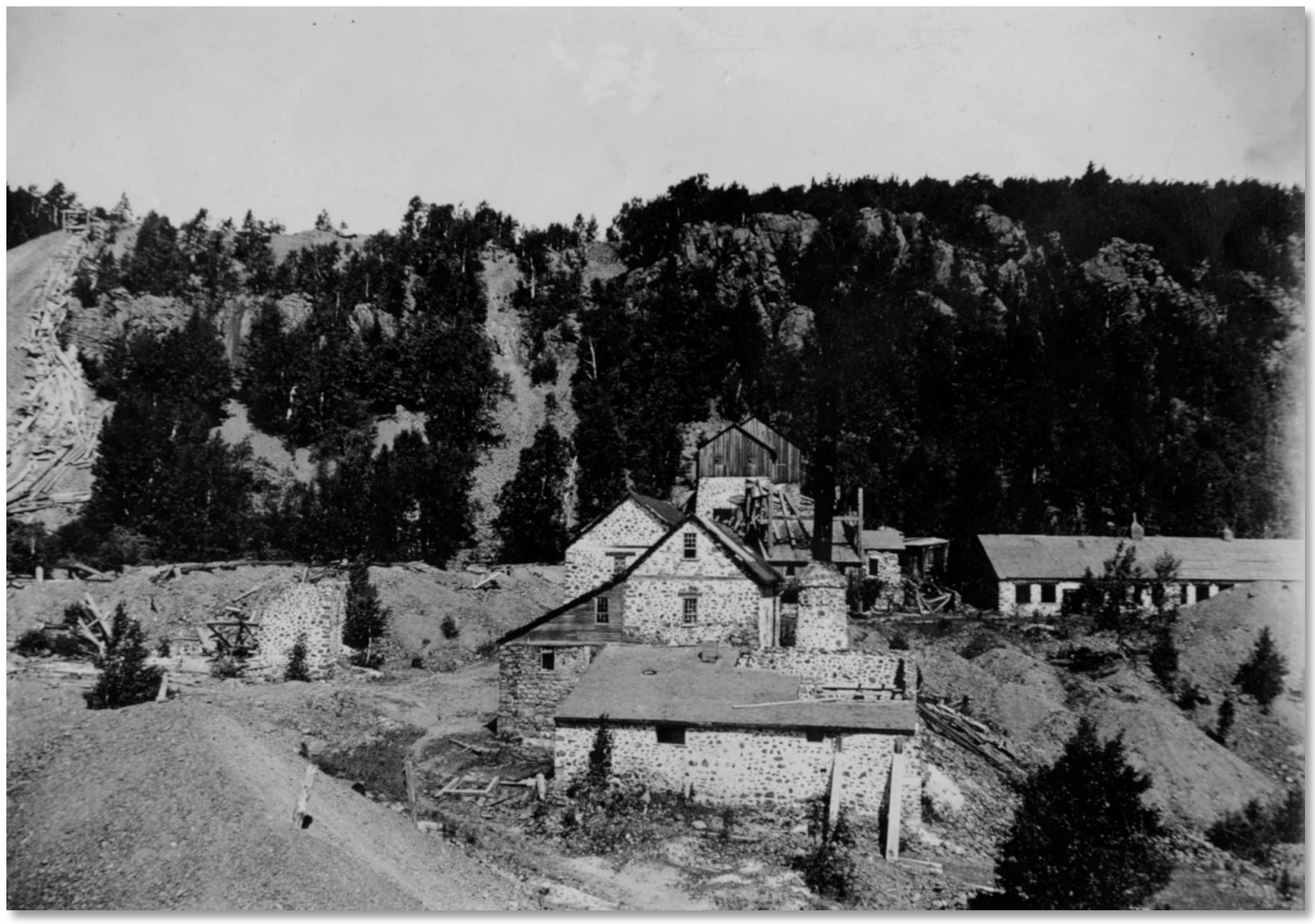

Fig. A-4. Above is view taken from the south of Avery Shaft surface plant circa 1900. From left to right are: eastern wall of mineral house, engine/hoist house with steam stack, Avery Shaft house in rear, and machine shop. (MS019-013-010-005, Brockway Photograph Collection. Michigan Tech Archives and Copper Country Historical Collections)

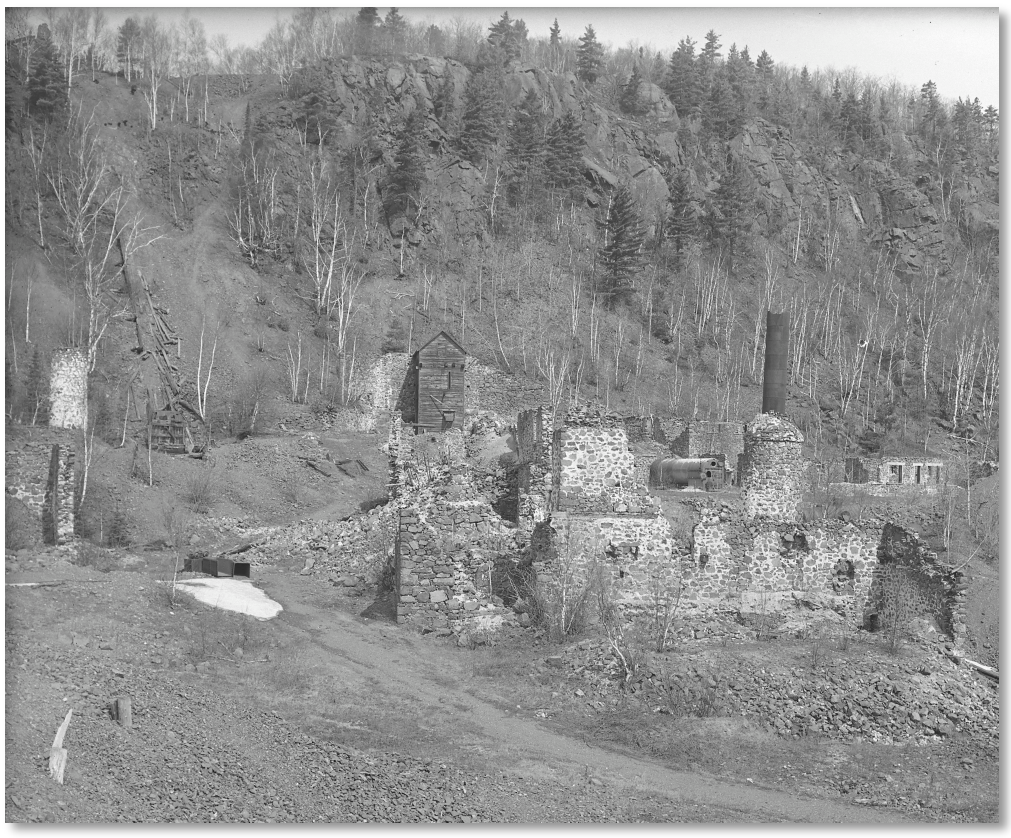

Fig. A-5. Another view of Avery Shaft surface plant, taken in 1923. Note the structures are for the most part in ruin. A new, smaller wooden shaft house built by the Tamarack Mining Company circa 1907 is situated over the Avery Shaft. Also visible are collapsed machine shop (far right), a boiler, the eastern wall of mineral house (far left), and a steam stack (also far left) that's purpose is at this time unknown. (MS042028-999-B-218C, Reeder Photographic Collection. Michigan Tech Archives and Copper Country Historical Collections) 


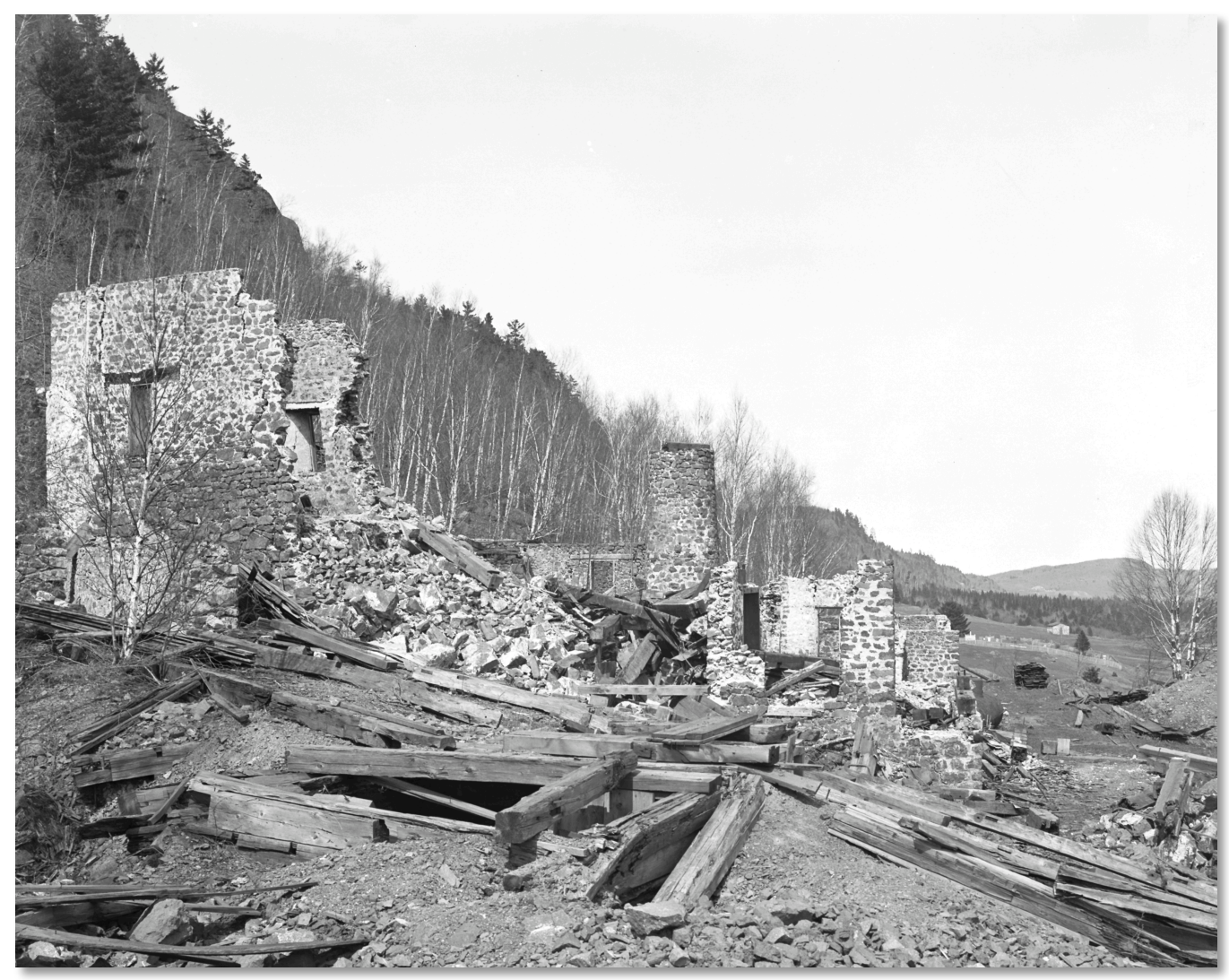

Fig. A-6. Above is view taken from the west of the collapsed Avery Shaft circa 1905. Two support walls are all that remain of the stone shaft house. At center is a steam stack probably associated with the pumps or man-engine due to its location within the Avery Shaft house complex. At far right a boiler is visible and beyond that in the distant background an intact powder house can be seen. (MS042-026-999-BB-35B, Reeder Photographic Collection. Michigan Tech Archives and Copper Country Historical Collections)

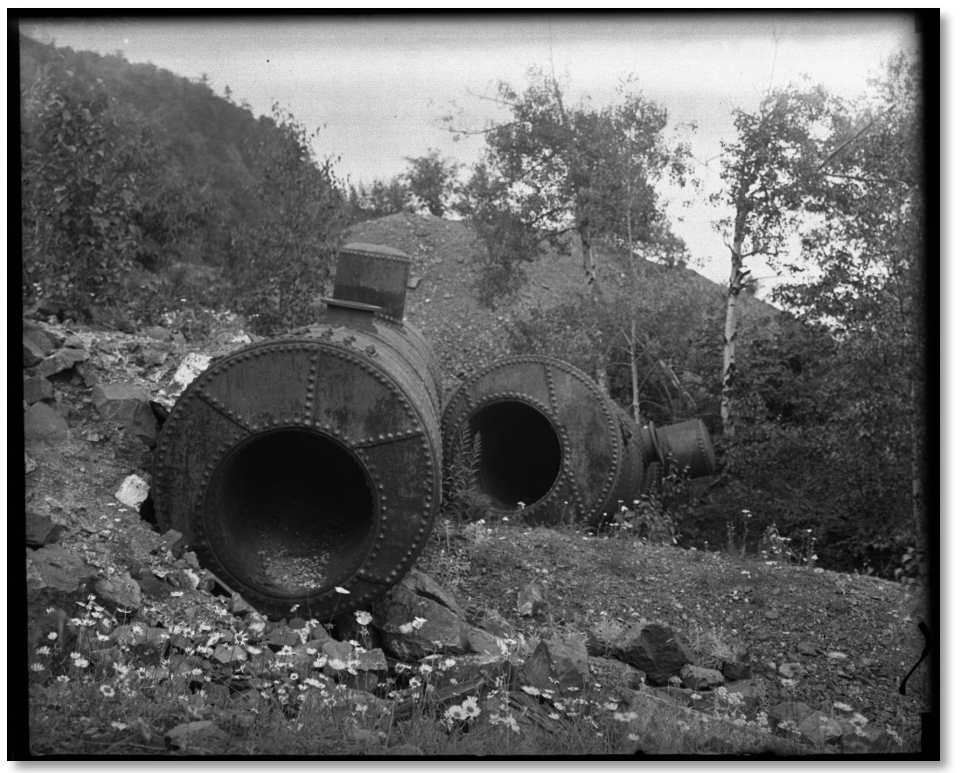

Fig. A-7. 1924 photo of two Cornish style single flue boilers found at Cliff. Possibly associated with the either the engine house, pumps, or manengine, these boilers rolled down into a depression off to the east of the engine house.

(MS042-050-999-U-847, Reeder Photograph Collection. Michigan Tech Archives and Copper Country Historical Collections) 


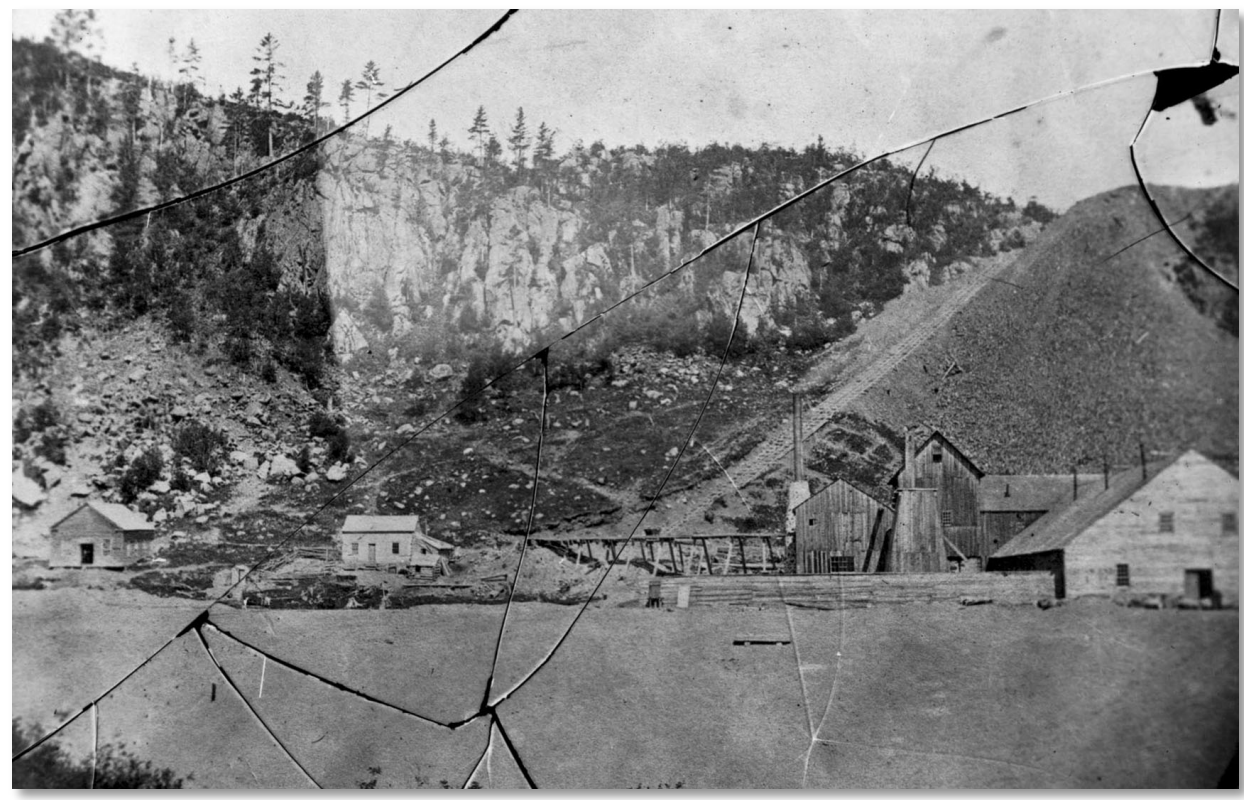

Fig. $A-8$. View from south of the stamp mill taken circa 1857. Engine house and steam stack are located behind the pyramid shaped structure (standing over an adit for pumping purposes). The stamp equipment are housed in the structure located behind the wash house (far right foreground). Note the launder projecting off of the washhouse running from right to left. In the upper background is the inclined tramway connecting the No. 3 shaft to the mill. (MTU Neg 00282, Roy Drier Photographic Collection. Michigan Tech Archives and Copper Country Historical Collections)

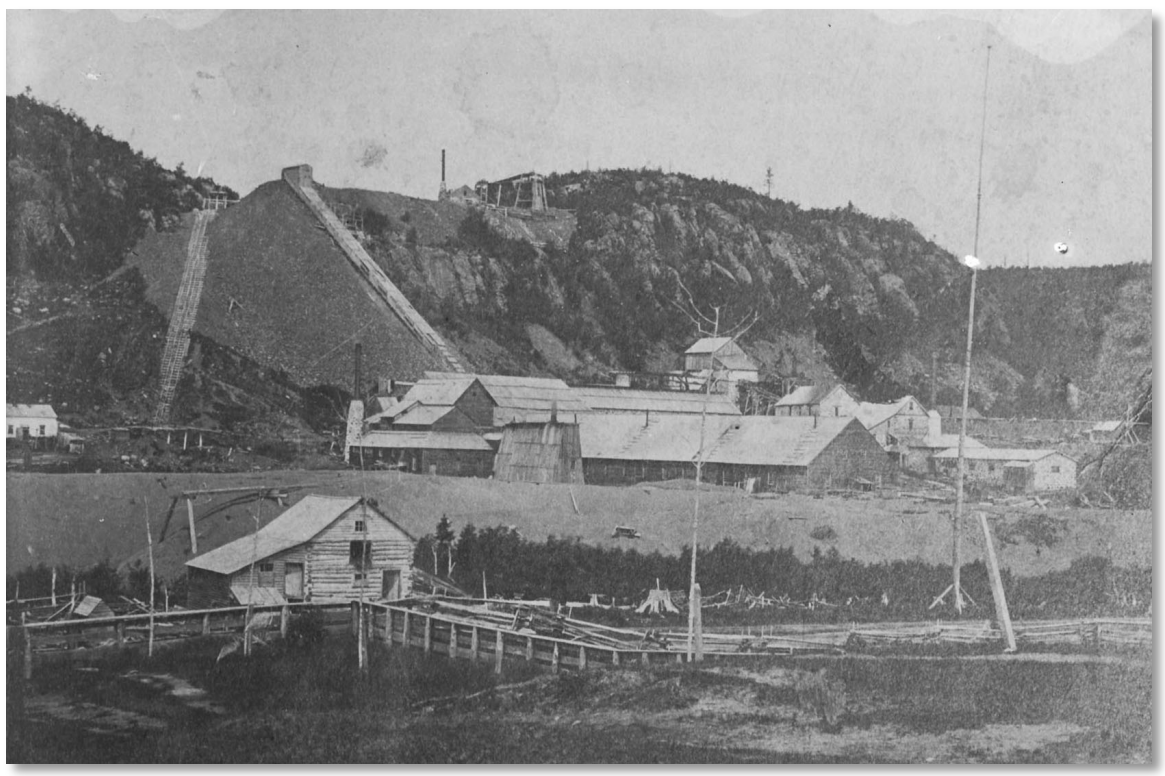

Fig. A-9. Another view of stamp mill and Avery Shaft surface plant, taken in 1862. Note the lengthened wash house (right foreground) and pyramid structure over possible adit. At the top of the bluff are the inclined tram (now in disuse) the covered rock chute connecting the Howe Shaft to the mill, and the No. 3 surface plant (top center-engine house and shaft house visible).(MS042-062-999 Z449, Reeder Photograph Collection. Michigan Tech Archives and Copper Country Historical Collections) 


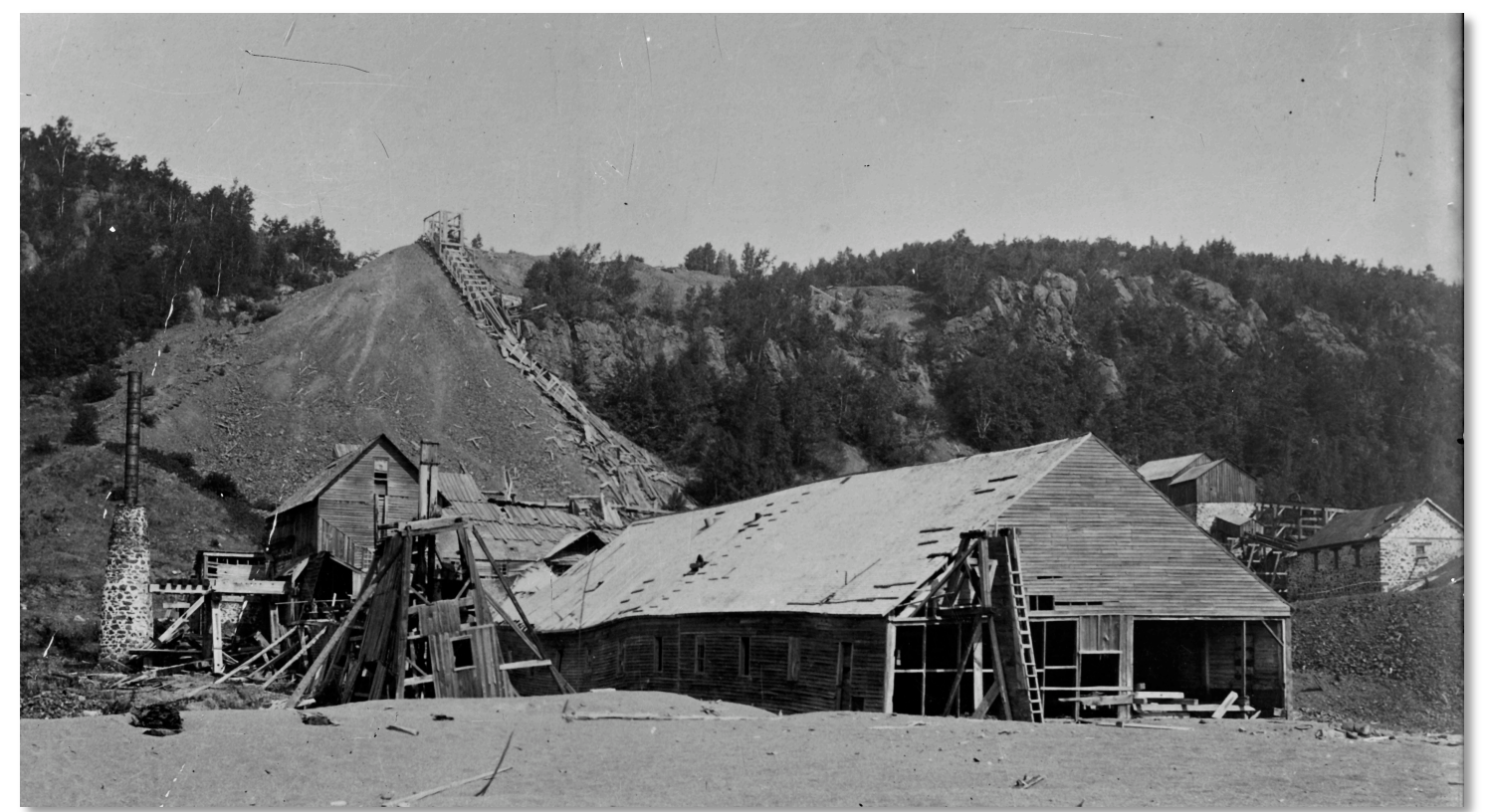

Fig. A-10. Detail of stamp mill and Avery Shaft surface plant, taken circa 1880's -1890's. Mill is in disuse at this point as washhouse, stamp room, mill engine room, and pyramid structure are all in a state of collapse. Inclined tram way has been removed and covered rock chute is also in state of ruin.

Avery Shaft and hoist house are visible at far right background. (MS042-040-999-T184, Reeder

Photographic Collection. Michigan Tech Archives and Copper Country Historical Collections)

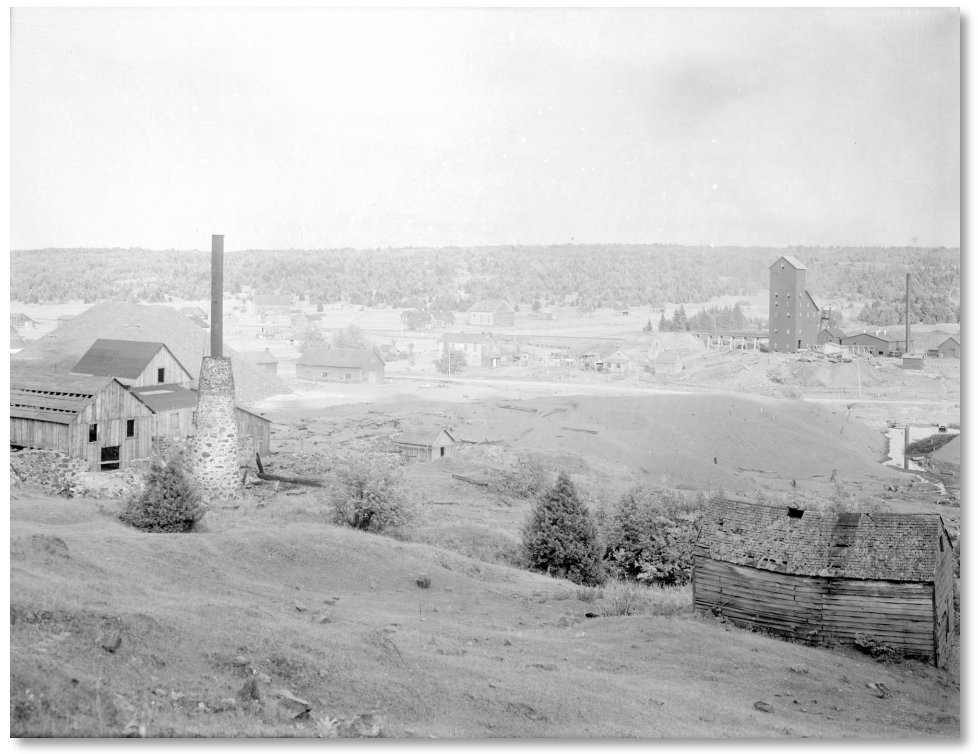

Fig. A-11. Stamp mill from the west, circa 1910. At this point the mill was in a state of ruin. The South Cliff No. 1

Shafthouse can be seen beyond the stamp sands at right. (MS042-036999-P030, Reeder Photographic Collection. Michigan Tech Archives and Copper Country Historical Collections. 


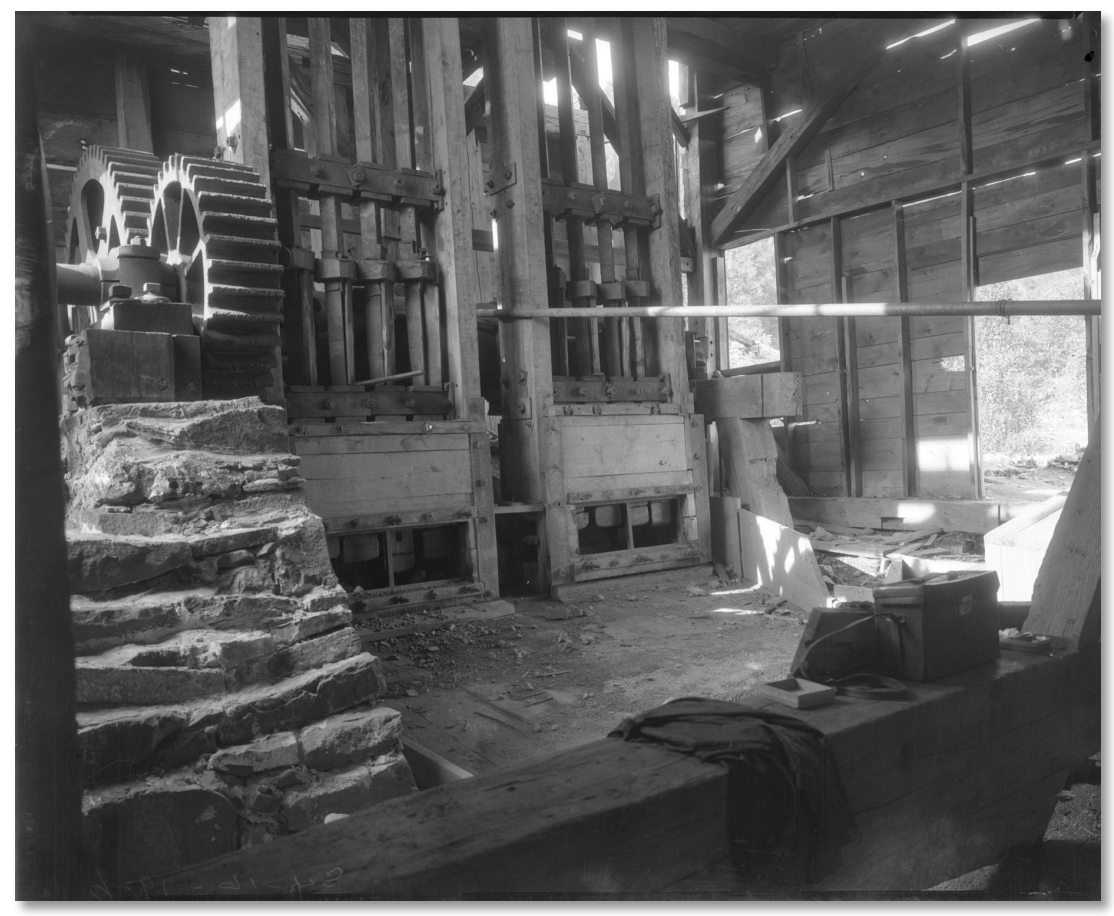

Fig. $A$-12. Interior view of stamp mill, 1926. Two batteries of Cornish style stamps are in use connected to a camshaft and associated gearing. Note photographer's camera case in foreground. (MS042-0157-999-W699, Reeder Photographic Collection. Michigan Tech Archives and Copper Country Historical Collections)

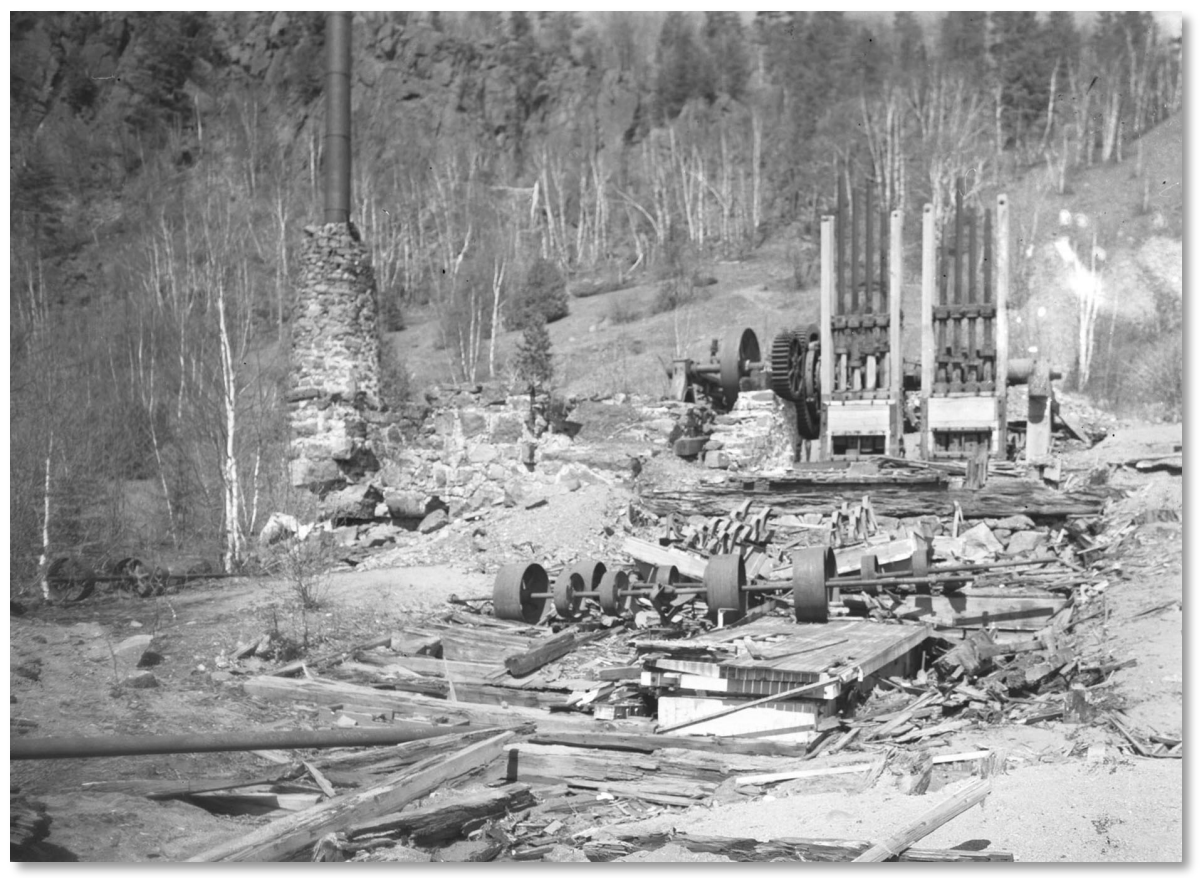

Fig. A-13. View of Warren's Mill after building was either torn or burnt down, 1927. Stamp batteries are still in place as is the camshaft and associated gearing. Line shafting once located overhead to operate the washing table are lying atop it. (MS042-058-999-W804B, Reeder Photographic Collection. Michigan Tech Archives and Copper Countrv Historical Collections) 


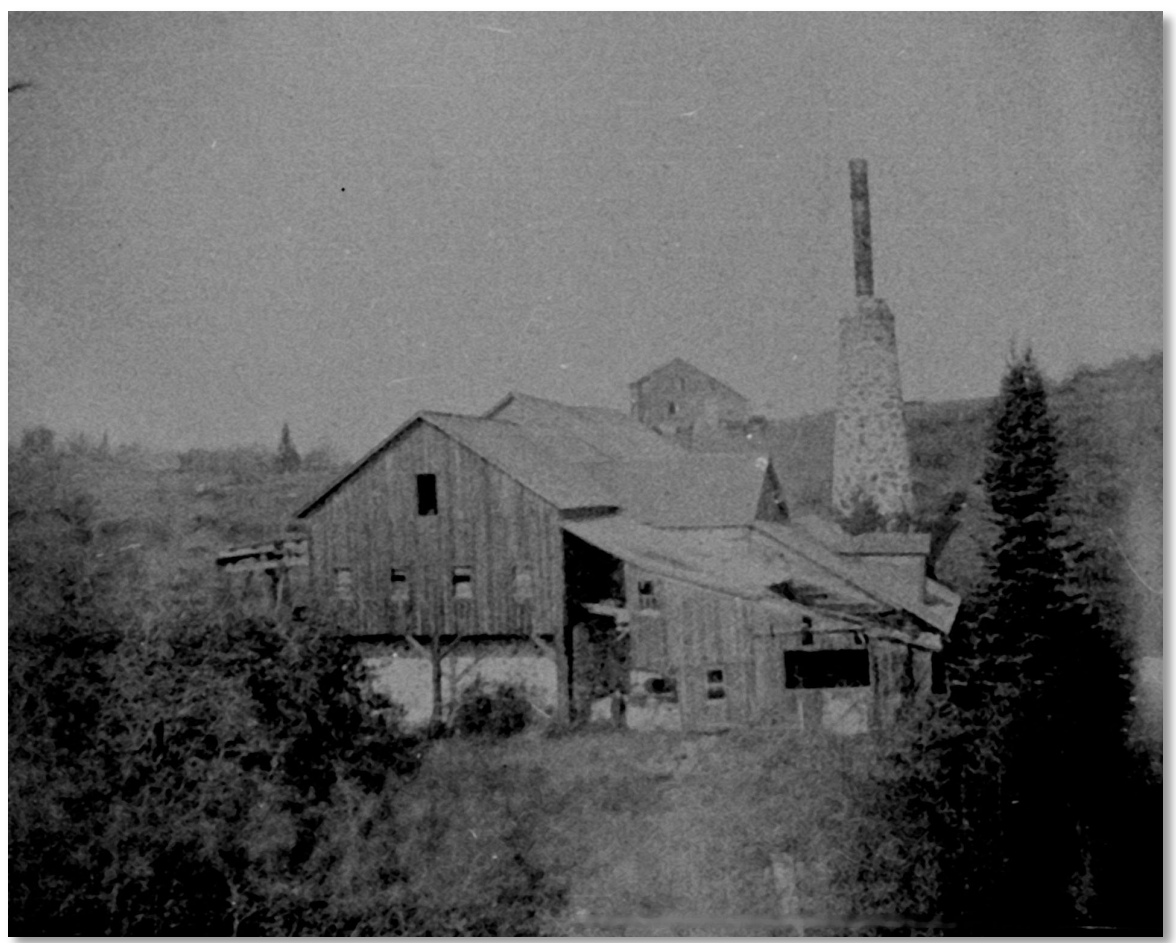

Figs. $A-14, A-15$. Views of No. 4 (Howe) Shaft engine and hoist house, circa 1860's-1890's. In above photo, taken from $\mathrm{SW}$, boilers were located in rear right of structure. Hoist located in left side of structure with possible connecting rods protruding from the building. In background can be seen one of two large boarding houses located NE of the Howe Shaft surface plant. The below photo (Fig. 15a) is taken from the east, with engine/hoist structure in foreground and kiln house at center right. At far right is the HoweShaft's shaft house where skips were used to raise ore and rock. Note rock piles fanning out at left side background. A large vertical rotative engine sat within the building just right of the steam stack. (MS025-002-024-ND33-5, Harry Reeder Photograph Collection. MTU Neg 03493, William S. Thomas Photographic Collection. Michigan Tech Archives and Copper Country Historical Collections)

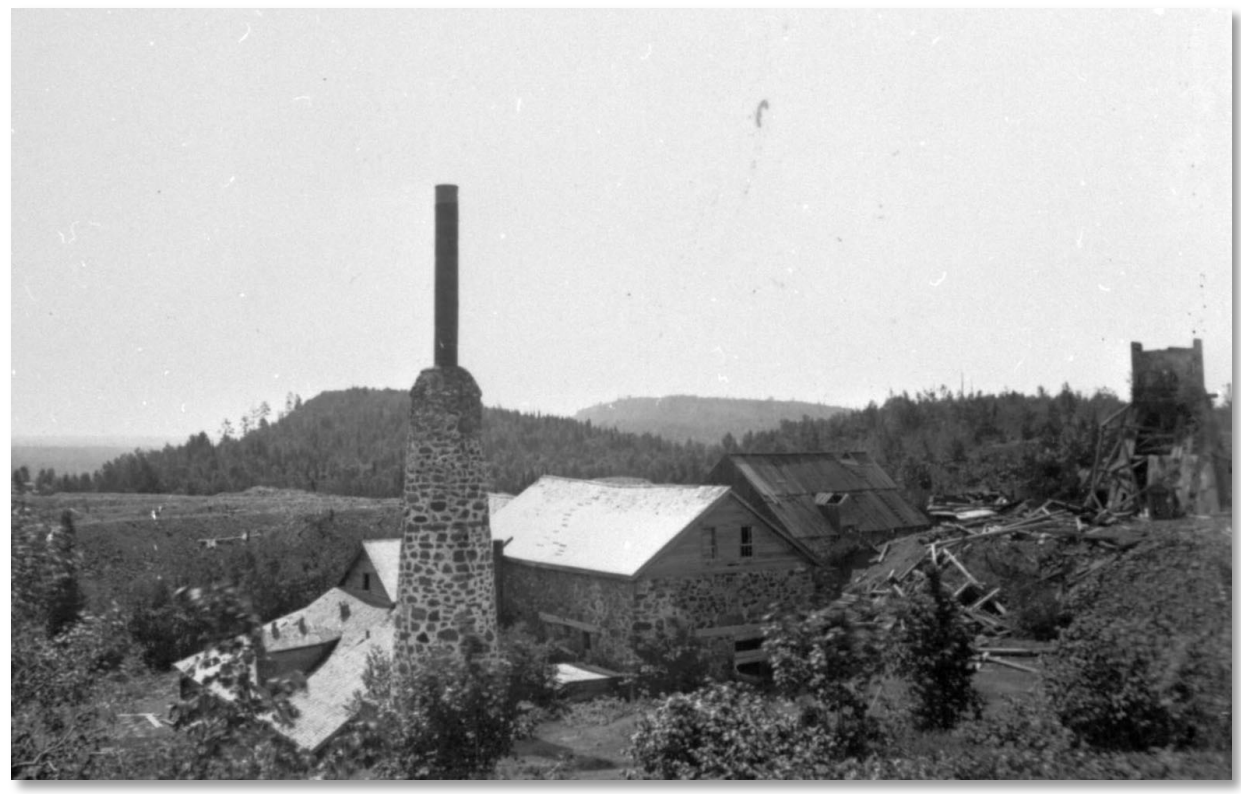




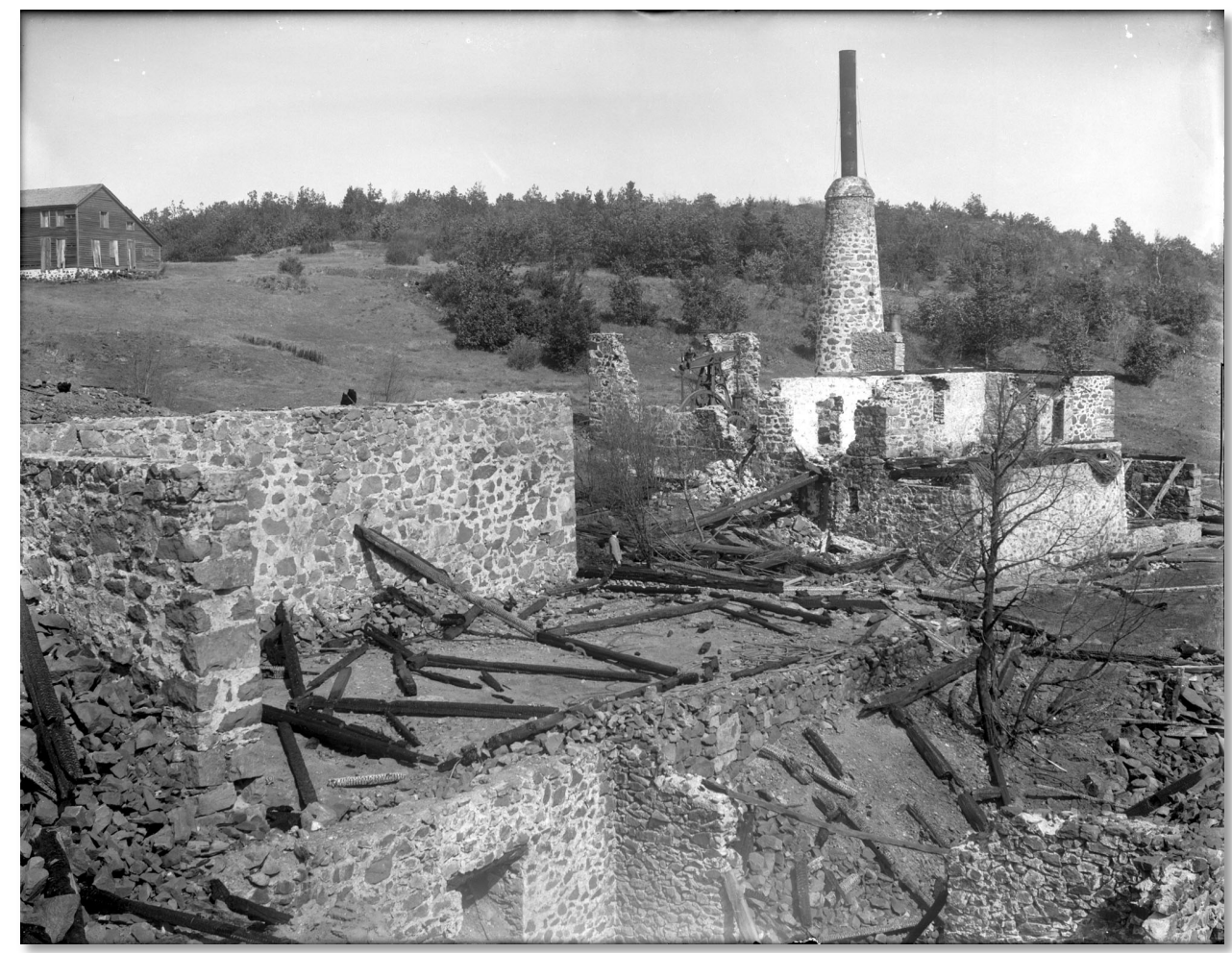

Fig. A-16. Howe Shaft's engine/hoist house in background with the kiln/rock house in foreground, circa 1900. Vertical rotative engine visible at center (with boy sitting atop it) while at far right can be seen coiled wire rope lying atop the hoist room's exterior wall. (MS042-036-P-008, Reeder Photographic Collection. Michigan Tech Archives and Copper Country Historical Collections)

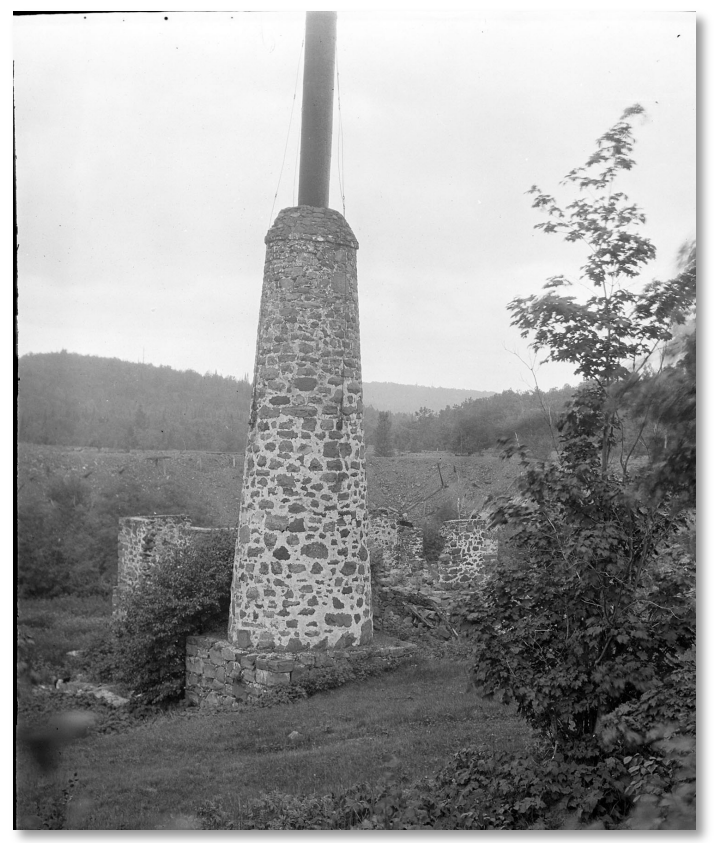

Fig. A-17. View from the east of the Howe Shaft's steam stack, 1912. Rock piles in the background are from the P\&BMC's period of operation. (MS-042-006-53-571, Reeder Photographic Collection. Michigan Tech Archives and Copper Country Historical Collections) 


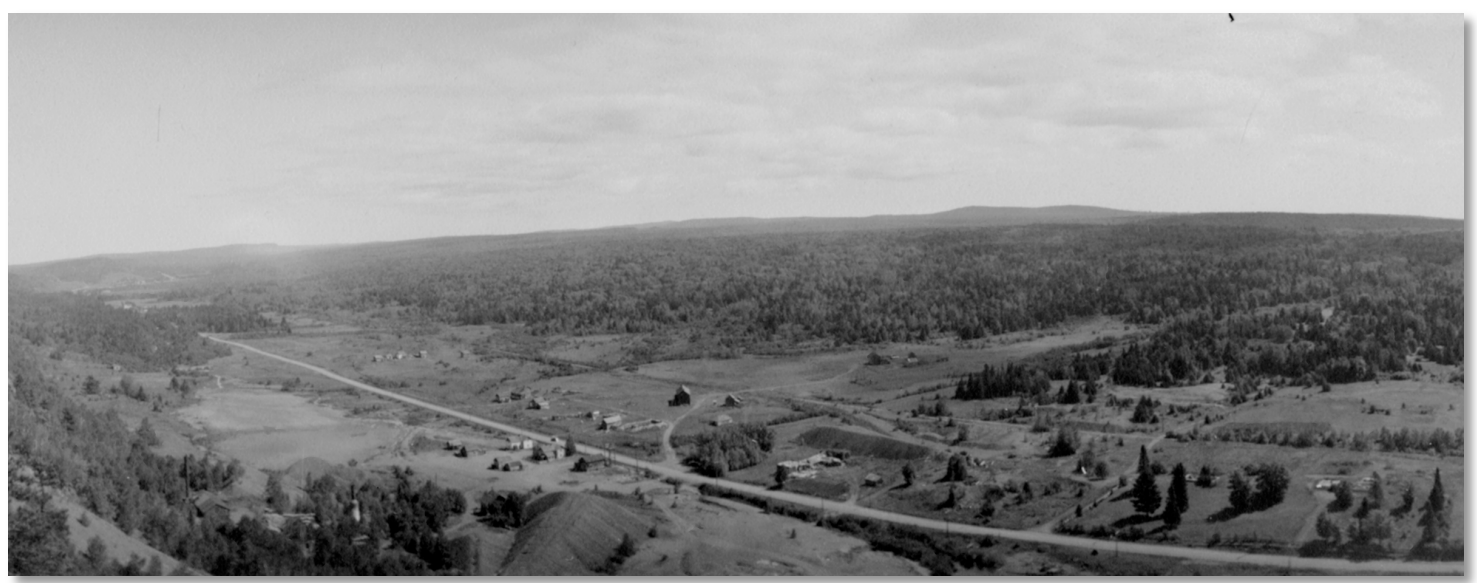

Fig. A-18. View taken from top of the bluff from the northwest of Clifton with rock piles in foreground, circa 1930's. (MS019-018-004-003, Brockway Photograph Collection. Michigan Tech Archives and Copper Country Historical Collections)

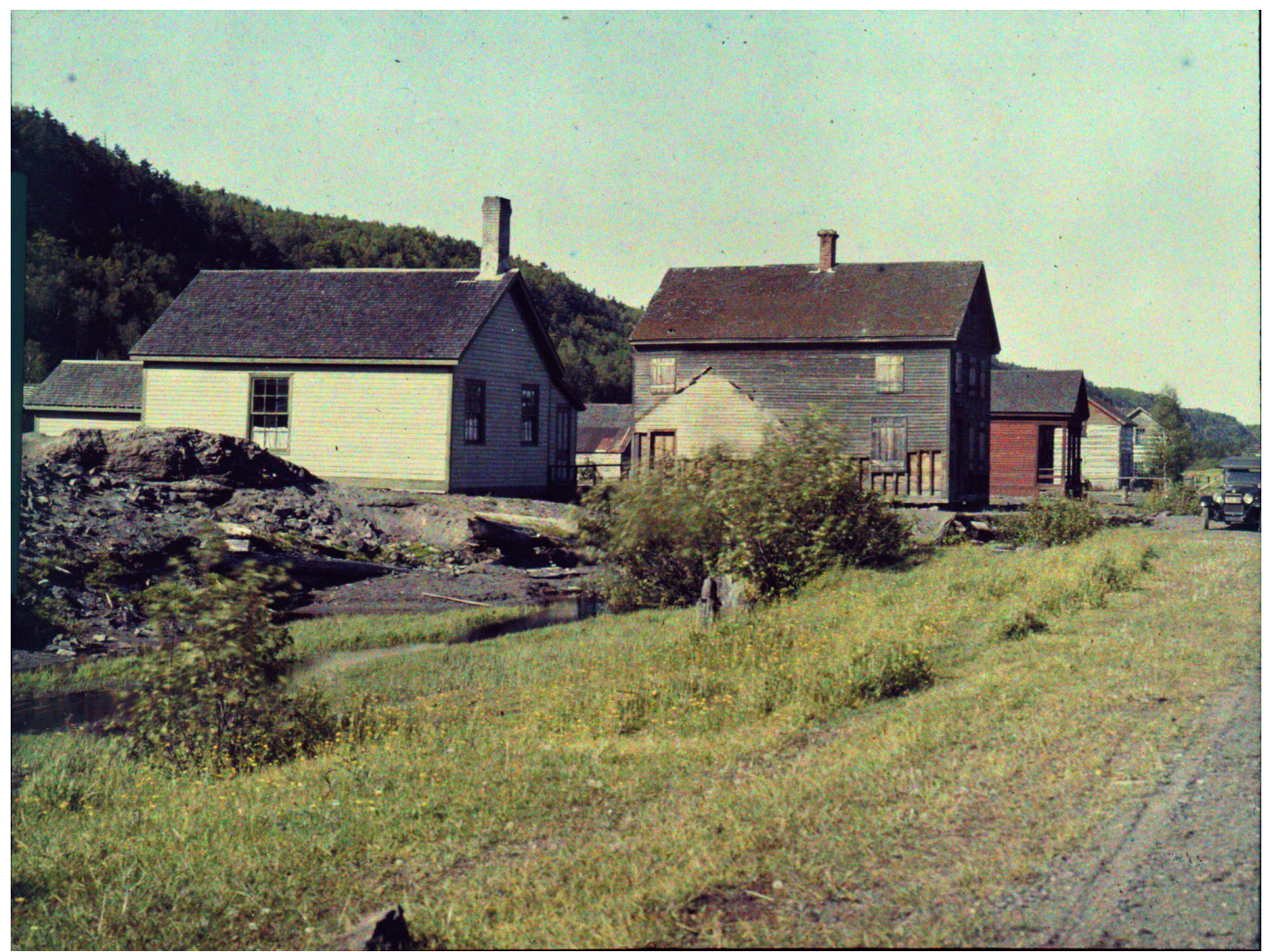

Fig. A-19. View from the west of the mine's school house (at left) and office building, 1925. Located just north of (present day) Cliff drive, physical traces of these structures are no longer present at the surface. Note the location of the west branch of the Eagle River, a natural boundary between the mine workings and Clifton. (MS042-008-053-950-14, Reeder Photograph Collection. Michigan Tech Archives and Copper Country Historical Collections) 


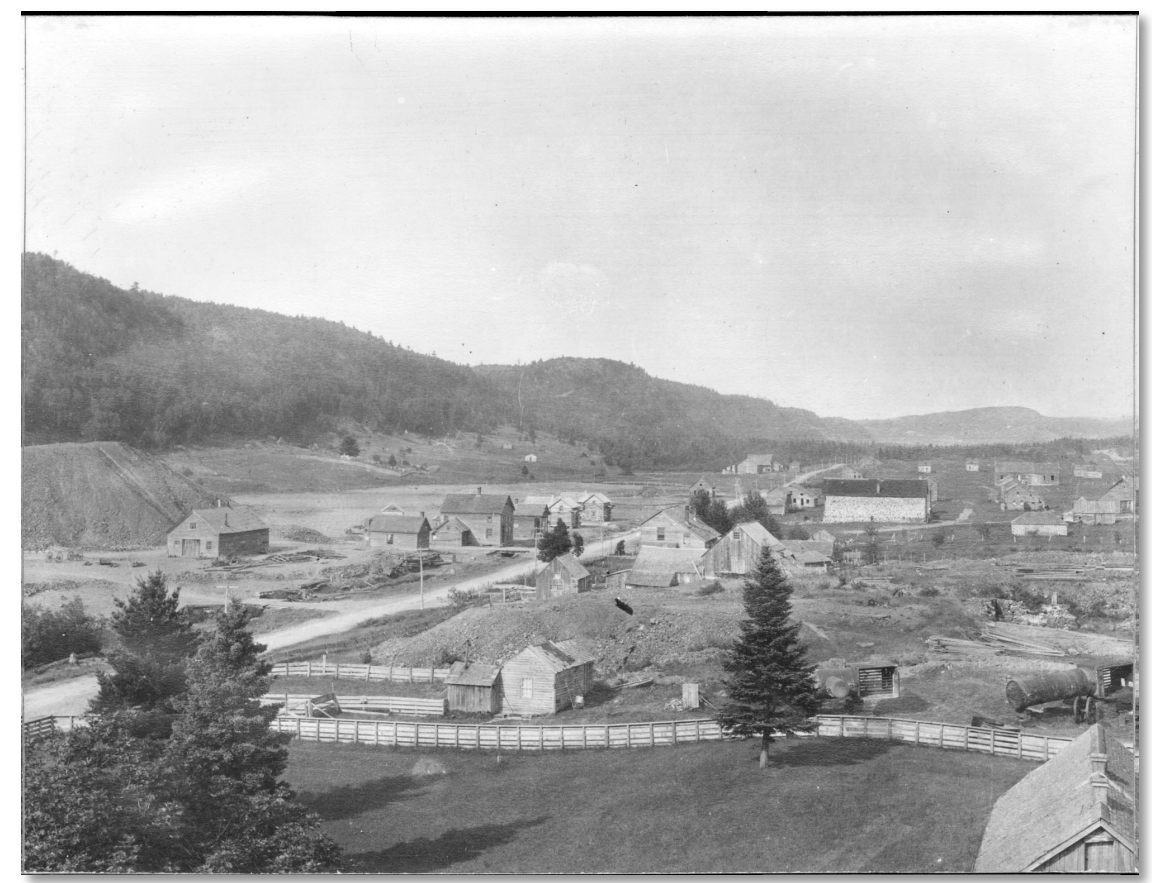

Fig. A-20. View of Clifton from the west, taken from the Superintendent's House, 1906. From left to right on left side of road are: carpentry shop, schoolhouse, mine office, and homes. On the right side of the road from left to right are: Agent's home, remains of South Cliff No. 1 Shaft, stone warehouse, homes, and an icehouse (in the foreground). (ACC-06016A-002. Michigan Tech Archives and Copper Country Historical Collections)

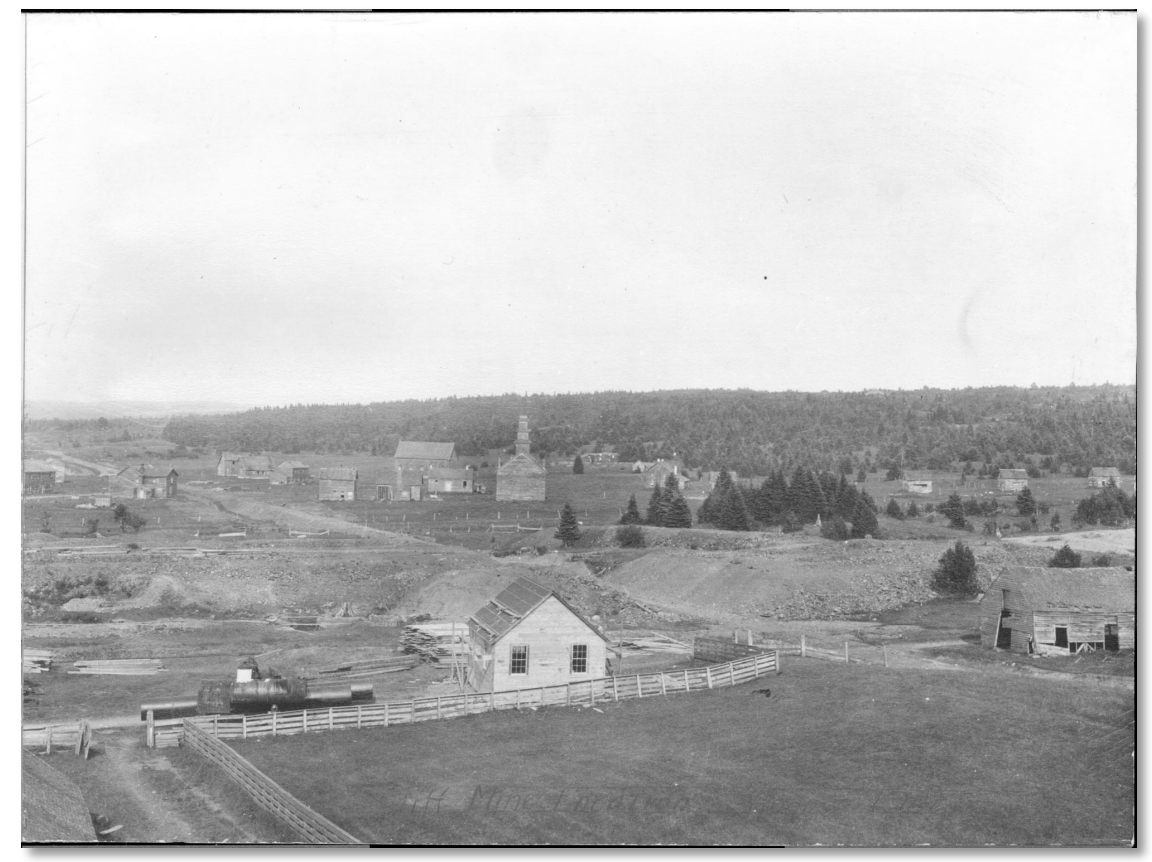

Fig. A-21. View of Clifton from the west, taken from the Superintendent's House, 1906. From left to right are: homes, Episcopal Church, Methodist Church, Catholic cemetery, and log cabin row. (ACC-06-016A-003. Michigan Tech Archives and Copper Country Historical Collections) 


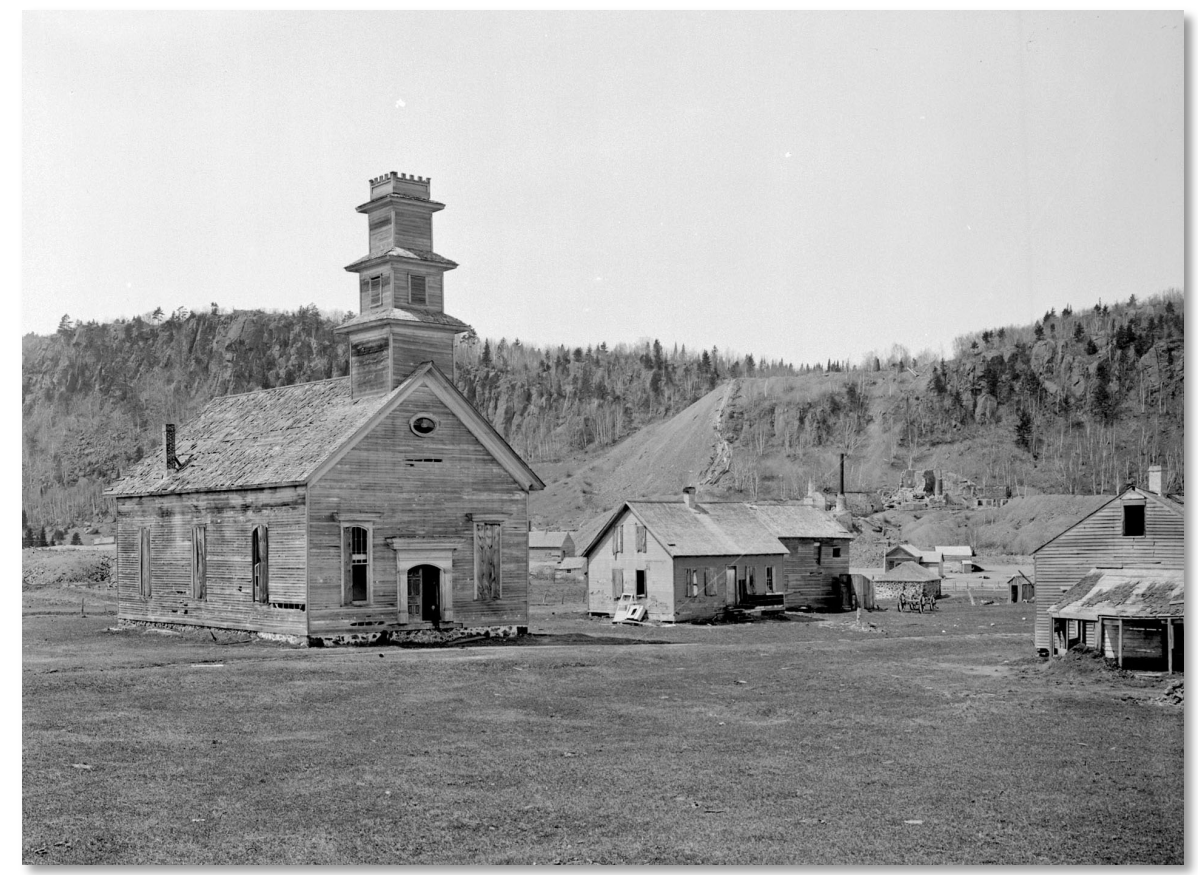

Fig. A-22. View from the south of the Methodist Church and various homes and barns, circa 1905. In the background can be seen the remains of the rock chute and Avery Shaft surface plant. Note that the No. 3 surface plant is no longer visible. (MS042-026-999-B45, Reeder Photograph Collection. Michigan Tech Archives and Copper Country Historical Collections)

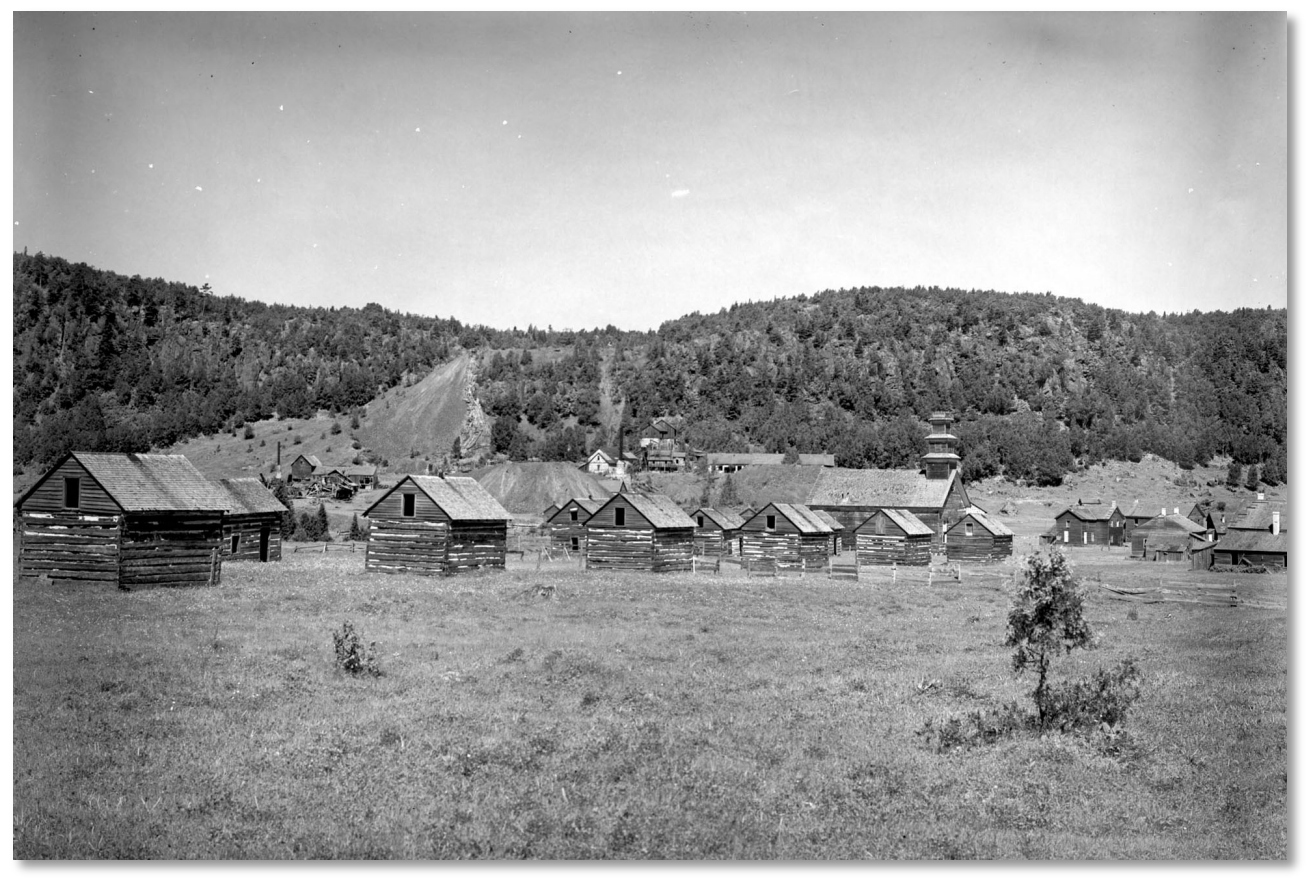

Fig. A-23. View from the south of "log cabin row" and Methodist Church, 1901. These log homes were worker's quarters, all built at the same period 9most likely late 1850's. (MS042-036-999-P-55, Reeder Photograph Collection. Michigan Tech Archives and Copper Country Historical Collections) 


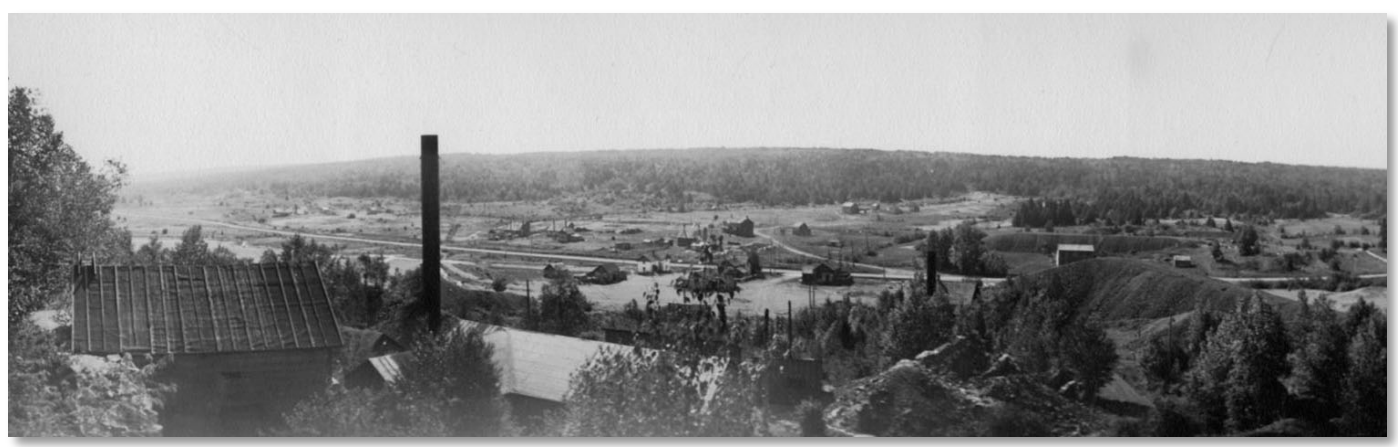

Fig. A-24. View from the northwest of the Avery Shaft surface plant and Clifton during the Calumet \& Hecla period of operation, circa 1930's. The new shaft house and C\&H's compressor building are visible along with the repurposed steam stack seen in Fig. A-6. (MS019-018-003-001, Brockway Photograph Collection. Michigan Tech Archives and Copper Country Historical Collections)

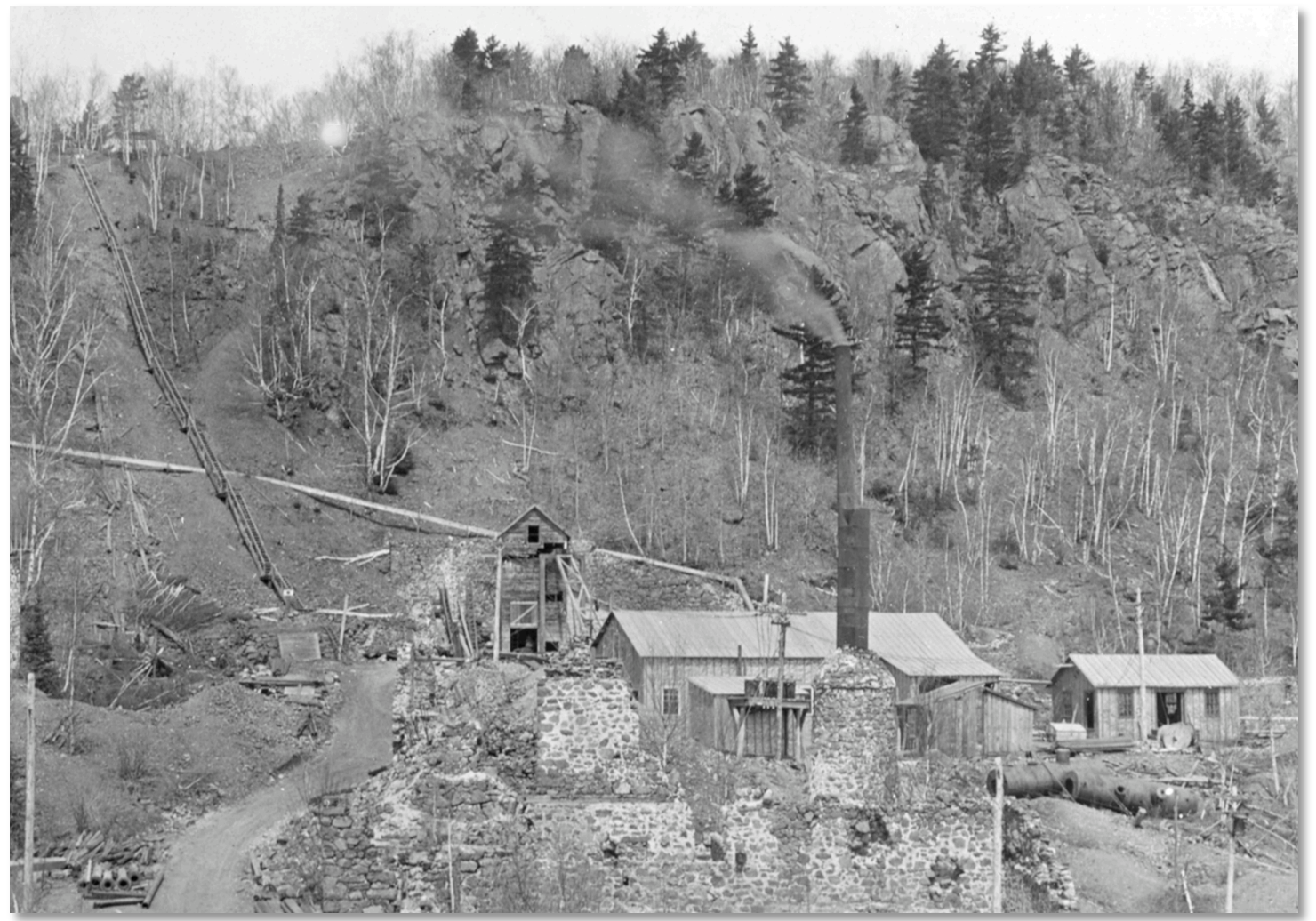

Fig. A-25. View from the south of the Avery Shaft surface plant during the Calumet \& Hecla period of operation, circa 1930's. The new shaft house and $C \& H$ 's compressor building are visible along with the repurposed steam stack (appears to come out of the engine house's steam stack) and boilers (before they fell down the hill) seen in Figs. $A-6 \& A-7$. Note the stairs leading up the bluff and passing by the No. 3 Shaft. (MTUo12-006-10-33, Mining Engineering Photograph Collection. Michigan Tech Archives and Copper Country Historical Collections) 


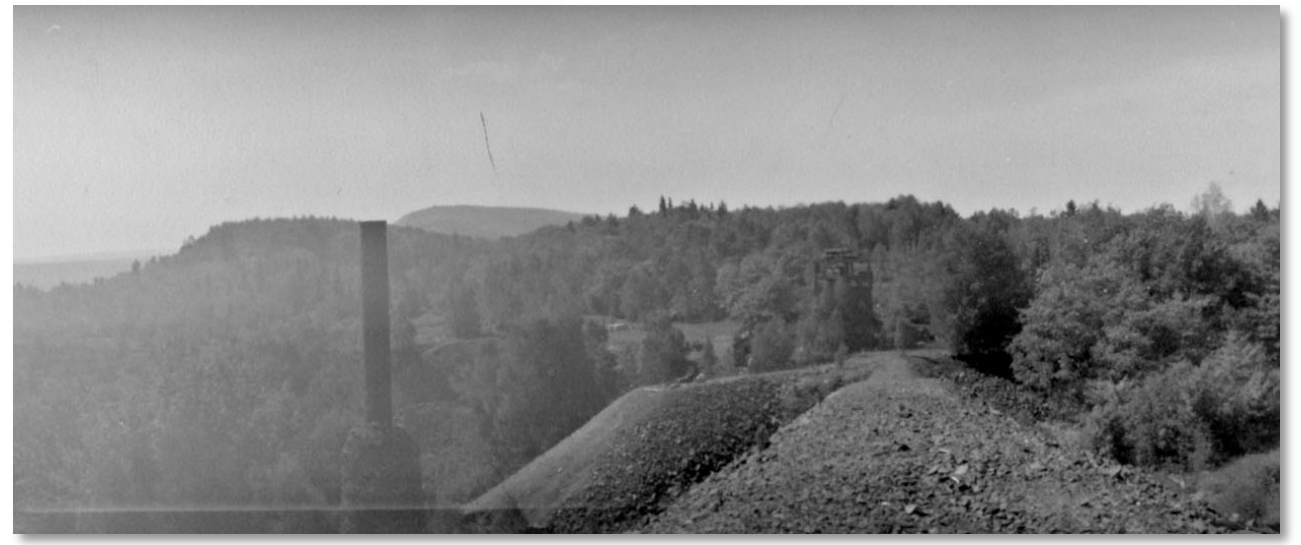

Fig. A-26. View from the east of Howe Shaft surface plant, circa 1930's. The steam stack and shaft house ruins are all that is visible of the plant at this point (during the Calumet \& Hecla period of operation). The rock pile the photographer is standing upon was likely created by C\&H during their exploratory work at the Howe Shaft. (MS019-018-003-002, Brockway Photograph Collection. Michigan Tech Archives and Copper Country Historical Collections)

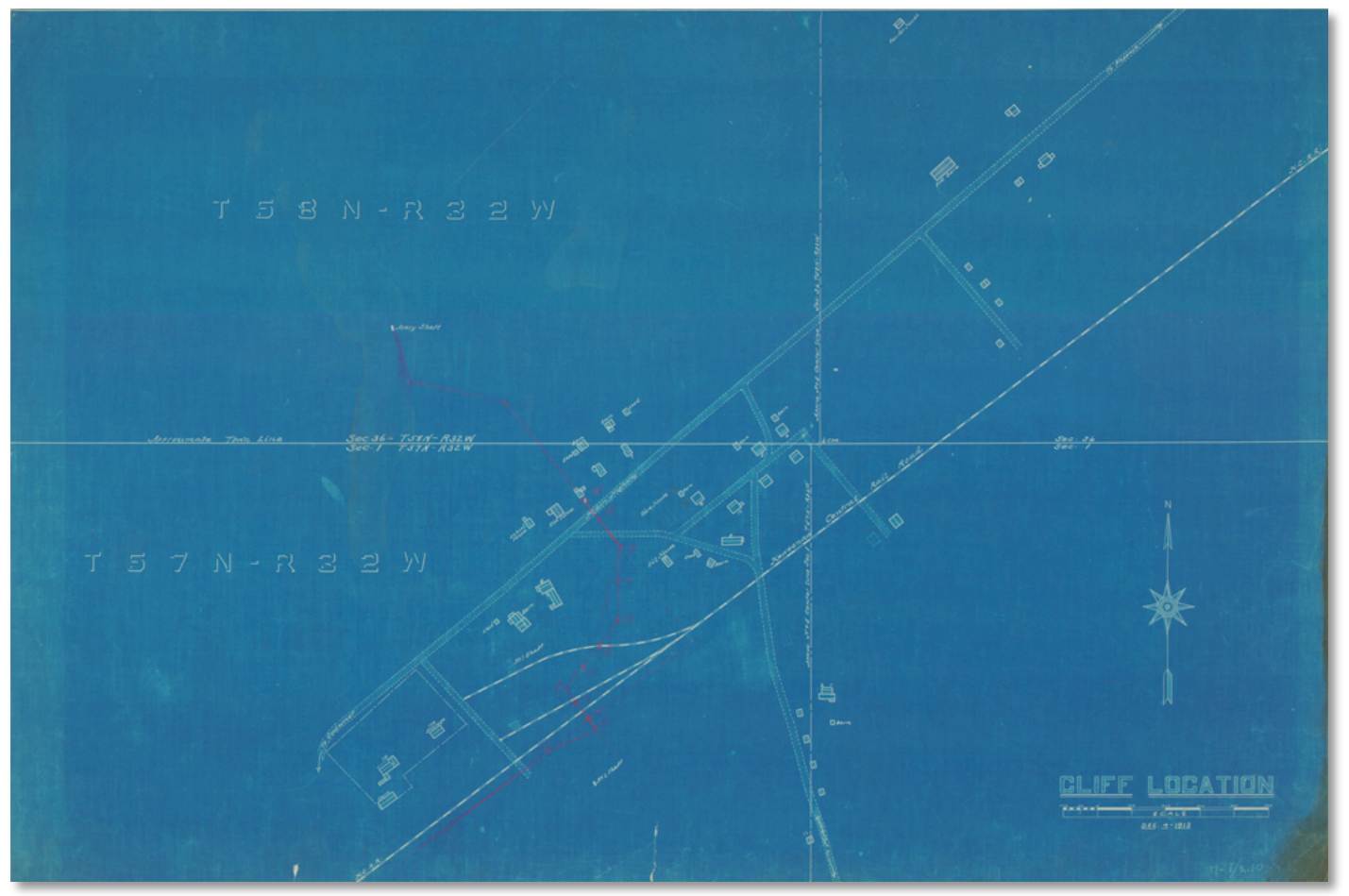

Fig. A-27. Cliff Location, Dec. 4, 1913. This map was made just after Calumet \& Hecla Mining Company took over operations at the Cliff Mine. From lower left to upper right are: the Superintendent's House, the Agent's House, the schoolhouse, mine office, and various homes. Log cabin row can be seen at bottom center. (Map-27B-1913. C\&H Oversize Map Collection. Michigan Tech Archives and Copper Country Historical Collections) 


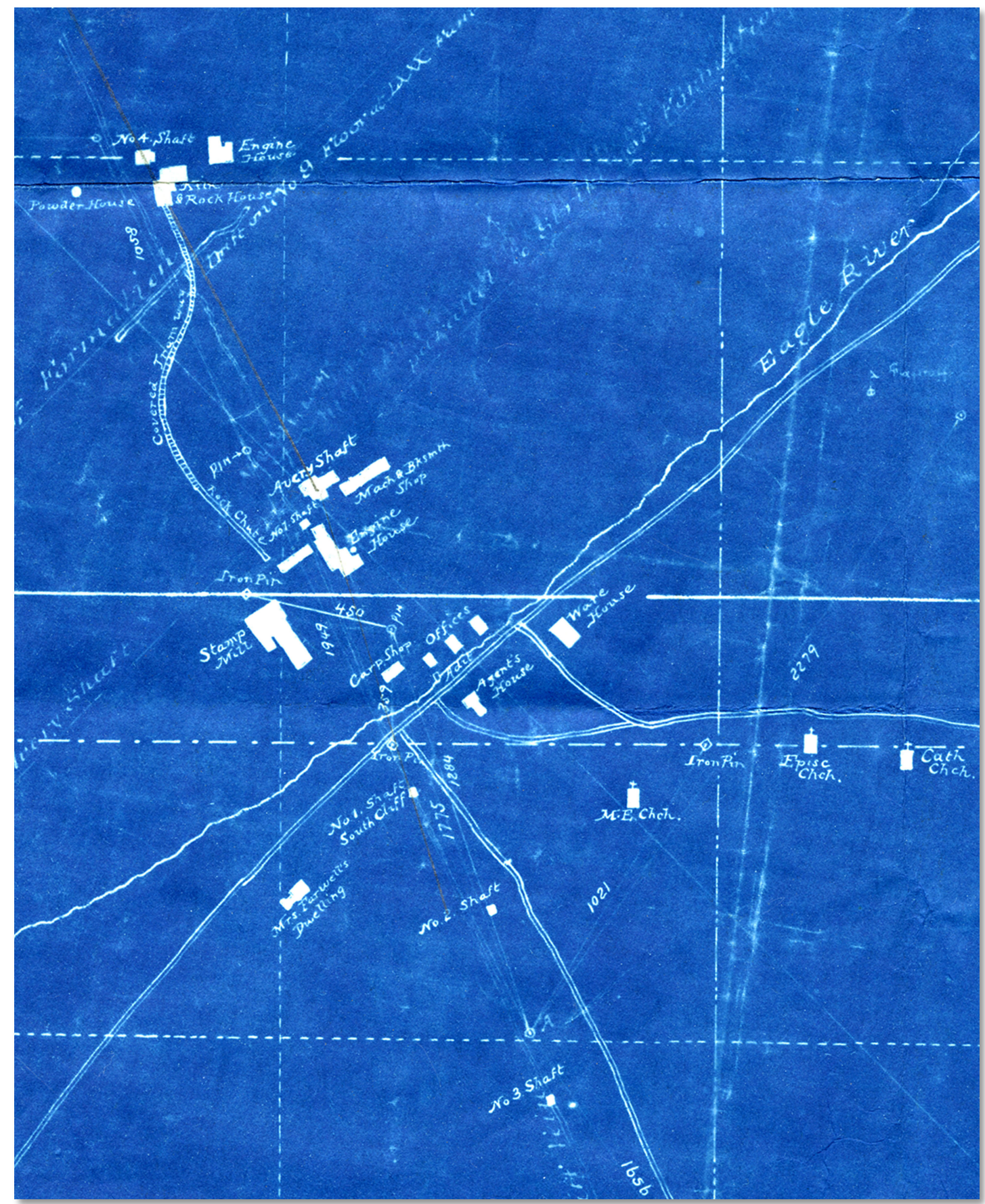

Fig. A-28. Detail of a blueprint map of the Cliff Mine and Clifton, circa 1870's-1880's. This image was the primary document used in determining operational zones for the field season. The road running from lower left to upper right divides the mine site from the town site. Just to the NW of the road are the carpentry shop, the school, and mine offices. NW of those are: the stamp mill, mineral house, engine house, No. 1 Shaft, Avery Shaft, and machine shop. Moving north are: the rock chute, covered tram way, kiln house, powder house, No. 4 (Howe) Shaft, and engine house. To the SE of the road are the Superintendent's House (labeled Mrs. Farwell's here), South Cliff No.'s 1, 2 and 3 Shafts, the Agent's House, warehouse, and the Methodist,

Episcopal, and Catholic churches. (MAP 29B-20A-01-Detail, Oversize Map Collection. Michigan Tech Archives and Copper Country Historical Collections) 


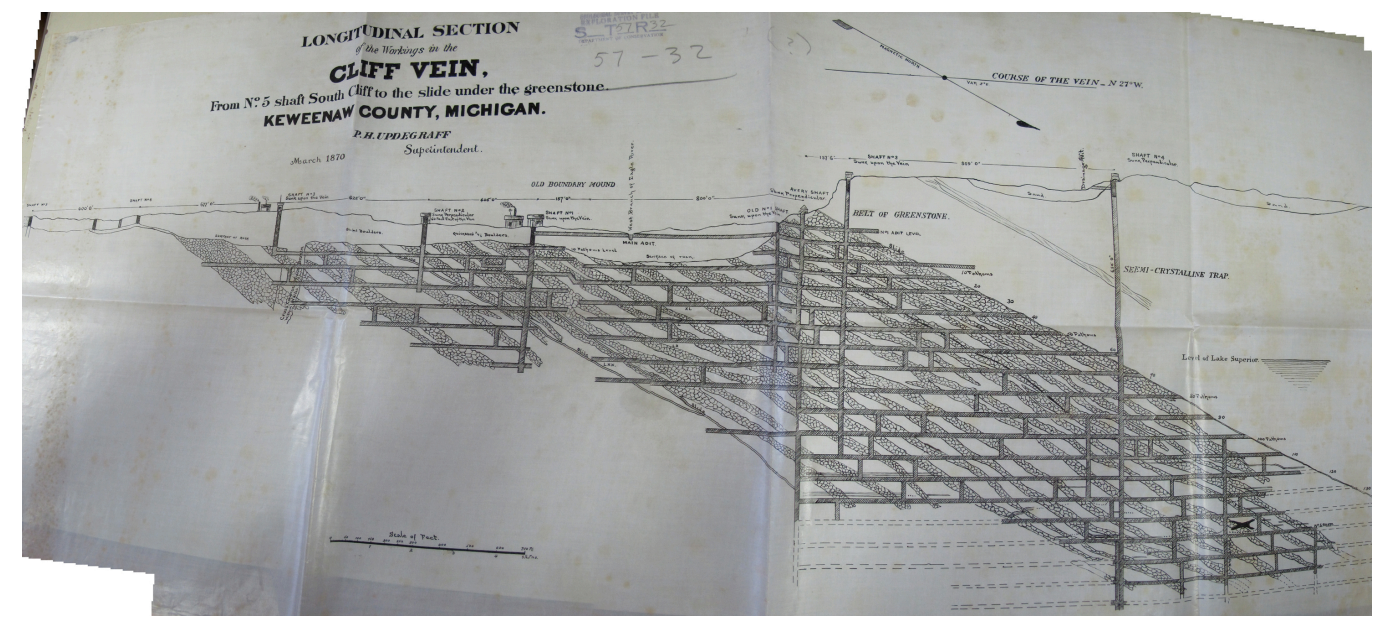

Fig. A-29. Longitudinal Section of the Workings of the Cliff Vein. From No. 5 South Cliff to the slide under the greenstone. Keweenaw County, Michigan. P.H. Updegraff,

Superintendent. March, 1870. This map shows the extent of the mine's underground workings at about the time that work was stopped by the P\&BMC. Of note are the bands of amygdaloid floors running parallel to the slide as well as the lone connection between the workings of the Cliff and South Cliff. (Image courtesy of the Michigan Department of Natural Resources and Environment's Core Sample Repository in Marquette, MI.) 


\section{Appendix B:}

\section{List of Features}

\begin{tabular}{|c|c|c|c|c|c|c|}
\hline $\begin{array}{l}\text { O.Z. } \\
\text { Code }\end{array}$ & Feature Name & $\begin{array}{c}\text { Feature } \\
\#\end{array}$ & Feature Description & Function & $\begin{array}{l}\text { Building } \\
\text { Material }\end{array}$ & Footprint \\
\hline SM & Stamp Room & 100 & $\begin{array}{l}\text { Area where stamps were } \\
\text { housed. No foundations } \\
\text { present. Bolts and machine } \\
\text { mounts present. }\end{array}$ & Industrial & & $8 \times 10 \mathrm{~m}$ \\
\hline SM & Wash House & 101 & $\begin{array}{l}\text { Area where ore is washed } \\
\text { and separated from rock. Jig } \\
\text { table present. eastern stone } \\
\text { foundation wall present. }\end{array}$ & Industrial & Stone & $\begin{array}{l}\text { approx. } \\
30 \times 18 \mathrm{~m}\end{array}$ \\
\hline SM & $\begin{array}{l}\text { Boiler/Engine } \\
\text { Room }\end{array}$ & 102 & $\begin{array}{l}\text { Area housing steam boilers. } \\
\text { Rectangular stone foundation } \\
\text { with raised central walkway. } \\
\text { Iron rod near NE corner } \\
\text { along with coal pile. }\end{array}$ & Industrial & Stone & $23.5 \times 9.5 \mathrm{~m}$ \\
\hline SM & Pass House & 103 & $\begin{array}{l}\text { Room where rock was } \\
\text { stored and dumped into the } \\
\text { stamp machinery }\end{array}$ & Industrial & & $10 \times 8 \mathrm{~m}$ \\
\hline SM & $\begin{array}{l}\text { Raised Foundation } \\
\text { Room }\end{array}$ & 104 & $\begin{array}{l}\text { Raised platform with stone } \\
\text { floor. Possible location of } \\
\text { steam engine for stamp mill. } \\
\text { Machine mounts present. }\end{array}$ & Industrial & Stone/Brick & $16 \times 14 \mathrm{~m}$ \\
\hline SM & Steam Stack & 105 & Stamp mill's steam stack. & Industrial & Stone & $3.1 \mathrm{~m}$ diameter \\
\hline SM & Sump Adit & 107 & $\begin{array}{l}\text { Depression just off the SW } \\
\text { corner of stamp mill. }\end{array}$ & Landsape & Earth & $2 \times 2.2 \mathrm{~m}$ \\
\hline SM & Jig Table & 108 & $\begin{array}{l}\text { Wood remains of tables base } \\
\text { with iron nails. }\end{array}$ & Industrial & Wood & Unknown \\
\hline SM & Inclined Tramway & 109 & $\begin{array}{l}\text { Depression where tramway } \\
\text { once laid. }\end{array}$ & Transportation & Earth & \\
\hline SM & Wood Beam & 110 & $\begin{array}{l}\text { Large wood beam lying over } \\
\text { stone foundation. }\end{array}$ & Industrial & Wood & Unknown \\
\hline MY & Mineral Shed & $\begin{array}{c}200201 \\
202\end{array}$ & $\begin{array}{l}\text { Warehouse. Stone } \\
\text { foundations and walls } \\
\text { present. }\end{array}$ & Industrial & Stone & $44.91 \times 10.8 \mathrm{~m}$ \\
\hline MY & Tram Way & 203 & $\begin{array}{l}\text { Earthen mound leading from } \\
\text { No. } 1 \text { Shaft area towards } \\
\text { stamp mill. }\end{array}$ & Transportation & Earth & $60 \mathrm{~m}$ \\
\hline MY & $\begin{array}{l}\text { Waste Rock } \\
\text { Terrace }\end{array}$ & 206 & $\begin{array}{l}\text { Flat area filled with waste } \\
\text { rock to create a platform } \\
\text { working area. }\end{array}$ & Landscape & Stone & Unknown \\
\hline MY & Rock Chute & 208 & $\begin{array}{l}\text { Ephemeral remains of } \\
\text { wooden rock chute trailing } \\
\text { down the bluff. }\end{array}$ & Industrial & $\mathrm{N} / \mathrm{A}$ & $75 \mathrm{~m}$ \\
\hline $\mathrm{AV}$ & Dryhouse? & 300 & $\begin{array}{l}\text { Possible Dryhouse, location } \\
\text { where miners changed into } \\
\text { work clothes. Stone walls } \\
\text { present. Evidence of adaptive } \\
\text { reuse (later used as a barn). }\end{array}$ & Industrial & Stone & $16.67 \times 9.31 \mathrm{~m}$ \\
\hline AV & Boiler Remains & 301 & $\begin{array}{l}\text { Two pieces of a steam } \\
\text { boiler. }\end{array}$ & Industrial & Metal & Unknown \\
\hline $\mathrm{AV}$ & $\begin{array}{l}\text { Stone Foundations } \\
\text { below hill }\end{array}$ & 302 & $\begin{array}{l}\text { Dilapidated walls in hard to } \\
\text { distinguidh layout. }\end{array}$ & Habitation & Stone & Unknown \\
\hline $\mathrm{AV}$ & $\begin{array}{l}\text { Engine House } \\
\text { Support Buildings }\end{array}$ & 303 & $\begin{array}{l}\text { Terraced area to the south of } \\
\text { the Avery engine house. } \\
\text { Once a support building for } \\
\text { the e.h. }\end{array}$ & Industrial & Stone & $11.3 \times 6.5 \mathrm{~m}$ \\
\hline
\end{tabular}




\section{Appendix B:}

\section{List of Features}

\begin{tabular}{|c|c|c|c|c|c|c|}
\hline AV & Engine House & 304 & $\begin{array}{l}\text { Stone foundations of the } \\
\text { Avery Engine House. First } \\
\text { location of steam machinery } \\
\text { at the mine. Walls and } \\
\text { machine mounts present. }\end{array}$ & Industrial & Stone & $22.1 \times 18 \mathrm{~m}$ \\
\hline $\mathrm{AV}$ & $\begin{array}{l}\text { Steam Stack } \\
\text { (Engine House) }\end{array}$ & 305 & $\begin{array}{l}\text { Engine house's steam stack. } \\
\text { Metal top of stack still } \\
\text { present. }\end{array}$ & Industrial & Stone/Metal & $3.1 \mathrm{~m}$ diameter \\
\hline $\mathrm{AV}$ & Hoist House & 306 & $\begin{array}{l}\text { Stone foundations and walls } \\
\text { collapsed in on themselves } \\
\text { located to the north of the } \\
\text { Avery engine house. } \\
\text { Probably hoist house where } \\
\text { winding drum would be } \\
\text { located. }\end{array}$ & Industrial & Stone & $21 \times 9.2 \mathrm{~m}$ \\
\hline $\mathrm{AV}$ & \#1 Shaft & 307 & $\begin{array}{l}\text { Behind the Mineral Shed } \\
\text { between the trenches, in } \\
\text { front of the Mineral Shed. }\end{array}$ & Industrial & Earth & Unknown \\
\hline $\mathrm{AV}$ & \#2 Shaft & 308 & $\begin{array}{l}\text { Circular depression in the } \\
\text { gound west of the horse } \\
\text { whim platform. }\end{array}$ & Industrial & Earth & $\begin{array}{l}3.3 \mathrm{~m} \text { in } \\
\text { diameter }\end{array}$ \\
\hline $\mathrm{AV}$ & Avery Shaft & 309 & $\begin{array}{l}\text { Part of a hillside of collapsed } \\
\text { rock with a metal pipe } \\
\text { entering the slope to the east. }\end{array}$ & Industrial & Earth & Unknown \\
\hline $\mathrm{AV}$ & $\begin{array}{l}\text { Unknown Possible } \\
\text { Change House }\end{array}$ & 310 & $\begin{array}{l}\text { Rectangular stone structure, } \\
\text { next to long stone wall. }\end{array}$ & Industrial & Stone & $8 \times 6.6 \mathrm{~m}$ \\
\hline $\mathrm{AV}$ & $\begin{array}{l}\text { C\&H Era } \\
\text { Foundations }\end{array}$ & 311 & $\begin{array}{l}2 \text { concrete pads with multiple } \\
\text { metal bolts on them and a } \\
\text { third structure to the east } \\
\text { which is built into the } \\
\text { ground. }\end{array}$ & Industrial & $\begin{array}{l}\text { Concrete, } \\
\text { Brick, Stone }\end{array}$ & $\begin{array}{c}6.8 \times 3.6 \mathrm{~m} \\
4.9 \times 4.2 \mathrm{~m} \\
4 \times 2.4 \mathrm{~m} \\
\end{array}$ \\
\hline $\mathrm{AV}$ & $\begin{array}{l}\text { Steam Stack/Flue } \\
\text { (Boiler Room) }\end{array}$ & 312 & $\begin{array}{l}\text { Steam stack and flue, located } \\
\text { by the C\&H period concrete } \\
\text { pads, flue has a large metal } \\
\text { plate in it. Large stone wall } \\
\text { going to the west and east, } \\
\text { the stack is sandwiched by } \\
\text { walls. }\end{array}$ & Industrial & Stone & $19.7 \times 8.9 \mathrm{~m}$ \\
\hline $\mathrm{AV}$ & $\begin{array}{l}\text { Man Engine } \\
\text { Room? }\end{array}$ & 313 & $\begin{array}{l}\text { Man engine room, earthen } \\
\text { area with stone walls, } \\
\text { surrounded by barbed wire. }\end{array}$ & Industrial & Stone & \\
\hline AV & Pump House & 314 & $\begin{array}{l}\text { Stone structure near } \mathrm{C} \& \mathrm{H} \\
\text { foundations. }\end{array}$ & Industrial & Stone & $8.5 \times 4 \mathrm{~m}$ \\
\hline $\mathrm{AV}$ & Machine Shop & 315 & $\begin{array}{l}\text { Stone foundations of three } \\
\text { room machine shop where } \\
\text { tool manufacture took place. } \\
\text { Evidence of looting is } \\
\text { widespread. }\end{array}$ & Industrial & Stone & $28.36 \times 8.34 \mathrm{~m}$ \\
\hline $\mathrm{AV}$ & Waste Rock Piles & 316 & $\begin{array}{l}\text { Oval mound of waste rock } \\
\text { covered with some } \\
\text { vegetation }\end{array}$ & Industrial & Rock & $10 \times 5.5 \mathrm{~m}$ \\
\hline $\mathrm{AV}$ & Tram Ways & 317 & & & & \\
\hline $\mathrm{AV}$ & $\begin{array}{l}\text { Horse Whim } \\
\text { Platform }\end{array}$ & 318 & $\begin{array}{l}\text { Earthen terrace held by a } \\
\text { stone wall, near the Avery } \\
\text { shaft. }\end{array}$ & Industrial & Stone & Approx. $8 \mathrm{x} 4 \mathrm{~m}$ \\
\hline AV & $\begin{array}{l}\text { Mystery Steam } \\
\text { Stack/Flue }\end{array}$ & 319 & $\begin{array}{l}\text { Lower portion of steam stack } \\
\text { located near shaft number } 2 \text {. }\end{array}$ & Industrial & Stone & $2.7 \mathrm{~m}$ diameter \\
\hline $\mathrm{AV}$ & $\begin{array}{l}\text { Waste Rock } \\
\text { Terrace }\end{array}$ & 320 & $\begin{array}{l}\text { Possible horse whim } \\
\text { platform. }\end{array}$ & Landscape & Stone/Earth & Unknown \\
\hline
\end{tabular}




\section{Appendix B:}

\section{List of Features}

\begin{tabular}{|c|c|c|c|c|c|c|}
\hline N3 & Engine House & 400 & $\begin{array}{l}\text { No. } 3 \text { Shaft Engine House. } \\
\text { Stone foundations present. } \\
\text { Machine mounts (possible } \\
\text { hoist drum) located on SE } \\
\text { corner of structure. }\end{array}$ & Industrial & Stone & $14.75 \times 7.5 \mathrm{~m}$ \\
\hline N3 & Steam Stack & 401 & $\begin{array}{l}\text { No. } 3 \text { Shaft Engine House's } \\
\text { steam stack. }\end{array}$ & Industrial & Stone & $2.5 \mathrm{~m}$ diameter \\
\hline N3 & No. 3 Shaft & 402 & $\begin{array}{l}\text { Large depression located at } \\
\text { edge of the bluff. Iron pipe } \\
\text { emerging from it. }\end{array}$ & Landscape & Earth & Unknown \\
\hline N3 & Early Drift in bluff & 403 & $\begin{array}{l}\text { Waste rock and chiseled } \\
\text { area of bluff face where early } \\
\text { diggings occurred. }\end{array}$ & Landscape & Earth & Unknown \\
\hline N3 & $\begin{array}{l}\text { C\&H Era } \\
\text { Foundations }\end{array}$ & 404 & $\begin{array}{l}\text { Three cement slabs at edge } \\
\text { of bluff used to anchor } \\
\text { electric lines? }\end{array}$ & Industrial & Cement & Unknown \\
\hline N3 & Trench & 405 & $\begin{array}{l}\text { Trench to provide water for } \\
\text { No. } 3 \text { engine house }\end{array}$ & Landscape & Earth & $35 \mathrm{~m}$ \\
\hline N3 & $\begin{array}{l}\text { Prospecting } \\
\text { Diggings }\end{array}$ & 407 & $\begin{array}{l}\text { Possible prospecting shaft } \\
\text { near covered tramway }\end{array}$ & Landscape & Earth & $3 \times 3 m$ \\
\hline N3 & Wagon Road & 408 & $\begin{array}{l}\text { Level path leading from } \\
\text { logging road south. }\end{array}$ & Transporation & Earth & $70 \mathrm{~m}$ \\
\hline $\mathrm{N} 4$ & Engine House & 500 & $\begin{array}{l}\text { large poor walls. East wall } \\
\text { extends to the NW. Platform } \\
\text { near east wall. }\end{array}$ & Industrial & Stone & $15.7 \times 12.5 \mathrm{~m}$ \\
\hline $\mathrm{N} 4$ & Steam Stack & 501 & $\begin{array}{l}\text { No. } 4 \text { stack partially covered } \\
\text { by rock pile }\end{array}$ & Industrial & Stone & $\begin{array}{c}12.1 \mathrm{~m} \\
\text { circumference }\end{array}$ \\
\hline N4 & $\begin{array}{l}\text { Mineral/Kiln } \\
\text { House }\end{array}$ & 503 & $\begin{array}{l}\text { Stone wall and foundations. } \\
\text { Collapsed rocks are against } \\
\text { north and west walls. East } \\
\text { wall is barely visible. }\end{array}$ & Industrial & Stone & $19.4 \times 10 \mathrm{~m}$ \\
\hline $\mathrm{N} 4$ & No. 4 Shaft & 504 & $\begin{array}{l}\text { flat area and part of uphill } \\
\text { slope near metal hooks in } \\
\text { concrete and barbed wire }\end{array}$ & Industrial & Stone & $4.8 \mathrm{~m}$ diameter \\
\hline $\mathrm{N} 4$ & Waste Rock Piles & 505 & Oval piles of waste rock & Industrial & Stone & Unknown \\
\hline $\mathrm{N} 4$ & Covered Tram Way & 506 & $\begin{array}{l}\text { Level hard-packed pathway } \\
3.5 \mathrm{~m} \text { wide leading from rock } \\
\text { piles to the edge of the bluff. }\end{array}$ & Industrial & Stone & Over $300 \mathrm{~m}$ \\
\hline $\mathrm{N} 4$ & Powder House & 507 & $\begin{array}{l}\text { Powder House wall } \\
\text { foundation, stone, circular, } \\
\text { iron materials (cable, barrel } \\
\text { rings). Possible doorway on } \\
\text { NE side }\end{array}$ & Industrial & Stone & $\begin{array}{l}\text { diameter- } \\
2.7 \mathrm{~m} \text { Wall } \\
\text { Width-.8m } \\
\text { Door Width- } \\
1.8 \mathrm{~m}\end{array}$ \\
\hline $\mathrm{N} 4$ & $\begin{array}{l}\text { C\&H Era } \\
\text { Foundations } \\
\end{array}$ & 508 & $\begin{array}{l}\text { Poured concrete pads with } \\
\text { metal bolts. }\end{array}$ & Industrial & Concrete & $\begin{array}{l}.19 \times 3.69 \mathrm{~m} \\
2.28 \times 2.13 \mathrm{~m} \\
\end{array}$ \\
\hline $\mathrm{N} 4$ & $\begin{array}{l}\text { C\&H Era Cement } \\
\text { Base (near } \\
\text { Powderhouse) }\end{array}$ & 509 & $\begin{array}{l}\text { Calumet \& Hecla era } \\
\text { concrete foundation. Possible } \\
\text { transfer station for electric } \\
\text { power. }\end{array}$ & Industrial & Concrete & $3.75 \times 3.6 \mathrm{~m}$ \\
\hline $\mathrm{N} 4$ & Boarding Houses & 510 & $\begin{array}{l}\text { Two stone foundation wood } \\
\text { boarding homes built in the } \\
1860 \text { 's for workers at the } \\
\text { Howe Shaft. }\end{array}$ & Habitation & Stone & Unknown \\
\hline $\mathrm{N} 4$ & Dam and drain & 511 & $\begin{array}{l}\text { Possible dam and drain } \\
\text { located to the SE of No. } 4 \\
\text { Engine House. Large pipe } \\
\text { and flange preetn. Wire rope } \\
\text { wrapped around tree as well. }\end{array}$ & Industrial & Earth & N/A \\
\hline $\mathrm{N} 4$ & Unknown Structure & 512 & Stone foundation wall & Unknown & Stone & $10 \times 5.25 \mathrm{~m}$ \\
\hline
\end{tabular}




\section{Appendix B:}

\section{List of Features}

\begin{tabular}{|c|c|c|c|c|c|c|}
\hline $\mathrm{N} 4$ & Unknown Structure & 515 & $\begin{array}{l}\text { Possible habitation. Stone } \\
\text { foundation with possible } \\
\text { doorway. }\end{array}$ & Habitation & Stone/Earth & $8.3 \times 4.5 \mathrm{~m}$ \\
\hline $\mathrm{N} 4$ & Well & 516 & Stone lined well. & Habitation & Stone & $\begin{array}{c}1.25 \mathrm{~m} \\
\text { diameter }\end{array}$ \\
\hline $\mathrm{N} 4$ & Exploration Pit & 517 & $\begin{array}{l}\text { Large pit, no foundation } \\
\text { visible. }\end{array}$ & Landscape & Earth & $3.5 \mathrm{~m}$ diameter \\
\hline N4 & Wall & 518 & Long wall. & Habitation & Stone/Earth & $4.4 \mathrm{~m}$ \\
\hline ER & School House & 600 & Not recorded & Cultural & N/A & N/A \\
\hline ER & Odd Fellows Office & 601 & Not recorded & Cultural & N/A & N/A \\
\hline ER & River & 602 & West Branch of Eagle River & Landscape & N/A & N/A \\
\hline ER & Carpentry Shop & 603 & Not recorded & Industrial & N/A & N/A \\
\hline ER & $\begin{array}{l}\text { C\&H Era } \\
\text { Foundation } \\
\end{array}$ & 604 & $\begin{array}{l}\text { Cement slab used to anchor } \\
\text { electric lines? }\end{array}$ & Industrial & Cement & $1 \times 2 \mathrm{~m}$ \\
\hline ER & $\begin{array}{l}\text { Dock at Eagle } \\
\text { River }\end{array}$ & 605 & $\begin{array}{l}\text { Ephemeral remains of dock } \\
\text { used by company to off load } \\
\text { copper. }\end{array}$ & Transportation & N/A & $\mathrm{N} / \mathrm{A}$ \\
\hline ER & Waste Rock Piles & 608 & Large rock piles & Landscape & Stone & N/A \\
\hline ER & Stamp Sands & 609 & Not recorded & Landscape & Earth & N/A \\
\hline WP & Race/Launder & 701 & $\begin{array}{l}.5 \mathrm{~m} \text { wide wood lined } \\
\text { launder for water of } \\
\text { unknown purpose }\end{array}$ & Industrial & Wood & Unknown \\
\hline WP & Dam & 702 & Not recorded & Industrial & $\mathrm{N} / \mathrm{A}$ & N/A \\
\hline WP & $\begin{array}{l}\text { Clerk's Home and } \\
\text { Barn }\end{array}$ & 703 & $\begin{array}{l}\text { Full stone in-ground } \\
\text { basement with steps to } \\
\text { outside. North of basement } \\
\text { is attached on-ground stone } \\
\text { foundation. North and east } \\
\text { of this is depression which } \\
\text { could be for barn. North of } \\
\text { dwelling two large excavated } \\
\text { pits. }\end{array}$ & Habitation & Stone & Unknown \\
\hline WP & $\begin{array}{l}\text { Large Stone } \\
\text { Building below } \\
\text { road }\end{array}$ & 704 & $\begin{array}{l}\text { Two room stone building } \\
\text { foundation located to the } \\
\text { south of the wagon road. }\end{array}$ & Industrial & Stone & $9.9 \times 9.3 \mathrm{~m}$ \\
\hline WP & $\begin{array}{l}\text { west Exploration } \\
\text { Diggings }\end{array}$ & 705 & $\begin{array}{l}\text { Exploration trench going } \\
\text { through the wagon road. } \\
\text { Waste rock pile located at } \\
\text { south end. }\end{array}$ & Landscape & Earth & N/A \\
\hline WP & Depression & 707 & $\begin{array}{l}\text { Large depression with raised } \\
\text { stone foundation. Large } \\
\text { boulders located in center } \\
\text { (fallen down from the } \\
\text { bluff?). }\end{array}$ & Habitation & Stone & $5.5 \times 5.7 \mathrm{~m}$ \\
\hline WP & Berm/tram way & 709 & $\begin{array}{l}\text { Raised platform coming off } \\
\text { of exploration trench. } \\
\text { Extends } 31 \mathrm{~m} \text { at } 5.7 \mathrm{~m} \text { in } \\
\text { width. }\end{array}$ & Landscape & Earth & $31 \times 5.7 \mathrm{~m}$ \\
\hline WP & Stone Wall & 710 & $\begin{array}{l}\text { Foundation wall, possibly } \\
\text { part of a larger structure. }\end{array}$ & Unknown & Stone/Earth & $10 \times 5.1 \mathrm{~m}$ \\
\hline WP & Wagon Road & 711 & $\begin{array}{l}\text { Wagon road leading from } \\
\text { stamp mill to clerk's house. } \\
\text { Also large rock pile pushed } \\
\text { aside to make way for the } \\
\text { road. }\end{array}$ & Transportation & Earth & N/A \\
\hline
\end{tabular}




\section{Appendix B:}

\section{List of Features}

\begin{tabular}{|c|c|c|c|c|c|c|}
\hline EP & Wagon Road & 800 & $\begin{array}{l}\text { Wagon road leading past } \\
\text { machine shop NE toward } \\
\text { cemetery and then Eagle } \\
\text { River. }\end{array}$ & Transportation & Earth & N/A \\
\hline EP & $\begin{array}{l}\text { Possible Powder } \\
\text { House }\end{array}$ & 801 & $\begin{array}{l}\text { Thick walled stone } \\
\text { foundations lying to north of } \\
\text { wagon road. }\end{array}$ & Industrial & Stone & $\begin{array}{l}\text { Outer: } 4.7 \times 4 \mathrm{~m} \text {, } \\
\text { Inner: } 3.7 \times 3 \mathrm{~m}\end{array}$ \\
\hline EP & $\begin{array}{l}\text { Protestant } \\
\text { Cemetery }\end{array}$ & 802 & Cemetery of the wagon Road & Habitation & $\mathrm{N} / \mathrm{A}$ & $\mathrm{N} / \mathrm{A}$ \\
\hline EP & Earthen depression & 803 & $\begin{array}{l}\text { Earthen depression located } \\
2.2 \mathrm{~m} \text { west of feature } 828 \text {. }\end{array}$ & Unknown & Earth & $2.4 \mathrm{~m}$ diameter \\
\hline EP & $\begin{array}{l}\text { Stone building east } \\
\text { of } \\
\text { intersection/Powder } \\
\text { House }\end{array}$ & 804 & $\begin{array}{l}\text { Rectangular stone building } \\
\text { with walls indicative of a } \\
\text { powder house. }\end{array}$ & Industrial & Stone & Unknown \\
\hline EP & Structure-Unknown & 805 & $\begin{array}{l}\text { Rectangular depression in } \\
\text { the ground, no defiant } \\
\text { foundation. }\end{array}$ & Habitation & Earth & $7.7 \times 6.1 \mathrm{~m}$ \\
\hline EP & $\begin{array}{l}\text { east Exploration } \\
\text { Diggings/Shafts }\end{array}$ & 806 & $\begin{array}{l}\text { Large drift/trench dug into } \\
\text { side of bluff along with two, } \\
\text { possibly three exploratory } \\
\text { shafts. }\end{array}$ & Landscape & Earth & Unknown \\
\hline EP & Barn/Stable & 807 & $\begin{array}{l}\text { Overgrown stone foundation } \\
\text { located } 13.3 \mathrm{~m} \text { south of the } \\
\text { wagon road. }\end{array}$ & Habitation & Stone & $15 \times 8.2 \mathrm{~m}$ \\
\hline EP & Dwelling & 808 & $\begin{array}{l}\text { Possible dwelling located } \\
\text { north of wagon road lying } \\
\text { just east of suspected early } \\
\text { powder house. }\end{array}$ & Habitation & Stone & $7 \times 6 \mathrm{~m}$ \\
\hline EP & Exploration Pit & 809 & Exploration pit. & Landscape & Earth & $11.2 \times 6.1 \mathrm{~m}$ \\
\hline EP & Enclosure & 810 & Circular stone structure. & Unknown & Stone & $4.2 \times 4 \mathrm{~m}$ \\
\hline EP & Dwelling & 811 & $\begin{array}{l}\text { Two room stone building. } \\
\text { Possible dwelling. }\end{array}$ & Habitation & Stone & $10 \times 5.3 \mathrm{~m}$ \\
\hline EP & Dwelling & 812 & $\begin{array}{l}\text { Two room stone building. } \\
\text { Possible dwelling. }\end{array}$ & Habitation & Stone & $11 \times 6 \mathrm{~m}$ \\
\hline EP & Dwelling & 813 & One room dwelling. & Habitation & Stone & Unknown \\
\hline EP & Well & 814 & Stone lined well. & Habitation & Stone & $1.3 \mathrm{~m}$ diameter \\
\hline EP & Dwelling & 815 & One room dwelling. & Habitation & Stone & $6 \times 3.7 \mathrm{~m}$ \\
\hline EP & Dwelling & 816 & $\begin{array}{l}\text { One room dwelling. Located } \\
8 \mathrm{~m} \text { east of Feature } 815 \text { and } \\
10 \mathrm{~m} \text { north of wagon road. }\end{array}$ & Habitation & Stone & $5.5 \times 4.6 \mathrm{~m}$ \\
\hline EP & Dwelling & 817 & $\begin{array}{l}\text { One room dwelling with } \\
\text { associated privy. }\end{array}$ & Habitation & Stone & $6.53 \times 5.35 \mathrm{~m}$ \\
\hline EP & Enclosure & 818 & $\begin{array}{l}\text { One room dwelling located } \\
\text { north of wagon road. }\end{array}$ & Habitation & Stone & $4.7 \times 4.5 \mathrm{~m}$ \\
\hline EP & Structure-Unknown & 819 & $\begin{array}{l}\text { One room dwelling located } \\
\text { north of wagon road and east } \\
\text { of cemetery. }\end{array}$ & Habitation & Stone & $7.85 \times 6.2 \mathrm{~m}$ \\
\hline EP & Exploration Trench & 820 & $\begin{array}{l}\text { Exploration trench running } \\
\text { NW-SE near wagon road and } \\
\text { located just east of feature } \\
808 \text {. }\end{array}$ & Landscape & Earth & $10 \times 3.2 \mathrm{~m}$ \\
\hline EP & Spoil Pile & 821 & Waste Rock Pile & Landscape & Earth/Rock & $8.5 \times 12 \mathrm{~m}$ \\
\hline
\end{tabular}




\section{Appendix B:}

\section{List of Features}

\begin{tabular}{|c|c|c|c|c|c|c|}
\hline EP & Exploration Pit & 822 & $\begin{array}{l}\text { Exploration pit located } 6.5 \mathrm{~m} \\
\text { NW of feature } 820 .\end{array}$ & Landscape & Earth & $\begin{array}{c}5.5 \times 5 \mathrm{~m} \\
\text { diameter }\end{array}$ \\
\hline EP & Exploration Pit & 823 & $\begin{array}{l}\text { Exploration pit located } 7 \mathrm{~m} \\
\text { NW of feature } 822 .\end{array}$ & Landscape & Earth & $4.3 \mathrm{~m}$ \\
\hline EP & Garbage Dump & 824 & $\begin{array}{l}\text { south of wagon road, } \\
\text { southwest of feature } 805 . \\
\text { Heavily looted. Bone, } \\
\text { ceramic, glass, metal, etc. }\end{array}$ & Habitation & Other & Unknown \\
\hline EP & Structure-Unknown & 825 & $\begin{array}{l}\text { Stone structure with } \\
\text { depression in center. } \\
\text { Southwest corner most } \\
\text { intact. }\end{array}$ & Unknown & Stone & $7.2 \times 5 \mathrm{~m}$ \\
\hline EP & $\begin{array}{l}\text { Earthen } \\
\text { Depressions }\end{array}$ & 826 & $\begin{array}{l}\text { Round and arc like } \\
\text { depressions located north of } \\
\text { the wagon road. }\end{array}$ & Unknown & Stone/Earth & $2 \mathrm{~m}$ diameter \\
\hline EP & Unknown & 827 & $\begin{array}{l}\text { Round and arc like } \\
\text { depressions located north of } \\
\text { the wagon road } 1 \mathrm{~m} \text { east of } \\
\text { feature } 826 \text {. }\end{array}$ & Unknown & Stone/Earth & $2 \mathrm{~m}$ diameter \\
\hline EP & Unknown & 828 & $\begin{array}{l}\text { Round and arc like } \\
\text { depressions located north of } \\
\text { the wagon road } 2 \mathrm{~m} \text { east of } \\
\text { feature } 827 \text {. }\end{array}$ & Unknown & Stone/Earth & $3.7 \mathrm{~m}$ diameter \\
\hline EP & Unknown & 829 & $\begin{array}{l}\text { Round and arc like } \\
\text { depressions located north of } \\
\text { the wagon road } 2.5 \mathrm{~m} \text { west of } \\
\text { feature } 828 \text {. }\end{array}$ & Unknown & Stone/Earth & Unknown \\
\hline EP & Unknown & 830 & $\begin{array}{l}\text { Round and arc like } \\
\text { depressions located north of } \\
\text { the wagon road } 3.5 \mathrm{~m} \text { east of } \\
\text { feature } 829 \text {. }\end{array}$ & Unknown & Stone/Earth & Unknown \\
\hline CT & $\begin{array}{l}\text { Historical Property } \\
\text { Marker }\end{array}$ & 900 & Forged iron section markers. & Cultural & Metal & N/A \\
\hline $\mathrm{CT}$ & Dwelling & 901 & $\begin{array}{l}\text { Possible dwelling and } \\
\text { associated privy on log cabin } \\
\text { row, located } 30 \mathrm{~m} \text { south of } \\
\text { Methodist Church }\end{array}$ & Habitation & Earth & $8 \times 6 \mathrm{~m}$ \\
\hline $\mathrm{CT}$ & Dwelling & 902 & $\begin{array}{l}\text { Possible dwelling near } \\
\text { Methodist Church, located } \\
\text { on log cabin row. Possible } \\
\text { cellar pit in the corner. }\end{array}$ & Habitation & Earth/Stone & $\begin{array}{c}\text { Outer- } \\
5.5 \times 4.5 \mathrm{~m} \\
\text { Inner- } \\
4.5 \times 3.5 \mathrm{~m} \\
\end{array}$ \\
\hline $\mathrm{CT}$ & Dwelling & 903 & $\begin{array}{l}\text { Possible dwelling 3rd in a } \\
\text { row from Methodist Church, } \\
\text { located on log cabin row. } \\
\text { Possible cellar pit in SW } \\
\text { corner, brick and stones } \\
\text { inside. }\end{array}$ & Habitation & Earth & $4.5 \mathrm{mx} 4 \mathrm{~m}$ \\
\hline $\mathrm{CT}$ & Dwelling & 904 & $\begin{array}{l}\text { Possible dwelling with a } \\
\text { depression inside and } \\
\text { associated privy. Large } \\
\text { looter pits with broken pieces } \\
\text { of pottery, glass, and china. } \\
\text { Located on log cabin row, } \\
\text { near Methodist Church. }\end{array}$ & Habitation & Stone & $\begin{array}{l}\text { Outer- } 6 \times 7 \mathrm{~m} \\
\text { Inner- } 4 \times 5 \mathrm{~m}\end{array}$ \\
\hline $\mathrm{CT}$ & Dwelling & 905 & $\begin{array}{l}\text { Possible dwelling, stone } \\
\text { foundation wall, no privy, } \\
\text { and located on log cabin row, } \\
\text { near the Methodist church }\end{array}$ & Habitation & Stone & $7.8 \times 10.8 \mathrm{~m}$ \\
\hline CT & Dwelling & 906 & $\begin{array}{l}\text { foundation wall with pit at } \\
\text { the south end and in the } \\
\text { center. }\end{array}$ & Habitation & Stone & $8.8 \times 3.2 \mathrm{~m}$ \\
\hline
\end{tabular}




\section{Appendix B:}

\section{List of Features}

\begin{tabular}{|c|c|c|c|c|c|c|}
\hline $\mathrm{CT}$ & Dwelling & 907 & $\begin{array}{l}\text { Possible dwelling, pit } .5 \mathrm{~m} \\
\text { deep inside structure. } \\
\text { Located on log cabin row, } \\
\text { near the Methodist Church. }\end{array}$ & Habitation & Earth & $4 \times 8 m$ \\
\hline $\mathrm{CT}$ & Dwelling & 908 & $\begin{array}{l}\text { Possible dwelling, on log } \\
\text { cabin row, located near the } \\
\text { Methodist Church. }\end{array}$ & Habitation & Earth & $5.5 \times 3.75 \mathrm{~m}$ \\
\hline CT & Dwelling & 909 & $\begin{array}{l}\text { Possible dwelling, on log } \\
\text { cabin row, located near the } \\
\text { Methodist Church. Some } \\
\text { poor rock and brick in the } \\
\text { corners. } 1.5 \mathrm{~m} \text { central pit and } \\
1.5 \mathrm{~m} \text { to a stone lined well. }\end{array}$ & Habitation & $\begin{array}{c}\text { Earth Stone } \\
\text { Brick }\end{array}$ & $5 \times 5 \mathrm{~m}$ \\
\hline $\mathrm{CT}$ & Dwelling & 910 & $\begin{array}{l}\text { Possible dwelling, on log } \\
\text { cabin row, located near the } \\
\text { Methodist Church. Parts of a } \\
\text { jug, stove leg, lock. \& a } \\
\text { bucket found in depression. } \\
\text { Some rock foundation. }\end{array}$ & Habitation & Earth/Stone & $9 \times 9 \mathrm{~m}$ \\
\hline $\mathrm{CT}$ & Dwelling & 911 & $\begin{array}{l}\text { Possible dwelling, on log } \\
\text { cabin row, located near the } \\
\text { Methodist Church. }\end{array}$ & Habitation & Stone & $\begin{array}{l}\text { Outer- } 7 \times 6 \mathrm{~m} \\
\text { Inner- } 6 \times 5 \mathrm{~m}\end{array}$ \\
\hline $\mathrm{CT}$ & Dwelling & 912 & $\begin{array}{l}\text { Possible dwelling, on log } \\
\text { cabin row, located near the } \\
\text { Methodist Church. Many } \\
\text { metal pieces in and around } \\
\text { the structure. }\end{array}$ & Habitation & Stone/Earth & $8 \times 5 \mathrm{~m}$ \\
\hline CT & Dwelling & 913 & $\begin{array}{l}\text { Possible dwelling, on log } \\
\text { cabin row, located near the } \\
\text { Methodist Church. Pit } \\
\text { located inside } 4 \mathrm{~m} \text { in } \\
\text { diameter. }\end{array}$ & Habitation & Stone/Earth & $7 \times 6 \mathrm{~m}$ \\
\hline $\mathrm{CT}$ & Dwelling & 914 & $\begin{array}{l}\text { Possible dwelling, on log } \\
\text { cabin row, located near the } \\
\text { Methodist Church, } \\
\text { surrounded by raised ground } \\
\& \text { some rock. Possible } \\
\text { privy. }\end{array}$ & Habitation & Stone & $6 \times 5.3 \mathrm{~m}$ \\
\hline $\mathrm{CT}$ & Resovoir & 915 & $\begin{array}{l}\text { Three pits located outside } \\
\text { of the structure, timbers in } \\
\mathrm{NW}, \mathrm{E} \text {, and } \mathrm{N} \text { wall, as well } \\
\text { as on the bottom. Small pit } \\
.8 \text {, from } \mathrm{W} \text { wall. }\end{array}$ & Landscape & Earth & $4 \times 8 m$ \\
\hline $\mathrm{CT}$ & Dwelling & 916 & $\begin{array}{l}\text { Possible dwelling, on log } \\
\text { cabin row, located near the } \\
\text { Methodist Church. Rocks } \\
\text { along some walls, looting pit } \\
1.5 \mathrm{~m} \text { from center of east } \\
\text { wall. }\end{array}$ & Habitation & Stone & $6 \times 6.9 \mathrm{~m}$ \\
\hline $\mathrm{CT}$ & Dwelling & 917 & $\begin{array}{l}\text { Possible dwelling, has } \\
\text { central dividing with } \\
\text { deperessions on either side. }\end{array}$ & Habitation & Stone & $8.4 \times 7.7 \mathrm{~m}$ \\
\hline CT & Methodist Church & 918 & $\begin{array}{l}\text { Methodist Church foundation } \\
\text { walls, doorway location is } \\
\text { apparent. }\end{array}$ & Cultural & Stone & $\begin{array}{l}\text { Outer- } \\
10.5 \times 18.4 \mathrm{~m} \\
\text { Inner- } \\
9.9 \times 17.8 \mathrm{~m} \\
\text { Wall Width- } \\
.6 \mathrm{~m}\end{array}$ \\
\hline
\end{tabular}




\section{Appendix B:}

\section{List of Features}

\begin{tabular}{|c|c|c|c|c|c|c|}
\hline CT & Dwelling & 919 & $\begin{array}{l}\text { Stone foundation, pit in the } \\
\text { center. } 45.5 \mathrm{~m} \text { to the } \\
\text { Episcopal Church. }\end{array}$ & Habitation & Stone & $8.5 \times 9.7 \mathrm{~m}$ \\
\hline $\mathrm{CT}$ & Rock Pile & 920 & $\begin{array}{l}\text { Rock pile near Shaft } 1 \text {, rock } \\
\text { pile can be seen in the } \\
\text { historic birdseye view of } \\
\text { Cliffton. }\end{array}$ & Landscape & Rock & $20.5 \times 28 \mathrm{~m}$ \\
\hline $\mathrm{CT}$ & Dwelling & 921 & $\begin{array}{l}\text { Rock foundation found in the } \\
\text { middle of a large wetland. } \\
\text { Warehouse lies } 50 \mathrm{~m} \text { to the } \\
\text { east. }\end{array}$ & Habitation & Stone & $9.8 \times 5.8 \mathrm{~m}$ \\
\hline $\mathrm{CT}$ & Dwelling & 922 & $\begin{array}{l}\text { Rock foundation east of } \\
\text { Warehouse and east of Cliff } \\
\text { Drive. }\end{array}$ & Habitation & Stone & $9.75 \times 8.75 \mathrm{~m}$ \\
\hline CT & Icehouse & 923 & $\begin{array}{l}\text { Stone foundation, } 3 \text { out of } 4 \\
\text { walls intact, east of agents } \\
\text { house, doorway visible on } \\
\text { south wall, possible } \\
\text { solidified cement bags } \\
\text { inside, and a ramp is located } \\
\text { in line with the collapsed } \\
\text { part of the west wall. }\end{array}$ & Industrial & Stone/Mortar & $\begin{array}{l}\text { Outer- } \\
12.3 \times 6.5 \mathrm{~m} \\
\text { Stone Ramp- } \\
6.5 \times 3 \mathrm{~m}\end{array}$ \\
\hline $\mathrm{CT}$ & Dwelling & 924 & $\begin{array}{l}\text { Stone foundation, two deep } \\
\text { looters pit in structure, NE of } \\
\text { 923, charred floorboards in a } \\
\text { pile next to structure. }\end{array}$ & Habitation & Stone/Mortar & $9.61 \times 4.25 \mathrm{~m}$ \\
\hline $\mathrm{CT}$ & Dwelling & 925 & $\begin{array}{l}\text { Rock foundation in open } \\
\text { grassy meadow. Definite } \\
\text { rock walls. Two obvious } \\
\text { looter pits. }\end{array}$ & Habitation & Stone & $\begin{array}{c}\text { Outer- } \\
9.6 \times 4.6 \mathrm{~m} \\
\text { Wall Width- } \\
.45 \mathrm{~m} \\
\end{array}$ \\
\hline $\mathrm{CT}$ & Dwelling & 926 & $\begin{array}{l}\text { NW from } 925, \text { stone } \\
\text { foundation earth and plant } \\
\text { covered, brick slump in } \\
\text { center of north Wall. }\end{array}$ & Habitation & Stone & $8.9 \times 4.8 \mathrm{~m}$ \\
\hline $\mathrm{CT}$ & Dwelling & 927 & $\begin{array}{l}\text { Rock foundation, north of } \\
928, \text { and rose bushes nearby. }\end{array}$ & Habitation & Stone & $9.8 \times 8.5 \mathrm{~m}$ \\
\hline CT & Dwelling & 928 & Stone foundation & Habitation & Stone & $9.55 \times 7.1 \mathrm{~m}$ \\
\hline $\mathrm{CT}$ & $\begin{array}{l}\text { Historic Property } \\
\text { Marker }\end{array}$ & 929 & $\begin{array}{l}\text { Historic marker due east of } \\
928 \text {, township } 58 \text {, range } 32 \text {. }\end{array}$ & Cultural & Metal & Unknown \\
\hline $\mathrm{CT}$ & Dwelling & 930 & Stone foundation & Habitation & Stone & $9 \times 8.6 \mathrm{~m}$ \\
\hline $\mathrm{CT}$ & Dwelling & 931 & $\begin{array}{l}\text { Stone foundation, earthen } \\
\text { cover, north of } 933\end{array}$ & Habitation & Stone & $9.975 \times 8.75 \mathrm{~m}$ \\
\hline $\mathrm{CT}$ & Dwelling & 932 & Stone foundation, SW of 931 & Habitation & Stone & $9 \times 5 \mathrm{~m}$ \\
\hline $\mathrm{CT}$ & Dwelling & 933 & $\begin{array}{l}\text { Stone foundation, SW of } \\
932, \text { near the old railroad ( } \\
\text { the road we drive on). }\end{array}$ & Habitation & Stone & $9.2 \times 6.5 \mathrm{~m}$ \\
\hline CT & Dwelling & 934 & $\begin{array}{l}\text { Stone foundation, west of } \\
933\end{array}$ & Habitation & Stone & $7.7 \times 7.2 \mathrm{~m}$ \\
\hline CT & Dwelling & 935 & $\begin{array}{l}\text { Stone stacked wall, south of } \\
934, \text { north of the railroad. }\end{array}$ & Habitation & Stone & $\begin{array}{l}\text { Stone wall- } \\
4.7 \mathrm{~m} \text { Wall }\end{array}$ \\
\hline
\end{tabular}




\section{Appendix B:}

\section{List of Features}

\begin{tabular}{|c|c|c|c|c|c|c|}
\hline & & & & & & width-. $4 \mathrm{~m}$ \\
\hline $\mathrm{CT}$ & Dwelling & 936 & $\begin{array}{l}\text { Partial stone foundation, } \\
\text { building is on the } 1913 \\
\text { blueprint, weirdly oriented. } \\
\text { Very close to Cliff Drive. }\end{array}$ & Habitation & Stone & $12.5 \times 4.5 \mathrm{~m}$ \\
\hline $\mathrm{CT}$ & Dwelling & 937 & $\begin{array}{l}\text { Stone foundation, glass } \\
\text { bottle bites, iron scraps on } \\
1913 \text { C\&H foundation, cellar } \\
\text { door visible, ledge on the } \\
\text { inside of the building, wall } \\
\text { bisects two separate rooms. }\end{array}$ & Habitation & Stone & $11.5 \times 6.3 \mathrm{~m}$ \\
\hline $\mathrm{CT}$ & Dwelling & 938 & $\begin{array}{l}\text { A fairly deep subterranean } \\
\text { dwelling with adjacent flat, } \\
\text { no structure uniqueness } \\
\text { remains. }\end{array}$ & Habitation & Earth/Stone & $7 \times 3.5 \mathrm{~m}$ \\
\hline $\mathrm{CT}$ & Dwelling & 939 & $\begin{array}{l}\text { Large pit which is oblong. } \\
\text { There is a stone foundation } \\
\text { visible around the pit. }\end{array}$ & Habitation & Stone & $7.9 \times 9.59 \mathrm{~m}$ \\
\hline $\mathrm{CT}$ & Platform & 940 & $\begin{array}{l}\text { Small square shaped dry laid } \\
\text { cobble platform. Approx. } 5 \mathrm{~m} \\
\text { south of Cliff Drive. }\end{array}$ & Landscape & Stone & $3 \times 3 \mathrm{~m}$ \\
\hline $\mathrm{CT}$ & Dwelling & 941 & $\begin{array}{l}\text { Stone foundation w/ an } \\
\text { extension of } 3.5 \text { by } 5.6 \mathrm{~m} \text { off } \\
\text { east wall. } 18.5 \mathrm{~m} \text { from } 939.3 \\
\text { pits, iron stove piece and iron } \\
\text { wire. }\end{array}$ & Habitation & Stone & $14.6 \times 9 \mathrm{~m}$ \\
\hline $\mathrm{CT}$ & Dwelling & 942 & Circular stone mound. & Cultural & Stone/Earth & $\begin{array}{l}2.4 \mathrm{~m} \text { in } \\
\text { diameter }\end{array}$ \\
\hline $\mathrm{CT}$ & Dwelling & 943 & $\begin{array}{l}\text { Small collapsed dry laid } \\
\text { some wall structure. } \\
\text { south/east walls have some } \\
\text { integrity. Middle is } \\
\text { depressed \& an adjacent pit } \\
\text { is located to the east. An } \\
\text { additional small rock } \\
\text { pile/platform }(944) \text { is to the } \\
\text { north of the structure about } \\
5 \mathrm{~m} \text {. Structure is south of } \\
\text { Cliff Drive by } 1 \mathrm{~m} \text {. }\end{array}$ & Habitation & Stone & $5.1 \times 5.25 \mathrm{~m}$ \\
\hline $\mathrm{CT}$ & Dwelling & 944 & Circular stone mound. & Cultural & Stone & $\begin{array}{l}1.95 \mathrm{~m} \text { in } \\
\text { diameter }\end{array}$ \\
\hline $\mathrm{CT}$ & Dwelling & 945 & $\begin{array}{l}\text { Stone foundation for a } \\
\text { dwelling, seems to be a } \\
\text { division separating the east } \\
\text { and west halves of the } \\
\text { building. Ground around } \\
\text { walls has been dug up. }\end{array}$ & Habitation & Stone & $6.4 \times 9.3 \mathrm{~m}$ \\
\hline $\mathrm{CT}$ & Dwelling & 946 & $\begin{array}{l}\text { Circular mound- no stone } \\
\text { showing- to the north side of } \\
945 . \text { In row with other stone } \\
\text { mounds on north side of } \\
\text { structures on the south side } \\
\text { of Cliff Drive. }\end{array}$ & Landscape & Earth & $2 \times 2 \mathrm{~m}$ \\
\hline $\mathrm{CT}$ & Dwelling & 947 & $\begin{array}{l}\text { A small hand laid rock } \\
\text { platform/pile just south of } \\
\text { Cliff Drive. }\end{array}$ & Landscape & Stone & $2.5 \times 2.7 \mathrm{~m}$ \\
\hline
\end{tabular}




\section{Appendix B:}

\section{List of Features}

\begin{tabular}{|c|c|c|c|c|c|c|}
\hline $\mathrm{CT}$ & Dwelling & 948 & $\begin{array}{l}\text { Slightly rectangular stone } \\
\text { foundation with stone } \\
\text { platform in the middle and a } \\
\text { well lined with stone to the } \\
\text { north. The well and the } \\
\text { structure are south of Cliff } \\
\text { Drive. }\end{array}$ & Habitation & Stone & $10 \times 9 \mathrm{~m}$ \\
\hline $\mathrm{CT}$ & Dwelling & 949 & $\begin{array}{l}\text { A pit in the center of } \\
\text { mounded walls, some stone } \\
\text { foundation visible. Slightly } \\
\text { up hill from other structures. } \\
\text { Pit is off of north wall. }\end{array}$ & Habitation & Stone & $\begin{array}{l}\text { Outer- } \\
4.8 \times 5.2 \mathrm{~m} \text { Pit- } \\
3 \times 1.5 \mathrm{~m}\end{array}$ \\
\hline $\mathrm{CT}$ & Dwelling & 951 & $\begin{array}{l}\text { Depression in the ground. No } \\
\text { obvious walls around it. }\end{array}$ & Habitation & Earth & $\begin{array}{l}\text { Inner- } \\
3.3 \times 6.1 \mathrm{~m}\end{array}$ \\
\hline $\mathrm{CT}$ & Dwelling & 952 & $\begin{array}{l}\text { Small pit, no structural } \\
\text { features. }\end{array}$ & Landscape & Earth & $3.5 \times 3.0 \mathrm{~m}$ \\
\hline CT & Dwelling & 953 & $\begin{array}{l}\text { Collapsed structural remains, } \\
\text { sub-surface is filled with } \\
\text { Modern historic }\end{array}$ & Habitation & Earth & $\begin{array}{l}\text { Outer- } 5.3 \mathrm{~m} \\
\text { wide } \\
\text { Pit- } 1.2 \mathrm{~m} \text { in } \\
\text { diameter. }\end{array}$ \\
\hline $\mathrm{CT}$ & Dwelling & 954 & $\begin{array}{l}\text { A small featureless pit, dug } \\
\text { into the side of a hill. A } \\
\text { small dirt trail skirts the edge } \\
\text { of it's north \& east sides. }\end{array}$ & Landscape & Earth & $5.3 \times 5.1 \mathrm{~m}$ \\
\hline CT & Dwelling & 955 & $\begin{array}{l}\text { N Side of Cliff drive, stone } \\
\text { foundation, iron dresser } \\
\text { handle near NW corner, } \\
18.5 \mathrm{~m} \text { to Cliff Drive. }\end{array}$ & Habitation & Stone & $4.9 \times 6.5 \mathrm{~m}$ \\
\hline CT & Dwelling & 956 & $\begin{array}{l}\text { Depression \& raised earth, } \\
\text { presumably where walls } \\
\text { were, indicating a building. }\end{array}$ & Habitation & Earth & $6 \times 7 \mathrm{~m}$ \\
\hline $\mathrm{CT}$ & Dwelling & 957 & $\begin{array}{l}\text { Mound indicating walls of a } \\
\text { structure, center of feature is } \\
\text { a pit. }\end{array}$ & Habitation & Stone & $4.9 \times 7.3 \mathrm{~m}$ \\
\hline CT & Dwelling & 958 & $\begin{array}{l}\text { Stone foundation, north of } \\
\text { Cliff Drive. }\end{array}$ & Habitation & Stone & $7 \times 5.7 \mathrm{~m}$ \\
\hline $\mathrm{CT}$ & Dwelling & 959 & $\begin{array}{l}\text { Raised earth \& depression } \\
\text { indicating a dwelling/living } \\
\text { quarters, no stone wall } \\
\text { visible, presence of berm } \\
\text { between pits }(2.5 \mathrm{~m}) . \\
\end{array}$ & Habitation & Stone & $4.5 \times 3.5 \mathrm{~m}$ \\
\hline $\mathrm{CT}$ & Dwelling & 960 & $\begin{array}{l}\text { Two small pits separated by } \\
\text { a berm, both are built into a } \\
\text { small hillside and have } \\
\text { trenches running out of their } \\
\text { ends. The SE pit has been } \\
\text { recently looted. }\end{array}$ & Habitation & Earth & $\begin{array}{l}2.6 \times 2.4 \mathrm{~m} \\
3.3 \times 3.4 \mathrm{~m} \\
\end{array}$ \\
\hline $\mathrm{CT}$ & Structure-Unknown & 961 & $\begin{array}{l}\text { Stone foundation with } \\
\text { possible door on the } \\
\text { northeast wall, two interior } \\
\text { stone structures-possibly roof } \\
\text { supports, south of Cliff } \\
\text { Drive, one roof support(?) } \\
\text { touches the northeast wall } \\
\text { about } 4 \mathrm{~m} \text { south of the door. }\end{array}$ & Unknown & Stone & $14.7 \times 8.7 \mathrm{~m}$ \\
\hline
\end{tabular}




\section{Appendix B:}

\section{List of Features}

\begin{tabular}{|c|c|c|c|c|c|c|}
\hline CT & Dwelling & 962 & $\begin{array}{l}\text { Earth and stone roughly } \\
\text { rectangular structure with a } \\
\text { pit in center and no clear } \\
\text { corners or exposed walls } \\
\text { present, pit northeast of the } \\
\text { main structure, entire } \\
\text { complex north of tour trail. }\end{array}$ & Habitation & Stone/Earth & $6.5 \times 6.4 \mathrm{~m}$ \\
\hline $\mathrm{CT}$ & Dwelling & 963 & $\begin{array}{l}\text { north of tour trail and west of } \\
962, \text { stone and earth } \\
\text { rectangular structure with pit } \\
\text { in the west side of the } \\
\text { building. }\end{array}$ & Habitation & Stone/Earth & $7.7 \times 6 \mathrm{~m}$ \\
\hline CT & Dwelling & 964 & $\begin{array}{l}\text { Rectangular stone and earth } \\
\text { structure with looters pit on } \\
\text { the eastern side of the } \\
\text { interior of the structure, pile } \\
\text { of fill from the looters pit on } \\
\text { the southeast wall of the } \\
\text { structure. }\end{array}$ & Habitation & Stone/Earth & $6.8 \times 5.3 \mathrm{~m}$ \\
\hline $\mathrm{CT}$ & Dwelling & 965 & $\begin{array}{l}\text { Rectangular stone and earth } \\
\text { structure with a pit in the } \\
\text { center, south of the tour trail } \\
\text { and } 963 \text {. }\end{array}$ & Habitation & Stone/Earth & $8 \times 8 m$ \\
\hline $\mathrm{CT}$ & Dwelling & 966 & $\begin{array}{l}\text { Stone and earth rectangular } \\
\text { structure with a pit in the } \\
\text { center, north of the tour trail, } \\
\text { northwest of CT } 965, \text { no } \\
\text { clear corners or walls. }\end{array}$ & Habitation & Stone/Earth & $6.8 \times 5 \mathrm{~m}$ \\
\hline $\mathrm{CT}$ & Structure-Unknown & 967 & $\begin{array}{l}\text { Shallow oval depression in } \\
\text { the earth, south of the tour } \\
\text { trail, and east of } 968 \text {. }\end{array}$ & Unknown & Earth & $4 \times 3.1 \mathrm{~m}$ \\
\hline $\mathrm{CT}$ & Dwelling & 968 & $\begin{array}{l}\text { south side of the tour trail, } \\
\text { southwest of } 966, \text { square } \\
\text { stone, and earth structure } \\
\text { possibly a dwelling with a pit } \\
\text { to the northwest and a } \\
\text { possible wall to the east. }\end{array}$ & Habitation & Stone/Earth & $4.2 \times 4.2 \mathrm{~m}$ \\
\hline $\mathrm{CT}$ & Structure-Unknown & 969 & $\begin{array}{l}\text { Stone wall south of tour trail, } \\
\text { north of pit with path sloping } \\
\text { down hill, east of } 968 \text {. }\end{array}$ & Unknown & Stone/Earth & $\begin{array}{c}5.4 \mathrm{~m} \text { in } \\
\text { diameter }\end{array}$ \\
\hline $\mathrm{CT}$ & Dwelling & 970 & $\begin{array}{l}\text { west of path, square stone } \\
\text { foundation with pit in the } \\
\text { middle south of } 979 .\end{array}$ & Habitation & Stone/Earth & $4.2 \times 3.8 \mathrm{~m}$ \\
\hline CT & Dwelling & 971 & $\begin{array}{l}\text { Rectangular stone and earth } \\
\text { structure with a pit on the } \\
\text { south inside part of the } \\
\text { structure, east of tour trail. }\end{array}$ & Habitation & Stone/Earth & $6.9 \times 6.2 \mathrm{~m}$ \\
\hline $\mathrm{CT}$ & Dwelling & 972 & $\begin{array}{l}\text { Square stone and earth } \\
\text { structure with a pit inside, } \\
\text { east of the trail, south of } 971 \text {. }\end{array}$ & Habitation & Stone/Earth & $5.8 \times 4.2 \mathrm{~m}$ \\
\hline $\mathrm{CT}$ & Structure-Unknown & 973 & $\begin{array}{l}\text { Stone and earth structure } \\
\text { with shallow pit in center } \\
\text { and rocky pit to the east, the } \\
\text { whole structure is located to } \\
\text { the east of the tour trail. }\end{array}$ & Unknown & Stone/Earth & $7.2 \times 6.6 \mathrm{~m}$ \\
\hline CT & Pump House & 974 & $\begin{array}{l}\text { Slopping earthen hillside to } \\
\text { drain trench with metal pip }\end{array}$ & Industrial & Stone/Earth & \\
\hline
\end{tabular}




\section{Appendix B:}

\section{List of Features}

\begin{tabular}{|c|c|c|c|c|c|c|}
\hline & & & $\begin{array}{l}\text { over rock wall, west of tour } \\
\text { trail. }\end{array}$ & & & \\
\hline CT & Dwelling & 975 & $\begin{array}{l}\text { Earth and stone structure } \\
\text { with pit in the middle, west } \\
\text { of the tour trail. }\end{array}$ & Habitation & Stone/Earth & $6.9 \times 5.7 \mathrm{~m}$ \\
\hline CT & Exploration Pit & 976 & $\begin{array}{l}\text { Deep earthen pit, north of } \\
975\end{array}$ & Landscape & Earth & $\begin{array}{l}5.2 \mathrm{~m} \text { in } \\
\text { diameter }\end{array}$ \\
\hline CT & Exploration Pit & 977 & Earthen pit, west of tour trail. & Landscape & Earth & $4.6 \times 4 \mathrm{~m}$ \\
\hline CT & Exploration Pits & 978 & $\begin{array}{l}\text { Series of three pits, west of } \\
\text { tour trail }\end{array}$ & Landscape & Earth & $\begin{array}{c}1 \mathrm{st} \text { pit- } \\
4.3 \times 3.7 \mathrm{~m} 2 \mathrm{nd} \\
\text { pit- } 1.7 \times 2 \mathrm{~m} \\
3 \text { rd pit- } 1.4 \mathrm{~m} \\
\text { diameter } \\
\end{array}$ \\
\hline СT & Dwelling & 979 & $\begin{array}{l}\text { Stone and earthen structure, } \\
\text { west of tour trail. }\end{array}$ & Habitation & Stone/Earth & $5.65 \times 5.5 \mathrm{~m}$ \\
\hline CT & Dwelling & 980 & $\begin{array}{l}\text { On the west side of the trail, } \\
\text { large earthen pit with some } \\
\text { rock walls. }\end{array}$ & Habitation & Stone/Earth & $7.9 \times 4.3 \mathrm{~m}$ \\
\hline CT & Rock Pile & 981 & $\begin{array}{l}\text { Large rock pile southwest of } \\
\text { CT } 974 \text {, south of/lines up } \\
\text { with the Avery shaft. }\end{array}$ & Landscape & Rock & \\
\hline CT & $\begin{array}{l}\text { C\&H Era Cement } \\
\text { Base }\end{array}$ & 982 & $\begin{array}{l}\text { Trapezoidal concrete } \\
\text { structure, located south of } \\
\text { CT } 981 \text {, two metal bolts on } \\
\text { top and three metal bolts on } \\
\text { the backside. }\end{array}$ & Industrial & Concrete & $3 \times 1.7 \mathrm{~m}$ \\
\hline CT & $\begin{array}{l}\text { C\&H Era Cement } \\
\text { Base and a stone } \\
\text { platform }\end{array}$ & 983 & $\begin{array}{l}\text { Stone square platform, } \\
\text { concrete platform, and } \\
\text { concrete pad, multiple metal } \\
\text { bolts on both platforms, } \\
\text { south of CT } 982 \text {. }\end{array}$ & Industrial & Concrete/Stone & $\begin{array}{l}\text { Concrete } \\
\text { Platform- } \\
3.8 \times 1.2 \mathrm{~m} \\
\text { Stone } \\
\text { Platform- } \\
3.7 \times 3.8 \mathrm{~m} \\
\text { Concrete Pad- } \\
5.1 \times 3.27 \mathrm{~m} \\
\end{array}$ \\
\hline CT & Shaft Number 4 & 984 & $\begin{array}{l}\text { U-shaped stone and earthen } \\
\text { structure with oval pit behind } \\
\text { it to the south, south of } 983\end{array}$ & Industrial & Stone/Earth & $14 \times 6.9 \mathrm{~m}$ \\
\hline СT & $\begin{array}{l}\text { Superintendents } \\
\text { House }\end{array}$ & 985 & $\begin{array}{l}\text { Large stone foundations still } \\
\text { fairly intact, but with some } \\
\text { toppling \& overgrowth. Main } \\
\text { structure has two stone } \\
\text { pillars. Ground level of the } \\
\text { structure has two unknown } \\
\text { stone feature as well. To the } \\
\text { west there is a possible privy, } \\
\text { almost a meter deep, and } \\
\text { another large pit labeled } \\
\text { "septic" and has a ditch } \\
\text { going N/S off the southeast } \\
\text { corner. }\end{array}$ & Habitation & Stone & $17.65 \times 9.3 \mathrm{~m}$ \\
\hline CT & Warehouse & 986 & $\begin{array}{l}\text { Rectangular stone structure, } \\
\text { mostly intact but west wall is } \\
\text { falling into the building, } \\
\text { corners on south wall are } \\
\text { crumbly, Cliff Drive is to the } \\
\text { northwest. }\end{array}$ & Industrial & Stone & $21 \times 9.8 \mathrm{~m}$ \\
\hline СT & Catholic Church & 987 & $\begin{array}{l}\text { The SE corner contains a } \\
\text { cellar, north one is an } \\
\text { exposed stone wall, } \\
4.6 \times 3.85 \mathrm{~m} \text {, pit is } .5 \mathrm{~m} \text { in }\end{array}$ & Cultural & Stone & $18.8 \times 8 \mathrm{~m}$ \\
\hline
\end{tabular}




\section{Appendix B:}

\section{List of Features}

\begin{tabular}{|c|c|c|c|c|c|c|}
\hline & & & $\begin{array}{l}\text { depth, width of the wall is } \\
.58 \mathrm{~m} \text {, west and north walls } \\
\text { are mostly intact. east wall } \\
\text { not visible. }\end{array}$ & & & \\
\hline $\mathrm{CT}$ & Episcopal Church. & 988 & $\begin{array}{l}\text { Large stone foundation, four } \\
\text { stone pillar mounts inside. }\end{array}$ & Cultural & Stone/Wood & $10 \times 8.5 \mathrm{~m}$ \\
\hline $\mathrm{CT}$ & Dwelling & 989 & $\begin{array}{l}\text { Depression with poor rock } \\
\text { and brick, near the Methodist } \\
\text { Church. }\end{array}$ & Habitation & Stone & $6.7 \times 5.2 \mathrm{~m}$ \\
\hline $\mathrm{CT}$ & Dwelling & 990 & $\begin{array}{l}\text { A large pit SW of CT- } 989 \& \\
\text { S of the railroad. Timbers } \\
\text { located inside it. }\end{array}$ & Habitation & Earth/Wood & $2.7 \mathrm{~m}$ diameter \\
\hline $\mathrm{CT}$ & Hoist House & 991 & $\begin{array}{l}\text { Stone foundations- possibly } \\
\text { associated with the Number } \\
2 \text { shaft. }\end{array}$ & Industrial & Stone & $10.2 \times 7.1$ \\
\hline $\mathrm{CT}$ & Structure-Unknown & 992 & $\begin{array}{l}\text { Depression, possible wall } \\
\text { foundation. }\end{array}$ & Unknown & Stone/Earth & $5.7 \mathrm{~m}$ diameter \\
\hline CT & Exploration Pit & 993 & $\begin{array}{l}\text { Pit partially surrounded by } \\
\text { berm. }\end{array}$ & Landscape & Earth & $\begin{array}{c}\text { 3.6m diameter } \\
\text { Berm Width- } \\
2 \mathrm{~m}\end{array}$ \\
\hline $\mathrm{CT}$ & Exploration Pit & 994 & $\begin{array}{l}\text { Mound with large } \\
\text { depression. }\end{array}$ & Landscape & Earth & $3.8 \mathrm{~m}$ diameter \\
\hline $\mathrm{CT}$ & Shaft Number 3 & 995 & $\begin{array}{l}\text { Shaft and shaft house, } \\
\text { surrounded by barbed wire, } \\
\text { long ditch within walls }\end{array}$ & Industrial & Stone & $24.4 \times 18.6 \mathrm{~m}$ \\
\hline $\mathrm{CT}$ & Steam Stack & 996 & $\begin{array}{l}\text { Steam stack mostly } \\
\text { collapsed, open flew still } \\
\text { there. }\end{array}$ & Industrial & Stone & $\begin{array}{l}15 \mathrm{~m} \text { in } \\
\text { circumference }\end{array}$ \\
\hline $\mathrm{CT}$ & Pit and Trench & 997 & $\begin{array}{l}\text { A deep pit with adjoining } \\
\text { trench which runs south. }\end{array}$ & Industrial & Earth & $\begin{array}{c}6 \mathrm{~m} \text { in } \\
\text { diameter }\end{array}$ \\
\hline $\mathrm{CT}$ & Unknown Structure & 998 & $\begin{array}{l}\text { Depression indicating } \\
\text { surface structure. }\end{array}$ & Unknown & Earth & $15.2 \times 4.6 \mathrm{~m}$ \\
\hline $\mathrm{CT}$ & $\begin{array}{l}\text { Engine/Boiler } \\
\text { House }\end{array}$ & 999 & $\begin{array}{l}\text { Flu visible, leads to stack. } \\
\text { Has two distinct rooms and } \\
\text { possible engine mounts. }\end{array}$ & Industrial & Stone & $15 \times 14 \mathrm{~m}$ \\
\hline $\mathrm{CT}$ & Unknown Structure & 1000 & $\begin{array}{l}\text { Round stone structure, NW } \\
\text { of } 1001 \text {, east side trench is } \\
\text { falling out. }\end{array}$ & Industrial & Stone & $\begin{array}{l}2.8 \mathrm{~m} \text { in } \\
\text { diameter }\end{array}$ \\
\hline $\mathrm{CT}$ & Unknown Structure & 1001 & $\begin{array}{l}\text { Rectangular stone structure, } \\
\text { interior wall comes off of the } \\
\text { middle wall and runs }\end{array}$ & Industrial & Stone & $4.2 \times 4 \mathrm{~m}$ \\
\hline
\end{tabular}




\section{Appendix B:}

\section{List of Features}

\begin{tabular}{|c|c|c|c|c|c|c|}
\hline & & & $\begin{array}{l}\text { partway through the building } \\
\text { parallel to exterior west ad } \\
\text { east Wall }\end{array}$ & & & \\
\hline $\mathrm{CT}$ & Machine Mount & 1002 & $\begin{array}{l}\text { Iron bolt with some wood } \\
\text { shims and one with a square } \\
\text { nut, on a stone pad. }\end{array}$ & Industrial & Stone/Wood & $3.45 \times 3.2 \mathrm{~m}$ \\
\hline $\mathrm{CT}$ & Unknown Structure & 1003 & $\begin{array}{l}\text { Nearly square building } \\
\text { foundation with inner wall } \\
\text { forming room. There are } \\
\text { several ditches (looter's pits) } \\
\text { nearby. Building interior } \\
\text { very overgrown. }\end{array}$ & Unknown & Stone & $9.9 \times 10 \mathrm{~m}$ \\
\hline CT & Dwelling & 1004 & $\begin{array}{l}\text { Possible dwelling, southeast } \\
\text { of } 922,3 \text { looting pits behind } \\
\text { the south wall, walls mostly } \\
\text { covered with earth and } \\
\text { plants, rose bushes and apple } \\
\text { trees nearby }\end{array}$ & Habitation & Stone & $9.9 \times 5 \mathrm{~m}$ \\
\hline CT & Shaft No. 2 & 1005 & $\begin{array}{l}\text { shaft in stone structure, south } \\
\text { of railroad, north and south } \\
\text { walls are more intact but } \\
\text { west and east are falling in, } \\
\text { northeast corner fairly intact, } \\
\text { structure and shaft are } \\
\text { covered with earth and plants }\end{array}$ & Industrial & Stone & $10.5 \times 8.1 \mathrm{~m}$ \\
\hline
\end{tabular}

